El Jurado designado por la Comisión del Posgrdo en Biologia Experimental de la División de Ciencias Biológicas y de la Salud de la Universidad Autónoma Metropolitana Iztapalapa, aprobó la tesis titulada:

\title{
ANÁLISIS MOLECULAR DEL TIPO DE MUERTE CELULAR INDUCIDO POR LA TERAPIA COADYUDANTE: METFORMINA Y EL OXAMATO DE SODIO COMO INHIBIDORES DE la vía mTOR Y LA GLUCÓLISIS EN UN MODELO CELULAR TRIPLE NEGATIVO DE CÁNCER DE MAMA
}

Que presentó:

M. en BE. Verónica García Castillo

El dia 11de Junio del 2018.

JURADO:

1. Dra. Ma. Concepción Gutiérrez Ruiz:

2. Dr. R. Eduardo López Umutia:

3. Dra. Verónica Souza Arroyo:

4. Dra. Gabriela Figueroa González:

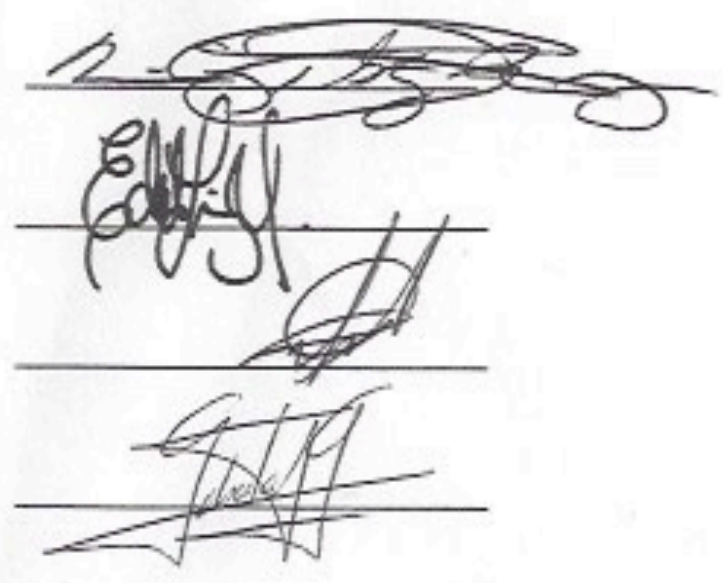




\section{UNIVERSIDAD AUTÓNOMA METROPOLITANA}

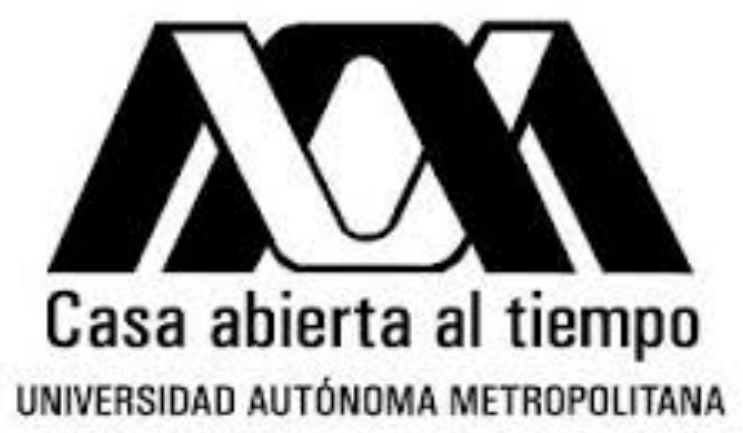

TESIS

ANÁLISIS MOLECULAR DEL TIPO DE MUERTE CELULAR INDUCIDO POR LA TERAPIA COADYUDANTE: METFORMINA Y EL OXAMATO DE SODIO COMO INHIBIDORES DE la vía TTOR Y LA GLUCÓLISIS EN UN MODELO CELULAR TRIPLE NEGATIVO DE CÁNCER DE MAMA

Que para obtener el grado de

Doctora en Biología Experimental

PRESENTA

Verónica García Castillo

Comité tutoral:

1. Dr. Luis Enrique Gómez Quiroz.

2. Dr. Carlos Pérez Plasencia.

3. Dra. Nadia J. Jacobo Herrera.

Junio del 2018. 


\section{AGRADECIMIENTOS A CUERPOS ACADÉMICOS Y FINACIAMIENTO}

“El Programa de Doctorado en Biología Experimental de la Universidad Autónoma Metropolitana pertenece al Programa Nacional de Posgrados de Calidad (PNPC) del CONACYT, registro 001482, en el Nivel Consolidado, y cuenta con apoyo del mismo Consejo, clave DAFCYT-2003IDPTNNN0020.

Durante el desarrollo de este proyecto de Tesis la M. en BE. VERÓNICA GARCÍA CASTILLO fue depositaria de la Beca CONACyT con número de registro: 248822. La beca para realizar sus estudios de Doctorado fue otorgada durante el periodo de: Enero del 2014 a Diciembre de 2017. 
El Jurado designado por la Comisión del Posgrdo en Biología Experimental de la División de Ciencias Biológicas y de la Salud de la Universidad Autónoma Metropolitana Iztapalapa, aprobó la tesis titulada:

\section{ANÁLISIS MOLECULAR DEL TIPO DE MUERTE CELULAR INDUCIDO POR LA TERAPIA COADYUDANTE: METFORMINA Y EL OXAMATO DE SODIO COMO INHIBIDORES DE la vía mTOR Y LA GLUCÓLISIS EN UN MODELO CELULAR TRIPLE NEGATIVO DE CÁNCER DE MAMA}

Que presentó:

M. en BE. Verónica García Castillo

El día 11 de Junio del 2018.

\section{JURADO:}

1. Dra. Ma. Concepción Gutiérrez Ruíz:

2. Dr. R. Eduardo López Urrutia:

3. Dra. Verónica Souza Arroyo:

4. Dra. Gabriela Figueroa González: 


\section{COMITÉ TUTORAL}

\section{Co-Director:}

\section{Dr. Luis Enrique Gómez Quiroz}

Profesor Investigador Titular "C"

Departamento: Ciencias Biológicas y de la Salud.

Lab. de Toxicología Celular Hepática.

Adscripción: Universidad Autónoma Metropolitana-Iztapalapa

legq@xanum.uam.mx

\section{Co-Director:}

2. Dr. Carlos Pérez Plasencia.

Investigador en Ciencias Médicas

Laboratorio de Genómica Funcional

Adscripción: Instituto Nacional de Cancerología (InCaN)

SIN: III

carlos.pplas@gmail.com

\section{Asesora:}

3. Dra. Nadia J. Jacobo Herrera. Adscripción:

Investigadora en Ciencias Médicas

Unidad de Bioquímica

Adscripción: Instituto Nacional de Ciencias Médicas y la Nutrición (INCMN SZ) nadia.jacobo@gmail.com 


\section{AGRADECIMIENTOS AL COMITÉ TUTORAL}

Agradezco el apoyo fundamental de mi distinguido Comité Tutoral para el desarrollo de éste proyecto: Dr. Carlos Pérez-Plasencia, Dr. Luis E. Gómez Quiroz y la Dra. Nadia J. Jacobo Herrera.

De manera particular agradezco al Dr. Carlos Pérez-Plasencia por brindarme un espacio en su grupo de trabajo y proporcionarme todas las herramientas necesarias para concretar exitosamente cada experimento y por todas sus exigencias que lograron hacerme crecer profesionalmente cada día.

A la Dra. Nadia J. Jacobo Herrera por su apoyo, asesoría y confianza incondicional; quien siempre estuvo pendiente de mí y proporcionarme todo lo necesario para culminar exitosamente éste proyecto.

Al Dr. Luis E. Gómez Quiroz quien siempre estuvo pendiente del desarrollo de éste proyecto; agradezco infinitamente su asesoria, sus consejos y su dedicación en mi formación académica.

Al Dr. R. Eduardo López Urrutia por su asesoría y apoyo durante el escrito de esta tesis y en la fase experimental.

Al laboratorio 11 de la Unidad de Biomedicina (UBIMED) en la Facultad de Estudios Superiores Iztacala (FES-I); UNAM; donde tuve el espacio y la infraestructura para materializar éste proyecto. 


\section{RESUMEN}

La quimioterapia es la principal estrategia para el tratamiento sistémico del cáncer de mama triple negativo (CaMa TN), el cual es uno de los tipos moleculares más relevantes debido a la capacidad de las células tumorales para desarrollar resistencia a los medicamentos, destacando la necesidad urgente de desarrollar nuevas y más seguras combinaciones de fármacos para su tratamiento. En este contexto, para superar la resistencia de células tumorales a los fármacos, se empleó un nuevo tratamiento combinatorio que incluye doxorrubicina (Dox), metformina (Met) y oxamato de sodio (Ox); (DoxMetOx). Tal combinación farmacológica tiene como objetivo ser el blanco de marcadores indispensables de cáncer relacionados con la glucólisis aeróbia y la síntesis de ácidos nucléicos (DNA y RNA).

Materiales y Métodos: Con el objetivo de elucidar el mecanismo de muerte celular promovido por los fármacos, se evaluó a nivel molecular la efectividad de los tratamientos sobre cultivos primarios de un modelo murino de xenotransplantes de CaMa TN de la línea celular MDA-MB-231. Los cultivos fueron expuestos a 4 tiempos de exposición a DoxMetOx y se realizaron análisis de Western Blot, Microscopia Electrónica de Transmisión (TEM) y microscopía de fluorescencia con la proteína verde fluorescente (GFP-LC3).

Resultados: La posible inducción de autofagia a través de la activación de la proteína LC3-II e inhibición de p-mTOR fue evaluada en los cultivos celulares expuestos a tratamientos farmacológicos individuales, dobles y con la triple terapia,. La Doxorrubicina aumentó notablemente la señal de p-mTOR desde las primeras cuatro horas de exposición en comparación a la Metformina y el Oxamato; y la acumulación de LC3-II no fue considerable para ninguna de las tres drogas. La combinación de Met/Ox después de 12 horas de tratamiento, tuvo un efecto inhibitorio de p-mTOR y un incremento moderado en la conversión de LC3-I a LC3-II desde las primeras 4 horas. Por otra parte, la terapia DoxMetOx a partir de las 4 horas de tratamiento inhibió por completo p-mTOR y aumentó significativamente la conversión de LC3-I a LC3-II al mismo tiempo de exposición del tratamiento. De igual modo en los ensayos de TEM y de GFP-LC3, la triple terapia indujo formación de 
autofagolisomas, sin embargo, con Doxorrubicina se observó daño masivo en tiempo corto. Estos resultados sugieren que la triple terapia probablemente induce autofagia temprana en el tumor, siendo aún más eficiente que la Doxorrubicina, fármaco de primera línea en CaMa TN.

Conclusiones: Los estudios in vitro mostraron que DoxMetOx actúan juntos inhibiendo la fosforilación de mTOR y la expresión del gen LDH-A, promoviendo la apoptosis dependiente de la vía de las caspasas, acompañada de escisión de PARP. Se observó que la inducción del proceso de autofagia fue promovido por la acumulación de LC3-II, una proteína primordial implicada en la conformación y elongación del autofagolisosoma y la culminación de la autofagia. Es por ello que dentro de éste contexto, la falta de fármacos eficaces para inhibir el crecimiento de CaMa TN, es la principal causa de la falta de éxito terapéutico y de la recurrencia de la enfermedad. En éste trabajo hemos demostrado que la orientación de la combinación de DoxMetOx hacia vías moleculares clave en el cáncer, resultó ser un eficiente y rápido inhibidor de la proliferación celular. Nuestros hallazgos muestran que esta combinación puede llegar a ser una estrategia prometedora para las pacientes diagnosticados con tumores $\mathrm{TN}$, para quienes desafortunadamente no existen terapias farmacológicas fiables.

Palabras clave: cáncer de mama triple negativo (CaMaTN), metformina, oxamato, doxorrubicina, mTOR, glucólisis aeróbia, autofagia y apoptosis. 


\section{ABSTRACT}

Background: Chemotherapy is the backbone of systemic treatment for triple negative breast cancer (TNBC), which is one of the most relevant breast cancers molecular types due to the ability of tumor cells to develop drug resistance, highlighting the urgent need to develop newer and safer drug combinations for treatment. In this context, to overcome tumor cell drug resistance, we employed a novel combinatorial treatment including Doxorubicin, Metformin, and Sodium Oxamate (DoxMetOx). Such pharmacological combination targets indispensable hallmarks of cancer-related to aerobic glycolysis and DNA synthesis.

Materials and Methods: The aim this work is analize the molecular level in BCTN cells line. Inhibition mTOR protein as well as the enzyme LDHA, and furthermore, induction of autophagy process generated by activating LC3, a primordial protein implicated in the conformation and elongation of the autophagolysosome. The induction autophagy was also determined by Transmision Electronic Microscopy (TEM) and Green Flourescent Protein GFP-LC3; both of them assys showing a considerable detection of LC3. Were also performed LDH-A activity assays, detection of apoptosis was determined through the release of LDH-A and glucose uptake. All treatments were compared with doxorubicin. Our results bring relevant implications for breast cancer treatment, they provide evidence about the link of apoptosis and autophagy employing mTOR and glycolysis inhibitors.

Results: Cell cultures exposed in pairs and with triple therapy were evaluated as potential inducers of autophagy through activation of the LC3-II protein and inhibition of p-mTOR. Doxorubicin markedly increased the p-mTOR sign from the first 4 hours of exposure compared to Metformin and Oxamate; and the accumulation of LC3-II was not significant for any of the three drugs. The combination of MetOx after 12 hours of treatment had a p-mTOR inhibitory effect and a moderate increase in the conversion of LC3-I to LC3-II from the first 4 hours. On the other hand, DoxMetOx therapy from 4 hours of treatment completely inhibited p-mTOR and significantly increased the 
conversion of LC3-I to LC3-II at the same time of treatment exposure. Similarly in the TEM and GFP-LC3 assays, triple therapy induced autophagosome formation after 4 hours of exposure, however massive damage was observed with Doxorubicin at this time. As for the LDH-A release and activity and glucose uptake assays, the cultures exposed to triple therapy showed the decrease in the enzyme a difference of Doxorubicin, where no significant changes in the decrease of this important molecular marker in some types of cancer. Regarding the uptake of glucose, we observed a favorable effect in the decrease of the same on the cultures exposed to the triple therapy a difference of Doxorubicin, where there was no significant effect. These results suggest that triple therapy induces early autophagy in the tumor, being even more efficient than Doxorubicin, a first line drug in CaMa TN.

Conclusions: in vitro studies showed that the three drugs act together inhibiting both mTOR phosphorylation and LDH-A gene expression, promoting caspase-3 dependent pathway apoptosis, accompanied by PARP cleavage. In addition, the induction of the autophagy process was observed by the accumulation of LC3-II, a primordial protein involved in the conformation and elongation of the autophagolysosome. The lack of effective drugs to inhibit the growth of CaMa TN, is the main cause of the lack of successful therapeutic failure and recurrence of the disease. In this work we have shown that the orientation of the combination of Doxorubicin, Metformin and Oxamate to key molecular pathways in cancer proved to be an efficient and rapid inhibitor of cell proliferation. Our findings prove to be a promising strategy for patients diagnosed with TN tumors, for whom unfortunately there are no reliable pharmacological therapies.

Keywords: Triple Negative Breast Cancer (TNBC), metformin, oxamate, doxorubicin, mTOR, aerobic glycolysis, autophagy and apoptosis. 


\section{INDICE}

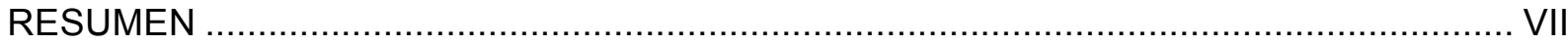

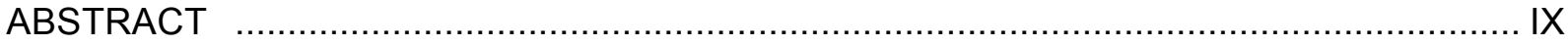

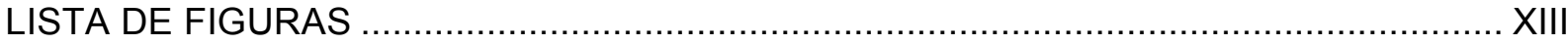

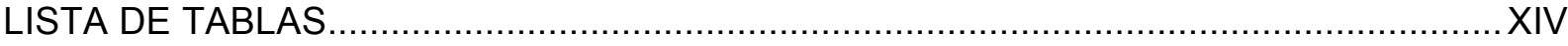

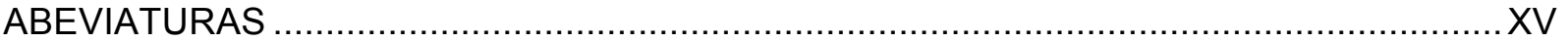

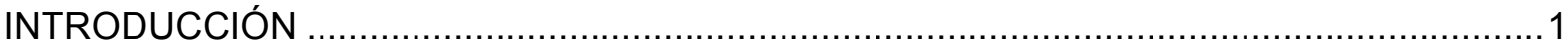

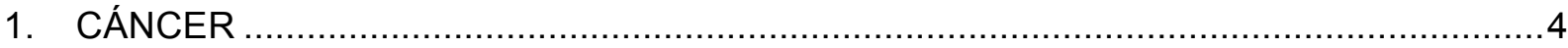

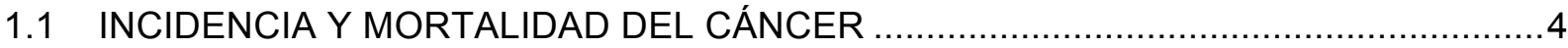

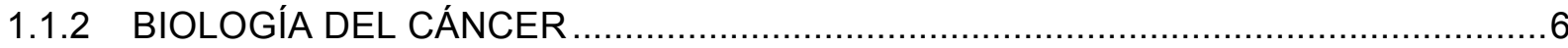

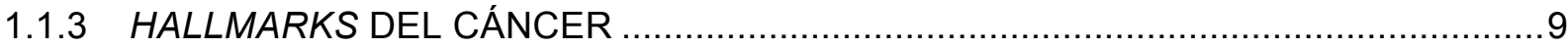

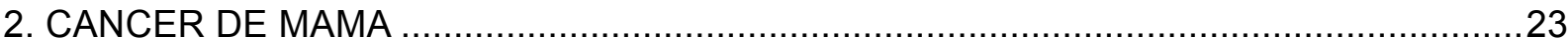

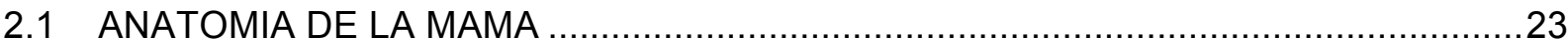

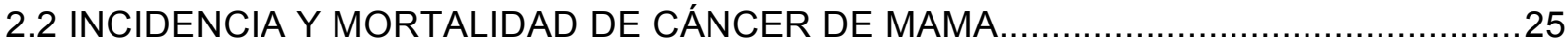

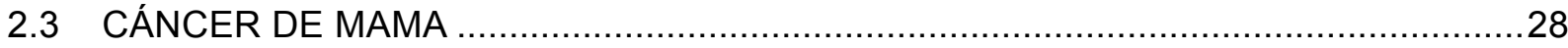

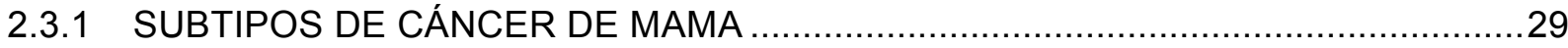

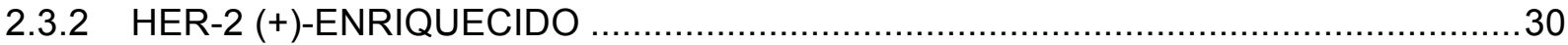

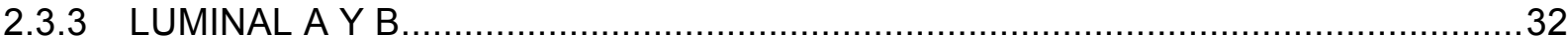

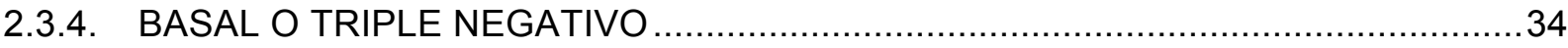

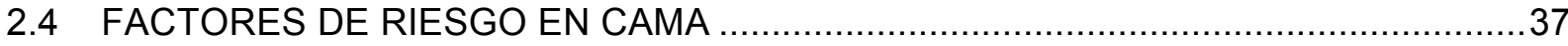

2.5 MÉTODOS DE PREVENCIÓN Y DIAGNÓSTICO DE CAMA ……............................39

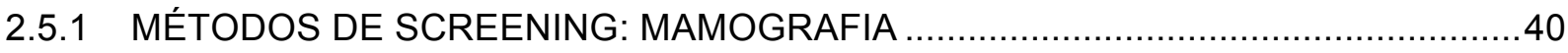

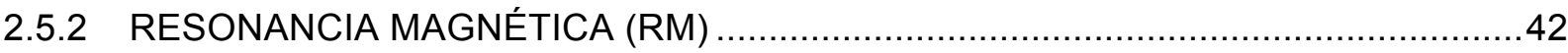

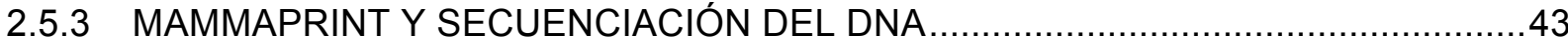

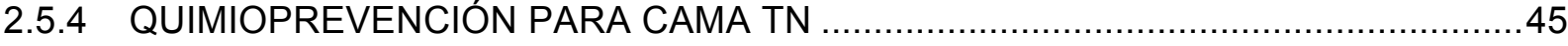

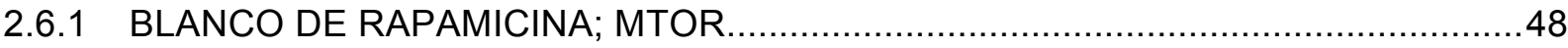

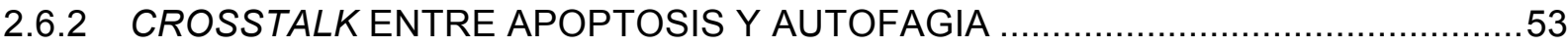

3. METABOLISMO DE LA CÉLULA TUMORAL: EFECTO WARBURG..............................61

3.1 TERAPIAS FARMACOLÓGICAS INHIBIDIDORAS DEL METABOLISMO …...............67

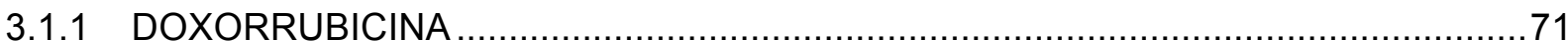

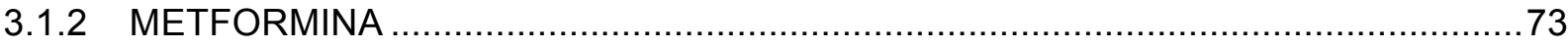

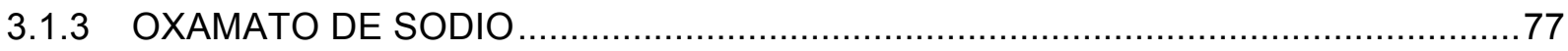

3.1.4 COMBINACIÓN: DOXORRUBICINA-METFORMINA-OXAMATO DE SODIO ............81 


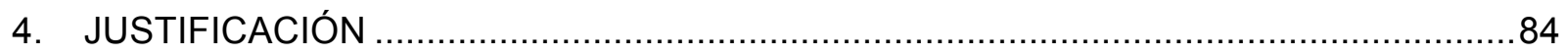

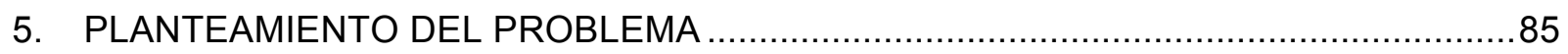

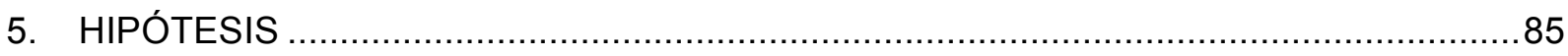

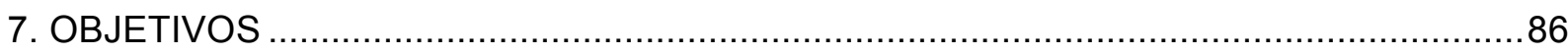

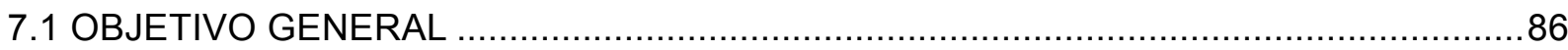

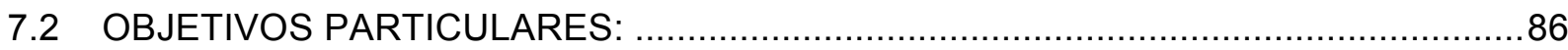

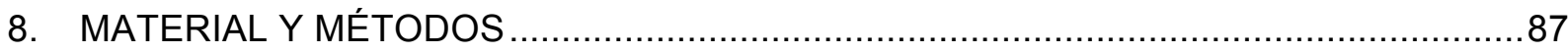

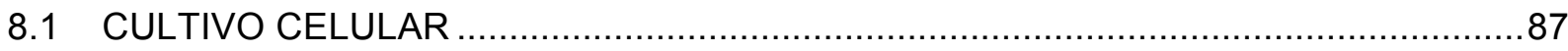

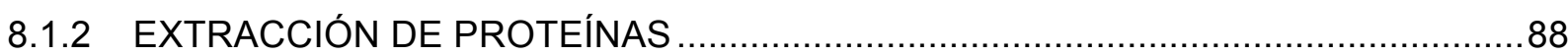

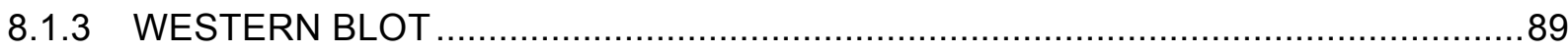

8.1.4 CONSTRUCCIÓN DEL PLÁSMIDO PARA EXPRESIÓN DE PROTEÍNA VERDE

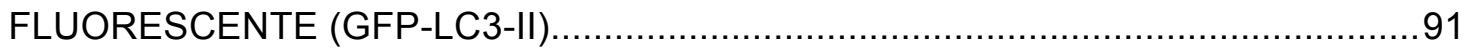

8.1.5 TRANSFECCIÓN POR LIPOFECTAMINA PARA EXPRESIÓN DE PROTEÍNA

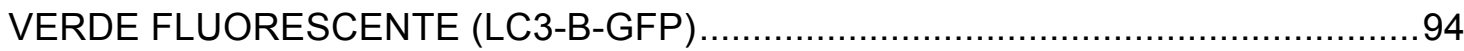

8.1.6 ANÁLISIS DE ULTRAESTRUCTURA MEDIANTE MICROSCOPÍA DE

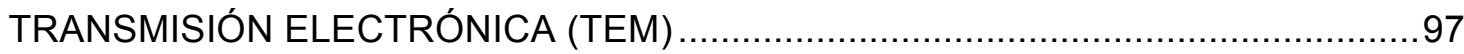

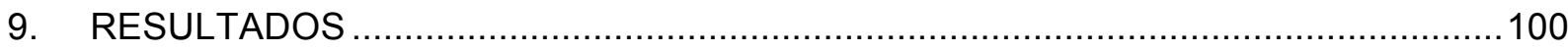

9.1 EFECTO DE LOS FÁRMACOS INDIVIDUALES Y LA TRIPLE TERAPIA EN LA ACTIVACIÓN DE LA APOPTOSIS EN LA LÍNEA CELULAR MDA-MB-231 ..............100

9.1.2 EFECTO DE DOXMETOX EN LA PROBABLE INDUCCIÓN DE AUTOFAGIA A TRAVÉS DE LA ACTIVACIÓN DE LA PROTEÍNA LC3 Y LA INHIBICIÓN DE LA FOSFORILACIÓN DE MTOR.

9.1.3 DOXMETOX PROMUEVE LA INHIBICIÓN DE LA EXPRESIÓN DE LA LDH-A A

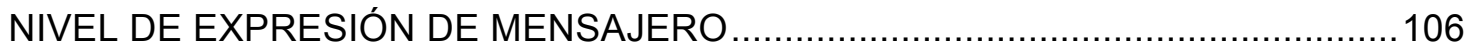

9.1.4 DOX NO PROMUEVE MUERTE CELULAR PROGRAMADA Y SU EFECTO CITOTÓXICO INDUCE DAÑO CELULAR MASIVO 108

9.1.5 EL EMPLEO DE DOXMETOX PROMUEVE FORMACIÓN DE AUTOFAGOLISOSOMAS POR ACTIVACIÓN DE AUTOFAGIA

9.1.6 DETECCIÓN DE AUTOFAGIA MEDIANTE LA LOCALIZACIÓN INTRACELULAR DE AUTOFAGOSOMAS A TRAVÉS DE GFP-LC3 INDUCIDA POR DOXMETOX........113

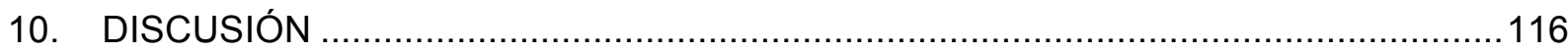

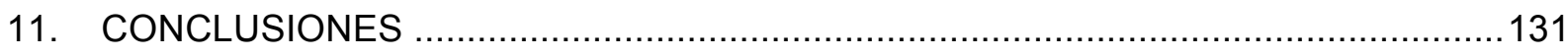

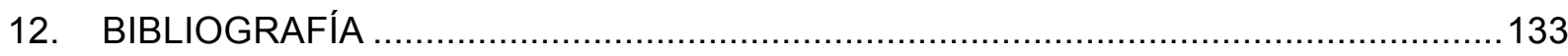

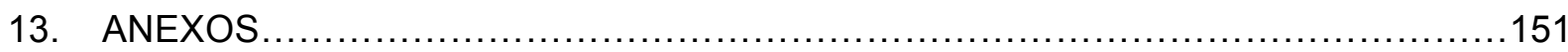




\section{LISTA DE FIGURAS}

Figura 1. Incidencia y mortalidad de cáncer en ambos sexos a nivel mundial......5

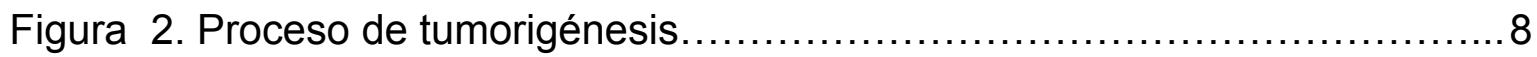

Figura 3. Caracteristicas distintivas o "hallmarks del cáncer".

\section{Error! Bookmark not defined.}

Figura 4. Procesos de establecimiento de la tumorigénesis..................... 14

Figura 5. Proceso de muerte celular por Apoptosis............................. 16

Figura 6 . Proceso de regulación de Autofagia .....................................22

Figura 7 . Estructura básica de la mama....................................... 24

Figura 8. Mortalidad por cáncer cérvico-uterino y mama en nuestro país........... 26

Figura 9. Establecimiento de células tumorales en la glándula mamaria......... 29

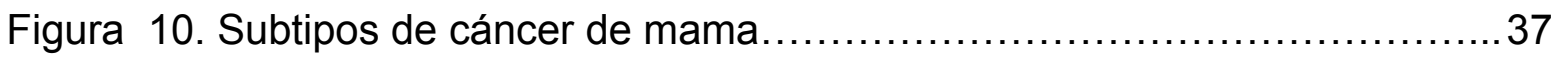

Figura .11. Factores de riesgo y prevención en cáncer de mama................. 47

Figura 12. vía mTOR en el metabolismo de la célula tumoral........................52

Figura 13. Interacción entre apoptosis y autofagia................................6

Figura 14. Glucólisis aerobia o efecto Warburg.................................6 63

Figura 15. Microtomografia Emisora de Posotrones microPET ..................... 83

Figura 16. Ensayos de construcción de plásmido para GFP-LC3 ..................92

Figura 17. Ensayos de obtención de proteína de fusión.............................93

Figura 18. Detección de marcadores de Apotosis mediante WB....................102

Figura 19. Detección de marcadores de autofagia mediante WB....................105

Figura 20. Inhibición de la LDH-A por la triple terapia............................ 107

Figura 21. Análisis de ultraestructura en líneas de CaMa TN con Dox.............. 110 
Figura 22. Análisis de ultraestructura en líneas de CaMa TN con DoxMetOx....112

Figura 23. Expresión de GFP-LC3 en 3 líneas celulares de CaMa TN.............115

Figura 24. Posible mecanismo de acción de DoxMetOx..........................132

\section{LISTA DE TABLAS}

Tabla 1. Proteínas con doble papel en Apoptosis y Autofagia.................................54

Tabla 2. Fármacos anticancerígenos con blanco terapéutico en el efecto Warburg. 70

Tabla 3. Relación de anticuerpos primarios y secundarios en la detección de

Apoptosis y Autofagia y glucólisis en cultivos primaries de CaMa. ...........................90

Tabla 4. Componentes empleados en la transfección transitoria de pEGFPN1-LC3 en

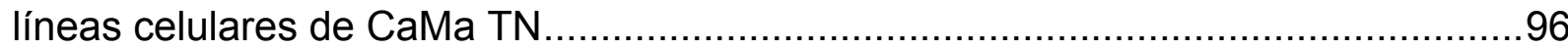




\section{ABEVIATURA}

${ }^{18}$ FDG: ${ }^{18}$ Fluoro-desoxiglucosa-18, radioactivo)

ADNmt: Ácido Desoxirribonucléico mitocondrial

Al: inhibidores de la aromatasa

Akt: Proteina cinasa-B

AMPK: Adenosin Monofosfato cinasa

ADN: Ácido Desoxirribonucleico

ARN: Ácido Ribonucléico

ATCC: American Type Culture

Collection

Atg: genes relacionados con autofagia

ATP: Adenosin Trifosfato

BRCA1: Breast Cancer Type I

BRCA2: Breast Cancer Type 2

CaMa TN: Cáncer de Mama Triple

Negativo

BCTN: Breast Cancer Triple Negative

CaMa: Cáncer de Mama

CE: células endoteliales

cit-c: citocromo c

DD: Dominio de muerte

DMT2: Diabetes Mellitus Tipo 2

Dox: Doxorrubicina

DoxMetOx: Doxorrubicina-Metformina-

Oxamato

EGF: Factor de Crecimiento

Epidérmico
EGFR: Receptor del Factor de

Crecimiento Epidérmico

FADD: proteína asociada a Fas con dominio de muerte

GADPH: Gliceraldehido 3-fosfato

deshidrogenasa

GFP-LC3: Proteína Verde

Fluorescente-LC3

GLUTs: Transportadores de Glucosa

GTP: Guanosina 5-Trifosfato

HER-2: Receptor 2 del Factor de Crecimiento Epidérmico Humano HIF-1 $\alpha$ : Factor Inductor de Hipoxia-1 alfa

LC3: Proteína de Cadena Ligera-3 asociada a microtúbulos

LDH-A: Lactato Deshidrogenasa tipo A MEC: Matriz Extracelular

Met: Metformina

microPET: micro-Tomografía Emisora de Positrones mTOR: Blanco de Rapamicina en mamíferos

mTORC1: Proteína Reguladora-1

asociada a mTOR

mTORC2: Proteína Reguladora-2

asociada a mTOR 
$\mathrm{NAD}^{+}$: Nicotinamida Adenina

Dinucleótido

NADH: Nicotinamida Adenina

Dinucleótido Hidrogenado

Ox: Oxamato

p-mTOR: Blanco de Rapamicina en mamíferos fosforilado

PARP: Poli-ADP-Ribosa Polimerasa

PBS: Buffer Salino Fosfatos

PD1: proteína de muerte celular programada-1

PET: Tomografía Emisora de

Positrones

PI: Fosfatidil Inositol

PI3K: Fosfatidil inositol 3-cinasa

$\mathbf{R b}$ : proteína de Retinobalstoma

RD: receptores de muerte

RE: Receptor de Estrógeno

RM: Resonancia Magnética

ROS: Especies Reactivas de Oxigeno
RP: Receptor de Progesterona

RR: Riego Relativo

SERM: Moduladores Selectivos de los

Receptores Estrogénicos

SFB: Suero Fetal Bovino

TAM: tamoxifeno

TEM: Microscopia de Transmisión

Electrónica

TN: Triple Negativo

TNF-R: Receptor del Factor De

Necrosis Tumoral

TNF: Factor De Necrosis Tumoral

TRADD: proteína de Dominio de

muerte TNF-R tipo 1

ULK-1: Cinasa activadora de la autofagía Unc-51

VEGF: factor de Crecimiento Endoteial

Vascular

Vps34: proteína vesicular 34 


\section{INTRODUCCIÓN}

El cáncer de mama (CaMa) es un problema de salud mundial, es considerado como una de las principales causas de muertes relacionadas con el cáncer en las mujeres (Jemal et al., 2011). Tan sólo en el 2012, cerca de 1,7 millones de nuevos casos de CaMa se registraron en todo el mundo, lo que representó cerca del $12 \%$ de todos los cánceres en ese año (Ferlay et al., 2015). Se prevé que para el 2030, se genere un estimado de 23764 nuevos casos y 6591 muertes por CaMa (Chávarri-Guerra et al., 2012). Se estima que alrededor de la mitad de los casos de CaMa y más del $50 \%$ de las muertes, ocurren en países económicamente en vías de desarrollo. En México desde el 2006 la mortalidad por CaMa, ha ido en aumento, desplazando en el 2005 al cáncer cervicouterino ( $\mathrm{CaCu})$; pasando de ocupar el segundo lugar en incidencia y mortalidad a ocupar el primer lugar respectivamente (Chávarri-Guerra et al., 2012). Con base en diversas pruebas moleculares se ha logrado caracterizar al CaMa en tres principales grupos, basados en su perfil molecular: Luminal A, Luminal B y Basal-like; el CaMa Luminal A se caracteriza por ser positivo para los Receptores de Estrógeno (RE) y Receptores de Progesterona (RP) (Creighton, 2012). Su terapia se basa en moduladores específicos de RE, dentro de la cual sobresale el Tamoxifen. El CaMa luminal B representa a los tumores negativos para RE y RP pero positivos para el Factor de Crecimiento Epidermal-2 (HER-2). Su terapia se basa en el empleo de Traztuzumab, el cual es un anticuerpo monoclonal que se une a HER-2 e inhibe la proliferación de la células (Duffy, McGowan, \& Crown, 2012). Finalmente el Basal-like o clínicamente referido como Triple Negativo (TN); agrupa tumores de mama con 
ausencia de RE, RP y HER-2; representa el fenotipo de peor pronóstico en términos de sobrevivencia y periodo libre de enfermedad a diferencia de los otros fenotipos tumorales, actualmente para el fenotipo TN no existe una terapia exitosa (Mc Carthy et al; 2012). La mayoría de los tumores TN presentan una historia clínica agresiva con un alto grado patológico y metastásico (Chen et al; 2012). Los tumores TN suelen ser de grado 3, con un alto índice mitótico, infiltrado celular y centro necrótico (de Ruijter et al; 2011). Los pacientes que lo presentan tienen un alto riesgo de recurrencia temprana que va de entre 1-3 años después de la cirugía y culmina con una mayor tasa de mortalidad a los 5 años después de la quimio y radioterapia (Young et al; 2009). En todo el mundo, aproximadamente el 15\% de los tumores de mama corresponden al fenotipo TN (Dent et al., 2007). Desafortunadamente, en la actualidad no existe un tratamiento específico para estos pacientes; sin embargo, el tratamiento estándar consiste en cirugía, radiación y tratamientos coadyuvantes basados en antraciclinas y taxanos, tales como: doxorubicina, gemcitabina, capecitabina, entre otros. Las principales consecuencias de los agentes quimioterapéuticos actuales son la cardiotoxicidad y la neurotoxicidad en los pacientes con prolongados periodos de tratamiento (Cárdenas Sánchez et al., 2010). Anteriormente la mayoría de los tipos de cáncer, entre ellos el CaMa, eran considerados sólo como una enfermedad genética, de hecho, la mayoría de los tratamientos eran basados en la inhibición de la reparación de daño a DNA. No obstante, recientemente este concepto ha cambiado y actualmente se aborda al cáncer como una enfermedad metabólica (Soga, 2013). Una de las aportaciones más importantes al respecto es el denominado "efecto Warburg" o glucólisis aerobia. Este 
fenómeno descubierto por Otto Warburg en 1923 establece que las células tumorales presentan un incremento en su tasa glucolítica con respecto a las células normales, tal atributo le permite a la célula tumoral proliferar velozmente y mantener una fuente constante de energía, mostrándolo como un blanco terapéutico prometedor (Gwinn et al; 2008). Dentro de éste contexto, en este proyecto de tesis se propuso la evaluación a nivel molecular de los efectos de la triple terapia farmacológica: DoxMetOx como inhibidores clave de las vías de generación de energía de la célula tumoral, para evaluar su probable participación en la inducción de autofagia y/o apoptosis en un modelo in vitro de CaMa TN. Los resultados presentados, demuestran que esta combinación farmacológica inhibe la proliferación de la célula tumoral de CaMa TN, a través de la modificación de tres mecanismos de suma importancia en la célula tumoral: inducción de muerte por apoptosis y autofagia dependiente de caspasas y mediante la promoción de LC3-II y la inactivación de pmTOR, respectivamente y el bloqueo de la glucólisis aerobia mediante la inhibición de la LDH-A. 


\section{Cancer}

\subsection{Incidencia y Mortalidad del Cáncer}

Actualmente se sabe que sólo del $5-10 \%$ de los tumores se puede atribuir a defectos genéticos, mientras que del $90-95 \%$ restante tiene sus raíces en el medio ambiente y estilo de vida, de todas la muertes relacionads con el cáncer, aproximadamente del $25-30 \%$ se deben al tabaco, el $30-35 \%$ están relacionadas con la dieta, mientras que del $15-20 \%$ se deben a algún tipo de infección y el porcentaje restante se debe a otros factores como la radiación, el estrés, la inactividad física, contaminantes ambientales, entre otros (Anand et al., 2008). A nivel mundial, 1 de cada 8 muertes se debe a ésta enfermedad, de acuerdo a reportes del año 2010 la Organización Mundial de la Salud (OMS), la muerte por cáncer ha sustituido a la muerte por isquémia del corazón como la principal causa de muerte en todo el mundo (Freedman \& Partridge, 2011). Los tipos de cáncer más diagnosticados a nivel mundial son el pulmonar, mama y colorrectal (Figura 1) (Ferlay et al., 2010). CaMa y pulmonar, son las neoplasias de mayor incidencia (23\%), así como las principales causas de muerte en mujeres (17\%) y hombres (14\%), respectivamente. Con base en estimaciones del GLOBOCAN en el 2008, en países de mediano y bajo ingreso a nivel mundial, el 53\% (12.7 millones) corresponde a nuevos casos y el $47 \%$ (7.6 millones) a defunciones por cáncer. La carga global por ésta enfermedad sigue aumentando en gran parte debido al envejecimiento y crecimiento de la población, aunado al creciente aumento en el consumo de tabaco en países en vías de desarrollo (Jemal et al., 2011). 


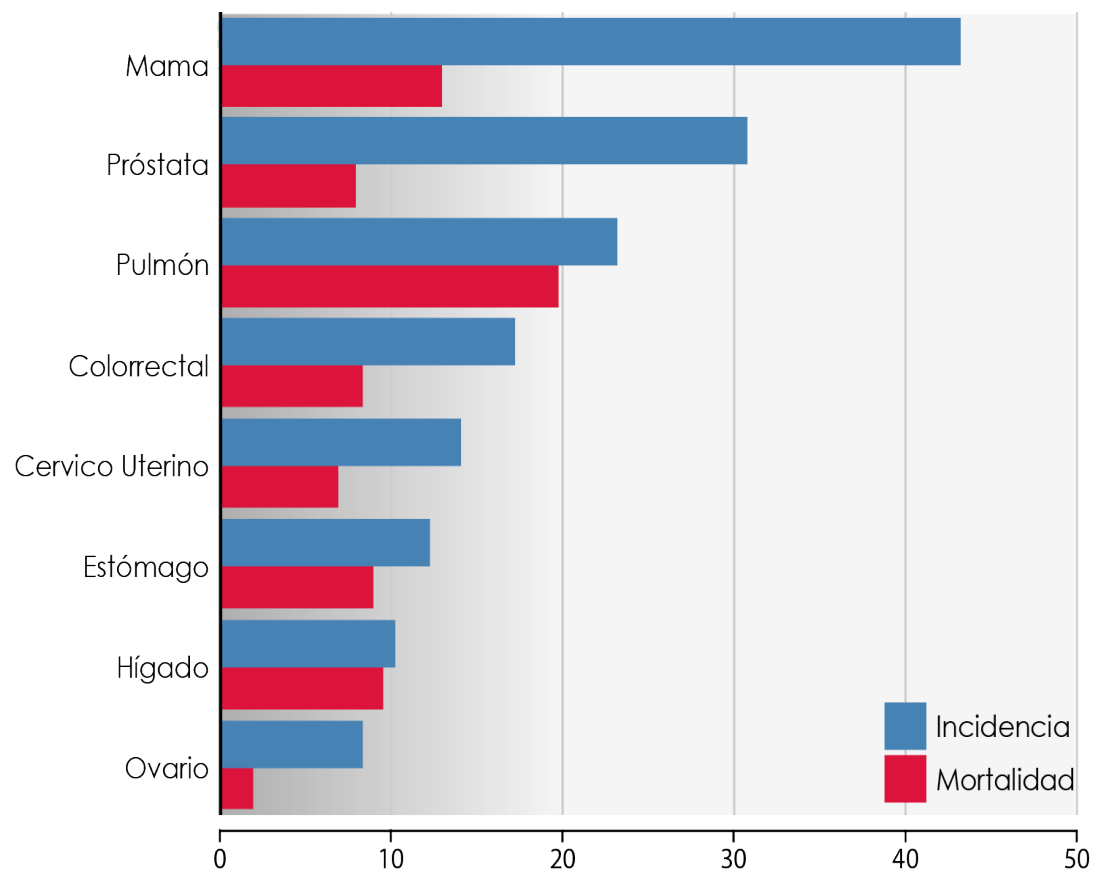

Figura 1. Incidencia y mortalidad de los diferentes tipos de cáncer en ambos sexos a nivel mundial (Tasa por cada 100,000 personas) (Tomada y modificada de Ferlay et al, 2015).

Una proporción considerable de la incidencia mundial del cáncer, podría prevenirse mediante la implementación de tratamientos y programas de detección temprana, así como de control del tabaco, la vacunación (para el cáncer cervico uterino) y campañas de salud pública que promuevan la actividad física y la ingesta de una dieta saludable (Release, 2013). 


\subsubsection{Biología del Cáncer}

El cáncer se ha caracterizado como un proceso complejo de múltiples enfermedades que pueden afectar cualquier órgano del cuerpo; involucra diversos cambios dinámicos en el genoma y se establece cuando las células son incapaces de formar estructuras funcionales estables; lo que promueve una división descontrolada (Floor, Dumont, Maenhaut, \& Raspe, 2012). La evolución progresiva de modificaciones bioquímicas y biológicas a las que se enfrenta la transformación de la célula normal a un estado neoplásico, radica en la adquisición sin limite de capacidades autónomas de replicación, proliferación, invasión y sobrevivencia, por sólo mencionar algunas (González Angulo et al; 2011 y (Paulmurugan, 2012). La dinámica de estas modificaciones incipientes en las células junto con su microambiente, orquestan de manera conjunta la adquisición de los rasgos necesarios para el establecimiento de la tumorigénesis y a la vez generar eventos cruciales para su mantenimiento y sobrevivencia (Lorusso \& Rüegg, 2008). De manera particular, si la célula pierde la capacidad de responder a factores inhibidores del crecimiento y la proliferación, se genera como consecuencia la acumulación progresiva de defectos en el genoma que contribuyen en conjunto a la progresión tumoral.

En el 2002 Hanahan y Weinberg establecieron una serie de características biológicas; mejor conocidas como "hallmarks del cancer" que son necesarias para el establecimiento de la enfermedad (Hanahan \& Weinberg, 2002). Los hallmarks son una herramienta útil para organizar el conocimiento de la biología de la enfermedad, 
que de manera conjunta participan en la generación del microambiente celular que promueve exitosamente su establecimiento. Los hallmarks, programas y eventos oncogénicos de las células, se deben considerar como componentes de una red dinámica que se encuentran interrelacionados y en constante evolución, que pueden diferir de una célula a otra y en diferentes momentos dentro de la misma; es decir, una estructura que opera en una heterogeneidad dinámica espacio-temporal (Plate, Scholz, \& Dumont, 2012).

Actualmente se sabe que el desarrollo y la progresión del cáncer, desde etapas neoplásicas hasta el tumor con capacidad de invasión y metástasis, comprenden una cadena de eventos complejos y sucesivos (Mullan y Millikan, 2007); estos eventos consisten en diversos episodios de expansión clonal de células somáticas, durante los cuales el genoma de la célula pre-cancerosa adquiere la capacidad autónoma de proliferación y sobrevivencia sin límites, mediante la activación de oncogenes e inactivación de genes supresores, que controlan de forma directa o indirecta la proliferación y muerte celular; ésta propagación no controlada de las células puede estar generada a partir de factores causales externos como el tabaco, productos químicos, radiación, organismos infecciosos, entre otros e internos como las mutaciones heredadadas, perfiles hormonales, aberraciones inmunológicas $y$, recientemente retomado, las mutaciones producidas a partir del metabolismo energético, mediante la participación del Factor Inductor de Hipóxia-1 alfa (HIF-1a por sus siglas en inglés), c-Myc y la Lactato Deshidrogenasa-A (LDH-A), que pueden combinarse o actuar de manera conjunta para iniciar y promover la enfermedad. Así, 
el establecimiento del fenotipo tumoral en el organismo, puede describirse como el resultado de alteraciones biológicas promovidas por éstos factores, que ocurren en células normales en un proceso de pasos múltiples que involucra cambios a nivel genético, seguido por la promoción y la progresión de un fenotipo tumoral, que finalmente puede llegar a producir tumores benignos o malignos; Figura 2 (Link et al; 2010).

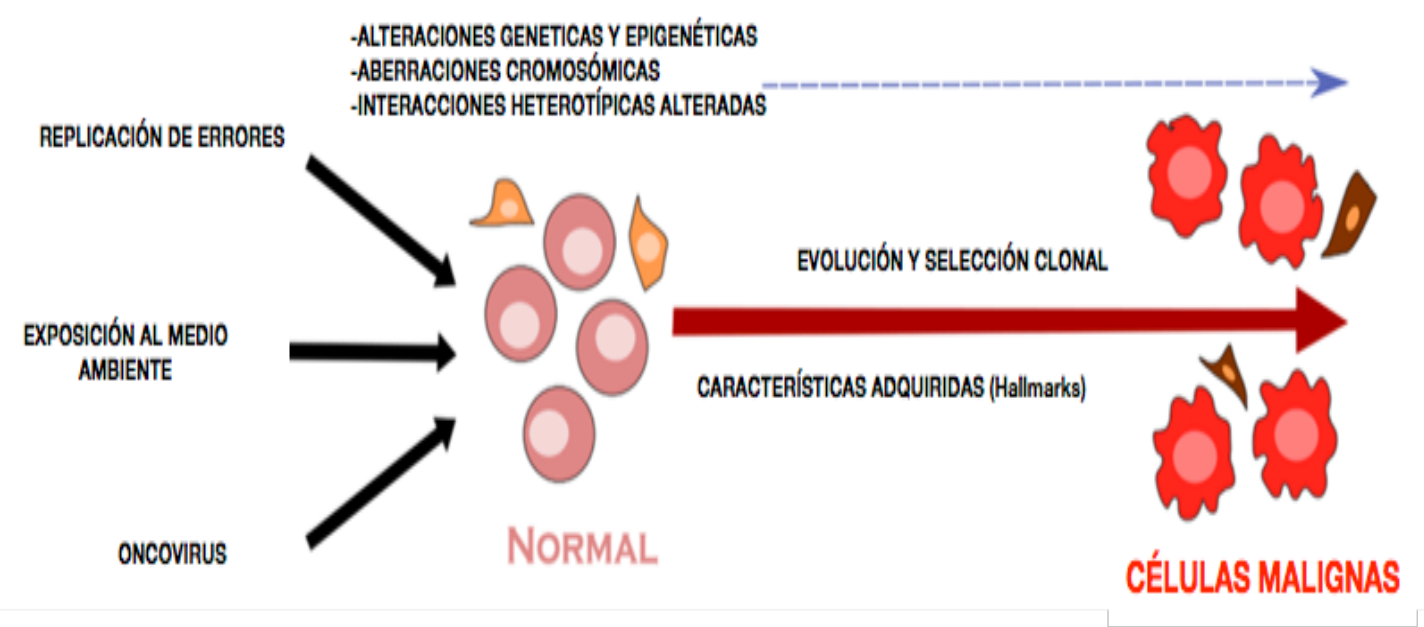

Figura 2. Proceso de tumorigénesis. Distintos factores actúan continuamente sobre las células, los cuales promueven la malignidad de la célula tumoral. Estos factores comprenden: alteraciones genéticas y epigenéticas, aberraciones cromosómicas e interacciones heterotípicas alteradas, que se van adquiriendo a lo largo del camino hacia la malignidad. Las células se someten a ciclos de selección clonal evolutiva que conducen a la adquisición de los Hallmarks para la promoción del cáncer (Tomada y modificada de Link et al ; 2010.

Yousef Ahmed Fouad y Carmen Aanei en el 2017, establecieron que los hallmarks no necesariamente están presentes de manera continua; es por ello que la gran mayoría de los tipos celulares presentan una enorme variedad de funciones génicas alteradas, incluyendo la activación de genes promotores del crecimiento y el silenciamiento de genes con funciones supresoras del mismo; éstas alteraciones, 
colaboran en la evasión de mecanismos de control de crecimiento, lo que conlleva a la proliferación descontrolada.

\subsubsection{Hallmarks del cáncer}

El proceso de tumorigénesis está mediada por la manifestación de alteraciones o características distintivas del cáncer, que son esenciales en la fisiología de la célula y que dictan su crecimiento maligno. Cada uno de estos cambios fisiológicos involucra nuevas capacidades adquiridas durante el desarrollo de la célula cancerosa, lo que representa un escenario exitoso para el desarrollo del tumor, adquiriendo una sucesión de procesos que le permita ser maligno en última instancia (Tommasi et al; 2013) por Hanahan y Weinberg en el año 2000, quienes las agruparon en 8 funciones biológicas esenciales, que promueven de forma complementaria la transformación de células fenotípicamente normales en células malignas: 1) la proliferación sostenida, 2) evasión de los mecanismos supresores de crecimiento, 3) inducción de invasividad y metastásis, 4) inmortalidad replicativa, 5) angiogénesis, 6) sobrevivencia, 7) inestabilidad genómica y mutaciones e 8) inflamación. Sin embargo con base en los avances conceptuales en la última década, éstos mismos autores, en el 2011 añadieron dos "hallmarks" emergentes a la lista anterior: 9) la evasión en los procesos de destrucción del sistema inmune y 10) la reprogramación del metabolismo energético; todas éstas características, orquestan de manera conjunta para la promoción del desarrollo exitoso de la célula tumoral, aunado a lo anterior también le confiere a las células cierta dimensión de complejidad e inestabilidad en el 
genoma, generando una diversidad génica que facilita su sobrevivencia. Éstos "hallmarks" le proporcionan a la célula un "microambiente tumoral" altamente coordinado con capacidades moleculares y bioquímicas favorables que aumenta su capacidad de sobrevivencia (Figura 3) (Hanahan y Weinberg, 2011).

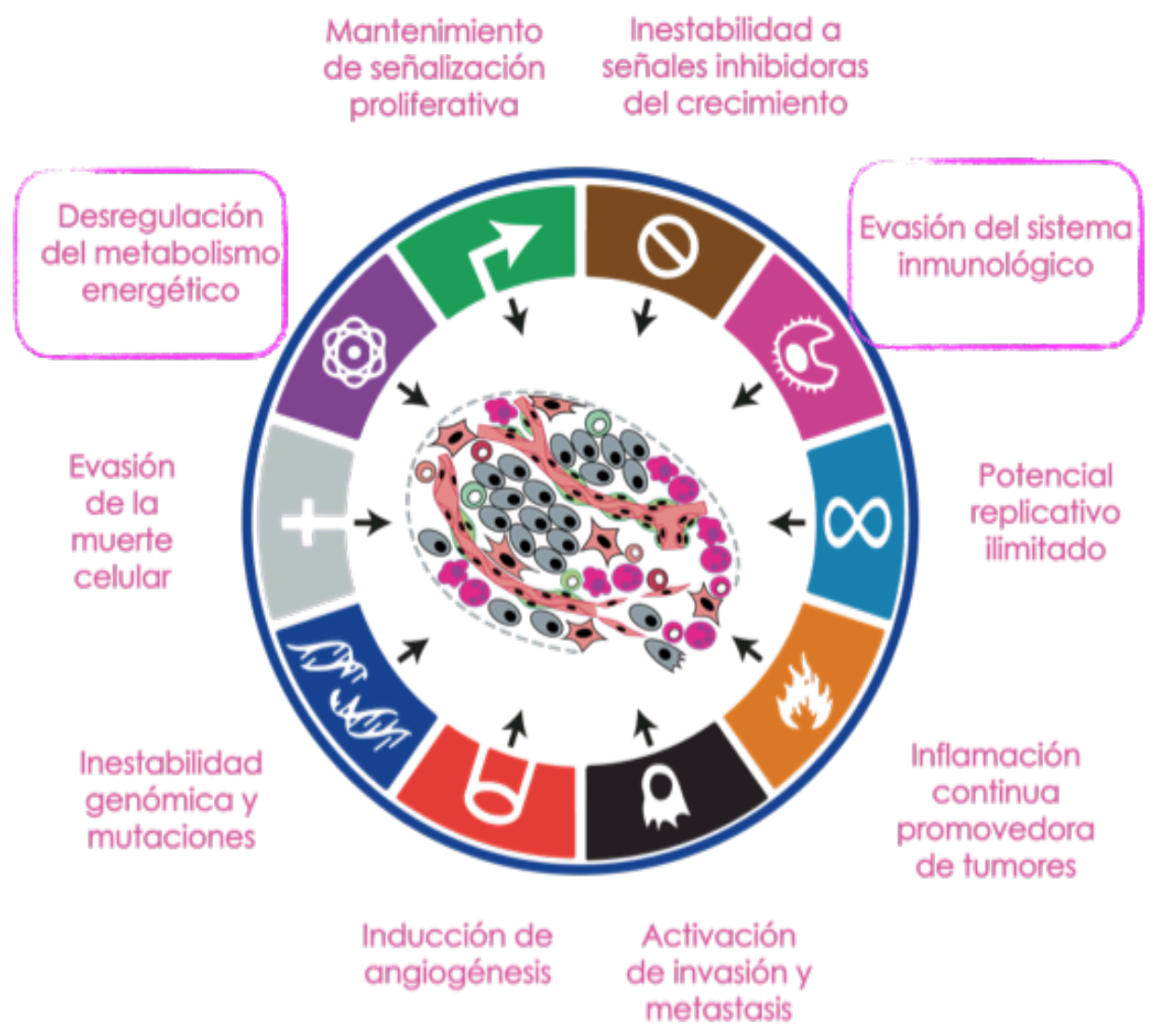

Figura 3. Caracteristicas distintivas o "hallmarks del cáncer" Estas capacidades incluyen diversos proceso que promueven el estableciemiento de la tumorigénesis para proporcionar a la célula tumoral un microambiente exitoso. Tomado y modificado de Hanahan y Weinberg, 2011). 
Para que las células cancerosas crezcan, la desregulación del ciclo celular y la interrupción de sus puntos de control son cruciales. Un regulador clave es la proteína del retinoblastoma (por sus siglas en inglés, Rb), comúnmente inactivada en una multitud de tumores malignos, como es el caso con RAS, se ha demostrado que la familia $\mathrm{Rb}$ no se limita al control proliferativo, sino que está involucrada en múltiples funciones (Dick \& Rubin, 2013), que afectan a otros hallmarks que incluyen el mantenimiento de la estabilidad genómica, la regulación de la apoptosis, el metabolismo celular, la senescencia, angiogénesis y la supresión de invasión y metástasis (Weinberg, 1995).

Otro regulador clave es p53, un gen implicado en cáncer con altas tasas de mutación en más del $50 \%$ de los tumores secuenciados. p53 actúa como un detector de estrés, siendo sensible a una variedad de irregularidades que incluyen: estrés genotóxico, señalización excesiva, privación de nutrientes e hipoxia, promoviendo la reprogramación metabólica, la regulación de la autofagia y la homeostasis (M. P. Kim, Zhang, \& Lozano, 2015). Para detener la proliferación, p53 participa en el inicio de los mecanismos de reparación, pero si el daño no se puede reparar, inicia la muerte celular o los estadios de diferenciación terminal (Hill, Song, Cardiff, \& Van Dyke, 2005). Un mecanismo que la célula emplea en presencia de estrés y factores externos es la reparación del DNA, en este mecanismo las vías de reparación trabajan de manera coordinada para modificar un tipo específico de lesión de DNA (Kelley, Logsdon, \& Fishel, 2014); es por ello que la acumulación de aberrantes eventos genéticos no reparados (mutaciones persistentes) junto con la composición 
genética inestable de la mayoría de los tumores promueven defectos en la maquinaria de reparación de la tumorigénesis (Bartkova et al., 2005).

Otro mecanismo de defensa contra el estrés celular es la senescencia, que implica el proceso de salida irreversible del ciclo celular; esto involucra el acortamiento crítico de los telómeros después del agotamiento del potencial de replicación. La inducción de la senescencia y las sucesivas divisiones celulares, conducen a ciclos de fusión y ruptura cromosómica, lo que da lugar a la inestabilidad genómica y asi finalmente permitir la acumulación potencial de alteraciones que transforman la estabilidad genómica (Campisi, 2013). También existe otro mecainsmo importante que se activa en el establecimiento de la tumorigénesis; la angiogénesis que en condiciones basales se desactiva o puede ser prolongada pero autolimitada (Welti, Loges, Dimmeler, \& Carmeliet, 2013), sin embargo en las células malignas el proceso se activa continuamente y su regulación esta determinada por la activación o inactivación de factores pro y anti-angiogénicos que se promueve cuando exista un factor que conlleve al desarrollo de una neoplasia maligna (Carmeliet \& Jain, 2011).

El factor que promueve este mecanismo es la hipoxia; dentro de este contexto las células endoteliales (CE's) poseen varios mecanismos que regulan la expresión de una multitud de genes (Yongzhi Yang, Sun, Wang, \& Jiao, 2013). En la hipoxia, HIF$1 \alpha$ estable inicia una respuesta transcripcional adaptativa, los productos de esta respuesta son factores involucrados que activan la angiogénsis; sus niveles son 
mucho más altos en la mayoría de los fenotipos tumorales lo que lo convierte en un marcador predictivo importante en cáncer. Los efectores de angiogenesis incluyen una amplia gama de moléculas pro-angiogénicas como lo es el Factor de Crecimeinto Endotelial Vascular (por sus siglas en inglés, VEGF), regulado por la actividad de HIF-1 $\alpha$. Diversos estudios han mostrado la sobreexpresión de VEGF en una multitud de tumores malignos y en forma activa conduce a la proliferación, supervivencia, migración y diferenciación de las CE's y a la mediación de la permeabilidad vascular (Sakurai \& Kudo, 2011). Existe una cantidad de efectores independientes de VEGF; que pueden trabajar de forma complementaria, independiente o compensatoria para su señalización (Ferrara, Gerber, \& LeCouter, 2003). La vasculatura de los tumores difiere de los normales, debido a que el flujo sanguíneo se genera en las áreas resultantes de hipoxia y acidosis; estas condiciones estresantes para la célula genera una serie de efectos que incluyen la potenciación de la angiogénesis, disminución de la eficacia terapéutica y resistencia a la expansión clonal resistente (Kieran, Kalluri, \& Cho, 2012).

Otras caracteristicas de la malignidad celular son la invasión y la metástasis; que implican la capacidad de invadir el tejido circundante y colonizar en sitios distantes para formar tumores secundarios; (Sceneay, Smyth, \& Möller, 2013). Para que las células cancerosas colonicen sitios distantes deben: 1) invadir y atarvesar la matriz extracelular (MEC), incluida la membrana basal y las células estromales, 2) intravasar la vasculatura tumoral, 3) sobrevivir al transporte en el torrente sanguíneo, 
4) extravasar en el parénquima de órganos distantes, 5) sobrevir y manipular microambientes (Massagué \& Obenauf, 2016). De manera importante, también se ha demostrado que los cánceres adquiridos exhiben defectos en las vías de reparación a medida que evolucionan, y los polimorfismos que implican genes de reparación se han correlacionado con el riesgo de cáncer; es probable que estos respondan con más éxito, debido a la variabilidad de la respuesta terapéutica, ya que la mayoría de las terapias contra el cáncer son diseñadas para inducir daño en el DNA (Goode, Ulrich, \& Potter, 2002). Por lo tanto, las vías de reparación del ADN se consideran reguladores multidimensionales en el contexto del cáncer, cuya alteración es favorable para la sobrevivencia y progresión tumoral (Figura 4).

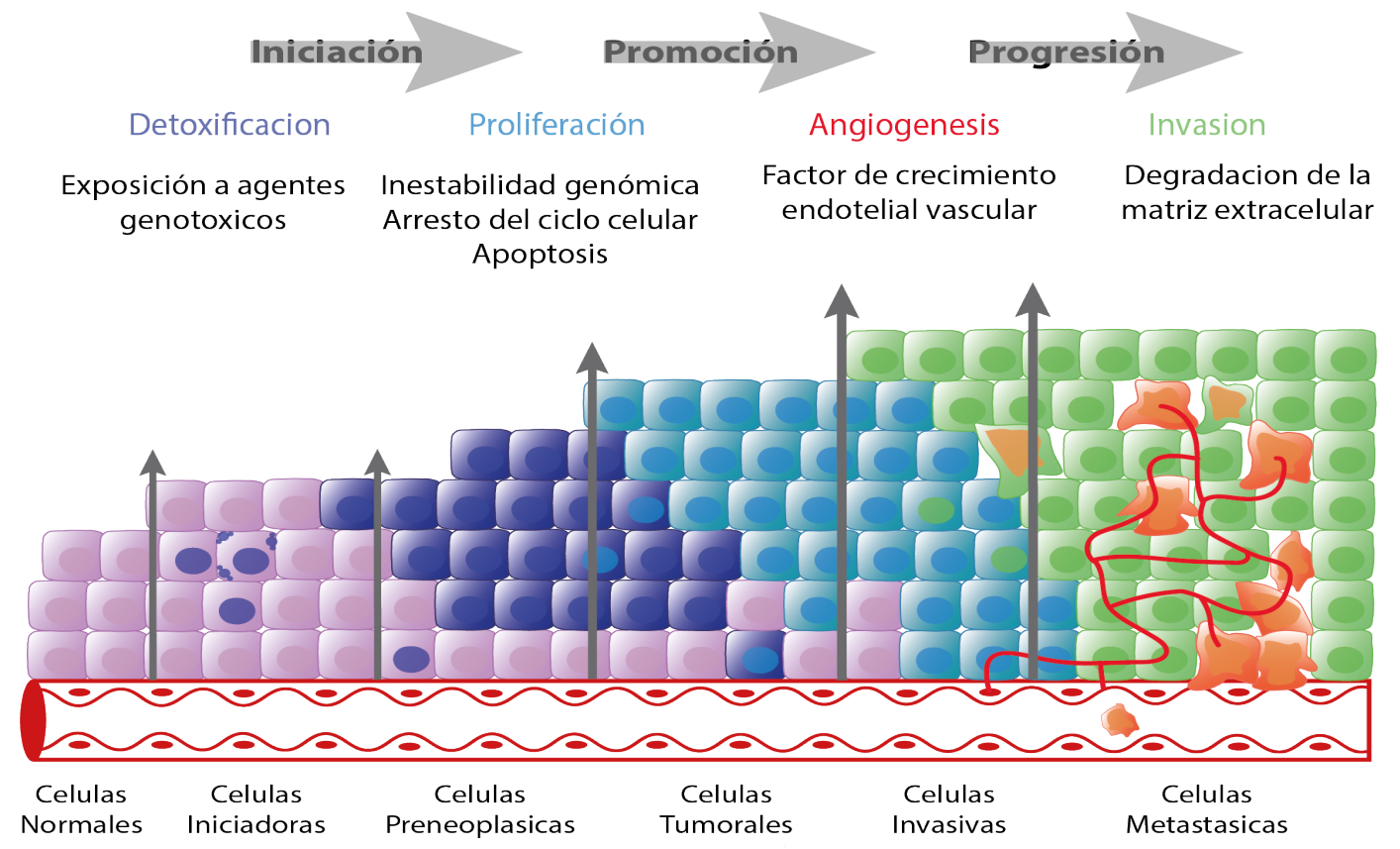

Figura 4. Procesos de establecimiento de la tumorigénesis. Para que se lleve a cabo de manera existosa es imporante que existan secuencialmente mecanismos de iniciación, promoción y progresión; para que éstos se presenten necesitan de la activación de diversas moléculas con acción pro-tumorigénicas y a su vez del silenciamiento de algunas otras con actividad antiproliferativas. Tomado y modificado de Min-Hsiung et al., 2011. 
Otra respuesta al estrés, asociada al daño irreparable del DNA, la proliferación incontrolada o el desprendimiento de matriz es la muerte celular apoptótica (Figura 5) (Ljungman, 2009). La apoptosis, consiste en una cascada de señalización que se divide en dos vías principales, extrínseca e intrínseca; este mecanismo se desencadena por moléculas solubles que se unen a los receptores de la membrana plasmática o por diversos estímulos mitocondriales. La vía apoptótica extrínseca se activa por receptores de muerte (RD; por sus siglas en inglés), que son receptores de superficie celular que se unen a ligandos específicos y transmiten señales apoptóticas, éstos ligandos incluyen moléculas solubles de la familia del Factor de Necrosis Tumoral (TNF; por sus siglas en inglés) y que se unen a miembros de la familia del receptor del TNF (TNF-R; por sus siglas en inglés), incluidos los receptores TNFR-1, Fas/CD95 y TRAIL DR- 4 y DR-5. La unión del ligando provoca la trimerización del receptor y la posterior activación (Ouyang et al., 2012)(Naudé, den Boer, Luiten, \& Eisel, 2011). Estas proteínas se unen a las caspasas iniciadoras (Lee, Seo, Jeong, Lee, \& Song, 2012), lo que permite la homodimerización y la activación posterior del complejo de señalización (DISC; por sus siglas en inglés) (Pennarun et al., 2010). Después de la activación de las caspasas 8 y 10 y las caspasas efectoras 3,6 y 7 se escinden, lo que conduce a la degradación celular en la etapa final de la apoptosis (Chowdhury, Tharakan, \& Bhat, 2008). Por otro lado la vía apoptótica intrínseca es iniciada por diversos estímulos intracelulares, incluyendo estrés oxidativo, daño en el DNA, hipoxia y privación del factor de crecimiento, que inducen la permeabilización de la membrana mitocondrial externa (Galluzzi, Kepp, \& Kroemer, 2012). La integridad mitocondrial puede ser controlada por varios miembros 
de la superfamilia Bcl-2, de los cuales hay dos subcategorías: pro-apoptótica y antiapoptótica. Bax, Bid, Bak, Bad, Noxa y PUMA son miembros de la familia proapoptótica, mientras que $\mathrm{Bcl}-\mathrm{xL}, \mathrm{Bcl}-2, \mathrm{Mcl}-1$ y $\mathrm{A} 1$ son miembros de la familia antiapoptótica (Martinou \& Youle, 2011).

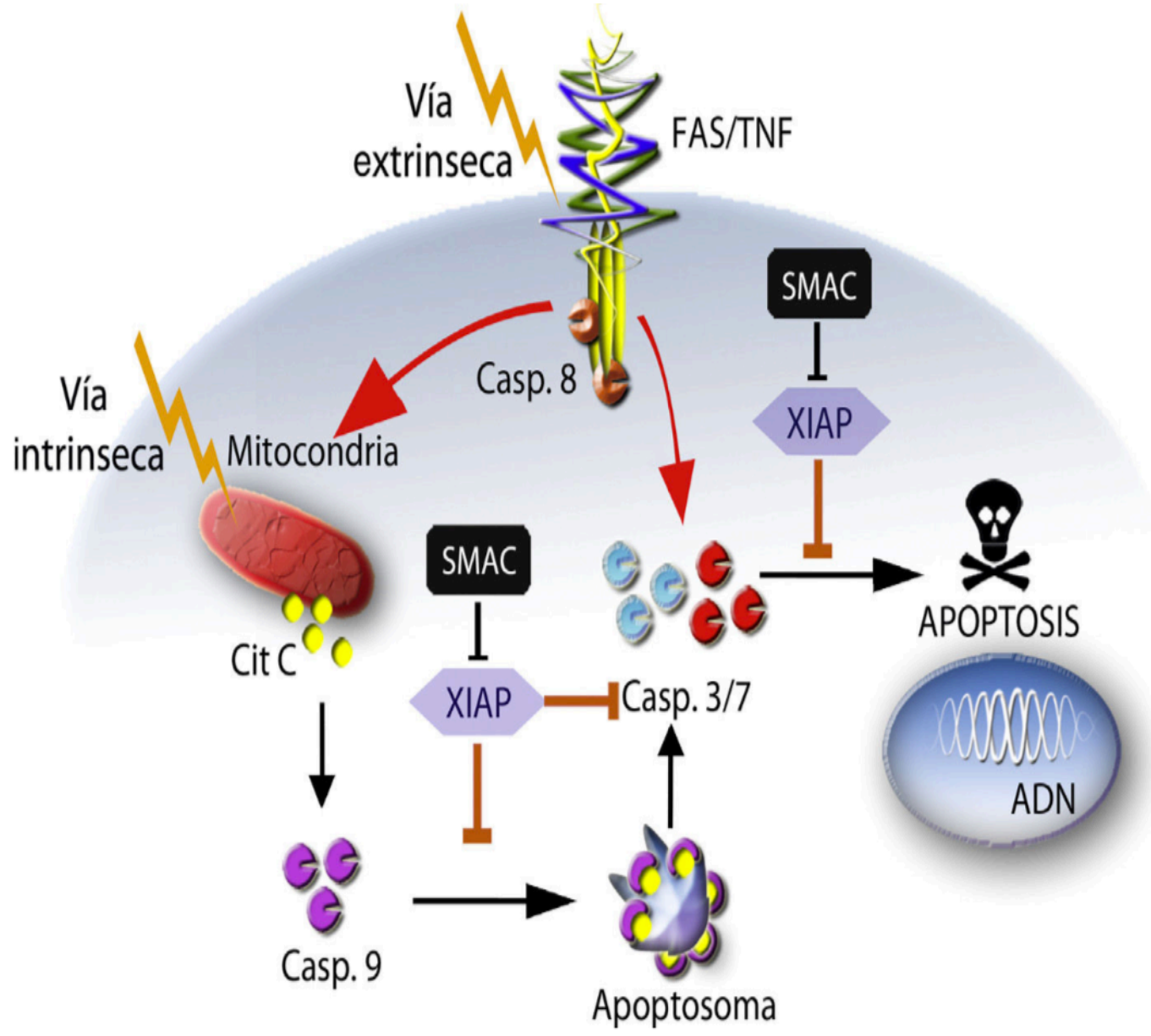

Figura 5. Proceso de muerte celular por Apoptosis. Muestra las vías intrínseca que se da a través de daño mitocondrial y extrínseca, a través de receptores de muerte (FAS/TNF). Independientemente del estimulo al que se someta la célula, en ambos casos converge en la activación de las caspasas efectoras 3/7 que conllevan a la inducción de apoptosis. Tomado y modificado de Muñóz y Cuca; 2016. 
Otro tipo de muerte celular ampliamente conocido es la autofagia (Figura 6), es un proceso de reciclaje de componentes intracelulares que fisiológicamente cumple una función de control de calidad, opera a una tasa basal baja, elimina proteínas patológicas de larga vida o mal plegadas y organelos dañados. Se regula positivamente como una respuesta protectora a una variedad de estrés que incluyen patógenos, metabólicos y genotóxicos (Nakatogawa \& Ohsumi, 2014). Es un proceso catabólico evolutivamente conservado y multifacético de autodegradación, que es importante para equilibrar las fuentes de energía en momentos críticos del desarrollo y en respuesta al estrés nutricional; también desempeña un papel de eliminación de proteínas de vida larga y mal plegadas o agregados de organelos dañados, como las mitocondrias, el retículo endoplásmico y los peroxisomas, asi como también de la eliminación de patógenos intracelulares. Generalmente es considerado como un mecanismo de supervivencia, aunque su desregulación se ha relacionado con la muerte celular no apoptótica (Glick, Barth, \& Macleod, 2010). Este consiste en la formación de células unidas para formar membranas citoplásmicas de doble capa conocidas como fagoforos, que maduran en autofagosomas completos. Los autofagosomas engullen proteínas de larga vida y orgánulos citoplasmáticos dañados para ser liberados por la maquinaria lisosomal para proporcionar energía celular en forma de ATP que es empleada en la biosíntesis de macromoléculas (Zhu et al., 2009). La maquinaria autofágica central se regula a través de un grupo de genes llamados: genes relacionados con autofagia, abarca solo los ATG ; (por sus siglas en inglés AuTophaGy), son necesarios para la formación del autofagosoma en 
todos los subtipos y estos se pueden dividir en varios grupos distintos: (1) el complejo quinasa unc 51-like 1/2 (ULK 1/2) (2) la proteína de membrana multicanal Atg9, (3) el complejo PI3K-III y (4) los sistemas de conjugación de cadena ligera-3 alfa (MAP1LC3A), 3 alfa de cadena asociada a ubiquitina (MAP1LC3A) asociada a ubiquitina y ATG12 similar a ubiquitina (Fujioka et al., 2014).

El proceso de autofagia se ejecuta a niveles basales en prácticamente todas las células como un mecanismo homeostático para mantener la integridad celular. Es inducida por la disminución de los nutrientes, así como también en la eliminación de proteínas mal plegadas o agregados celulares; de esta forma elimina organelos dañados como mitocondrias, retículo endoplasmático y peroxisomas (Glick et al., 2010). Aunque en algunos casos la autofagia puede desempeñar un papel en la ejecución de la muerte celular, es un mecanismo citoprotector a la deprivación de nutrientes, en el mantenimiento de la homeostasis y evita la inestabilidad genómica; por esta razón, tiene un papel clave en las terapias anticancerígenas (Xu, Wang, Tan, \& Jing, 2012). Se clasifica en 3 tipos principales: microautofagia, autofagia mediada por chaperonas y macroautofagia (Sujit K. Bhutia et al., 2013) siendo esta última la más importante en la biología del cáncer y sus terapias (M. K. Kim et al., 2012). La macroautofagia se trata de la formación de una vesícula de doble membrana -el autofagosoma- el cual envuelve a los componentes citoplasmáticos y se fusiona con los lisosomas formando el autolisosoma que contiene enzimas hidrolasas para su posterior reciclaje y degradación (Kenific \& Debnath, 2015). Hay más de 30 genes relacionados con ella, siendo los principales los ATG 12, 5, 10, 7 , 
16, 4, y 3; éstos son activados por respuestas a estrés como falta de nutrientes y en diferentes fases como son: en iniciación, nucleación, elongación y cierre, fusión, degradación y reciclaje. (Glick et al., 2010).

El primer paso es la nucleación del fagoforo; el estrés celular inactiva al sensor de estrés o mTOR, lo que resulta en hipofosforilación de Atg13, que con la ayuda de Atg17 se une a Atg1 (homólogo de mamífero de ULK1) y posteriormente, Atg1 recluta activamente Atg9, el cuál extrae lípidos de diversas fuentes, incluidos los endosomas, aparato de Golgi, núcleo y el retículo endoplásmico (RE). Después de la nucleación, el fagoforo naciente se alarga y madura a través de la acción del fosfatidil inositol ( $\mathrm{PI}$ ) 3-cinasa clase III ( $\mathrm{PI} 3 \mathrm{~K}$; por sus siglas en inglés), y de la proteína vesicular 34 (Vps34; por sus siglas en inglés), que interactúa con Beclina-1 (homólogo de mamífero de Atg6 de levadura) y recolecta fosfatidil inositol-3-fosfato (PI3P) (Simonsen \& Tooze, 2009). PI3P actúa como un estímulo de localización que facilita la fusión durante el paso final de la síntesis de autofagosomas de doble membrana. La interacción entre Vps34 y Beclina-1 es promovida por la activación de la proteína autofagica 1 regulada por Ambra, el gen asociado a la resistencia de la radiación ultravioleta (UVRAG) y el factor 1 que interactúa con Bax (Bif-1). Por el contrario, Bcl-2, Bcl-xL y el dominio de Beclina-1, interactúa con la proteína rica en cisteína (Rubicon) para inhibir su interacción (Funderburk, Wang, \& Yue, 2010). Se conocen 2 sistemas de conjugación tipo ubiquitina, están asociados con la formación de autofagosomas y contribuyen al alargamiento de las vesículas. En un proceso en cascada, Atg12 se une a Atg7 (enzima activadora de tipo ubiquitina E1) de una 
manera dependiente de ATP; después, Atg12 se une a Atg10 (ubiquitina similar a E2), que une Atg12 a Atg5; a continuación, los dímeros Atg16 se conjugan con este complejo y ayudan a la formación del fagoforo en expansión (Nakatogawa, 2013). El complejo trimerico: Atg5-Atg12-Atg16, se disocia cuando el fagoforo se convierte en el autofagosoma (Shpilka, Weidberg, Pietrokovski, \& Elazar, 2011). El sistema de tipo ubiquitina procesa la cadena ligera 3 asociada a microtúbulos (homólogo de mamífero de Atg8) (LC3; por sus siglas en inglés); a continuación, una proteína cinasa de cisteína, Atg4 (también denominada autofagina), escinde LC3 para dar lugar a LC3I y conjuga Atg7 de tipo E1 a través de un mecanismo dependiente de ATP, estimulando de este modo LC3I. Luego, el transportador similar a E2 se asocia con LC3I activado, que culmina en lipidación, lo que da lugar a LC3-I fosfatidiletanolamina (conjugado de PE o LC3II). La membrana de fagoforo creciente interactúa selectivamente con agregados de proteínas y orgánulos. Curiosamente, LC3-II desempeña un papel importante como receptor en la membrana de fagoforo e interactúa con restos de adaptadores presentes en agregados de proteínas y mitocondrias dañadas, promoviendo así su absorción selectiva y degradación (Tanida, Ueno, \& Kominami, 2008).

Inicialmente, la vía autofágica funciona como una respuesta adaptativa al estrés. Sin embargo, frente al estrés extremo o prolongado, las células se comprometen a someterse a la muerte celular autofágica (Sujit K. Bhutia et al., 2013). El control de la autofagia mediante la señalización TORC1 es en gran parte responsable del potente efecto de la inanición como un inductor de autofagia. También se consideran las 
señales que influyen en la autofagia independientemente de TOR, con el objetivo de considerar cómo los pasos específicos de la inducción de autofagia pueden verse influenciados por señales moleculares distintas. En conjunto, estos hallazgos apuntan a los complejos Beclina 1/Vps34 como potenciales objetivos comunes de múltiples señales de autofagia independientes de TOR. Como se discutió anteriormente, las señales mediadas por TOR y mediadas por Atg1 también parecen actuar río arriba de este complejo. La sobreexpresión de los componentes de este complejo puede ser suficiente para inducir la autofagia (S. K. Bhutia et al., 2010), y las señales de estrés por disponibilidad de nutrientes parecen regular la actividad de Beclina-1/Nps34 a través de una vía dependiente de Jun (Funderburk et al., 2010). Recientemente se ha sugerido la activación de Vps34 en regiones discretas del retículo endoplásmico para determinar la ubicación de los sitios de ensamblaje para la formación del autofagosoma (Perl, 2015). 


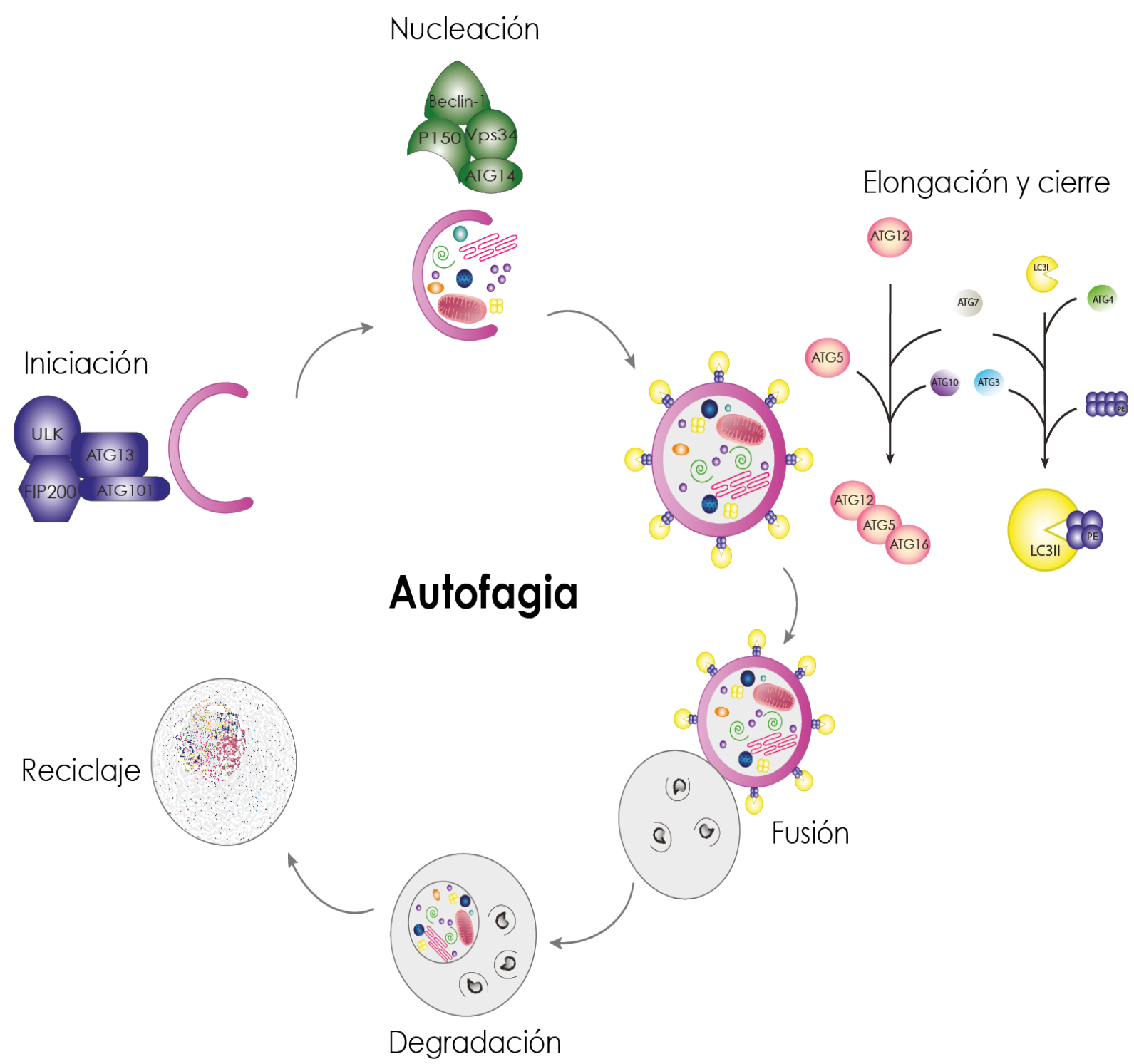

Figura 6. Proceso de regulación de Autofagia.Muestra el proceso de formación del autofagosoma a través de diferentes complejos, llevando a la fusión y degradación de los componentes citoplasmáticos; la participación de los genes reguladores de autofagia, juegan un papel importante en éste mecanismo de degradación (Tomado de DelgadoWaldo 2016 y modificado de (Fu, Wen, Bao, \& Liu, 2012). 


\section{CANCER DE MAMA}

\subsection{Anatomia de la mama}

La mama es un tejido cuya función principal es la síntesis y secreción de la leche, se encuentra más desarrollado en mujeres a partir de la pubertad y se localiza en la fascia pectoral profunda que cubre el músculo pectoral mayor. Contiene una red ramificada de conductos y lóbulos embebidas en una matriz de soporte de tejido conectivo y grasa (Ellis \& Mahadevan, 2013). Cada mama se compone principalmente de estructuras externas e internas; las externas son el pezón y la areola, mientras que las internas se componen principalmente de tejido adiposo, conectivo, conductos y glándulas mamarias. Las glándulas mamarias contienen de 15-25 conductos lactíferos localizados en el pezón, estos se ramifican en ductos más pequeños y terminan en la unidad lobular ductal terminal (lóbulo) que constan de un ducto terminal y varios ductulos o acinos (Farshid, 2014). Los ductos y ductulos están revestidos por una capa interna de células epiteliales cúbicas a columnares y una capa externa de células mioepiteliales (Moumen et al., 2011).

El epitelio mamario se compone de dos capas celulares: luminales y basales mioepiteliales; (productoras y excretoras de leche durante la lactancia). (Gudjonsson, Adriance, Sternlicht, Petersen, \& Bissell, 2005). En la etapa adulta durante el embarazo el desarrollo se regula por la acción de progesterona que inducen la proliferación y la ramificación de los conductos y prolactina (hormonas esenciales

para el desarrollo y homeostasis de la mama) generando los alveolos para la 
secreción de leche. (Tanos, Rojo, Echeverria, \& Brisken, 2012). Los receptores de progesterona y de estrógeno se expresan principalmente en células luminales mientras que las células basales no expresan estos receptores. Estas características dan lugar a diferentes tipos celulares (Figura 7) (Gudjonsson et al., 2005)

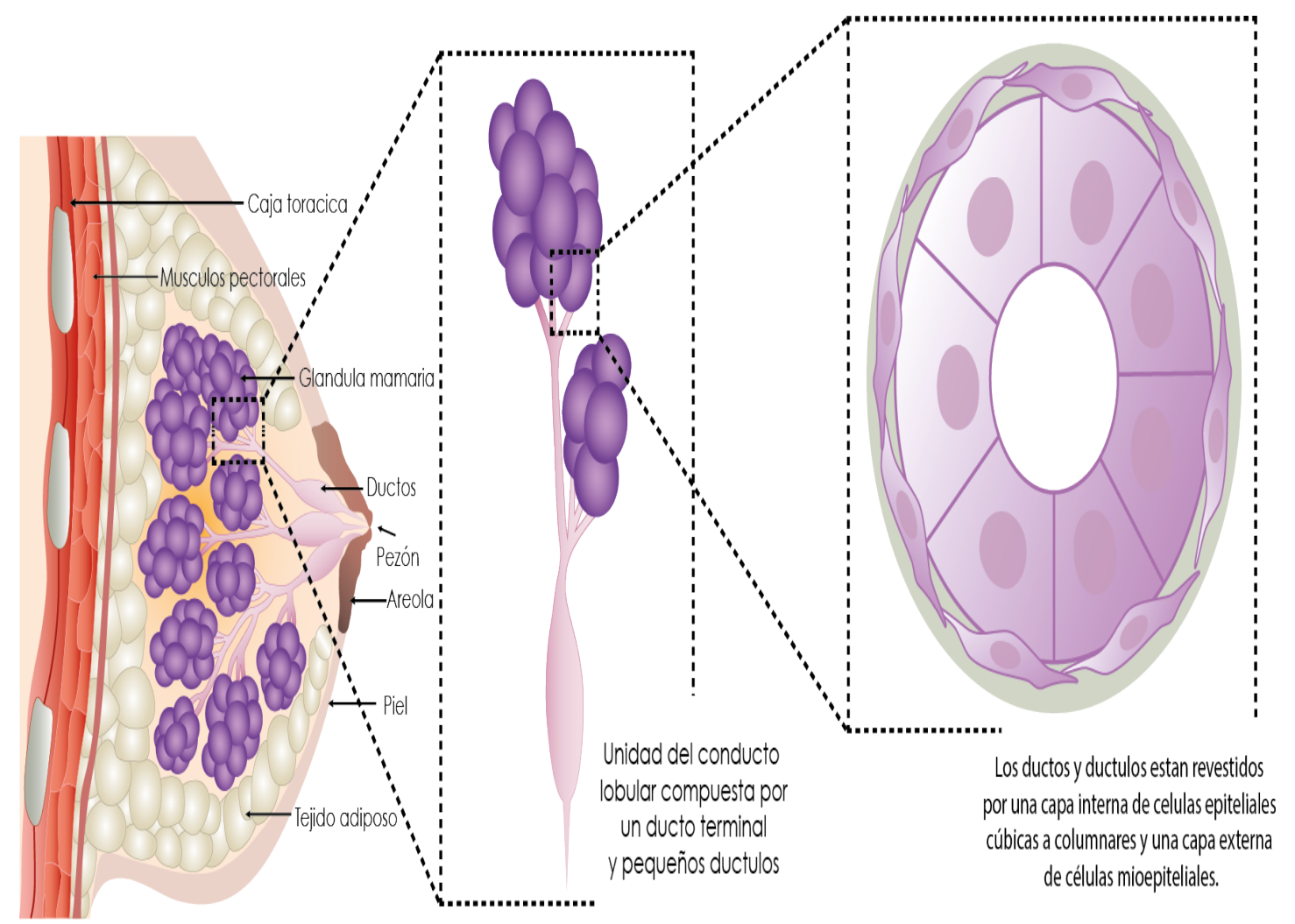

Figura 7. Estructura básica de la mama. Se muestran la piel, pezón, areola, tejido graso, conectivo y la glándula mamaria, que contiene 15-25 conductos lactíferos localizados en el pezón. Estos se ramifican en ductos más pequeños terminan en la unidad lobular ductal terminal (lóbulo), que esta compuesta por un ducto terminal y varios pequeños ductulos (o acinos). Los ductos y ductulos están revestidos por una capa interna de células epiteliales cúbicas a columnares y una capa externa de células mioepiteliales. Tomado y modificado de (Gjorevski \& Nelson, 2011). 


\subsection{Incidencia y mortalidad de cáncer de mama}

El CaMa es la manifestación oncológica con mayor incidencia y mortalidad en mujeres en todo el mundo, afecta principalmente a mujeres entre 30 y 59 años de edad. En el 2012 se reportó a nivel mundial un 29\% de nuevos casos de cáncer, de los cuales, el $14 \%$ corresponde a muertes relacionadas en mujeres en todo el mundo; esto aproximadamente corresponde a 1,7 millones de nuevos casos en mujeres y aproximadamente 522,000 de muertes (Ferlay et al., 2015). Los principales factores de riesgo para el CaMa incluyen la edad, la historia familiar de CaMa, la

predisposición genética (por ejemplo, mutaciones en los genes BRCA), menarquia temprana y menopausia tardía (55 años de edad o más), primer embarazo a término después de 30 años de edad, corto período de lactancia, mala alimentación (dieta baja en fibra), la adiposidad (índice de masa corporal $>30$ ), el consumo de alcohol, baja o nula actividad física, terapias de remplazo hormonal en la menopausia, entre otros (Cabrera-Gaytán et al 2008). En los últimos veinte años, la incidencia y mortalidad por CaMa ha aumentado en los países en desarrollo, especialmente entre las mujeres más jóvenes.

En México, se registraron 13,939 nuevos casos y 4,500 casos de muertes por CaMa en 2008 (Jemal et al; 2010). Estudios realizados por la Fundación Mexicana de Salud, reportaron que a partir del 2006, en mujeres, el riesgo de morir por éste tipo de cáncer en nuestro país excedió el riesgo de morir por cáncer cérvico-uterino, 
posicionando al CaMa como la principal causa de muerte por enfermedades oncológicas en México (Figura 8) (Knaul et al; 2009).

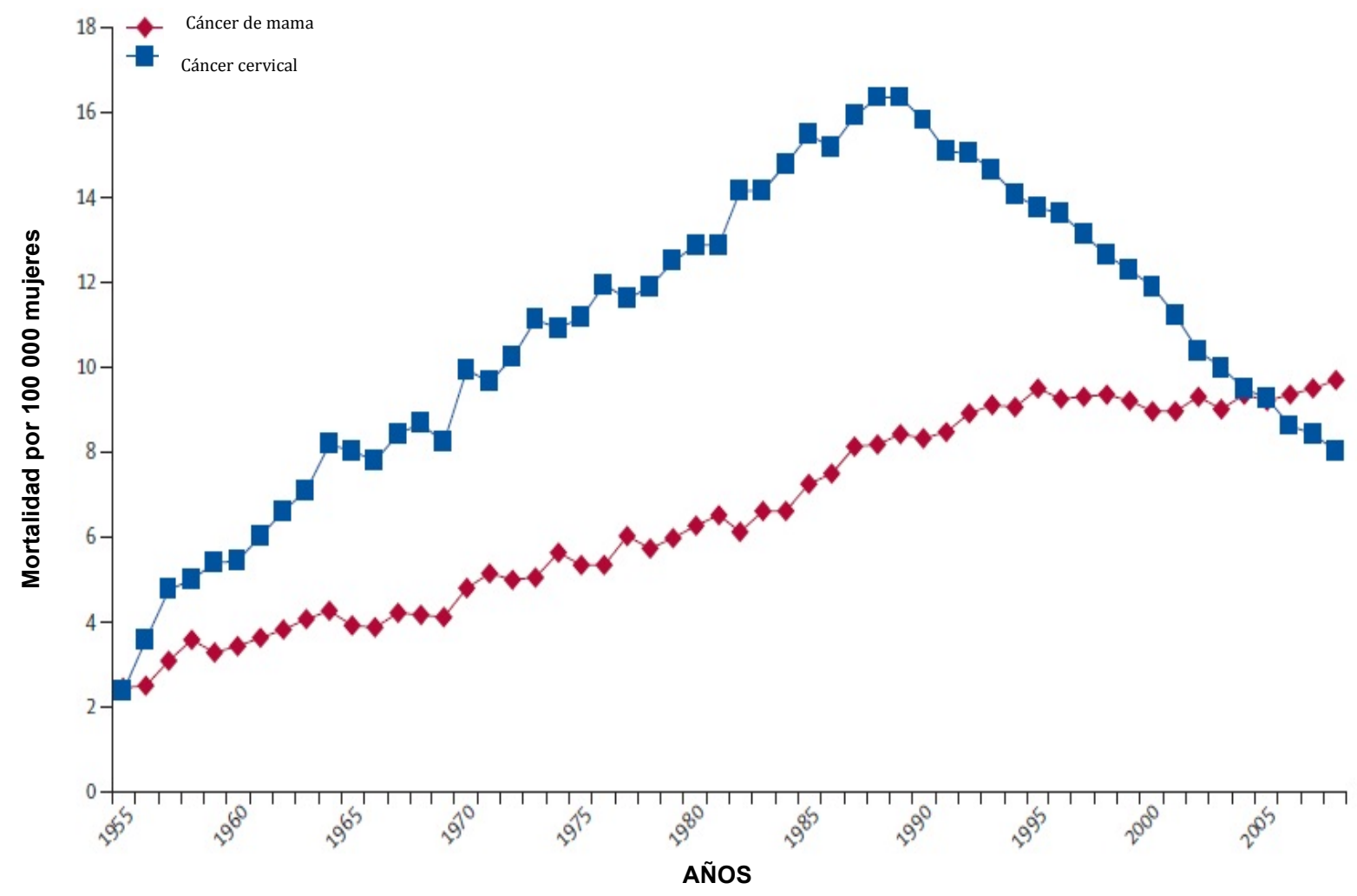

Figura 8. Mortalidad por cáncer cervico-uterino y mama en nustro país. En el año 2005 la mortalidad por cáncer cérvico-uterino supero la mortalidad por cáncer de mama en el periodo de 1995-2005 en mujeres mexicanas, colocándose en la primera causa de muerte en nuestro país. Tomado de Chávarri-Guerra et al; 2012.

Por otra parte México en una escala a nivel mundial tiene una incidencia y mortalidad por CaMa baja, la incidencia se ha triplicado en los últimos 6 años y se espera que esta tendencia continúe en el futuro (Cabrera-Gaytán et al; 2008). Según el INEGI, datos reportados en el 2010, 19 de cada 100 mujeres que ingresan a la atención hospitalaria lo hacen debido a neoplasias malignas mamarias (INEGI., 2013). Casi la 
mitad de los casos (45.5\%) ocurren en mujeres menores de 50 años de edad, en contraste con la incidencia de CaMa de Estados Unidos, donde sólo el 25\% de los casos son mujeres pre-menopáusicas (Martínez-Montañez, Uribe-Zúñiga, \& Hernández-Avila, 2009). Existen evidencias de que la edad promedio de inicio de la enfermedad es menor en los países en desarrollo que en los más desarrollados; sin embargo en la actualidad se ha reportado que esta enfermedad afecta a todos los grupos poblacionales (Beasley et al., 2010). Este aumento en la incidencia del CaMa se ha asociado a la consecuencia de la adquisición del tipo de vida "occidental" (dieta alta en calorías, la falta de ejercicio físico, alto consumo de grasa animal). Estás observaciones sugieren que los factores ambientales y el estilo de vida, particularmente la alimentación, juegan un papel fundamental en la evolución de ésta neoplasia (Ortiz-Rodríguez et al; 2008). Por lo tanto, el CaMa en el siglo XXI no es necesariamente terminal, ya que cada día los avances científicos implementan importantes mejoras en las opciones terapéuticas y las pruebas diagnosticas en la salud pública y la atención, lo que a ayudado a reducir de manera dramática la mortalidad por CaMa. Sin embargo lamentablemente se pronostica que para el 2030 cerca de 24,386 mujeres serán diagnosticadas con CaMa y 9,778 (40\%) morirán por ésta enfermedad en México; siendo un reto importante para los Servicios de Salud (Chávarri-Guerra et al., 2012). 


\subsection{Cáncer de mama}

El CaMa es una enfermedad caracterizada por el crecimiento descontrolado de células malignas en el tejido epitelial mamario, causada por la interacción entre factores genéticos y externos (físicos, químicos y biológicos) que producen degeneración celular, dando paso a las lesiones precancerosas y finalmente a tumores malignos que en caso de promover metastástasis puede transferirse a órganos distantes como el hueso, el hígado, el pulmón y el cerebro; desafortunadamente las opciones para su tratamiento en estado metastásico avanzado son limitadas (Lukong, 2017). Diversos estudios sustentan que el CaMa tiene una relación causal con el estado hormonal y se sabe que proximadamente el $80 \%$ de los carcinomas son ductales y el resto lobulillares (Chávarri-Guerra et al; 2012); los infiltrantes representan el $15 \%$ de los subtipos que existen y en su mayoría son de mal pronóstico, ya que presentan un alto índice de proliferación celular (Figura 9) (Rakha et al; 2007). 
a)

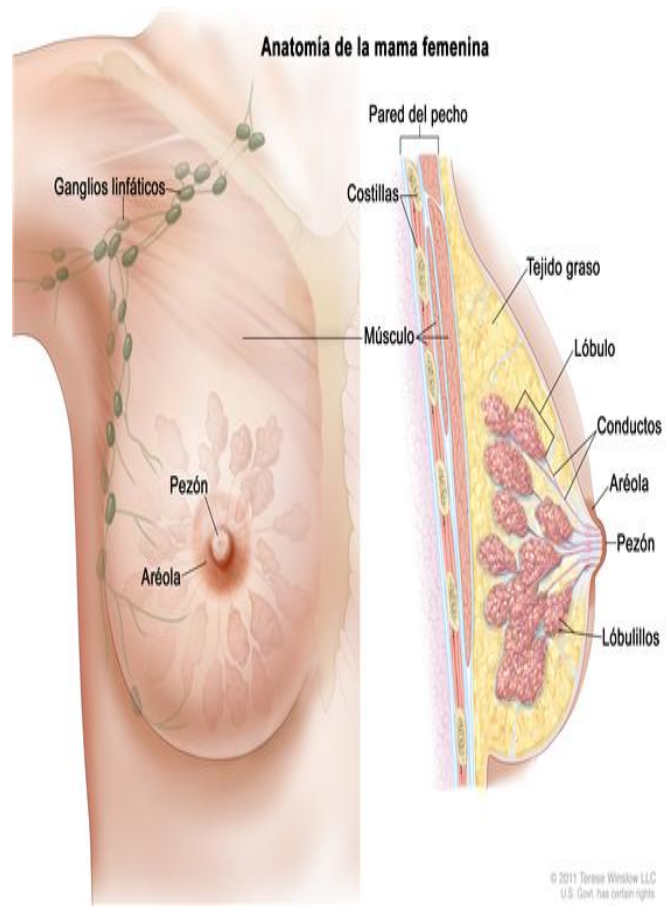

b)

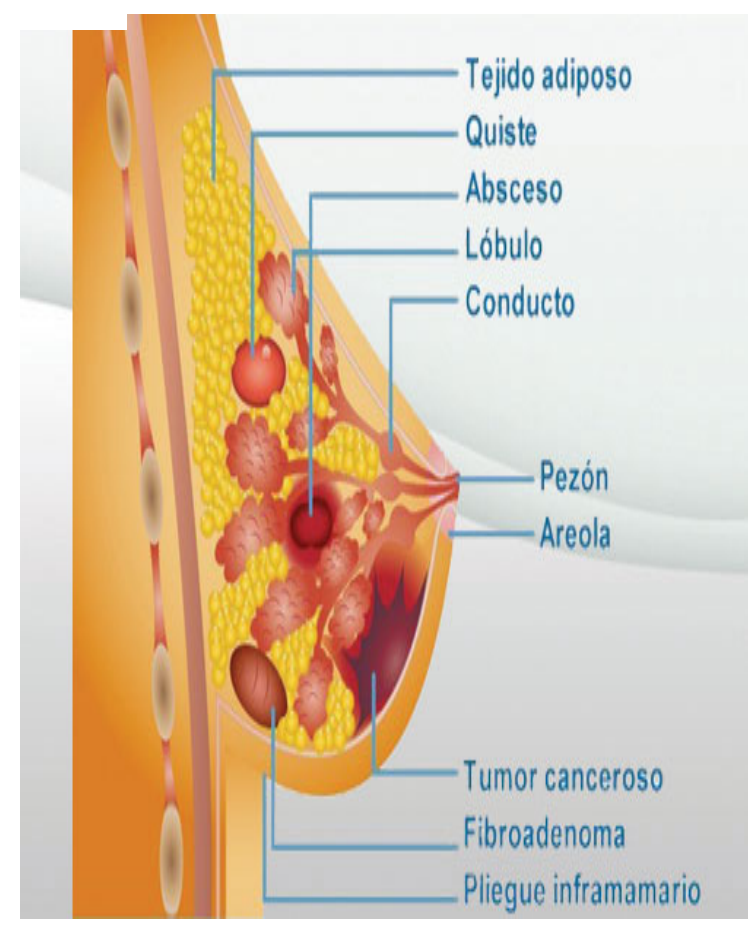

Figura 9. Establecimiento de células tumorales en la glándula mamaria. a) anatomía de la glándula mamaria en estadio y b) el CaMa es el crecimiento descontrolado de células malignas en el tejido mamario, puede diseminarse a otras zonas del organismo. El carcinoma ductal; es más común y comienza en los conductos que transportan leche; el lobulillar: inicia en los lóbulos que producen leche. Algunos cánceres se originan en las células que recubren los ductos (cáncer ductal); otros en las células que recubren los lobulillos (cáncer lobulillar). Modificada de Gjorevski y Nelson, 2011.

\subsubsection{Subtipos de cáncer de mama}

La clasificación molecular del CaMa, como se muestra en la Figura 10, se basa en los perfiles de expresión génica, pues aunque aparentemente los tumores son de morfología homogénea, tienen características biológicas que particularmente afectan la respuesta a los tratamientos (Badve et al; 2011). La expresión de perfiles de tumores mamarios humanos reveló subtipos moleculares de distintas firmas de 
genes con alto valor pronostico-predictivo. Como una nueva forma de clasificar los cánceres de mama, en el 2000, Perou y colaboradores basados en una lista de 496 genes intrínsecos que obtuvieron con base en estudios sobre perfiles de expresión génica lograron la identificación de 4 subgrupos que diferencian los cánceres de

mama en función de sus patrones de expresión génica. Ésta clasificación ésta representada por: Tipo Basal (HER-2+), Luminal A y B, y Basal-like (TN); éstos subtipos difieren notablemente en su pronóstico y en la expresión o ausencia de sus receptores hormonales (Masood, 2016).

Todos estos subtipos son histológicamente diferentes y tienden a variar en sus resultados clínicos; por ejemplo, el subtipo luminal A es histológicamente de bajo grado y tiene el pronóstico más favorable, mientras que los tipos luminal $\mathrm{B}$, a menudo son de alto grado y más agresivos; los HER-2 (+) son de alto grado y se asocian con un mal pronóstico y el basal-like o Triple Negativo (TN) es el carcinoma de mama biológicamente más agresivo, representa el peor pronóstico de los demás subgrupos, pues la mayoría de las muertes se producen en los primeros 5 años después del diagnóstico (Yadav, Sharma, Chanana, \& Jhamb, 2014).

\subsubsection{HER-2 (+)-enriquecido}

El fenotipo Basal o clínicamente conocido como positivo para el Receptor del Factor de Crecimiento Epidérmico Humano-2 (por sus siglas en inglés, HER-2+), representa aproximadamente del $15 \%-20 \%$ de todos los tumores de CaMa, y la mayoría de ellos 
presentan altas tasas de éxito terapéutico y periodos libres de recurrencia; HER-2 es un receptor de tirosina cinasa que transmite señales para promover diversos procesos celulares, incluida la proliferación celular. El blanco para el tratamiento de este fenotipo se basa en la inhibición de la tirosina cinasa que interrumpe la vía del receptor de crecimiento HER-1 y HER-2 y por lo tanto, suprime la señalización por estos receptores. Para ello es ampliamente conocido el uso de trastuzumab, lapatinib o la combinación de ambos; éste último aprobado como terapia de primera línea. El Lapatinib, conocido por su nombre comercial como Tykerb fue aprobado por la Food and Drug Administration (por sus siglas en inglés, FDA) en el 2007 para pacientes HER-2 (+) y es una opción para aquellos pacientes que no responden al tratamiento con Herceptin; los efectos secundarios en los pacientes con éstos tratamientos pueden sufrir moderado daño cardiaco, náuseas y toxicidad pulmonar. (Rimawi, Schiff, \& Osborne, 2015).

Recientemente, en el 2010, el proyecto CLEOPATRA (Evaluación Clínica de Pertuzumab y Trastuzumab), un ensayo internacional y aleatorio de fase III, controlado con placebo, consistió en el reclutamiento de aproximadamente 800 pacientes HER-2 (+) de alrededor de 250 centros en todo el mundo. Éste proyecyo consistió en evaluar la efectividad de la combinación de docetaxel-trastuzumab (Herceptin) y pertuzumab-docetaxel-trastuzumab en el tratamiento del CaMa (Lukong, 2017). Estas combinaciones farmacológicas, representaron la primera de una nueva clase de medicamentos llamados "inhibidores de dimerización HER", que se unen a HER-2 (+) e inhibe su homo y heterodimerización, mostrando que la 
combinación de pertuzumab con trastuzumab y docetaxel, retrasó considerablemente el crecimiento de los tumores mamarios metastásicos HER-2 (+), mejorando significativamente la sobrevivencia libre de progresión en comparación con la combinación de un placebo con Herceptin y docetaxel (Nagini, 2017). Debido a que el uso de estas combinaciones no se asoció con ningún efecto secundario grave, esta combinación farmacológica se logró establecer como terapia de primera línea, representando un progreso sustancial en el estándar de atención para pacientes HER-2 (+). Estos resultados impulsan y sustentan la efectividad de combinar dos o más fármacos que se dirigen a la misma vía de señalización y la baja eficacia de aquellas terapias que se emplean de manera adyuvante (Swain et al., 2015) y (Swain et al., 2013) .

\subsubsection{Luminal A y B}

Estos subtipos de CaMa luminal representan alrededor de dos tercios de todos los casos a nivel mundial; desde hace tiempo se ha establecido que los tumores luminales son heterogéneos en términos de nivel de perfil de expresión génica, histología y respuesta al tratamiento. Los subtipos luminal A y luminal B se caracterizan por ser positivos para RE (Receptores de Estrógeno), presentar baja expersión de RP y nula expresión de HER-2; tambén incluyen la expresión de GATA3. Estos subtipos, a diferencia del HER-2+ y el Basal-Like (TN), generalmente tienen un buen pronóstico y muestran una respuesta favorable a la terapia endocrina. Sin embargo el Luminal A tiene un mejor pronóstico y bajas tasas de recurrencia 
(Metzger-Filho, Winer, \& Krop, 2013) que el Luminal B, el cual presenta tasas de proliferación más altas y menor expresión de los RP (Receptores de Progesterona) (Charles M. Perou et al., 2000) y mutaciones asociadas con TP53 e inestabilidad genética; al rededor del $20 \%$ del total de los tumores de CaMa corresponden con este fenotipo y tienden a tener un pronóstico más precario que los tumores Luminal A (Haque et al., 2012). Cuando se compara el subtipo luminal A con el luminal B, los tumores luminales B representan un mayor grado tumoral, mayor expresión de genes relacionados con la proliferación y activación de las vías de señalización del receptor del factor de crecimiento (GFR), tales como IGF-1R y PI3K/AKT/mTOR. Además se considera que los tumores Luminal $B$ tienen una sensibilidad más baja al tratamiento endocrino y mayor sensibilidad a la quimioterapia que los tumores luminales $A$ (Ignatiadis \& Sotiriou, 2013).

El tratamiento de primera línea para pacientes con éstos fenotipos es el Tamoxifeno, que funciona como un modulador selectivo de receptores estrogénicos. El mecanismo de acción se basa en su efecto antiestrogénico, es decir, bloquea la acción de esta hormona que estimula el desarrollo de las células tumorales. Dentro de los efectos secundarios del Tamoxifeno se sabe que puede causar hiperplasia o carcinoma endometrial y también puede predisponer a los pacientes a la trombosis. El tratamiento de segunda línea aprobado en 2002, Fulvestrant, es esencialmente un antagonista farmacológico que se conoce como un anti-estrógeno y es un regulador selectivo del receptor de estrógenos (SERD); fue nombrado así porque se une 
directamente al RE. Su función es evitar la dimerización del RE y promover la rápida degradación del mismo. (Tian, Wang, Seiler, \& Hu, 2014).

\subsubsection{Basal o Triple Negativo}

El fenotipo de CaMa Basal o clínicamente referido como TN, se caracteriza por la ausencia de RE, RP y del oncogen HER-2/neu, es el grupo más estudiado debido a su alta herrogeneidad y comportamiento biológico diferenciado en comparación con los otros subtipos moleculares (Masood, 2016). Los tumores TN suelen ser los más agresivos y de bajo éxito terapéutico, se asocian con pobre pronóstico y tiene una historia clínica agresiva con alto grado patológico, periodos cortos de sobrevivencia y recurrencia de la enfermedad. Representan del $10 \%$ al $25 \%$ de todos los tumores mamarios (Figura 10) (Mc Carthy et al; 2012) y a diferencia de los subtipos luminales y HER-2+, son altamente metastásicos e invaden ganglios linfáticos con mayor facilidad (Chen et al; 2012). Como perfil característico, los tumores TN alcanzan un gran tamaño debido al alto nivel de expresión de Ki67 y citoqueratinas de alto peso molecular como: CK5 o CK5/6, CK14, CK17 y EGFR, CKIT, P63 y P-Caderina, lo que promeve una alta tasa mitótica y actividad proliferativa (Badve et al., 2011). Desde una perspectiva biológica se ha observado que los tumores TN presentan zonas celulares centrales que se encuentran compuestas por material hialino, tejido necrótico e isquémico y colágeno, estos tumores a menudo tienen bordes no infiltrantes y pueden mostrar grado de infiltrado linfo-plasmacítico con características medulares (Makki, 2015), lo que hace pensar que los tumores basales se derivan de 
un tipo de célula o etapa distinta al desarrollo de las células epiteliales mamarias, esto lo hace un fenotipo difícil de estudio debido a su alta heterogeneidad (Curtis et al., 2012).

Sin embrago, con el paso de los años diversos grupos de investigación a través de ensayos inmunihistoquimicos y de microarreglos, han descubierto características importantes de éste subtipo, como la presencia de las citoqueratinas antes mencionadas y del EGFR que se asocian a un pobre pronóstico o bien la deficiencia de $\mathrm{Rb}$ y p53 que juegan un papel importante como reguladores críticos del ciclo celular; también se ha encontrado que estas células están asociadas con el estado de mutación de BRCA1, pues se ha observado que la mayoría de los portadores con mutaciones en BRCA1, desarrollan CaMa TN (Honrado, Benítez, \& Palacios, 2005). Se cree que ésta pérdida de $\mathrm{p} 53, \mathrm{Rb}$ y la asociación de la vía BRCA1 sean las responsables de la alta aneuploidía que se observa en estos tumores, incluido un gran número de cambios cromosómicos (C. M. Perou, 2011). Lo anterior hacen que el fenotipo TN presente distintos patrones de expresión génica e inmunocitoquímicas, lo que hace más difícil establecer un enfoque terapéutico específico disponible para éstos tumores (Dewar, Fadare, Gilmore, \& Gown, 2011).

El pronóstico de vida para los pacientes con CaMa TN es poco prometedor a diferencia de los fenotipos luminal y HER-2+; sin embrago diversos grupos de trabajo continúan tratando de identificar los mejores objetivos terapéuticos para estos pacientes (Prat \& Perou, 2010). Actualmente los pacientes TN sometidos a los 
protocolos clínicos presentan alto riesgo de recurrencia temprana que va de entre 1-3 años después de la cirugía y culmina con una mayor tasa de mortalidad a los 5 años después de la quimio y radioterapia (Young et al; 2009). Como tratamiento de primera línea se emplean las antraciclinas y taxanos (doxorrubicina-ciclofosfamida y docetaxel); lamentablemente el efecto de éstas quimioterapias en los pacientes TN presentan una tasa de respuesta patológica completa (RPC) muy baja, en éste caso del $7 \%$ y alto grado de toxicidad en los pacientes (Alcalá-Corona, de Anda-Jáuregui, Espinal-Enríquez, \& Hernández-Lemus, 2017). A pesar de que existen diversos ensayos clínicos para tratar de encontrar la terapia más adecuada, hasta la fecha no se ha logrado obtener una respuesta patológica completa a la quimioterapia sola o en combinación (Prat y Perou; 2009), pues las terapias farmacológicas existentes hasta el momento siguen siendo agresivas y poco exitosas. 


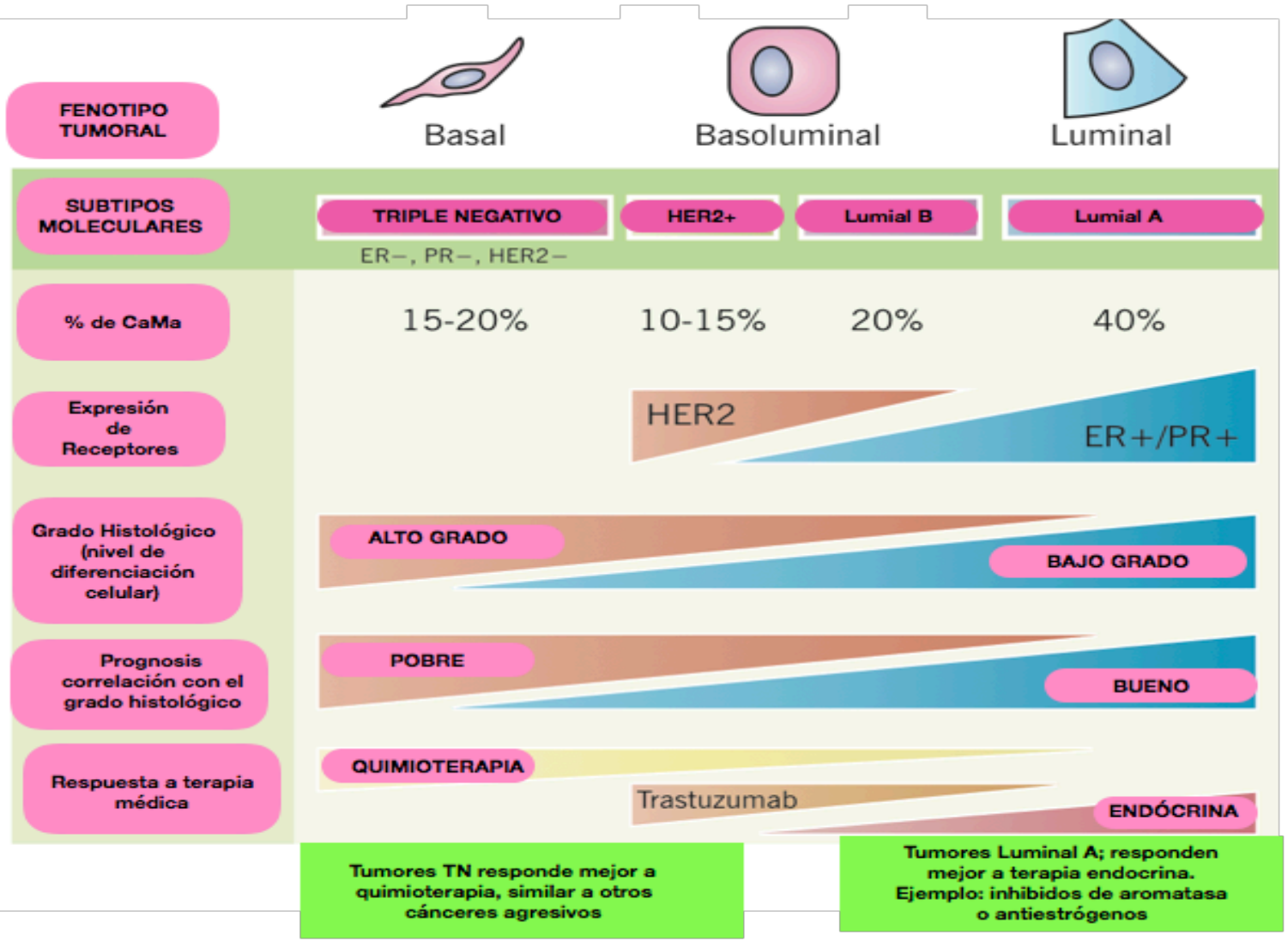

Figura 10. Subtipos de cáncer de mama. \% de incidencia de cada uno de ellos, tipo de receptores de cada uno de ellos, grado de riesgo, pronóstico, tipo de terapia y respuesta clínica. Observando que el fenotipo TN es el de alto riesgo, con pronóstico pobre, baja o nula respuesta terapéutica y comprende el $15-20 \%$ de los tumores. (Tomado y modificado de C.M.Perou, 2012).

\subsection{Factores de riesgo en CaMa}

Existen diversos factores de riesgo como el sexo, el envejecimiento, los estrógenos, los antecedentes familiares, las mutaciones genéticas y el estilo de vida que pueden aumentar la posibilidad de desarrollar CaMa (Majeed et al., 2014). La mayoría de los casos ocurre en mujeres y el número de ellos es 100 veces mayor que en hombres; actualmente se observa que la tasa de incidencia a nivel mundial aumenta año con año mientras que la tasa de mortalidad disminuye gracias a las pruebas de detección temprana y al desarrollo de las terapias médicas avanzadas han mostrado ser 
beneficiosas en cuanto a la disminución de la mortalidad en los últimos años (Siegel, Miller, \& Jemal, 2017). Además del sexo, el envejecimiento es uno de los factores de riesgo más importantes debido a que la incidencia está muy relacionada con el aumento de la edad. En el 2016 aproximadamente el $99.3 \%$ y el $71.2 \%$ de todas las muertes asociadas con el CaMa se reportaron en mujeres de entre 40 y 60 años respectivamente, es por ello que surje la necesidad de realizarse el examen de mamografía a partir de los 40 años de edad o más (Ferlay et al., 2015). Otro factor importante es la historia familiar, casi una cuarta parte de todos los casos de CaMa están relacionados con ella, es decir, las mujeres cuya madre o hermana tienen o tuvieron CaMa, son más propensas a esta enfermedad.

Por otro lado, los factores reproductivos como la menarca temprana, la menopausia tardía, la edad avanzada al primer embarazo y la baja paridad pueden aumentar el riesgo de CaMa. Cada retraso de 1 año en la menopausia aumenta el riesgo de CaMa en un $3 \%$ y cada retraso de 1 año en la menarca o nacimiento adicional disminuye el riesgo en un 5\% a 10\%, respectivamente. (Horn, Åsvold, Opdahl, Tretli, \& Vatten, 2013). Otro factor importante asociado al riesgo de CaMa son los estrógenos endógenos y exógenos; el estrógeno endógeno generalmente es producido por el ovario en mujeres premenopáusicas, sin embargo se ha observado que la ovariectomía puede reducir el riesgo de CaMa (Key, 2013). Las principales fuentes de estrógenos exógenos son los anticonceptivos orales y la terapia de reemplazo hormonal, (Fahlén et al., 2013). 
Por otro lado, los estilos de vida modernos como el consumo excesivo de alcohol y la ingesta excesiva de grasas en la dieta, pueden aumentar el riesgo de CaMa; el consumo de alcohol puede elevar el nivel de hormonas relacionadas con los estrógenos en la sangre y desencadenar las vías del receptor de estrógeno (Jung et al., 2015). En cuanto a los hábitos alimenticios, la dieta occidental moderna contiene demasiada grasa y el exceso de su ingesta, especialmente la grasa saturada está asociada con la mortalidad y el mal pronóstico en pacientes con CaMa (Valentin, Da Silva, Privat, Alaoui-Jamali, \& Bignon, 2012). El riesgo de CaMa también es elevado en las mujeres que fuman y beben, sin embargo la relación entre el tabaquismo y el riesgo de CaMa sigue siendo controvertida debido a que se han detectado mutágenos del humo del cigarrillo en el líquido mamario de mujeres no lactantes. Hasta el momento, existen diversas evidencias que demuestran que fumar, especialmente a una edad temprana, tiene un mayor riesgo de pader CaMa (Figura 11) (Kispert \& McHowat, 2017).

\subsection{Métodos de prevención y diagnóstico de CaMa}

El diagnóstico del CaMa es uno de los mejores métodos para prevenir esta enfermedad; en algunos países desarrollados la tasa de supervivencia relativa de 5 años de los pacientes con CaMa es superior al $80 \%$ gracias a la prevención temprana (Rivera-Franco Monica M \& Leon-Rodriguez Eucario, 2017). En la última década se ha avanzado de manera importante en el desarrollo de métodos preventivos, los cuales juegan un papel fundamental en la disminución de los índices 
de mortalidad y en la mejora de la calidad de vida de los pacientes, quienes actualmente tienen más opciones para la prevención del CaMa (Majeed et al., 2014). El objetivo de la prevención es determinar el proceso de desarrollo de la enfermedad antes de que se desarrollen sus síntomas completos, lo que puede impedir o prevenir el desarrollo de un tumor maligno; los métodos de prevención actuales incluidos los exámenes de detección, quimioprevención y prevención biológica son más directos y efectivos que hace algunos años. El principal resultado de la prevención es la disminución de la mortalidad por cáncer gracias a la detección temprana, las pruebas de screening y de diagnóstico son el principal ejemplo para ésto (Teng et al., 2011). Éstas pruebas comprenden la mamografía, ultrasonografía, resonancia magnética, auto exploración mamaria, así como métodos de imagenes modernas y más precisas que ayudan a la detección temprana de tumores o lesiones que predisponen a los tumores (Figura 11).

\subsubsection{Métodos de Screening: Mamografia}

La detección temprana juega un papel importante en la prevención del CaMa, la mamografía es la única una herramienta de detección oportuna ampliamente utilizada en el diagnóstico de CaMa y en nuestro país se ha demostrado su eficacia en la reducción de la mortalidad y el aumento en las tasas de supervivencia (DeSantis et al., 2016). Los métodos de tamizaje para el diagnóstico de CaMa más utilizados son la mamografía y la autoexploración mamaria, desafortunadamente la falta de cultura de prevención hace que la mayoría de los tumores malignos de 
mama sean diagnosticados en etapa avanzada y las mamografías en su mayoría se han utilizado más con fines de diagnóstico que de detección (García et al; 2012).

Es un método que emplea el uso de rayos $\mathrm{X}$ de baja energía para obtener imágenes de alta resolución de la mama, el procedimiento se lleva a cabo en 20 minutos y no requiere ningún agente de contraste. El objetivo de la mamografía es detectar lesiones no palpables (menores de $0.5 \mathrm{~cm}$ ), calcificaciones, asimetrías en la densidad mamaria y/o distorsión de la arquitectura de la glándula. Los nódulos son objetos que aparecen en ambas proyecciones con densidad media y alta y sus contornos son indicadores de malignidad (van Dam et al; 1988).

Por otro lado, la autoexploración mamaria es una técnica de detección del CaMa basada en la observación y palpación de las mamas. En México existen diversas publicaciones con respecto a la enseñanza y prevalencia del empleo de la autoexploración mamaria (Ortega-Altamirano y López-Cervantes, 2000), los resultados sustentan la efectividad de esta técnica al reportar que las mujeres que la practican, fueron capaces de detectar lesiones de al menos $1 \mathrm{~cm}$ y cuando son superficiales de hasta $0.5 \mathrm{~cm}$. El impacto de la autoexploración mamaria a nivel mundial muestra datos poco prometedores y no refleja disminución de la mortalidad, sin embargo, en algunos países desarrollados, los reportes refieren un mejor pronóstico para las pacientes, ya que se detectan lesiones en etapas clínicas I y II (Millar, 1993). En nuestro país el $90 \%$ de los casos de CaMa son detectados gracias a que la propia paciente detecta un abultamiento o nódulo y en estos casos ya se 
trata de un estadio avanzado de la patología (López-Carrillo; et al 2001). Se ha encontrado que la exploración física de la mama permite una detección de hasta $50 \%$ de lesiones no vistas en mamografías, con un valor predictivo positivo de $73 \%$ y negativo de $87 \%$ (Levi et al; 2005).

\subsubsection{Resonancia Magnética (RM)}

Es otra herramienta de detección ampliamente utilizada para el CaMa, es más sensible que la mamografía y juega un papel importante en mujeres de alto riesgo, especialmente en la detección del carcinoma ductal invasivo (Greenwood et al., 2013). En comparación con la mamografía, la RM no se ve afectada por la densidad mamaria como en la mamografía sino que por el contrario tiene ventajas para detectar el CaMa primario, la metástasis ganglionar axilar, los tumores residuales después de la quimioterapia neoadyuvante u otros tumores pequeños (Morrow, Waters, \& Morris, 2011). Los avanzados escáneres de la RM pueden medir tejidos tan pequeños como $0.5 \mathrm{~mm}^{3}$ y su especificidad alcanza tasas de detección que van del $37 \%$ al 100. El ensayo de detección digital de imágenes mamográficas (DMIST), mostró que la mamografía digital tenía un mejor rendimiento diagnóstico que la mamografía de película en mujeres pre y postmenopáusicas con menos de 50 años de edad, lo que sugiere que la mamografía digital de alta resolución puede reemplazar a la mamografía convencional en el futuro. Ambas técnicas hasta el momento pueden utilizarse ampliamente en países de bajos y medianos ingresos, lo que ayudaría a seguir disminuyendo la mortalidad si las mujeres tuvieran una cultura 
de prevención al realizarse la prueba por lo menos cada dos años (Pisano et al., 2008).

\subsubsection{Mammaprint y Secuenciación del DNA}

Actualmente, para ayudar a tomar la mejor decisión sobre el tipo de terapia a la que responderán con más éxito los pacientes, existen las firmas multianalíticas tales como TAILORx, RxPONDER, MINDACT, Oncotype DX, MammaPrint, EndoPredict, Índice de cáncer de mama $(\mathrm{BCl})$ y Prosigna (PAM50). El objetivo de estas firmas multianalíticas es determinar con mayor precisión la expresión predominante del tipo de marcador molecular característico de cada fenotipo (luminal $A \circ$ B) o la direncia en el número de copias de sus genes.

Mammaprint es la primera prueba genómica que formará parte del cuadro básico del sector salud en México, con ella se puede determinar el riesgo de recurrencia de la enfermedad que tiene el paciente luego de la cirugía. El método de Mammaprint es aplicable a toda paciente en estadios de CaMa I y II, es decir, las etapas previas a una metástasis (Chavarri-Guerra et al., 2014). Consiste en calcular el nivel de actividad de aproximadamente 70 genes en una muestra del tumor maligno, con los que se determina la probabilidad de riesgo de recurrencia o metástasis a una proyección de 10 años después del diagnóstico, lo anterior con el objetivo de ayudar a tomar decisiones sobre los tratamientos basadas en el riesgo que exista de que el cáncer regrese (Sánchez-Forgacha, Carpinteyro-Espínb, Alemán-Ávilesc, \& Sánchez-Basurto, 2017). Lamentablemente a pesar de ser una tecnología de última 
generación se encuentra limitada por parámetros de inclusión tales como los fenotipos tumorales, pues sólo pueden ser candidatas las mujeres cuyos tumores sean luminales A o B y HER-2+; para los fenotipos TN no hay posibilidades de someterse a éste estudio (Peláez-García et al., 2017).

Otro método de última generación en la prevención y detección del CaMa es la secuenciación individual del DNA. Los estudios de secuenciación de ultima generación (NGS), han revelado que el CaMa luminal es una enfermedad extremadamente heterogénea.

Las mejoras en el empleo de ésta tecnología han logrado que éste sea un método efectivo en la disminución de la incidencia y la mortalidad del CaMa, sobre todo cuando es de tipo hereditario (Paluch-Shimon et al., 2016). La importancia en el empleo de la secuenciación del DNA radica su papel como método de prevención, debido a que es posible examinar la secuencia del DNA de células sanas para determinar si existe algún riesgo a futuro de padecer éste u otro tipo de cáncer. En segundo lugar, cuando es empleada como método de diagnóstico, es posible proporcionar al paciente el tratamiento más adecuado según las alteraciones genéticas del tumor (Sotiriou \& Pusztai, 2009). Preferentemente es recomendable en mujeres con antecedentes hereditarios de CaMa. En éste método especialmente se considera de interés las mutaciones en los genes BRCA1 y BRCA2, pues el riesgo de CaMa aumenta considerablemente si un individuo hereda mutaciones en estos genes (Anders \& Carey, 2009). Se sabe que aproximadamente del $20-25 \%$ de los 
cánceres de mama son hereditarios y que del $5-10 \%$ son causados por mutaciones en BRCA1 y BRCA2.

\subsubsection{Quimioprevención para CaMa TN}

En la ultima década se ha logrado un gran avance en la prevención del CaMa, sin embargo aún no hay un buen panorama en la mejora de terapias efectivas para el fenotipo TN. El fracaso en los tratamientos farmacológicos existentes para este fenotipo se debe principalmente a la ausencia de la expresión de los RE, RP y de HER-2, lo anterior hace del CaMa TN sea altamente agresivo y metastásico, con mayor riesgo de recaída y con una deficiente tasa de sobrevivencia a 5 años (Akshata Desai, 2013). En la última década, los grupos de investigación han trabajado sobre el desarrollo de diversos biomarcadores potenciales dirigidos contra el cáncer, tales como: EGFR, el receptor de andrógenos (RA), PARP y mTOR; asi como también sobre los biomarcadores basados en microARNs, tales como miR374b-5p y miR-629-3p (Mathe, Scott, \& Avery-Kiejda, 2015) (Massihnia et al., 2016). En un ensayo clínico de fase II, se logró demostrar que la combinación de Cetuximab y Cis-platino dirigida a inhibir el EGFR, aumentó la supervivencia libre de progresión de 1.5 a 3.7 meses y la supervivencia global de 9.4 a 12.9 meses (Baselga et al., 2013); por otro lado, en un estudio de fase II, el inhibidor de los RA: Bicalutamine, fue probado en un grupo de pacientes con CaMa TN, mostrando un beneficio clínico del 19\% en los pacientes. En otros ensayos de fase clínica I y II el Iniparib; un inhibidor de PARP fu probado en un grupo de pacientes mostrando resultados prometedores, 
sin embargo, el ensayo clínico de fase III fracasó al no observarse mejoría en la supervivencia libre de progresión ni en la supervivencia global (O'Shaughnessy et al., 2014).

Diversos grupos de trabajo elucidaban que las terapias dirigidas a la vía PI3K/AKT/mTOR podrían ser un éxito para éste fenotipo tumoral, se realizaron diversaos ensayos empleando el Everolimus, un inhibidor de la vía mTOR (blanco de la rapamicina) en combinación con doxorrubicina y bevacizumab, observando un aumento de la tasa de respuesta objetiva, pero no de la tasa de beneficio clínico. Pese a la diversidad de ensayos dirigidos a encontrar una eficaz terapia para el CaMa TN ninguno ha tenido éxito, se cree que una de las razones principales de esta falla podría ser la heterogeneidad de TNBC (Basho et al., 2017).

Sin duda se requiere de trabajo intenso para dilucidar sobre el descubrimiento de un biomarcador clave para el tratamiento del CaMa, sobre todo el TN; sin embargo, mientras esos sucede, es importante considerar que el CaMa es prevenible, puesto que la reducción de los factores de riesgo y la quimioprevención son dos medidas principales para prevenirlo. Solo el $4,1 \%$ de las mujeres de alto riesgo están dispuestas a tomar medicamentos para la quimioprevención. Es necesario desarrollar mejores medicamentos con menos efectos adversos y una relación riesgo-beneficio favorable en el futuro (Ropka, Keim, \& Philbrick, 2010).

La búsqueda de nuevos fármacos para tratamiento del cáncer involucra minimizar en tiempo los mecanismos para probar su eficacia; lo anterior se ve beneficiado con el 
uso de modelos in vivo, que puedan reproducir el diagnóstico de una enfermedad y que nos permitan experimentar nuevas drogas, o combinaciones de diferentes fármacos en un tiempo menor utilizando herramientas altamente sensibles y específicas (Robles-Castillo et al; 2011). Con el objetivo de atacar el metabolismo energético de la célula tumoral como blanco terapéutico, proponemos para este proyecto dos fármacos: la Metformina utilizada para tratar diabetes mellitus tipo 2 (DMT2) y el Ox, el cual es un inhibidor de la LDH, y su posible efecto coadyuvante, actuando sobre dos de las principales características de la célula tumoral: disminución del consumo de glucosa e inhibición de la proliferación y crecimiento celular a través de la vía mTOR.

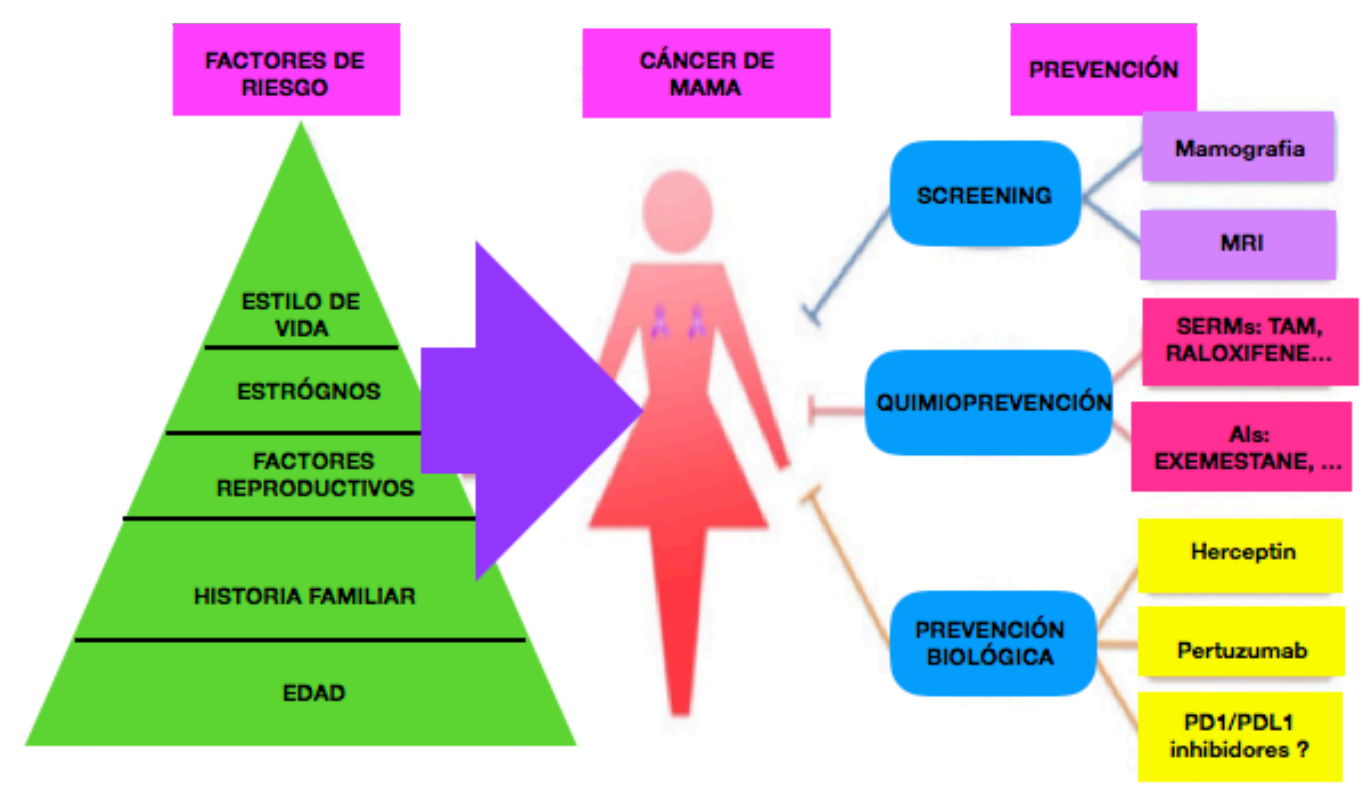

Figura 11. Factores de riesgo y prevención en cáncer de mama. Muestra los factores de riesgo y los posibles factores de prevención asociados al establecimiento del CaMa, los cuales posiblemente ayuden a la disminución de la incidencia y mortalidad de éste padeciemiento. Tomado y modificado de Kispert \& McHowat, 2017). 


\subsection{Mecanismos moleculares del cancer}

\subsubsection{Blanco de Rapamicina; mTOR}

En 1990 estudios en levaduras y mamíferos permitieron el descubrimiento de mTOR (mammalian Target of Rapamycin, por sus siglas en inglés), una proteína de $250 \mathrm{kDa}$ que funciona como blanco celular en mamíferos (Cidado y Park, 2012). mTOR es una serina treonina cinasa que a nivel basal y en condiciones de deprivación de nutrientes juega un papel fundamental en la integración de señales de crecimiento, proliferación, sobrevivencia y activación de autofagia (Perl, 2015). Ha surgido como un efector crítico en las vías de señalización celular y se ha identificado como regulador master de señales metabólicas. Su desregulación se encuentra mediada por diversos eventos mutacionales, lo que en algunos casos conlleva al desarrollo de tumores malignos o beningnos que se generan por la activación de oncogenes y la inactivación de genes supresores de tumores (Wullschleger, Loewith, \& Hall, 2006) y, hasta hace poco diversos estudios sugieren que mTOR también se encuentra desregulado por alteraciones en la expresión de miRNAs (MacFarlane \& R. Murphy, 2010). La via mTOR ha sido implicada en diversas enfermedades relacionadas con la edad: como el cáncer, la neurodegeneración y la diabetes, de hecho se ha observado que la inhibición genética o farmacológica en levaduras, moscas, gusanos y ratones extiende la esperanza de vida (Blagosklonny, 2010). mTOR estructural y funcionalmente nuclea 2 complejos multiprotéicos sensibles a rapamicina y a la disponibilidad de nutrientes, estos complejos son mejor conocidos como mTORC1 y 
mTORC2 (Hoogeveen-Westerveld et al., 2012), que de manera conjunta promueven la transcripción de genes implicados en el metabolismo de carbohidratos y la lipogénesis, mejoran la traducción de proteínas, la regulación del inicio de la transcripción, el metabolismo y la inhibición de la autofagia (Yang y Guan, 2007). El complejo mTORC1 se activa a través de la disponibilidad de nutrientes (aminoácidos), factores de crecimiento (insulina, IGF-1: factor de crecimiento insulínico-1) y del estado de energía celular (relación AMP/ATP). Estos estimulan mTORC1 a través del Complejo de Esclerosis Tuberosa 1 (TSC1-hamartin) y 2 (TSC2-tuberina) (TSC; por sus siglas en inglés) (Haar et al., 2007; Sancak et al., 2007). El complejo mTORC1 también se ha identificado como un mediador del efecto Warburg (glucólisis aerobia) que permite la supervivencia celular bajo condiciones de hipoxia (Blagosklonny \& Hall, 2009). El complejo TSC1 es acompañado de otros sustratos que río abajo median la promoción de diversos mecanismos, tales como la traducción del RNAm a través de la fosforilación de 4E-BP1 y de la cinasa p70S6, la supresión de la autofagia a través de Atg13 y de la cinasa ULK1, la biogénesis de ribosomas, importación de nutrientes, síntesis de lípidos y activación de la transcripción (Blagosklonny, 2010) (Kapahi et al., 2010).

Alteraciones en la vía mTOR median el estableciemiento de la tumorigénesis, las cuales contribuyen al crecimiento descontrolado de tumores. Diversos estudios sustentan que éste crecimiento celular es debido a la sobre estimulación de la síntesis de proteínas a través de S6K y 4E-BP1 (Düvel et al., 2010). Otra consecuencia de la señalización aberrante de mTOR es la síntesis de lípidos a través 
de la activación del factor de transcripción SREBP1; también estimula la vía de las pentosas fosfato para generar NADPH y ribosa, ambos procesos que juegan un papel importante crecimiento celular descontrolado (Schieke et al., 2006). Uno de los mecanismos más importantes que genera la la aberración de mTORC1 y que actualmente es el centro de estudio, es la expresión del gen glucolítico mejor conocido como HIF-1 $\alpha$, lo que contribuye a la generación de altas tasas glucóliticas y a su vez generar la sobre expresión de los transportadores de glucosa 1 y 2 (GLUT; por sus siglas en inglés), y de este modo dar lugar a la glucóliosis aerobia o efecto Warburg, característica de la mayoría de los tipos de cáncer. Lo que culmina con la regulación negativa de la autofagia, mecanismo célular de reciclaje catabólico de proteínas y orgánulos, que probablemente contribuye al mantenimeinto o inbibición del crecimiento tumoral (Düvel et al., 2010). Lo anterior resalta la importancia del complej mTORC1 como parte de la vía mTOR en la regulación del metabolismo y de la importancia de los cambios metabólicos en el cáncer (Colombi et al., 2011).

mTORC2 es el segundo complejo que por su asociación con los ribosomas es insensible a la disponibilidad de nutrientes y que a diferencia de mTORC1, no se une a la rapamicina y en consecuencia se le denomina "complejo insensible a la rapamicina". Se define particularmente por su papel en la biogénesis de ribosomas y por su interacción con Rictor ("rapamycin-insensitive companion of mTOR") (Grunt y Mariani, 2012). Dado que el contenido de ribosomas determina la capacidad de crecimiento de la célula, este mecanismo asegura que mTORC2 sólo esté activo en 
células en crecimiento. mTORC2 regula el citoesqueleto de actina, la supervivencia celular y otros procesos a través de la fosforilación de los miembros de la familia AGC cinasa, incluidos Akt, SGK1 y PKC. (Huang, Dibble, Matsuzaki, \& Manning, 2008). Se encuentra conformado por un complejo multiproteínico: Rictor, proteína 1 activada por la cinasa activada por estrés (mSIN1), Protor, GBL, Deptor y mLST8. Promueve la supervivencia celular mediante la activación de Akt y aunque su regulación es menos conocida, se sabe de su asociación dependiente con PI3K, (Laplante \& Sabatini, 2012) y de su participación en la proliferación celular a través de la fosforilación de IGF2. Similar a mTORC1, mTORC2 activa SREBP1 post y transcripcionalmente para mejorar la glucólisis y la lipogénesis. De manera importante, se sabe que la interacción entre mTORC2 y la insulina promueve la supervivencia celular a través de la reorganización del citoesqueleto (Dazert \& Hall, 2011).

La inactivación de mTOR es una de las vías que puede conducir a la modulación de la autofagia, asi como a la inhibición de la síntesis de los genes de las enzimas que participan en la glucólisis. Ambas vías metabólicas: glucólisis y mTOR, regulan la apoptosis y autofagia, mismas que se encuentras alteradas en diversos tipos de cáncer; sin duda éstas podrian llegar a ser en un futuro, blancos prometedores para el tratamiento no sólo de CaMa sino de la mayoría de los tipos de cáncer (Fang et al; 2011). Por otra parte los defectos en las vías de muerte celular son una característica típica del cáncer que pueden ser manipuladas para desarrollar nuevas alternativas terapéuticas, siendo la vía mTOR, un blanco prometedor por su función a nivel 
metabólico en la inhibición de la proliferación celular tumoral Figura 12 (Bartlett, 2010).

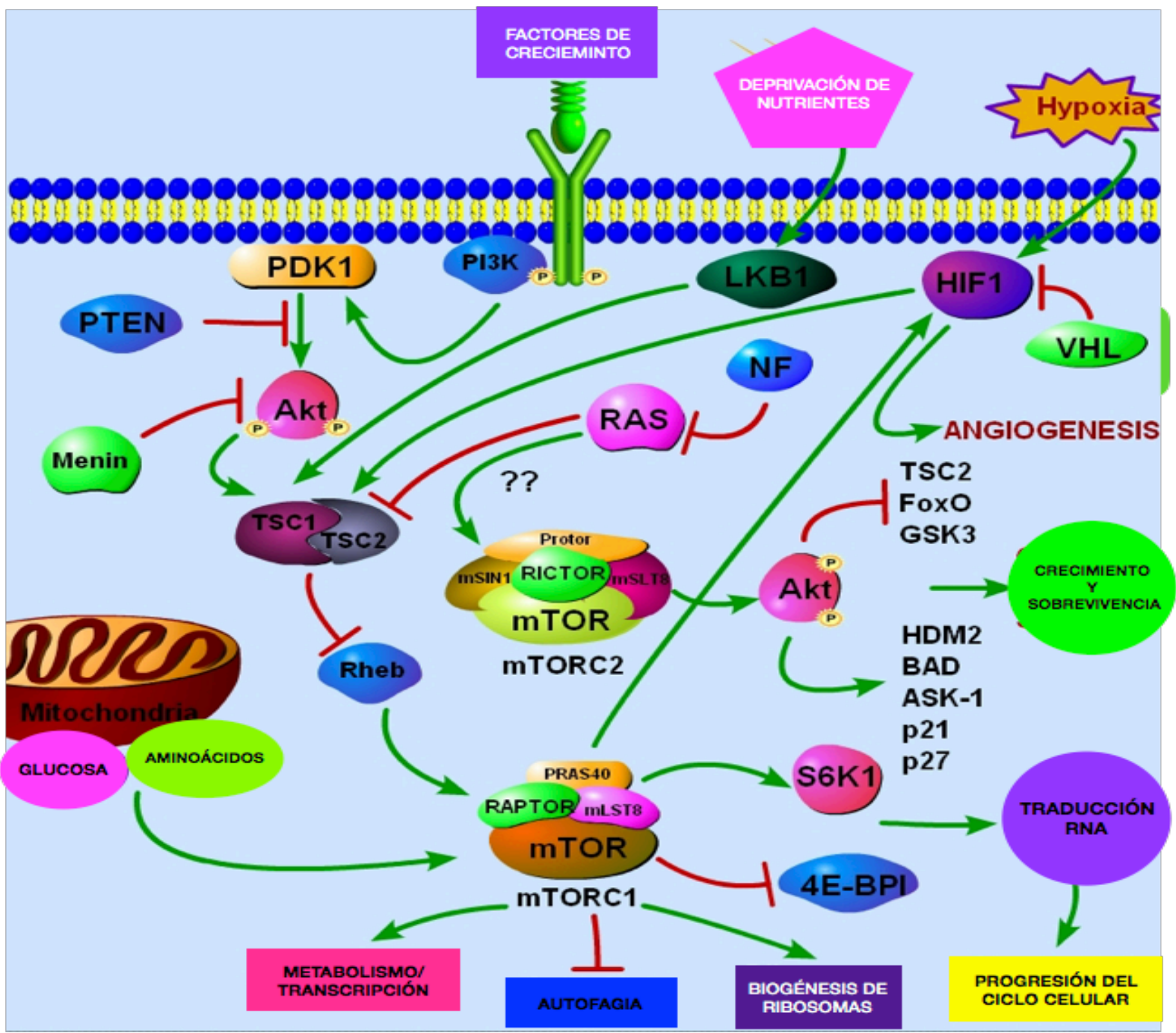

Figura 12. vía mTOR y sus implicaciones en el metabolismo de la célula tumoral. Muestra la vía mTOR y sus diversas implicaciones en el metabolismo de la célula en condiciones basales (biogénesis de ribosomas, autofagia, crecimiento y sobrevivencia; mientras que su desregulación implica inhibición de los procesos antes mencionados; de manera importante: progresión del ciclo celular, crecimiento, sobrevivencia e inhibición de autofagia. Tomado y modificado de Saran, Foti, \& Dufour, 2015). 


\subsubsection{Crosstalk entre Apoptosis y Autofagia}

La autofagia y la apoptosis son dos importantes procesos celulares que involucran una diversa red de proteínas complejas. Ambos procesos juegan un papel importante en la determinación del destino celular, el desarrollo, la homeostásis, los procesos fisiológicos y patológicos, por sólo mencionar algunos. Además de tener implicaciones importantes en el desarrollo del cáncer (Tabla 1) (Maiuri, Zalckvar, Kimchi, \& Kroemer, 2007) (Eisenberg-Lerner, Bialik, Simon, \& Kimchi, 2009). La conexión entre estos dos mecanismos de muerte celular es compleja, sin embargo, es crítica para el destino celular (Figura 13). Por ejemplo, bajo ciertas condiciones celulares la autofagia puede promover la supervivencia y evitar la apoptosis, en otras condiciones, la autofagia puede culminar en muerte celular ya sea dependiendo de la apoptosis o de forma independiente en caso de falla apoptótica. A pesar de los diversos estudios sobre éste paradigma, aún no está claro si la autofagia representa un mecanismo para prevenir la apoptosis o para activar la muerte celular programada no apoptótica (S. K. Bhutia et al., 2010). La autofagia y la apoptosis son vías esenciales que juegan un papel importante en la degradación celular, la compleja interacción que existe entre ellas es controlar el destino celular en condiciones tanto fisiológicas como patológicas (Liu \& Ryan, 2012). Aunque las vías moleculares que las conectan siguen sin entenderse, en lo que respecta a la etiología del cáncer existe un gran interés en el estudio de la conexión entre ellas (B. Levine \& Klionsky, 2004). Dentro de este contexto ampliamente se conoce que la apoptosis es un mecanismo que actúa como supresor de tumores, mientras que el papel de la muerte 
celular asociada autofagia es más complicado, ya que su función cambia a lo largo de la tumorigénesis pues se ha visto que es esencial en la iniciación y el desarrollo tumoral o bien de manera contraria puede actuar como un mecanismo supresor de tumores (Rosenfeldt \& Ryan, 2011).

\begin{tabular}{|c|c|c|}
\hline PROTEÍNA & PAPEL EN AUTOFACIA & PAPEL EN APOPTOSIS \\
\hline \multicolumn{3}{|c|}{ PROTEÍNAS AUTOFÁGICAS } \\
\hline mTOR & forma inactiva implicada en la iniciación & regula apoptosis \\
\hline Beclina-1 & nucleación del autofagosoma & induce apoptosis mitocondrial \\
\hline UNRAG & sobre-regula la interacción de Vps34-Beclina-1 & $\begin{array}{c}\text { antiapotótica, inhibe translocación de Bax del } \\
\text { citosol a la mitocondria }\end{array}$ \\
\hline AMBRA & sobre-regula la interacción de Vps34-Beclina-1 & $\begin{array}{l}\text { regula apoptosis mitocondral, escinde } \\
\text { caspasas y calpaina }\end{array}$ \\
\hline Atg3 & conjuga con Atg12 & regula muerte celular mitocondrial \\
\hline Atg5 & conjuga con Atg12, elongación autofagosoma & $\begin{array}{l}\text { interactúa con FADD para inhibir apoptosis, } \\
\text { escinde fragmentos- } \mathrm{N} \text { e induce apoptosis } \\
\text { mitocondral }\end{array}$ \\
\hline Atg12 & elongación de autofagosoma & $\begin{array}{l}\text { estimula apoptosis mitocondrial mediante la } \\
\text { inactivación de Bcl2 y Mcl1 }\end{array}$ \\
\hline Atg4D & procesa LC3 & induce apoptosis \\
\hline p62 & $\begin{array}{l}\text { unión con LC3, promueve degradación de } \\
\text { agregados de proteínas poliubiquitinadas }\end{array}$ & activación y procesamiento de Atg8 \\
\hline \multicolumn{3}{|l|}{ PROTEÍNAS APOPTÓTICAS } \\
\hline Bcl2, Bcl-xL & interactúa con Beclina-1 e inhibe autofagia & antiapoptóticas \\
\hline Bad, Bak, BNIP3, Nix & $\begin{array}{c}\text { proautofágicos, interrumpe interacción } \\
\text { Beclina-1/Bcl-2 }\end{array}$ & proapoptóticas \\
\hline Bax, PUMA & Proautofágica, tipo no canónico & proapoptóticas \\
\hline p53 & $\begin{array}{l}\text { in ibe p } 53 \text { citoplasmático } \\
\text { induce DRAM a través de p53 }\end{array}$ & proapoptótica \\
\hline Noxa & $\begin{array}{l}\text { induce autofagia interrumpiendo interacción } \\
\qquad \text { Mcl-1/Beclina-1 }\end{array}$ & proapoptótica \\
\hline Bim & secuestrá Beclina-1, inhibe autofagia & proapoptótica \\
\hline XIAP & inhibe señalización por Mdm2-p53 & inhibe caspasa 3 y 7 \\
\hline cFLIP & previene interacción entre ATG3 y LC3 & inhibe caspasa 8 \\
\hline
\end{tabular}

Tabla 1. Proteínas con doble papel en Apoptosis y Autofagia. sustenta la teoría que ambos procesos se llevan a cabo de manera conjunta. Tomada y modificada de Mukhopadhyay et al; 2014. 
Si esto último fuera real, se deduciria que la inducción de la autofagia podría ser un enfoque terapéutico útil para el tratamiento del cáncer en células resistentes a la apoptosis (B. Levine \& Kroemer, 2008). Dado que la autofagia y la apoptosis desempeñan múltiples funciones esenciales en la homeostasis celular, es probable que exista una extensa correlación entre ellas debido a la participación de las moléculas nodales que generan el crosstalk entre ambos mecanismos. Una de las interacciones nodales de suma importancia en el inicio de la conexión de éstos mecanismos, involucra la interacción de dos moduladores metabólicos clave: Beclina-1 y Bcl-2; río abajo también se involucra la escisión de Beclina-1 mediada por caspasas; la interacción UVRAG/BAX (Yin et al., 2011); la conjugación ATG12/ATG (Radoshevich et al., 2010); la interacción ATG12/Mcl-1; la interacción ATG5/FADD (Pyo et al., 2005) y la escisión de Calpaína dependiente de calcio mediada por ATG5 y p53 (Xia et al., 2010). Existen diversos estudios que sustentan que la inhibición de la autofagia o de la apoptosis jueguan un papel importante en la promoción del cáncer y que particularmente una falla en las proteínas antes mencionadas sean las protagonistas moleculares de mayor importancia en el establecimiento de la enfermedad. Un efector esencial en el proceso de autofagia es la Beclina-1 y a su vez también juega un papel importante en la conexión con la vía de la apoptosis. Beclina-1 humana es una proteína de 450 aminoácidos que contiene tres dominios de estructura conocidas como: dominio $\mathrm{BH} 3$, (residuos 108-127) y un dominio C-terminal conservado evolutivamente (residuos 248-450) (Kang, Zeh, Lotze, \& Tang, 2011). Beclina-1 es una proteína que interactúa con las proteínas anti-apoptóticas Bcl-2 y se asocia con PI3Kc3 y p150 para formar el complejo de 
nucleación vesicular esencial para la autofagia (Wirawan et al., 2010)(Sujit K. Bhutia et al., 2010). Es por ello que la interacción Beclina-1/Bcl-2 fue la primera conexión molecular establecida entre la autofagia y la apoptosis. A través de diversos estudios se ha ido estableciendo la relación de Beclina-1 y Bcl-2 en el desarrollo del cáncer; por ejemplo, se ha observado que al eliminar a Beclina-1 monoalelicamente se redujo en un $40 \%$ los cánceres de mama humanos. Con éste estudio se estableció el primer vínculo funcional entre la autofagia y el cáncer (Sujit K. Bhutia et al., 2010).

Las proteínas $\mathrm{Bcl}-2$ regulan principalmente la apoptosis en la membrana mitocondrial, donde secuestran a Bax, lo que impide la permeabilidad de la membrana mitocondrial y la liberación de citocromo-c. Asimismo Bcl-2 localizado en la Retículo Endoplásmico (RE) previene la autofagia regulada por la falta de nutrientes mediada por Beclina-1, uniéndose al factor 1 de autofagia (NAF1), que estabiliza la interacción entre Bcl-2/Beclina-1 en la superficie del RE. En células deficientes en NAF-1, la interacción entre Bcl-2 y Beclina-1 se interrumpe y el inicio de la autofagia se altera, lo que sugiere que los miembros de la familia $\mathrm{Bcl}-2$ inhiben la autofagia mediada por Beclina-1. Además, se ha demostrado que Bcl-2 mitocondrial inhibe indirectamente la autofagia al secuestrar la proteína activadora Ambra-1 de Beclina-1 (Cotter, 2009). En condiciones de estrés Bcl-2 debe ser desplazado de Beclina-1 y Bax para inducir la autofagia y la apoptosis, respectivamente. De hecho, cuando se induce la autofagia, el complejo Bcl2/Beclina-1 se ve alterado por las proteínas proapoptóticas only-BH3. Estas proteínas se unen a los sitios hidrofóbicos de $\mathrm{BH} 3$ con $\mathrm{Bcl}-2$ o $\mathrm{Bcl}-\mathrm{xL}$ e interrumpen 
la interacción entre Bcl-2/Bcl-xL y Beclina-1 para inducir la autofagia (Zhou, Yang, \& Xing, 2011). Curiosamente la interacción Bcl-2/Bcl-xL/Beclina-1 no afecta la función antiapoptótica de Bcl-2. Aunque el mecanismo aún no se conoce con exactitud, se cree que Bcl-2 tiene afinidad relativamente débil por Beclina-1 en comparación con su afinidad por las proteínas only-BH3 (Ashkenazi, 2008). Además de la regulación por proteínas only- $\mathrm{BH} 3$, la interacción de Beclina-1 y Bax con $\mathrm{Bcl}-2 / \mathrm{Bcl}-\mathrm{xL}$ puede regularse por modificación postraduccional para estimular tanto la autofagia como la apoptosis (Wei, Pattingre, Sinha, Bassik, \& Levine, 2008).

Las células que expresan Beclina-1 dentro del dominio BH3 presentan disminución de la unión de Bcl-xL/Beclina-1 y promueve una mejor formación de autofagosomas. Por el contrario, las células que expresan Beclin-1 no fosforilable exhiben aumento de la unión de Beclina-1 a Bcl-xL (White, 2015). Se ha demostrado que la sobreexpresión de Beclina-1 aumenta la apoptosis inducida por fármacos anticancerígenos en células de cuello uterino, sensibilizando así a las células a fármacos quimioterapéuticos (Sun et al., 2010).

También se ha demostrado que la inhibición de la expresión de Bcl-2 eleva los niveles de Beclina-1 y da como resultado la muerte de células de CaMa (Akar et al., 2008). Tambien se sabe que Bcl-2 puede regular la autofagia inducida por Beclina-1 así como la apoptosis intrínseca por unión directa a Beclina-1 y Bax/Bak, entonces cualquier fármaco que inhiba $\mathrm{Bcl}-2$ podría regular positivamente la autofagia y la apoptosis. Los inhibidores farmacológicos de $\mathrm{BH} 3$ tales como ABT-737, empleados 
por primera vez como inhibidores antiapoptóticos de Bcl-2, causaron la regresión de xenoinjertos en ratones (Chipuk, Moldoveanu, Llambi, Parsons, \& Green, 2010). De manera conjunta se observó que el inhibidor de Bcl-2: ABT-737, también afectó la interacción entre proteínas antiapoptóticas y Beclina-1, con lo que se demostró que éste compuesto inhibió competitivamente la unión de Beclina-1 con Bcl-xL y debilitó la unión de Beclina-1 con Bcl-2, liberando así Beclina-1 para estimular autofagia dependiente de Beclina-1 (Decuypere, Parys, \& Bultynck, 2012).

El papel de Beclina-1 en la interacción entre la apoptosis y la autofagia también puede ser regulado por las caspasas (Su, Mei, \& Sinha, 2013). Se ha observado que la apoptosis mediada por caspasas disminuye los niveles celulares de Beclina-1 y en consecuencia reduce los niveles de autofagia y aumenta los de apoptosis. Hasta la fecha, se han identificado tres sitios de escisión de caspasa en Beclina-1, tales como D133, D146 y D149 (Rohn et al., 2011). Los reguladores moleculares clave Beclina1/Bcl-2 parecen determinar el inicio de la respuesta celular, por lo tanto se cree que una nueva terapia farmacológica capaz de dirigirse a estos, probablemente pueda inducir la reprogramación metabólica de las células tumorales, lo que haría una terapia prometedora contra el cáncer (Kang et al., 2011).

Dentro del contexto metabólico, es bien conocido que las condicones bioenergéticas intracelulares (ATP/ADP) determinaran el tipo de muerte celular que ocurrirá (Cleland et al., 2011). En el caso de la apoptosis es bien sabido que es el proceso más costoso en términos de consumo de energía, ya que requiere la activación de 
caspasas y la formación de apoptosomas (Safe, 2015); mientras que la autofagia puede ayudar al proceso apoptótico, asegurando altos niveles de ATP para enfrentar y restaurar el estado metabólico de la célula que más allá de la sobrevivencia conduce a la muerte celular (Loos, Engelbrecht, Lockshin, Klionsky, \& Zakeri, 2013). Diversos estudios muestran que la autofagia excesiva desencadenada por terapias anticancerígenas pueden conducir a la muerte celular en diversos tipos de células de cáncer, lo que destaca un nuevo papel de la autofagia que actúa no solo como un guardián sino también como un ejecutor de la muerte celular (Cheng, Ren, Hait, \& Yang, 2013). Como ya se ha mencionado, la autofagia es un contribuyente crucial para el mantenimiento de la homeostasis celular, sin embargo, también es cierto que en ausencia de apoptosis, la vía autofagia es antitumoral mediante la promoción de la muerte celular no apoptótica. Lo anterior sugiere que la interconexión entre apoptosis y autofagia siga siendo un paradigma en la progresión del cáncer (Mizushima, Levine, Cuervo, \& Klionsky, 2008).

Actualmente sólo se puede elucidar que dependiendo de las circunstancias y como mecanismo de defensa, uno de ambos procesos de muerte celular se puede activar cuando uno de ellos es defectuoso (A. J. Levine \& Puzio-Kuter, 2010). Esto sugiere que la evasión de la muerte celular es una de las herramientas terapéuticas más importantes que ha tomado importancia en los ultimos años que puede ser útil no sólo para el tratamiento del CaMa sino también para otros tipos de cáncer. 


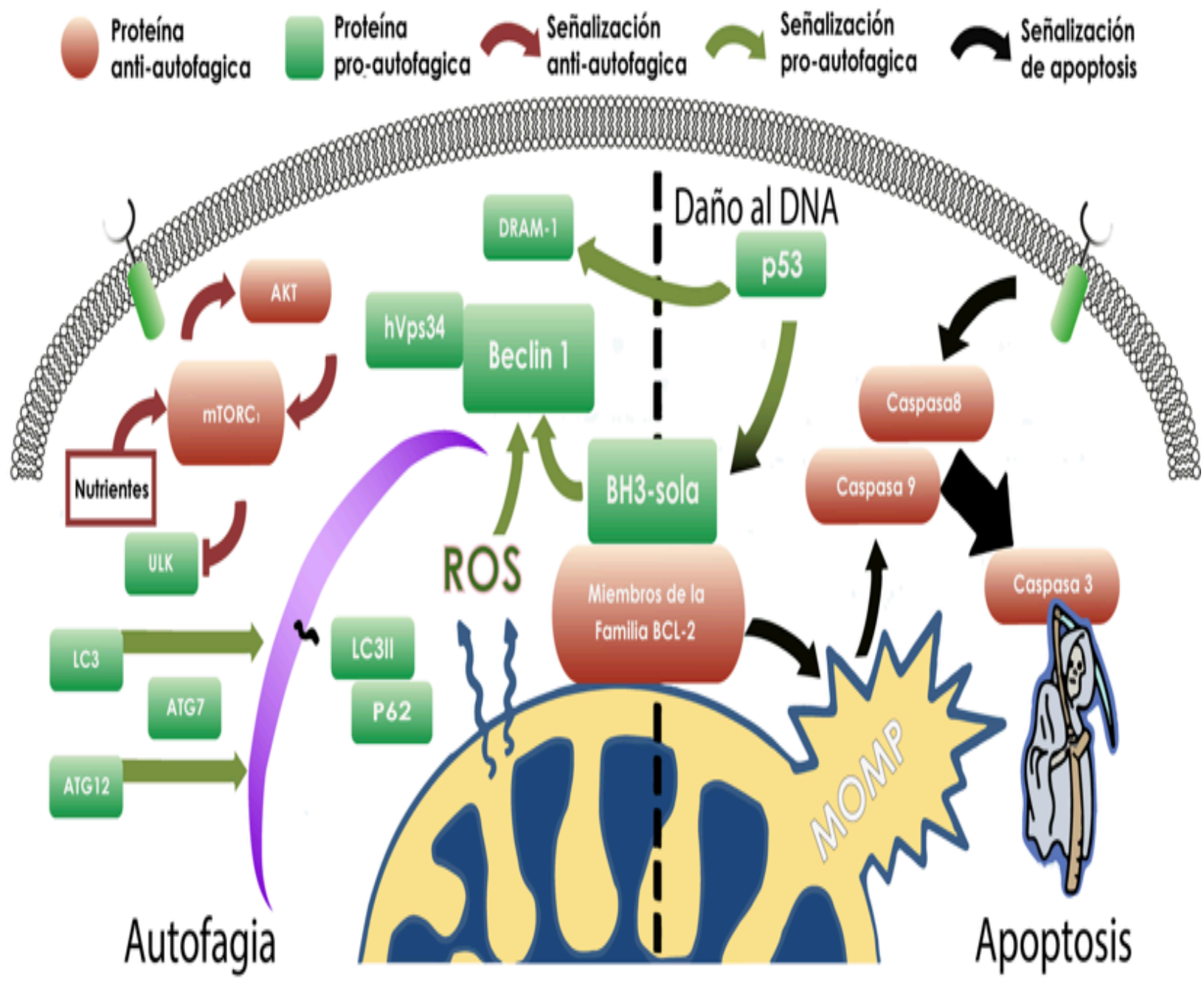

Figura 13. Interacción entre apoptosis y autofagia. Muestra la importante interacción entre apoptosis VS autofagia; diversos estudios sustentan que son mecanismos que se llevan a cabo de manera conjunta y dependiente. A la izquierda autofagia y a la derecha apoptosis, como puede observarse los miembros de la familia only-BH3, juegan un papel importante como intermediarios de ésta intecacción. Tomado y modificado de Mukhopadhyay, Panda, Sinha, Das, \& Bhutia, 2014.

Actualmente es controversial si la autofagia funciona como proceso de muerte celular o como mecanismo de sobrevivencia (Morselli et al., 2009); existen estudios en donde es necesaria la autofagia para promover el proceso de apoptosis (Suman et al., 2014); lo que sugiere que la autofagia puede funcionar como un proceso supresor 
de tumores. Hacen falta diversos estudios para elucidar si ambos mecanismos (autofagia y apoptosis) se lleven a cabo de manera independiente o si uno depende de otro (Glick et al., 2010).

\section{Metabolismo de la célula tumoral: Efecto Warburg}

Hasta hace algunos años el cáncer se concebia como una enfermedad genética en la cual diversas mutaciones se acumulaban durante varios años y éstas se heredaban progresivamente en cada ciclo celular a las subsecuentes poblaciones de células hijas, estas mutaciones se manifestaban hasta que se presentara un factor que desencadenará su mecanismo. Sin embargo, la conceptualización sobre el conocimiento de la biología celular y molecular de las células tumorales ha cambiado, pues hasta hace poco se ha retomado la observación hecha por Otto Warburg en 1924, donde se establece al cáncer como una enfermedad metabólica y no genética (Tennant, Durán, Boulahbel, \& Gottlieb, 2009). Warburg formuló la hipótesis de que las células tumorales principalmente generan energía mediante la descomposición no oxidativa de la glucosa, lo que hace que el crecimiento del cáncer sea factible (Gonzalez et al., 2014). Este fenómeno se conoce como "efecto Warburg" y se basa en la disfunción mitocondrial, que se caracteriza por la insuficiencia respiratoria, lo que resulta en un cambio a la glucólisis aerobia. Basado en la hipótesis anterior, Warburg observó que a diferencia de las células normales, las células cancerígenas para cubrir sus necesidades energéticas utilizaban la vía de la glucólisis aerobia en presencia de condiciones fisiológicas de oxigeno en mayor 
demanda que la fosforilación oxidativa mitocondrial (OXFOS, por sus siglas en inglés). La OXFOS es una reacción mitocondrial y un proceso metabólico eficiente que genera mayor cantidad de ATP (ATP; adenosin-trifosfato) que la glucólisis y es empleado preferentemente por las células normales para sus requerimientos energéticos (Figura 14) (Díaz-Ruiz et al., 2011; Mathupala et al., 2010; Vander Heiden et al., 2009). Por otro lado la utilización de la glucólisis aerobia en condiciones de oxigeno empleada por células cancerígenas es un proceso de fermentación y es menos eficiente para la generación de ATP, también genera nicotinamida adenina dinucleótido en su forma reducida (NADH) y da como resultado la acumulación de piruvato y lactato. Sostener tan altas tasas proliferativas, proporciona a la célula tumoral la ventaja de resistir a las señales de muerte celular (Vander et al; 2009) e incrementar su masa celular y duplicar su DNA (Hanahan y Weinberg, 2011).

En ambos procesos se requiere sintetizar lípidos, proteínas y ácidos nucleicos, así como energía en forma de ATP. De esta manera la alta demanda energética y metabólica es resuelta en parte por un incremento en la absorción tanto de glucosa como de aminoácidos, principalmente glutamina (Svensson \& Shaw, 2012). El metabolismo de la célula tumoral depende de la glucólisis aerobia en distintas vías biosintéticas; por ejemplo, la glucólisis genera intermediarios necesarios para la síntesis de ribosa-5-fosfato y glicina, empleados en la biosíntesis de nucleótidos; además de glicerol, fundamental en el proceso biosintético de lípidos (Brown et al; 2013). 

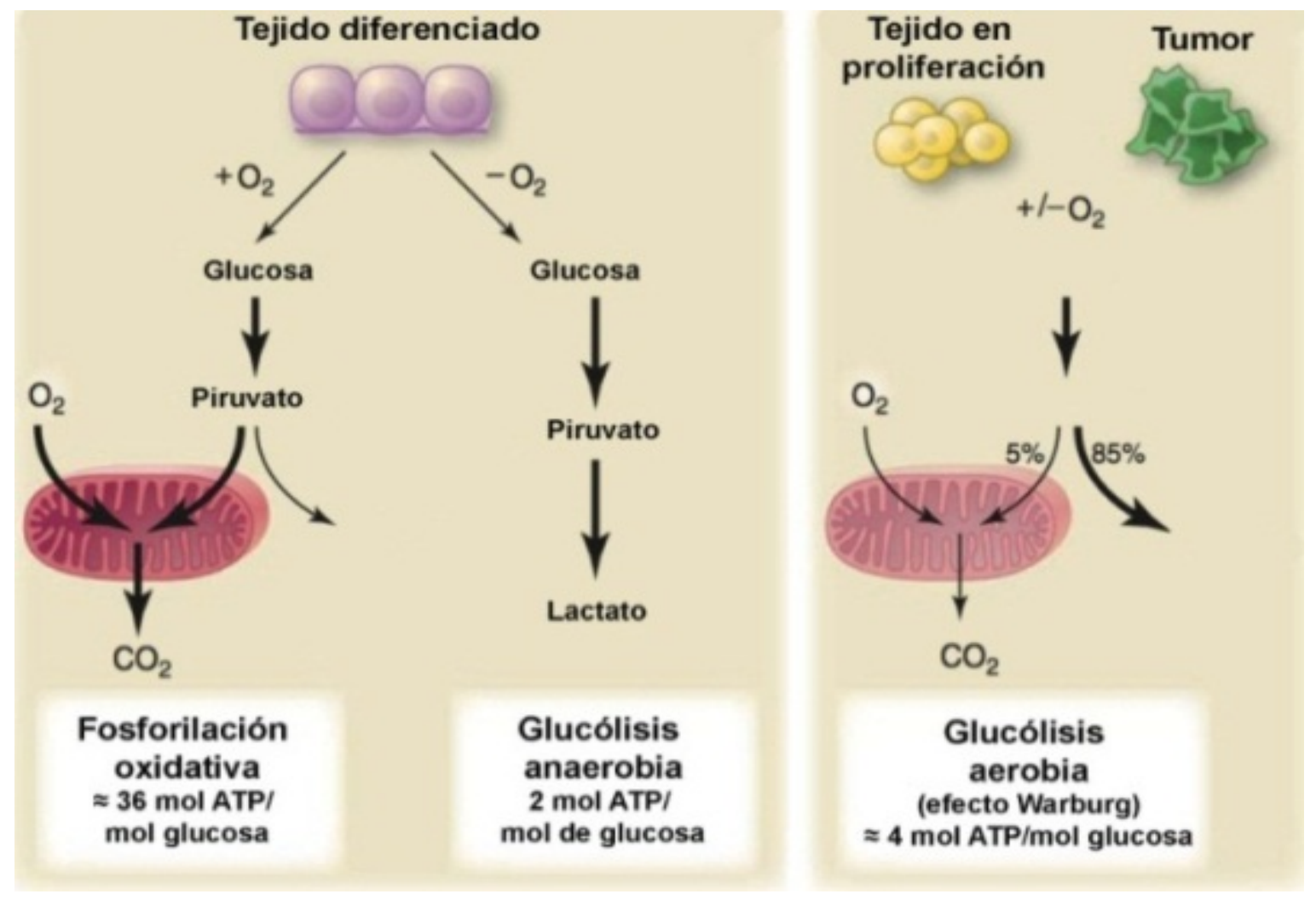

Figura 14. Glucólisis aerobia o efecto Warburg. Muestra el proceso de glucólisis aerobia o efecto Warburg. A la izquierda la glucólisis en condiciones basales es un mecanismo de obtención de energía utilizado por células normales, la glucosa es oxidada a piruvato mediante 10 reacciones catalizadas por sus enzimas correspondientes, con el objetivo de obtener energía en forma de ATP. A la derecha, la mayoría de las células tumorales toman la vía anaeróbica de conversión de piruvato en lactato, oxidando la glucosa en presencia de 02 , lo que se le denomina efecto Warburg. Tomado y modificado de Vander et al; 2009.

La glucólisis aerobia es esencialmente una reacción anaeróbica y el hecho de que las células cancerosas la utilicen en presencia de oxígeno les proporciona una ventaja de supervivencia. Esto se debe a que el microambiente tumoral se caracteriza por áreas de hipoxia (bajo nivel de oxígeno) (Kim et al., 2009), que finalmente compromete OXFOS y por lo tanto en cáncer. El microambiente hipóxico puede conducir a una mejor glucólisis en lugar de defectos en OXPHOS mitocondriales. Además, la disminución de la OXFOS conduce a la reducción de ROS que puede proteger a las células cancerosas de los efectos citotóxicos del daño 
oxidativo (Denko, 2008). La propensión de las células tumorales a depender de la glucólisis sobre la OXFOS sirve como un mecanismo potencial para eludir la apoptosis y por lo tanto promover la tumorogénesis. Es decir en el efecto Warburg el piruvato no es oxidado hasta $\mathrm{CO}_{2}$ y agua con la subsecuente producción de ATP, sino que la mayor parte de la glucosa es degradada preferiblemnte a lactato (Vander Heiden et al., 2009). Por lo tanto se ha sugerido que una de las funciones de éste efecto es mantener altos los niveles de los intermediarios requeridos en el ciclo proliferativo de la célula maligna (Lunt \& Vander Heiden, 2011).

El efecto Warburg está ampliamente documentado en tumores y líneas celulares mostrando la sobreexpresión de genes involucrados en el metabolismo de la glucosa, como por ejemplo glucoproteínas integrales de membrana (GLUTs), involucradas en el transporte de glucosa (Noguchi et al, 2008; Chen et al, 2008; Chen et al; 2010), y de diversas enzimas involucradas en la glucólisis tales como la glucosa fosfato isomerasa ( $\mathrm{PGI}$, por sus siglas en inglés), la aldolasa $\mathrm{A}$, la gliceraldehido-3-fosfato deshidrogenasa (GAPDH, por sus siglas en inglés), entre otras. Una de las enzimas clave en el efecto Warburg es la isoforma A de la lactato deshidrogenasa $(\mathrm{LDH}-\mathrm{A})$, enzima tetramérica con dos subunidades $(A \circ B)$ que se clasifica en cinco isoformas (A4, A3B1, A2B2, A1B3 y B4) que catalizan con diferente eficiencia la conversión de lactato a piruvato y viceversa (Altenberg y Greulich, 2004). La LDHA también llamada M-LDH o LDHA4, tiene mayor afinidad por el piruvato el cual es reducido a lactato, que una vez sintetizado, es liberado al espacio extracelular alcanzando los niveles tan altos como 10-20 mM (Yang Yang et al., 
2014). El lactato es un metabolito importante y ha sido relacionado con distintos procesos del desarrollo tumoral. Por ejemplo, se ha estudiado la relación entre el incremento en la producción de lactato con la motilidad e invasividad celular por medio de la activación de metalo-proteasas (Lee et al; 2010). Así mismo el lactato también es capaz de inhibir la activación, diferenciación y expresión de antígenos en células dendríticas y se ha asociado la presencia de niveles altos de lactato como un marcador de metástasis en diferentes neoplasias (Brizel et al, 2001; Walenta et al; 2000).

El efecto Warburg es uno de los fundamentos conceptuales para entender el metabolismo de las células tumorales, en donde la OXFOS es favorecida por el incremento en la actividad metabólica de la LDH-A, misma que catalizar la conversión de piruvato a lactato también oxida a la NADH a nicotinamida adenina dinucleótido en su forma oxidada $\left(\mathrm{NAD}^{+}\right)$, disminuyendo de esta manera la actividad del ciclo de los ácidos tricarboxilicos (TCA) y por ende la OXFOS (Brand, 1985) y (Xie et al., 2014).

El desacoplamiento de la cadena respiratoria debido a la alta frecuencia de mutaciones observada en tumores, forzaría el metabolismo tumoral al incremento en la glucólisis, en donde solo sería necesaria una ligera disfunción de la cadena respiratoria para que el rendimiento de los 36 ATP por molécula de glucosa decayera (Gupta \& Bamezai, 2010). Esto explicaría el alto consumo de glucosa y la producción de ATP por medio de glucólisis. Este conocimiento ha sido empleado exitosamente 
para desarrollar herramientas clínicas útiles en la detección de masas tumorales in vivo, como la tomografía emisora de positrones (PET, por sus siglas en inglés, positron emisor tomography) empleando $\left[{ }^{18} \mathrm{~F}\right]$ fluoro-desoxiglucosa $\left({ }^{18} \mathrm{FDG}\right)$ el cual es un radionúclido análogo de la glucosa (FDG-PET) (Hawkins y Phelps 1998; Gambhir, 2002).

El efecto Warburg se ha convertido en un blaco prometedor para el tratamiento de diversos tipos de cáncer. En cuanto a las terapias blanco de éste efecto, se sabe que existen diversos hallazgos que apoyan el uso de Oxamato (Ox) como un inhibidor competitivo de LDH-A y de la aspartato aminotransferasa (AAT), lo que conlleva a la inhibición de la glucólisis y del crecimiento celular in vitro e in vivo en células de cáncer cervical (HeLa), mama y astrocitoma (Thornburg et al., 2008).

Actualmente el "efecto Warburg" o el aumento de la glucólisis aeróbica en diversos tumores sustenta que el metabolismo aberrante de la célula tumoral es un marcador predictivo del establecimiento de la enfermedad, lo cual se podría aprovechar en un futuro para optimizar las pruebas de detección del cáncer y el tratamiento del cáncer (Ganapathy, Thangaraju, \& Prasad, 2009)(Gatenby \& Gillies, 2008). 


\subsection{Terapias farmacológicas inhibididoras del metabolismo de la célula tumoral}

Existen diversas enzimas críticas involucradas en la glucólisis aeróbia que son consideradas como blancos terapéuticos efectivos para el tratamiento del cáncer y se han diseñando fármacos que inhiben su actividad. Por ejemplo: Ritonavir, Fasentin, Genistein, STF31 y WZB117, son fármacos anticancérigenos diseñados para inhibir la acción de GLUT1 y ejercer efectos antitumorales al disminuir la captación de glucosa en las células tumorales, lo que lleva a la muerte celular a través de la privación de nutrientes (Lane, Fan, \& Higashi, 2009). Para la inhibición de HK2 se han empledo diversas drogas como la 2-desoxi-D-glucosa (2-DG, por sus siglas en inglés), el 3- Bromopiruvato (3-BP, por sus siglas en inglés) y la lonidamina (Froissart et al., 2011). Los resultados de los ensayos clínicos han demostrado que en combinación con doxorubicina, la lonidamina tiene una mejor eficacia terapéutica para el tratamiento de tumores de mama, próstata, melanoma, cerebro y ovario. Lamentablemente durante el proceso de tratamiento se observó alta toxicidad hepática relacionada con el empleo de ésta combinación (Nath et al., 2015). En cuanto al empleo de la 2-DG, algunos estudios han demostrado que su uso en combinación con el inhibidor de PI3K o mTOR (PF-04691502), logró inducir que la glucólisis aeróbia se dirija hacia la OXFOS en células de linfoma en tiempos cortos y con recurrencia de efecto proliferativo, sin embargo se demostró que ésta 
combinación puede causar una fuerte citotoxicidad hacia en las células normales (Mediani et al., 2016).

Se observó que 3PO logró reducir rápidamente la captación de glucosa, la secreción de lactato y el ATP intracelular mediante la inhibición de PFK-2 en células T-Jurkat de leucemia (Telang et al., 2012), y con PFK15, un derivado del 3PO, se observó que tiene actividad antitumoral al reducir la captación de la 18-FDG y el contenido de F26BP en tumores xenoinjertados. Además, este agente exhibe actividad proapoptótica en células transformadas tanto in vitro como en tumores in vivo (Clem et al., 2013). Para la inhibición de PKM2 ise han desarrollado terapias farmacológicas como TT-232, VK3, VK5 y el Compuesto 3; con éste último se ha observado que puede causar inhibición del elemento de respuesta a glucosa del gen de la piruvato quinasa hepática (PK-L, por sus siglas en inglés) y los inhibidores VK3 y VK5 inhiben selectivamente la PKM2 para reducir la glucólisis en células cancerosas (Tekedereli et al., 2012).

De manera importante se pensaba que la sola inhibición de mTOR funcionaba como un blanco terapéutico efectivo, sin embargo el papel de la rapamicina, un fármaco inmunosupresor aprobado por la FDA y sus análogos sirolimus, temsirolimus y everolimus como inhibidores alostéricos de mTORC1 se limitan a la actividad de éste complejo con minimo efecto sobre la la actividad de mTORC2 (Facchinetti et al., 2008). En estudios preclínicos, se informó que la rapamicina y sus análogos tienen actividad antiproliferativa en varios tipos de cáncer y ahora están siendo probados en 
la clínica para el tratamiento del linfoma y el cáncer neuroendocrino, endometrial y de mama; sin embargo existen diversos estudios clínicos e in vitro, que han demostrado que el efecto de éstos inhibidors sólo relentiza la glucólisis a través de la señalización de Akt/mTORC1 pero no la inhiben por completo, lo que deja en duda su efectividad al observar la recurrencia de la enfermedad asi como la proliferación en células de mama y próstata respectivamente (G.-Q. Chen et al., 2015). En los últimos años se ha centrado la atención en el desarrollo de estrategias terapéuticas que tengan como objetivo revertir el efecto Warburg a través de la inhibición de la glucólisis y la inducción de la OXFOS. Para ello existen diversos fármacos aprobados por la FDA que se dirigen al metabolismo de de la célula tumoral, los cuales incluyen: $\mathrm{N}$-acetilcisteína (NAC), metformina, hidroxicloroquina y rapalogos (Albert et al., 2010). Se ha observado que el empleo de NAC funciona como un antioxidante para prevenir estrés oxidativo y puede bloquear la autofagia en el estroma del tumor, interrumpiendo así el "combustible" suministrado a las mitocondrias celulares (Mediani et al., 2016).

Otro fármaco bien estudiado como antidiabético y sus recientes implicaciones en el tratamiento del cáncer es la metformina, su mecanismo de acción se basa en la activación directa de AMPK y reduciendo la actividad del complejo I mitocondrial, lo que sugiere que puede prevenir el cáncer al inhibir los OXFOS mitocondrial (Tabla 2) (Bensinger \& Christofk, 2012). 


\begin{tabular}{|c|c|}
\hline FARMACO & MECANISMO DE ACCION \\
\hline Ritonavir, Fasentin, STF-31; WZB117 & inhibidor de GLUT1 \\
\hline 2-DG, 3-BP, LODINAMINA & inhibidor de HK \\
3PO,PFK15 & inhibidor de PFKFB3 \\
\hline OA, TT-232, VK3, VK5 & inhibidor de PK2M \\
\hline Rapamicina & inhibidor mTORC1 \\
\hline DCA & inhibidor de PDK1 \\
\hline NAC & antioxidante, previene estrés oxidativo \\
\hline Hidroxi-cloroquina & inhibidor de autofagia \\
\hline Metformina & inhibidor de OXFOS \\
\hline Halofuginona & inhibidor de Akt/mTORC1 \\
\hline
\end{tabular}

Tabla 2. Fármacos anticancerígenos con blanco terapéutico en el efecto Warburg. Muestra diversos fármacos anticancerígenos aprobados por la FDA, cuyo blanco terapéutico es la inhibición del efecto Warburg. Tomada y modificada de Chen et al; 2016.

Existe un gran número de fármacos inhibidores del metabolismo de la célula tumoral en estudios en fase clínica y otros encaminados en ensayos in vitro. Con base en el contexto anterior, recientemente nuestro grupo de trabajo se centró en la importancia del empleo de una terapia combinatoria conformada por Doxorubicina, Metformina y Oxamato de sodio (DoxMetOx) con bajos efectos citotóxicos y que de manera 
específica tengan como objetivo la inhibición de la glucólisis en combinación con un fármaco inhibidor que debilite la síntesis de los ácidos nucleicos.

\subsubsection{Doxorrubicina}

Doxorrubicina (Dox) es un fármaco antineoplásico de amplio espectro, comercialmente conocido como Adriamicina. Fue la primera antraciclina (ANT) de clae I, aislada de Streptomyces peucetius en 1960; es un agente quimioterapéutico de primera línea comúnmente empleado para el tratamiento de CaMa y de otros tipos de cáncer (Tacar, Sriamornsak, \& Dass, 2013). Su mecanismo de acción se basa en la inhibición de la topoisomerasa I y II, intercalandose en la doble hélice del DNA para interferir con su desencadenamiento y con ello finalmente inducir la muerte celular. Al unirse a múltiples dianas moleculares, como las enzimas I y II de la topoisomerasa, se producen una serie de efectos citotóxicos, lo que da como resultado daño en el ADN y la formación de complejos escindibles del mismo (Ignatiadis et al., 2012); la intercalación inhibe la acción de las polimerasas y la replicación del ADN asi como la transcripción del RNA, mecanismo que conlleva a la inhibición del crecimiento celular en las fases G1 y G2 (Lal, Mahajan, Chen, \& Chowbay, 2010). Debido a su inespecidicidad y alta citotoxicidad conlleva a padecer numerosos y severos efectos adversos en los pacientes que la reciben (EscuderoOrtíz et al; 2011). 
Su relación con la inducción de apoptosis es relativamente reciente (Eom et al., 2005). Dox se une a la subunidad 20 S del proteosoma para formar un complejo Doxproteasoma y de éste modo translocarse al núcleo a través de los poros nucleares (Kiyomiya, Matsuo, \& Kurebe, 2001). Con lo anterior Dox tiene una mayor afinidad por el ADN lo que le permite disociarse del proteasoma y asi unirse al ADN nuclear. Un estudio reciente destacó la capacidad del fármaco para intercalar no solo con ADN nuclear, sino también en el ADN mitocondrial (Ashley \& Poulton, 2009). Además Dox puede afectar la membrana celular directamente uniéndose a las proteínas del plasma, esto puede ocasiona la formación de radicales libres de hidroxilo altamente reactivos, responsables de los efectos secundarios provocados por el uso de la droga (Cardoso et al., 2008).

Otro mecanismo importante que se promueve debido al empleo de Dox es la activación de la AMPK cinasa conocida por mediar efectos apoptóticos y actua como sensor energético intracelular en condiciones de estrés (Okoshi et al., 2008). Existen diversos estudios realizados en una amplia gama de líneas celulares sobre Dox y su relación con AMPK, los cuales revelan que Dox induce la activación de AMPK en respuesta a la acumulación de especies reactivas de oxígeno (ROS) en células de miocardio H9c2 de rata (M.-B. Chen et al., 2011), lo anterior sustenta que Dox ocasiona la acumulación de ROS y de manera conjunta activa LKB1 y por consiguiente río arriba desencadena la señal necesaria para la activación de AMPK, lo que finalmente conduce a la fosforilación de p53 en la Ser15 y promover apoptosis. De manera importante, éste mismo patrón molecular se produjo en la linea 
celular productora de insulina MIN6. Lo anterior también sustenta que la activación de AMPK promueve la activación de las cinasas c-Jun (JNK), otro mecanismo de acción de Dox para inducir apoptosis (Høyer-Hansen et al., 2007).

\subsubsection{Metformina}

La metformina (Met) (1,1-dimetilbiguanida) es una biguanidina aislada del compuesto de la planta Galega officinalis (Chong y Chabner, 2009). Se sabe que éste glucófago que reduce elevados niveles de glucosa en sangre en pacientes con diabetes mellitus Tipo 2 (DMT2), su administración es vía oral y en altas dosis en humanos es inocua y teratogénica en diversas especies estudiadas (Graham et al; 2011). Actualmente es el fármaco de primera línea para el tratamiento de la DMT2 que por su capacidad hipoglucemiante inhibe la gluconeogénesis hepática a través de la activación de la proteína cinasa AMPK activada por AMP y desencadena la captación de glucosa en el músculo esquelético, lo que conlleva a la disminución de los niveles de glucosa e insulina en la sangre (Maida, Lamont, Cao, \& Drucker, 2011). Diversos estudios clínicos sugieren que la metformina a diferencia de otras biguanidas es relativamente segura y eficaz en el tratamiento de la DMT2, la cual se asocia con alto riesgo de cáncer lo que afecta la sobrevivencia del paciente; éste aumento de riesgo se ha atribuido al efecto promotor del crecimiento de los niveles elevados de insulina en plasma (Jalving et al., 2010). La resistencia a la insulina y la hiperinsulinemia resultante podrían promover la carcinogénesis directamente a través del receptor de insulina o indirectamente al aumentar los niveles del Factor de Crecimiento parecido a la Insulina-1 (IGF-1, por sus siglas en ingles), hormonas sexuales esteroideas, 
procesos inflamatorios y alteración de la homeostasis de las adipocinas (Alberobello et al., 2010). El potencial terapéutico de la metformina, esta asociado a la nefropatía diabética, las enfermedades cardiovasculares, enfermedad del ovario poliquístico y la prevención y/o el tratamiento de diversos tipos de cáncer, entre ellos el de mama, colon, próstata, riñón y páncreas (Lamanna, Monami, Marchionni, \& Mannucci, 2011). De manera importantente se conoce que reduce directa e indirectamente la proliferación de las células cancerosas a través de la disminución de los niveles de insulina y glucosa en sangre. En el contexto del riesgo de CaMa, se ha demostrado que la metformina disminuye las hormonas circulantes, como andrógenos y estrógenos, en donde los niveles elevados están relacionados con el desarrollo de cáncer de mama postmenopáusico (Bodmer, Meier, Krahenbuhl, Jick, \& Meier, 2010). Por lo tanto, el tratamiento con metformina puede servir como un factor que contribuya a la disminución del riesgo de cáncer, ya que diversos estudios epidemiológicos han demostrado que la exposición con metformina puede reducir la incidencia de cáncer y mejorar el pronóstico de éstos pacientes (Inzucchi et al., 2012); de manera importante se conoce que no solo puede ejercer propiedades anticancerígenas en tumores malignos establecidos, sino que también tiene efectos en prevenir el inicio del tumor (Sui et al., 2015)

El mecanismo de acción más aceptado de la metformina es mediante la activación indirecta de la proteína cinasa activada por adenosina monofosfato (AMPK), que actúa como sensor energético y que también desempeña un papel clave en la señalización de insulina (Faubert, Vincent, Poffenberger, \& Jones, 2015) . Se ha 
demostrado que la activación de AMPK inhibe la vía mTOR y de manera especifica, también inhibe la proliferación celular patológica de diferentes líneas celulares cancerosas. Alternativamente se describió que antes de la activación de AMPK los mecanismos mitocondrailes dependientes e independientes se han descrito como los precursores de la activación de AMPK (Kalender et al., 2010). Recientemente, debido a las implicaciones de la mitocondria en el cáncer, la metformina se ha descrito como un "veneno mitocondrial", la cual actúa a través de la inhibición del complejo 1 de la cadena respiratoria que conduce a la activación de AMPK y a la reducción de la síntesis de glucosa, lo que hace pensar según diversos estudios que la metformina es una terapia dirigida al metabolismo mitocondrial (Xu, Ji, \& Yan, 2012).

Diversos estudios epidemiológicos han demostrado que la exposición a metformina puede reducir la incidencia de cáncer y mejorar el pronóstico de éstos pacientes. Del mismo modo también se ha demostrado que la metformina no solo puede ejercer propiedades anticancerígenas en tumores malignos establecidos, sino que también tiene efectos en prevenir el inicio del tumor (Sui et al., 2015). Otro posible mecanismo se basa en la inhibición de la angiogénesis neoplásica y del crecimiento tumoral (Hatoum \& Mcgowan, 2015). Consistentemente con la disminución de la glucosa, se ha demostrado que metformina también disminuye significativamente los niveles de VEGF (factor de crecimiento endotelial vascular) y PAI-1 (Ersoy et al., 2008). Aunque estos resultados sugieren un papel fundamental de la señalización del complejo LKB1/AMPK, su acción antiangiogénica también podría ser independiente de la activación de AMPK (Dallaglio et al., 2014). Además de la inhibición de la 
proliferación en diversas líenas de cancer, la metformina también promueve la muerte celular mediante la activación de las vías apoptóticas a través de mecanismos dependientes e independientes de caspasas (Maiese, 2015). En lo que respecta a la vía idependiente, se refiere a la activación de PARP-1 (poli-ADP-ribosapolimerasa), y la translocación nuclear de AIF (factor inductor de apoptosis), que desempeña un papel importante en la muerte celular por apoptosis (Zhuang \& Miskimins, 2011). Además, se ha demostrado que en células de cáncer de colon, metformina indujo la estimulación de la autofagia y disminución de la glucólisis, probablemente un efecto estimulado por la deprivación de nutrientes. Y recientemente se ha demostrado que la combinación de metformina y 2desoxiglucosa inhibe la respiración mitocondrial y la glucólisis de una manera dependiente de p53 en células de cáncer de próstata, lo que lleva a una depleción masiva de ATP que afecta la viabilidad celular e induce apoptosis (Soga, 2013).

Aunque la mayoría de las investigaciones de laboratorio se han centrado en la vía de señalización mitocondrial-AMPK, diversas investigaciones han elucidado nuevos mecanismos de acción de la metformina. A pesar de que su mecasnimo aún no está claro, el consenso es que sus blancos terapéuticos más importantes son la reducción del nivel de glucosa en sangre y su acción como sensibilizador de la insulina, que sin duda es beneficioso para los pacientes con diabetes pero potencialmente importante en la reducción del riesgo de la mayoría de los cánceres, incluido el cáncer de mama. 


\subsubsection{Oxamato de sodio}

El Oxamato de sodio (Ox) es conocido como un potente inhibidor de la LDH-A, una enzima reversible que regula el flujo glucolítico, que convierte el piruvato (producto final de la glucolisis) en lactato mediante la oxidación de $\mathrm{NADH}$ a NAD ${ }^{+}$(Draoui y Feron, 2011). Se empleaba en humanos como agente atiparasitario, pero su uso se descontinuó con el advenimiento de fármacos más eficaces (Fiume, 1959). De manera específica Ox es un inhibidor competitivo de la actividad de la LDH-A por tener una alta homología con el piruvato (Simpson, 2012). Actúa como un enlace entre la glucólisis y el efecto Warburg y es bien sabido que la gran mayoría de tumores malignos muestran altos niveles de LDH-A en comparación con los tejidos normales (Jiayin An; et al. 2017).

Existen 5 isoenzimas de LDH activas en el tejido humano, cada una de las cuales se encuentra metabólicamente compuesta por dos subunidades $\mathrm{M}$ y $\mathrm{H}$ (comúnmente concidas como A y B) codificadas por LDH-A y LDH-B, respectivamente. La subunidad $\mathrm{M}$ es predominante en el músculo esquelético; mientras que la subunidad $\mathrm{H}$ es predominante en el músculo cardíaco. Un estudio inmunohistoquímico (IHC) reveló que tejidos normales y carcinomatosos tienen niveles similares de LDH-B mientras que LDH-A se expresó principalmente en células cancerosas, esto permite que la LDH-A sea empleada como un biomarcador pronóstico para diversas enfermedades malignas, entre ellas el cáncer (Le et al., 2010). La acción de la LDHA radica en sintetizar el piruvato citoplásmico en lactato, un paso importante en la producción de energía para las células cancerosas (Yu et al., 2017). La célula 
tumoral satisface su demanda de energía en gran parte mediante la glucólisis aerobia, proceso que puede ser inhibido mediante el bloqueo de la LDH-A. Esta enzima constituye el principal punto de control del "switch metabólico" de generación de energía de la glucólisis el cual es catalizado por la reducción de piruvato a lactato (Lee et al; 2010).

Diversos estudios sustentan que Ox puede ser una herramienta molecular clave en el bloqueo del metabolismo y crecimiento de las células tumorales, además de que es un fármaco no toxico que puede administrarse en animales de laboratorio hasta en 3g/kg (Papacostantinou y Colowick, 1961). Estudios realizados en una línea celular de CaMa MDA-MB-231 evidenciaron que el Ox produce un efecto anti-metabólico, inhibiendo específicamente la producción de intermediarios del TCA, del flujo glocolítico y de la actividad de la cadena de transporte de electrones (OXFOS) (Hamilton et al; 1995). En otros trabajos se demuestra que selectivamente suprime la proliferación celular en xenotransplantes inducidos con la línea celular MDA-MB-231 en ratones atímicos (Migneco et al, 2010). Estudios in vitro con la línea celular de hepatoma PLCPRF/5, se observó que el Ox produce un efecto antiproliferativo mediante la inhibición de la LDH-A y la disminución de los niveles de ATP (Liu et al; 2001). Así mismo se ha demostrado que Ox inhibe el consumo de la glucosa, el flujo glicolítico y el crecimiento celular en células HeLa (Ward et al, 2012). Este fármaco ha sido empleado con éxito en diferentes estudios in vitro en el analisis de la inhibición de la proliferación asi como también en la disminución de la LDH-A en 
líneas celulares MCF7 y MDA-MB-231. Estos resultados evidenciaron el efecto antiproliferativo de Ox (Zhao et al; 2009).

Recientemente, con el objetivo de reducir la acidosis láctica que ocasiona la fenformina se demostró que en combinación con Ox, se inhibe la conversión de piruvato en lactato en el citosol y por lo tanto previene la acidosis láctica. Curiosamente, la acidosis láctica es un fenómeno común en el microambiente del cáncer y está relacionada con la proliferación y la metástasis de las células cancerosas (Held-Warmkessel \& Dell, 2014). También se ha mostrado que la reducción de la LDH-A previno el crecimiento de la célula tumoral, por lo tanto la adición de Ox puede no solo mejorar el efecto secundario de la fenformina, sino que también podría inhibir el crecimiento y la metástasis. Además, la adición de Ox no solo reduce la producción de ácido láctico sino que también aumenta el efecto anticancerígeno de la fenformina, lo que sugiere la actividad sinérgica de Ox en la inhibición simultánea del complejo I de la cadena respiratoria y LDH-A por fenformina y Ox respectivamente (Miskimins et al., 2014). Recientemente Jiayin et al; 2017 investigó que al suprimir la actividad de la LDH-A con la exposición de Ox a diferentes concentraciones en céluas de adenoma pituitarios (GH3), se inhibió significativamente la captación de glucosa, la producción de lactato, la expresión de GLUT1 y la disminución de la expresión de la proteína reguladora de la invasión (MMP2, por sus siglas en inglés). Este mismo grupo de trabajo demostró en la misma línea celualar $(\mathrm{GH} 3)$ que la sobreexpresión de la LDH-A induce la progresión del ciclo celular; sin embargo la exposición a Ox inhibó la prolieración celular a través del 
bloqueo del ciclo celular en la fase G1/G0. Por tanto Ox además de arrestar la progresión del ciclo célular en ésta fase, adicionalmente también suprime la fosforilación de Akt y GSK-3ß. Esto sugiere que Ox probablemente regula de manera negativa la expresión de la ciclina D1 mediante la supresión de la activación de Akt y la activación de GSK-3 $\beta$ (Yang Yang et al., 2014).

De manera importante se ha revelado que el bloqueo de LDH-A con el empleo de Ox, inhibe de manera específica la glucólisis aerobia en las células tumorales, mientras que la mayoría de las células normales no se ven afectadas con el empleo de Ox. Lo que hace a la LDH-A un objetivo terapéutico altamente atractivo y el uso de Ox una herramienta impprtante para el tratamiento del cáncer (Quennet et al., 2006). A la fecha no existe un amplio estudio sobre las implicaciones de Ox como agente terapéutico en el tratamiento del cáncer, sin embrago los estudios hasta ahora indican que Ox juega un papel importante en la privación del sumisntro de energía de la célula tumoral, incidiendo de manera importante sobre el efecto Warburg en las células tumorales, lo que lo hace ser un blanco terapéutico prometedor para diversos tipos de cáncer, entre ellos el CaMa. Dado que su estructura química es similar al piruvato, es probable que su uso en pacientes sea inocuo (Miao, Sheng, Sun, Liu, \& Huang, 2013). Se sabe que una vez que la LDH-A es inhibida, los niveles de ATP disminuyen y la producción de especies reactivas de oxígeno mitocondrial (ROS) aumentan, acelerando la muerte de las células tumorales a través de la apoptosis (An et al., 2017). Por lo tanto es racional asumir 
que la inhibición de LDH-A bloquea la glucólisis y potencialmente provoca cambios deletéreos en el metabolismo tumoral.

\subsubsection{Combinación farmacológica: Doxorrubicina-Metformina-Oxamato de sodio}

Con la evidencia anterior, podríamos sugerir la hipótesis de que las terapias farmacológicas son un blanco importante sobre la depleción de las vías de generación de energía de las células tumorales y son la mejor estrategia para la probable inhibición del crecimiento tumoral mediante la inhibición del efecto Warburg y la síntesis de los ácidos nucleicos; promoviendo la activación de dos importantes mecanismos: muerte celular por apoptosis y/o autofagia.

En el 2010 nuestro grupo de trabajo empleó la combinación farmacológica de Doxorrubicina-Metformina-Oxamato de sodio (DoxMetOx) en un estudio in vivo, observando la disminución en el crecimiento de la masa tumoral del grupo de animales tratados con la misma. Lo que nos llevó a expecular que este efecto probablemente a la inducción de procesos de muerte celular por apoptosis y/o autofagia.

Hasta ahora no exiten estudios que sustenten la efectividad de los mecanismos de acción de la combinación de Doxorrubicina, Metformina y Oxamato de sodio en el tratamiento de diversos tipos de cáncer; estudios in vitro e in vivo sustentan que su 
empleo como terapia adyuvante o en duplets continua sin ser una estrategia efectiva en modelos de CaMa TN y de colon. Sin embargo en el 2013, en nuestro grupo de trabajo se evaluó la reprogramación metabólica de tumores sólidos en ratones atímicos de la cepa Fox ${ }^{\text {nu/nu }}$ empleando la triple combinación farmacológica: MetOxDox, inhibidores de importante vías energéticas de la célula tumoral (mTOR, glucólisis y síntesis de acidos nucléicos, respectivamente) como una estrategia eficaz para el tratamiento del CaMa TN. En el modelo in vivo se observó a través de micro Tomografía Emisora de Positrones (microPET; por sus siglas en inglés), que el grupo de animales tratado con DoxMetOx inhibió por completo y de manera importante el crecimiento de la masa tumoral a los 15 días de tratamiento i.p, sin observar severos efectos secundarios ni recurrencia de la enfermedad a los 3 meses post-tratamiento (Figura 15). Con este estudio se demostró que el bloqueo de las vía energéticas de la célula tumoral mediante el empleo de la combinación de DoxMetOx, resultó ser eficiente y altamente especifica, con mínimos efectos secundarios (García-Castillo et al., 2017). En este trabajo nuevamente empleamos la combinación farmacológica de DoxMetOx para evaluar a nivel molecular mediante ensayos in vitro la posible activación de la apoptosis a través de la evaluación de caspasa-3 y PARP, la inhibición de la fosforilación de mTOR (mTOR-p), la LDH-A y la activación de LC3-II, un marcador molecular crucial en el proceso de autofagia. En conjunto, estos resultados ayudarían a sustentar la hipótesis de que la inhibición simultánea de mTOR y LDH-A conduce a las células tumorales a activar la apoptosis y la autofagia y probablemente se proporcionaria un pronóstico prometedor a los pacientes 
diagnosticados con CaMaTN, fenotipo con menores expectativas de supervivencia que otros fenotipos de CaMa y también de otros tipos de cáncer.

Journal of Cancer 2016, Vol. 7

A
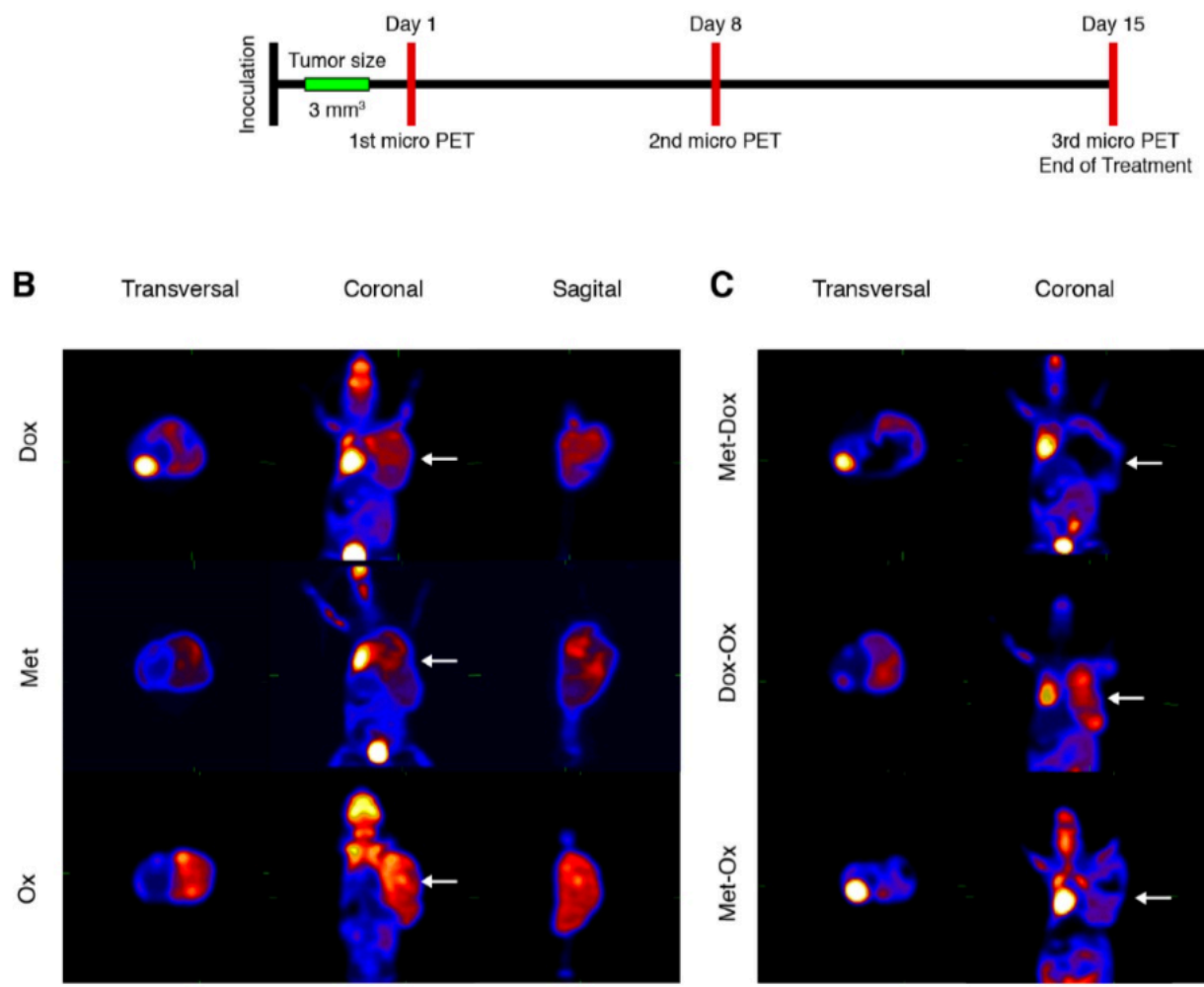

C Transversal Coronal Sagital
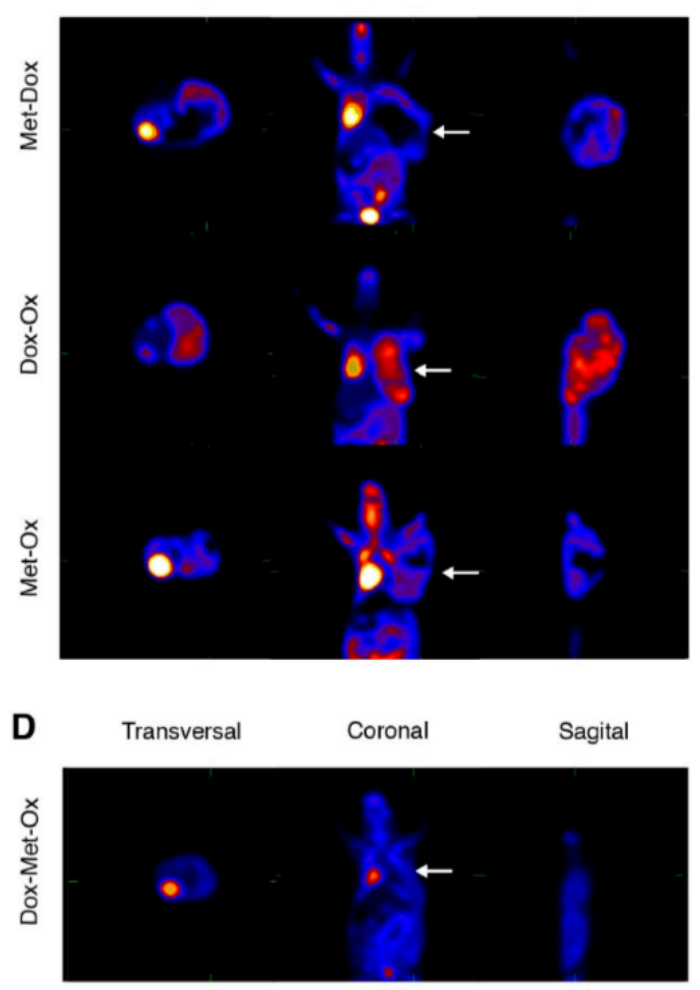

Figura 15. Microtomografia Emisora de Posotrones microPET: D) Muestra la efectividad de la triple terapia farmacológica (DoxMetOx) en el grupo de animales tratado con ella a los 15 días de su tratamiento (A). B y C) Grupos tratados con terapias adyuvantes y duplets; no se muestra efectividad en la disminución del crecimiento tumoral en ninguno de los grupos experimentales. Tomado de García-Castillo et al; 2017. 


\section{Justificación}

El CaMa en nuestro país es un problema de salud pública, en los últimos veinte años su incidencia y mortalidad ha ido en aumentado en los países en desarrollo, especialmente en mujeres jóvenes. En nuestro país, en el 2008 se registraron 13,939 nuevos casos y 4,500 muertes por CaMa en 2008 (Jemal et al; 2010). La Fundación Mexicana de Salud reportó que a partir del 2006 el riesgo de morir por este padecimiento excedió el riesgo de morir por cáncer cérvico-uterino, posicionando al CaMa como la principal causa de muerte por enfermedades oncológicas en México (Figura 5) (Knaul et al; 2009). Lamentablemente para nuestro país, se pronostica que para el 2030 cerca de 24,386 mujeres serán diagnosticadas con CaMa y 9,767 (40\%) morirán; siendo un reto importante para los Servicios de Salud (Chávarri-Guerra et al., 2012). El subgrupo TN de CaMa es el de peor pronóstico con bajas probabilidades de sobrevivencia y periodos cortos libres de la enfermedad. Debido a que es un fenotipo altamente hereogéneo no existe un tratamiento especifico y las estrategias farmacologicas existentes son poco exitosas y con severos efectos secundarios. Por lo que es importante establecer nuevas alternativas farmacológicas enfocadas en el bloqueo de una caracteristica distintiva y universal de la célula tumoral, es decir, incidir sobre su metabolismo más que sobre su genetica. Es por ello que con base en los resultados de los ensayos in vitro e in vivo descritos anteriormente, en este proyecto nos proponemos evaluar a nivel molecular el efecto de la terapia MetOxDox expuesta a cultivos primarios de xenotransplantes inducidos en un modelo in vivo de CaMa TN; con el objetivo de para evaluar si su posible 
reprogramación metabólica es debido a la activación de importantes procesos de muerte celular: apoptosis y/o autofagia.

\section{Planteamiento del Problema}

Los defectos en las vías de muerte celular son una característica típica del cáncer, aunque la resistencia a la apoptosis está estrechamente vinculada a la tumorigénesis, las células tumorales pueden inducir la muerte celular a través de mecanismos no-apoptóticos, tales como necrosis, senescencia y autofagia. Estos mecanismos de muerte celular son un blanco terapéutico prometedor, por ello es importante considerar que pueden ser manipulados a través del empleo de nuevas estratégias farmacológicas anti-cancerígenas que depleten el metabolismo del tumor a través de la inhibición de mTOR y la glucólisis, vías reguladoras de mecanismos de muerte por apoptosis y autofagia. Se requieren estudios a nivel molecular que sustenten la especificidad y sobre todo la inocuidad de MetOxDox en el fenotipo de CaMa TN.

\section{Hipótesis}

El empleo de la terapia concomitante DoxMetOx inhibe de manera específica la glucólisis aerobia y la fosforilación de mTOR en células tumorales de mama TN, induciendo muerte celular por apoptosis y/o autofagia. 


\section{OBJETIVOS}

\subsection{Objetivo General}

Evaluar a nivel molecular el tipo de muerte inducida por los inhibidores de la fosforilación de mTOR y la glucólisis aerobia: DoxMetOx, en un modelo de células tumorales de cáncer de mama triple negativo.

\subsection{Objetivos Particulares:}

1. Evaluar a nivel de proteína marcadores moleculares de apoptosis y autofagia inducidos por la triple terapia en la línea celular de CaMa TN.

2. Evaluar a nivel de mRNA la expresión de la LDH-A inducida por la triple terapia en la línea celular de CaMa TN.

3. Validar a nivel de ultra estructura la inducción de autofagia inducida por la triple terapia en la línea celular de CaMa TN.

4. Validar a nivel de ultra estructura la inducción de autofagia a traves de la expresión de la proteina LC3-GFP inducida por la triple terapia en la linea celular de CaMa TN. 


\section{MATERIAL Y MÉTODOS}

\subsection{Cultivo celular}

Se obtuvieron cultivos primarios de CaMa a partir de los xenotransplantes generados del modelo murino con la línea celualr MDA-MB-231. Despúes de haber sido extraidos, una parte fue almacenada a $-72^{\circ} \mathrm{C}$ y otra parte fue disgregada en placas Petri de 100x20 mm con medio DMEM/F12 (Gibco® life technologies) de la marca Gibco y una carga de 100 ul de anfotericina de IN VITRO para la obtención de los cultivos primarios. A este cultivo se le realizaban cambios de medio cada 3 dias y de manera conjunta se iban eliminando los residuos de tejido para evitar posibles contaminaciones. Al observar adhesión y crecimiento celular las placas fueron lavadas vigorosamente con PBS $1 \mathrm{X}$ frío y cosechadas con tripsina al $0.25 \%$ (TRIPSINA-EDTA de IN VITRO); las células fueron resembradas en nuevas cajas. Todos los cultivos se mantuvieron en condiciones de esterilidad en una incubadora a $37^{\circ} \mathrm{C}$ y con $5 \%$ de $\mathrm{CO}_{2}$ y $100 \%$ de humedad relativa y con medio DMEM/F12 de (Gibco $®$ life technologies) suplementado con Suero Fetal Bovino (SFB) (Biowest) al 10\% y con 10X de antibiótico/antimicótico de IN VITRO . Para todos los ensayos, se emplearon cultivos celulares a una confluencia del $80 \%$. 


\subsubsection{Concetracion empleadas de DoxMetOx para los ensayos}

La concentración a la cual fueron empleadas las terapias en estos ensayos, fueron determinadas en estudios previos en líneas celulares de CaMa TN (Garcia-Castillo; 2013). La IC50 de los fármacos se determinó mediante el método colorimétrico de Sulforrodamina-B (SFR-B) establecido por (Vichai \& Kirtikara, 2006). En lo que respecta a Dox se determinó una IC50 de 0.5 uM, Met con $25 \mathrm{mM}$ y Ox con $15 \mathrm{mM}$. Estas mismas concentraciones se han mantenido para el desarrollo de las estrategias experimentales de éste trabajo.

\subsubsection{Extracción de Proteínas}

Después de que los cultivos fueron tratados con los fármacos y tiempos de incubación correspondientes, se llevó a cabo la extracción de proteínas; para lo cual se utilizaron cultivos celulares al $\sim 80 \%$ de confluencia. La extracción de proteínas totales se llevó a cabo utilizando buffer de lisis RIPA (Thermo Scientific, Cat. 89901) adicionado con un coktel de inhibidor de proteasas COMPLETE (ROCHE Cat. 11836 153 001). Se retiró el medio a los cultivos y se lavó con $1 \mathrm{ml}$ de PBS 10x frío, posteriormente a las placas petri de $100 \times 15 \mathrm{~mm}$ se agregaron $80 \mu \mathrm{l}$ de buffer de lisis RIPA. Las células fueron colectadas con un scrapper y colectadas en un tubo de 2.0 $\mathrm{ml}$. La suspención celular fue lisada en hielo con un politrón durante 30 segundos y finalmente centrifugada a $12500 \mathrm{rpm}$ durante 30 minutos para separar los residuos celulares insolubles. La cantidad de proteínas obtenidas fue cuantificada con base en 
la técnica colorimétrica de Bradford (Towbin, H. et. al. 1979), empleando Bio-Rad Protein Assay (Kit \#5000002), las proteínas fueron cuantificadas a 595nm en un espectrofotómetro de placas Epoch (Biotek).

\subsubsection{Western Blot}

Con el objetivo de detectar la expresión a través de la técnica de inmunodetección de las proteínas de interés para apoptosis, autofagia y glucólisis, se emplearon los anticuerpos de caspasa-3 (sc-7148), PARP-1 (sc-8007), mTOR total (2983, Cell Signalling) y p-mTOR (fosforilado); (2971, Cell Signaling), LC3-B (2775s, Cell Signalling) y LDH-A (sc-27230). La separación de 50 mg de proteínas se llevó a cabo empleando la técnica de electroforesis SDS-PAGE (sodium dodecyl sulfate polyacrylamide gel electrophoresis) con el equipo Mini-PROTEAN Tetra System (BioRad) a 80 volts durante 2 horas aproximadamente. Posteriormente, las proteínas fueron transferidas a una membrana PDVF (polifluoruro de vinilideno) con un poro de $0.45 \mu \mathrm{m}$ (THERMO SCIENTIFIC \#88518) mediante transferencia semi-seca en un equipo Trans-blot Turbo (BioRad) a 20 volts por 30 minutos. Al terminar la transferencia, la membrana de PDVF fue bloqueada con una solución de leche libre de grasa al $5 \%$ en TBS-Tween $0.1 \%$ por 2 horas. Posteriormente se realizaron 3 lavados con TBS-Tween y se incubaron overnight (alrededor de 16 horas) con el anticuerpo primario de interés: (caspasa-3; 1:3000), (PARP-1; 1:3000), (mTOR; $1: 3000)$ y (p-MTOR; 1:3000), (LC3-B; 1:2000) y (LDH-A; 1:2000) y como control interno de carga se empleo $\beta$-actina (sc-47778; $1: 5000)$; todo a $4^{\circ} \mathrm{C}$ y con agitación 
constante (Tabla 3). Una vez transcurrido el tiempo de incubación del Ab primario, se realizaron tres lavados de 10 minutos cada uno con TBS-Tween y se incubó nuevamente con el Ab secundario correspondiente (anti-mouse IgG HRP; \#7076 y anti rabbit \#7074 de Cell Signalling empleados a una dilución de 1:5000 respectivamente) durante 2 horas a $4^{\circ} \mathrm{C}$ y agitación constante. Después de 2 lavados con TBS-Tween y uno con TBS 1x durante 10 minutos respectivamente, se llevó a cabo el revelado de las membranas, empleando el sustrato quimioluminiscente SuperSignal West Femto Maximun Sensitivity Substrate (Thermo Scientific Cat. 34095) y para la detección de las proteínas se utilizó el digitalizador C-Digit Blot Scanner de (Li-COR).

\begin{tabular}{|c|c|c|}
\hline ANTICUERPO PRIMARIO & No REFERENCIA & DILUCIÓN \\
\hline caspasa-3 & sc-7148 & $1: 3000$ \\
\hline PARP-1 & sc-8007 & $1: 3000$ \\
\hline LCS-B (Cell Signalling) & $2775 \mathrm{~s}$ & $1: 2000$ \\
\hline mTOR (Cell Signalling) & 2983 & $1: 3000$ \\
\hline p-mTOR (Cell Signalling) & 2971 & $1: 3000$ \\
\hline Beta Actina (Santa Cruz) & sc-47778 & $1: 5000$ \\
\hline Anti-mouse IgG-HRP (Cell Signalling) & 7076 & $1: 5000$ \\
\hline Anti-rabbit lgG-HRP (Cell Signalling) & 7074 & $1: 5000$ \\
\hline
\end{tabular}

Tabla 3. Relación de anticuerpos primarios y secundarios en la detección de Apoptosis y Autofagia y glucólisis en cultivos primaries de CaMa. 


\subsubsection{Construcción del plásmido para expresión de Proteína Verde Fluorescente (GFP-LC3-II)}

Para la amplificación del marco abierto de lectura (ORF) de LC3-B NM_032514 se el diseñaron los oligonucleótidos usando herramienta bioinformática Pick primers del GeneBank y se ordenó su síntesis a IDT, INTEGRATED DNA TECHNOLOGIES. Se utilzaron para amplificar el ORF a partir de un RNA estándar (Quantitative PCR Human Reference Total RNA \#750500, Agilent). Los productos de PCR obtenidos visualizaron en geles de agarosa teñidos con bromuro de etidio y se purificaron empleando el kit Invitrogen PureLink® y para su ligación al vector pGEM-T easy Vector (Promega). Una vez clonado el amplicon en el vector, se subclonó usando los sitios de restricción Xbal y Notl al plásmido pEGFP-N1 (Clontech). Todas las transformaciones se llevaron a cabo en bacterias E. Coli XL10 Gold (Stratagene), ultracompetentes preparadas mediante el método de $\mathrm{RbCl}$ (Sambrook \& Russell, 2001). Se aislaron las colonias candidatas y se incubaron en $3 \mathrm{ml}$ de medio LB liquido durante 16 horas en agitación constante (200rpm) y finalmente se procedió a extraer

el plásmido mediante el kit Pure Link Quick Plasmid Miniprep Kit (Figura 16 A, B, C y D) (Thermo Fisher Scientific Inc $®)$. 
A) Amplificación del ORF de LC3

Genbank NM_032514

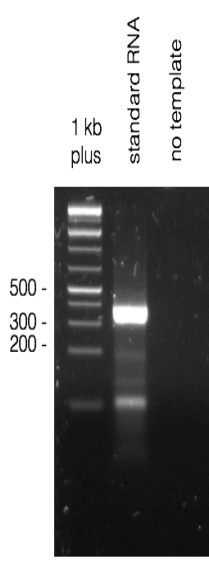

LC3 ORF

$365 \mathrm{pb}$

C)

Subclonación en pEGFP-N1

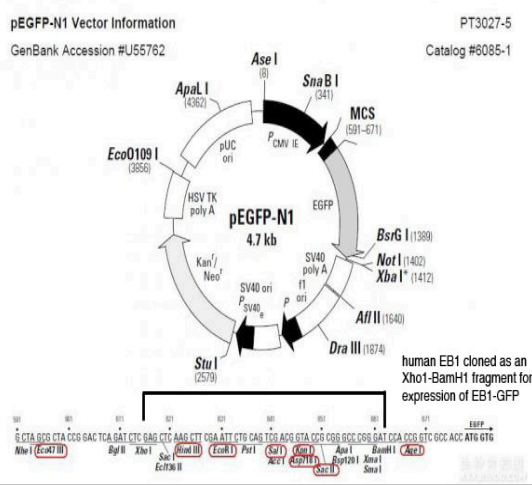

Vector de expresión en eucariontes; proteína verde fluorescente (GFP)
B)

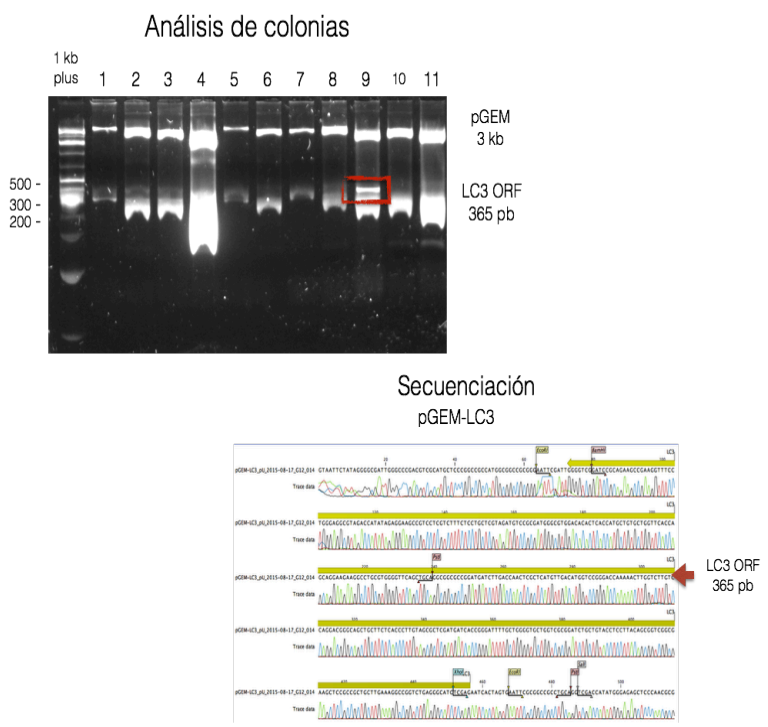

D) Subclonación en pEGFP-N1
$1 \mathrm{~kb} \quad$ pEGFP

pGEM-LC3

plus BamHI-HindIII

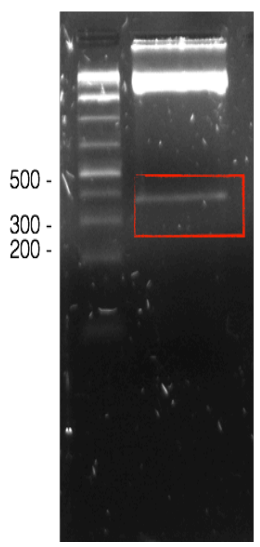

LC3 ORF

$365 \mathrm{pb}$
PEFGP

5000

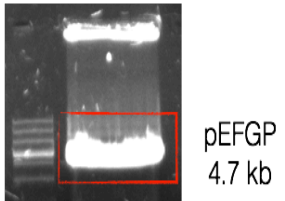

Figura 16. Ensayos de construcción de plásmido para GFP-LC3. A, B, C y D; muestra los ensayos realizados para la construcción del plásmido GFP-LC3, A) el cual fue amplificado en un RNA molde para ser ligado en el vector pGEM T easy; B) la ligación fue analizada en una batería de colonias, seleccionando la que contiene el ORF de LC3 y se comprobó su presencia mediante secuenciación; C) finalmente fue subclonada en el vector pEGFP-N1, D) la liberación de la construcción fue comprobada mediante gel de agarosa. 
Una vez extraído el plásmido de las bacterias transformadas, se secuenciaron para verificar la presencia del inserto, se realizo empleando el kit Big Dye Terminator Ready Kit (Perkin Elmer) y se analizaron en un secuenciador ABI PRISM 3130xI Genetic Analizer System de Applied Biosystems de la Unidad de Biotecnología y Prototipos (UBIPRO) de la FES-Iztacala. Como resultado se obtuvo el vector pEGFPN1-LC3, a partir del cual se expresa una proteína de fusión entre LC3 y GFP, fluorescente y análoga funcionalmente a LC3 (Figura 17)

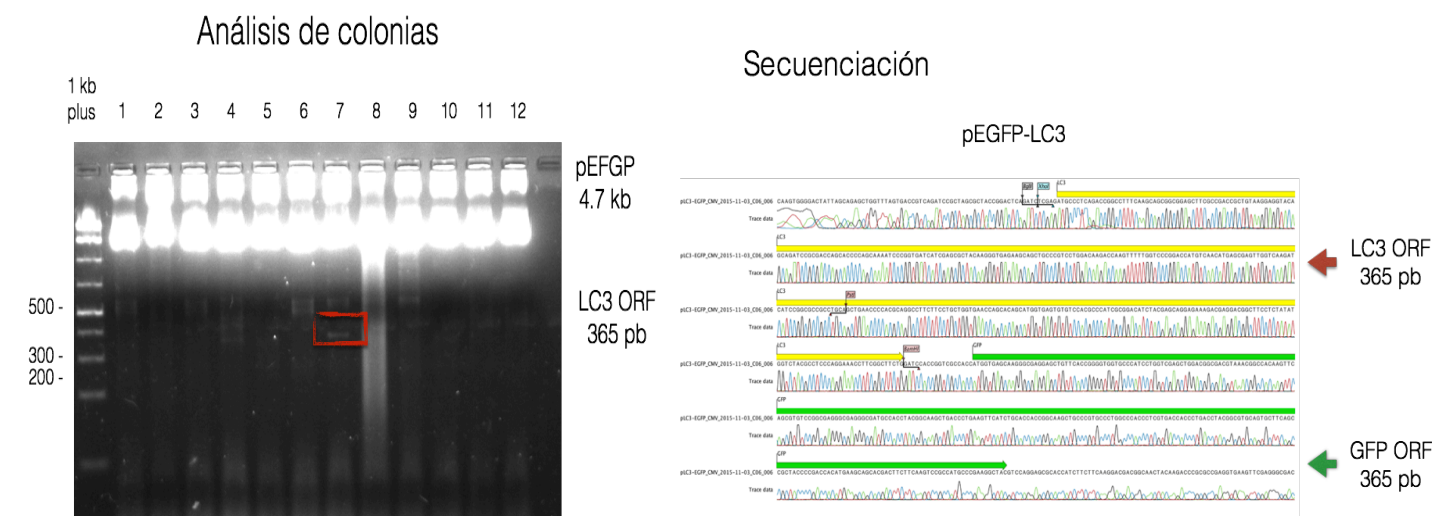

Proteína de fusión lista para transfectar

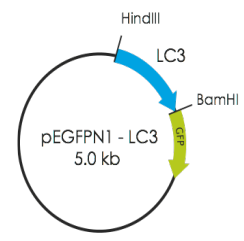

Expresión de la proteína LC3-GFP

Visualización mediante microscopía de fluorescencia

Figura 17. Ensayos de obtención de proteína de fusión. Muestra los ensayos realizados para la obtencón de la proteína de fusión. para comprobar la liberación del plásmido se empleo un gel de agarosa a 1.8\% que demuestran la obtención del plásmido, B) el fragmento liberado fue enviado a secuenciación par comprobar si era la proteína de interés y una vez comorobdo lo anterior, entonces la proteína estará lista para ser fusionada en líneas celulares de CaMa TN MDAMB-231. 


\subsubsection{Transfección por lipofectamina para expresión de Proteína Verde Fluorescente (LC3-B-GFP)}

Con el objetivo de visualizar la expresión de la LC3-B-GFP mediante microscopía de fluoresecencia, se transfectó el vector pEGFPN1-LC3 en 500000 células MDA-MB231, las cuales fueron sembradas en placas de 6 pozos, conteniendo en el fondo un cubre objetos Nunc ${ }^{\mathrm{TM}}$ de Thermo Scientific estéril de $0.22 \mathrm{~mm}$ de grosor y $15 \mathrm{~mm}$ de diámetro, con el objetivo de que las células se adhieran a el y no en la placa además de lograr su manipulación para su análisis en microscopia de fluoresecncia. Para obtener la línea estable de MDA-MB-231-GFP-LC3-B. El cultivo celular fue cosechado de las placas petri de $100 \times 15 \mathrm{~mm}$ con $800 \mu \mathrm{l}$ de tripsina y centrifugado a $1300 \mathrm{rpm}$ durante 5 minutos, posteriormente la pastilla fue resuspendida en $1 \mathrm{ml}$ de medio; se tomó una alicuota de $10 \mu \mathrm{l}$ de ésta suspención celular y se contó en camara neumbauer 500000 celulas para cada pozo; las condiciones experimentales de la placa fueron: Control (-) sin transfectar, Control (+) MOCK (vector vacio), Doxorrubicina $5 \mu \mathrm{M}$ y Met $25 \mathrm{mM}-\mathrm{Dox} 5 \mu \mathrm{M}-\mathrm{O} \times 10 \mathrm{mM}$; las células fueron expuestas a los tratamientos y mantenidas en medio DMEM/F12 (Gibco® life technologies) junto con los agentes de transfección en un incubador de $\mathrm{CO} 2$ a $37^{\circ} \mathrm{C}$ y $5 \%$ de humedad suplementadas con $2 \%$ de SFB y durante 24 horas. Posteriormente, se transfectaron las células con el plásmido pEGFPN1-LC3 empleando el agente de transfección Siport Transfection Agent (Ambion®), en este caso para la construcción de LC3-B en el vector de expresión pMIR_REPORT se utilizó el agente de transfección Lipofectamine $® 3000$ reagent (Thermo Fisher Scientific Inc. Cat. L3000-08) el cual es 
empleado para la transfección de moléculas grandes. Para la transfección de LC3-B, se generaron primero los liposomas a través de dos mezclas; la primera contenía 10 ul de lipofectamina, $4 \mu \mathrm{l}$ de Plus reagent P3000 (Thermo Fisher Scientific Inc. Cat. 100022057) y $236 \mu \mathrm{l}$ de Opti-MEM 1X (Gibco Life Thechnologies Cat. 31985-070) y posteriormente a los liposomas se les incorporó la mezcla 2, que contenía los correspondientes ácidos nucleicos, ésta mezcla contenía $5 \mu \mathrm{g}$ de plásmido, $2 \mu \mathrm{g}$ de $\beta$-Galactosa y c.b.p $125 \mu$ l de Optimem (Tabla 4); el periódo estándar de transfección en ésta línea celular fue de 24 horas. Es importante mencionar que después de haber preparado el Mix1 y el 2 haya un periodo de incubación de las mezclas de 15 minutos, con el objetivo de permitir la formación de los liposomas y de la encapsulación del plásmido respectivamente; despés de ello las mezclas pueden ser adicionadas a las células. 


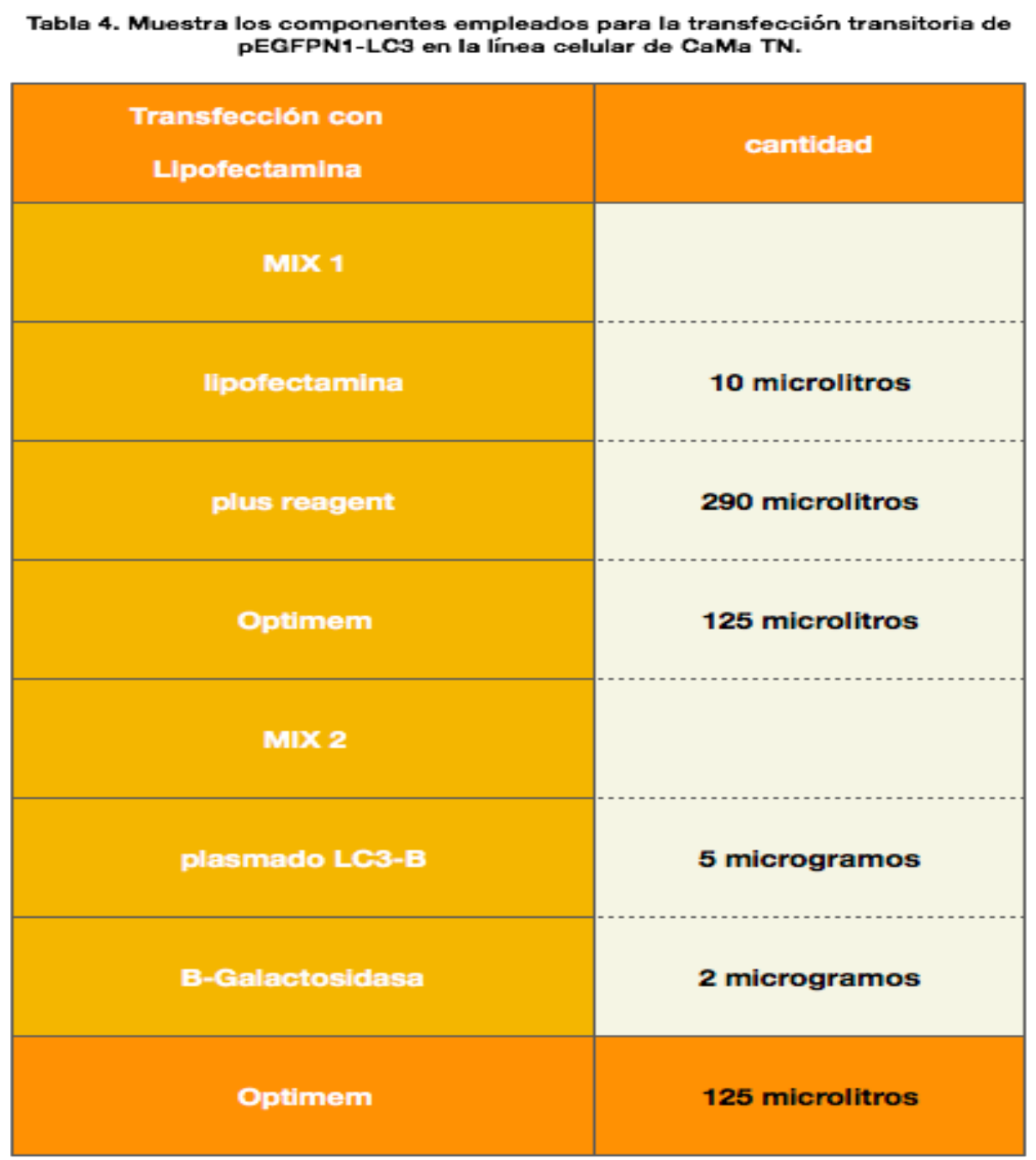

Tabla 4. Componentes empleados en la transfección transitoria de pEGFPN1-LC3 en líneas celulares de CaMa TN

Después de 24 horas de transfección se retiró el medio de las células y cuidadosamente los pozos fueron lavados con PBS 10X frío, posteriormente para la fijación de las células se adicionó $1 \mathrm{ml}$ de paraformaldehido al 3.7\% a temperatura ambiente durante 30 minutos y posteriormente se realizaron 3 lavados con PBS 10x frío. Para la permeabilizar las células se adicionarón 100ul de PBS-Tritón X-100 al 0.5\% por 3 minutos y se realizarón 3 lavados con PBS 10X frío. Finalmente, los 
cubreobjetos con las células adheridas y tratadas, se les adicionó 15 ul de Vectashield con DAPI (Vector Laboratories Inc. Cat. H1500) y cuidadosamente los cubreobjetos fueron retirados de la placa y se montaron cara abajo en un portaobjetos, para una mejor adhesión se dejaron 30 minutos a temperatura ambiente y en oscuridad y posteriormente para eliminar exceso de Vectashield las laminillas fueron lavadas cuidadosamente con agua MilliQ fría. Las laminillas se almacenaron a $-20^{\circ} \mathrm{C}$ y protegidas de la luz para su análisis en microscopio confocal de la Unidad de Biomedicina (UBIMED) en la FES-Iztacala con el apoyo de la Dra. Norma Laura Delgado Buenrostro.

\subsubsection{Análisis de ultraestructura mediante Microscopía de Transmisión Electrónica (TEM)}

El microscopio electrónico de transmisión (TEM, por sus siglas en inglés) aprovecha los fenómenos físico-atómicos que se producen cuando un haz de electrones suficientemente acelerado colisiona con una muestra delgada convenientemente preparada. Cuando los electrones colisionan con dicha muestra, parte de ellos son dispersados selectivamente en función de su grosor y del tipo de átomos que la forman, generando una imagen sobre una cámara $C C D$ que permite miles de aumentos con una altísima resolución (Gilmore, 2008). La observación del interior celular a grandes aumentos permite analizar con precisión distintos orgánulos y estructuras celulares, como mitocondrias, compartimento endosomal, retículo endoplásmico, núcleo, membrana plasmática y otros. 
Con el objetivo de obtener información de alta resolución, a nivel de ultraestructura se evalúo la inducción de autofagia mediante la formación de autofagolisosomas en la línea celular de CaMa TN expuesta a Doxorrubicina y a la triple terapia farmacológica. Células MDA-MB-231 expuestas a Doxorrubicina 5uM y a la triple terapia Met 25mM-Dox $5 \mu \mathrm{M}-\mathrm{O} \times 15 \mathrm{mM}$ y un grupo sin tratamiento fueron sembradas en placas Petri de 100x15 mm. Cuando alcanzaron una cpnfluencia del $80 \%$ fueron tripsinizadas y cosechadas en un tubo falcon de $15 \mathrm{ml}$; posteriormente se centrifugaron a 1300 rpm durante 3 minutos, se descartó el sobrenadante y el pellet fue resuspendido en PBS 1X estéril y frío. Este procedimiento de lavado se realizó 5 veces con el objetivo de eliminar toda la tripsina posible. En el ultimo lavado el pellet celular fue trasferido a tubos eppendorf de $2.0 \mathrm{ml}$ para comenzar con el tratamiento para su análisis en el MTE (Microscopio de Transmisión Electrónica). Después de los lavados con PBS 1x se procedió a lavar con una solución de tampón de fosfato sódico al $0.1 \mathrm{M}$ a pH 7.4. Posteriormente se llevó a cabo la fijaciñon de las células con una solución de paraformaldehído al $2 \%$ y glutaraldehído $2.5 \%$ en tampón fosfato de sodio $0.1 \mathrm{M}$ a $\mathrm{pH}$ 7.4. El pellet cellular se resuspende en la solución fijadora a $4^{\circ} \mathrm{C}$ durante $3 \mathrm{~h}$. Tras la fijación se realizaron lavados sucesivos con tampón fosfato de sodio al $0.1 \mathrm{M}$. Después de éste periodo de fijación, con la menor intensidad de luz, se tiñeron las células adicionando $1 \mathrm{ml}$ de tetróxido de osmio al $1 \%$ en tampón fosfato de sodio $0.1 \mathrm{M}$, durante $1 \mathrm{~h}$ a $4^{\circ} \mathrm{C}$. Para eliminar el tetraoxido de osmio se realizaron lavados sucesivos del pellet cellular con agua bidestilada aproximadamente durante cuatro horas, desechando cada vez el sobrenadante. En 
el último lavado no se resuspendieron las células y únicamente se cambió el agua utilizándose una velocidad de centrifugación de 12000 rpm para obtener un sedimento cellular muy compacto en el fondo del tubo Eppendorf. A continuación, se deshidrató el pellet cellular utilizando disoluciones de Etanol; se inicia el proceso con una concentración al $100 \%, 80 \%, 75 \%, 60 \%, 50 \%, 30 \%$ y por ultimo al $20 \%$. Se realizaron tres tratamientos de 10 minutos para cada concentración de etanol; todos los lavados se realizaron sin resuspender las células. Después de la deshidratación se procedió a la inclusion de los pellets celulares en resina Spurr de baja densidad, empleando el kit Spurr Low-Viscosity Embedding kit de SIGMA No de Cat. EM0300 en las siguientes cantidades: NSA (endurecedor) 26.0g, D.E.R 736 (flexibilizador) 6.0 g, DMAE (acelerador) 0.4g y DBP (plastificante) $0.8 \mathrm{~g}$ y c.b.p $100 \mathrm{ml}$ de medio de inclusión (resina) contenida en el mismo kit. Los componentes, una vez pesados, se mezclaron homogéneamente con un agitador magnético. El pellet celular fue tratado durante $4 \mathrm{~h}$ con una dilución 1:3 de resina Spurr:acetona; éste procedimiento se repitió tres veces. Después de esto el tratamiento final de la muestra se realizó con resina pura durante 5 horas, a continuación, se cambió y las inclusiones se dejaron toda la noche en agitación lenta. Tras la inclusión, se procedió a la confección de los bloques en unos moldes adecuados que se llenaron de resina y en uno de los extremos se depositó una pequeña fracción de la muestra embebida en la resina. Para permitir la polimerización de la resina los moldes fueron introducidos en una estufa a $60^{\circ} \mathrm{C}$ durante 48 horas. La obtención de los cortes ultra finos $(5 \mu \mathrm{m}$ de espesor y 3mm de diámetro) fue llevada a cabo con el apoyo de la Escuela Nacional de Ciencias Biológicas del Instituto Politécnico Nacional, en el Laboratorio Central de 
Instrumentación de Microscopía, Depto. Investigación con la colaboración del Dr. Edgar Oliver López Villegas, quien realizó los cortes y la Dra. Ma del Rosario Mellado Espinoza quien realizó el análisis de los cortes con una resolución de $2 \mu \mathrm{m}$ en el Microscopio de Transmisión Electrónica Modelo JEOL JEM 1010 TEM; analizadas en el software GI image analysis.

\section{RESULTADOS}

\subsection{Efecto de los fármacos individuales y la triple terapia en la activación de la apoptosis en la línea celular MDA-MB-231}

Para la evaluación de la muerte celular por apoptosis en la línea celular de CaMa TN MDA-MB-231 expuesta a Dox, Met, Ox de manera adyuvante y a la triple terapia DoxMetOx, se realizaron ensayos de inmunotransferencia empleando marcadores moleculares clave involucrados en la apoptosis mitocondrial, tales como PARP-1 y caspasa 3. Con ellos se puede observar que cuando las células fueron expuestas a los fármacos en monoterapia (Figura 18 A-C), Dox y Ox aumentaron ligeramente la expresión de pro-caspasa-3, a las 12 y 24 horas respectivamente, mientras que en Met se observa una mayor detección de esta a partir de las 4 horas de exposición. En lo que a PARP-1 respecta, Dox y Ox muestran ligera detección de ésta a partir de las 4 horas; este efecto se mantiene constante hasta las 24 horas, sin embargo en Met se observa activación de PARP-1 partir de las 12 horas pero con mayor intensidad en su expresión en comparación con Dox y Ox. En lo que respecta a las terapias combinatorias de MetOx se observó ligera inducción de PARP-1 a partir de 
las 12 horas de exposición e inducción de caspasa-3 en el tiempo más corto y un ligero aumento a las 12 horas, sin embargo a las 24 horas se puede ver que éste efecto va declinando, lo que siguiere que el efecto de ésta terapia probablemente tenga su pico máximo de efectividad en ese tiempo y posteriormente se reactiven los mecanismos que le permitan a la célula continuar con la tumorigénesis. En la triple terapia DoxMetOx de manera conjunta se indujo una regulación positiva de PARP-1 y caspasa-3 efectora, escindidos respectivamente a partir de las 4 horas de exposición, efecto que en PARP-1 se mantuvo constante hasta las 24 horas y en caspasa-3 fue en aumento, lo que siguiere que probablemente la sinergia de la triple terapia incrementa su efecto de manera gradual, induciendo fuertemente la apoptosis y éste efecto permanezca por un tiempo más largo que 24 horas. Los resultados de Western blot demostraron que el efecto de las terapias es dependiente del tiempo y que la inducción de la apoptosis por DoxMetOx es dependiente de PARP-1 y caspa-3 efectoras en la línea celular de cáncer de mama MDA-MB231 por, esta terapia muestra una mejor eficacia anti-tumorigénica con respecto a Met. 


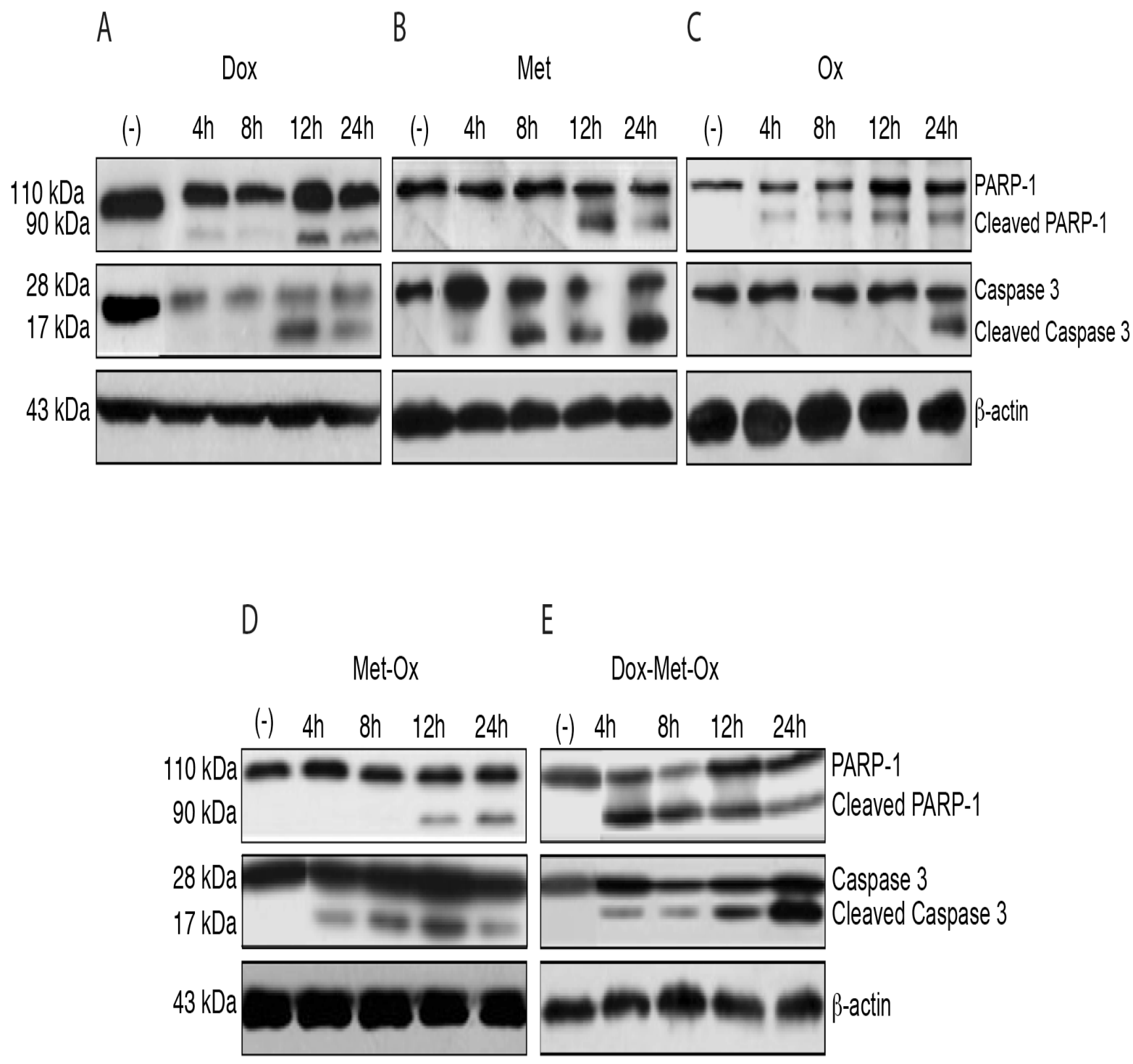

Figura 18. Detección de marcadores moleculares en la activación de la Apotosis identificados por Western Blott. A-C. Deteccción de marcadores moleculares en la activación de Apoptosis identificados por Western Blot; los fármacos Dox, Met y Ox y la triple terapia DoxMetOx fueron administrados a las líeas celulares de CaMa TN en 4 diferentes tiempos. A) Inducción de apoptosis identificada por Western blot detección de PARP-1 y caspasa 3. A) Dox como terapia de primera línea no muestra activación significativa de éstos marcadores de apoptosis, sin embargo (E) DoxMetOx activa PARP-1 y caspasa-3 a partir de las 4 horas, su efecto permaneció a lo largo de las 24 horas. 


\subsubsection{Efecto de DoxMetOx en la probable inducción de autofagia a través de la activación de la proteína LC3 y la inhibición de la fosforilación de mTOR}

De igual manera, se emplearon las terapias de manera adyuvante: Dox, Met y Ox, la teraplia doble MetOx y la triple terapia DoxMetOx en las células de CaMa TN MDAMB-231 y se realizaron ensayos para la detección de marcadores de inducción de autofagia: LC3-B, mTOR y p-mTOR. Los resultados obtenidos en Dox, Met y Ox (Figura 19 A-C) no muestran participación importante de LC3-B. A pesar de que se observa una ligera lipidación de LC3-II a partir de las 24 horas, no es significativa como lo que se observa en las terapias combinadas; en el caso de la terapia de primera línea Dox se observa la inducción de LC3-II a partir de las 12 horas y su efecto declina en las 24 horas, lo que probablemente sea un efecto transitorio y no permanente de la inducción de autofagia. Es importante mencionar lo que se obtuvo en Dox con el marcador para p-mTOR (Figura 19 A), donde se observa una detección abundante de ésta protena, lo que nos suguiere que Dox no tiene efectos positivos en la inhibición de la vía mTOR y que por tanto no se puede sustentar la hipótesis de que la Dox de manera adyuvante no promueve la inducción de autofagia, pero si de apoptosis. En lo obtenido con Ox, se puede observar ligera disminución de la fosforilación de mTOR, esto debido al papel que juega en la inhibición del efecto Warburg, lo que suguiere que la inactivación de p-mTOR probablemente conlleve a la disminución de la LDH-A en las células tumorales y que por lo tanto sean dos mecanismos que se lleven a cabo de manera dependiente (Figura $19 \mathrm{C}$ ). 
En lo que respecta a las terapias combinadas, en MetOx se observa ligera inducción de LC3-II a partir de las 4 horas y el efecto permaneció hasta las 24, mientras que en la inactivación de p-mTOR con ésta doble terapia, ligeramente disminuye a partir de las 12 horas y permanece a las 12 horas posteriores. En la triple terapia DoxMetOx se observa de manera importante la inactcavión de la vía p-mTOR y de manera conjunta un incremento significativo en la conversión de LC3-I a LC3-II en su forma hiperlipidada a partir de las 4 horas y su efecto permanece de manera considerable hasta el final de la fase experimental (Figura 19 E), lo que sugiere la inducción de apoptosis mitocondrial o dependiente de caspasas y autofagia de manera conjunta en las células tumorales en etapas tempranas. 
A B

Dox

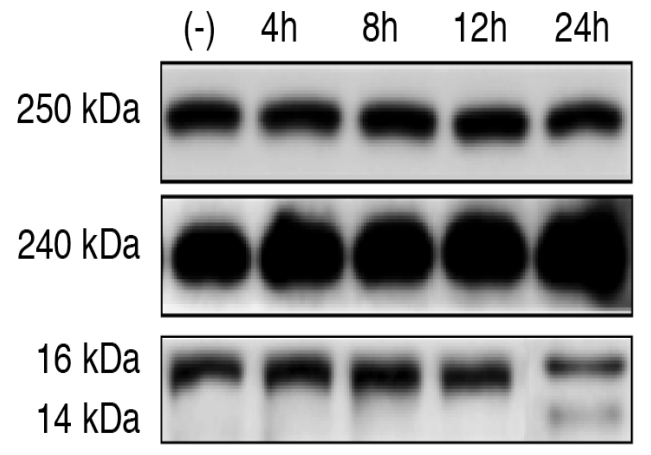

$43 \mathrm{kDa}$

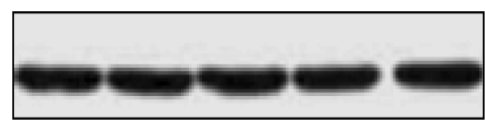

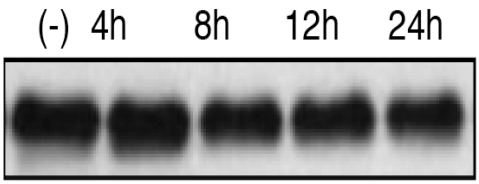
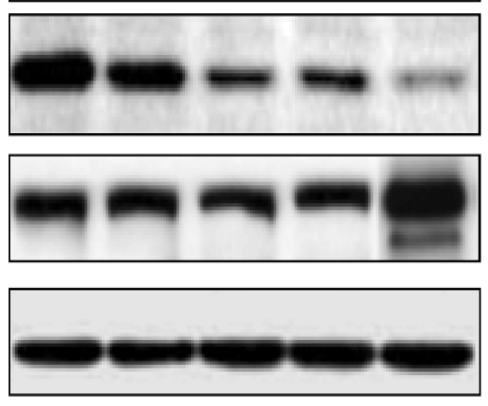

C

Ox
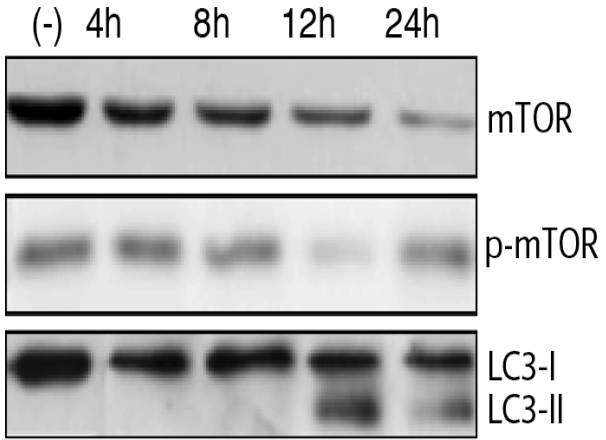

$\beta$-actin
D

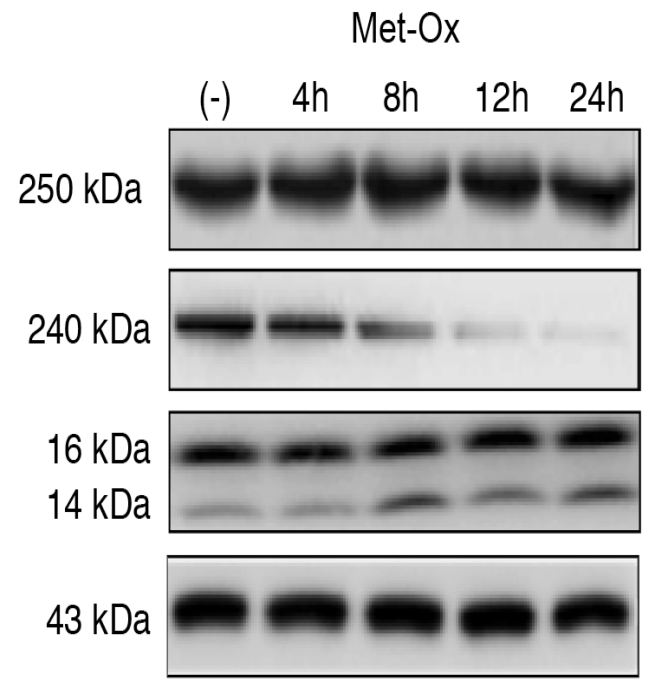

E

Dox-Met-Ox
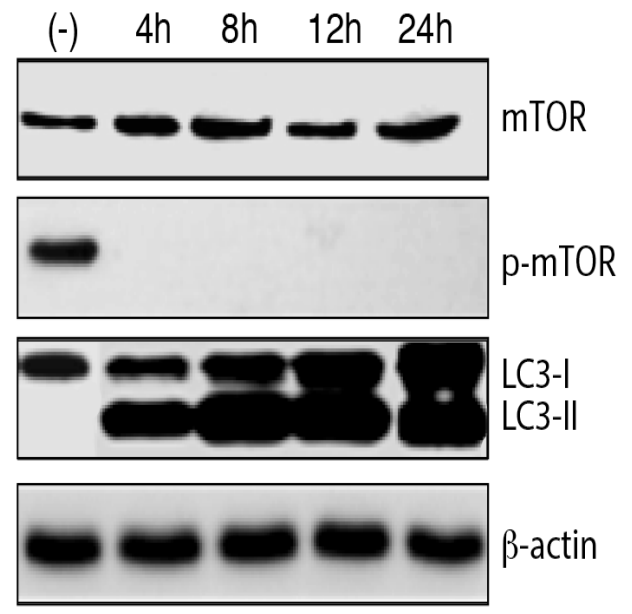

LC3-I

LC3-II

$\beta$-actin

Figura 19. Detección de marcadores de autofagia mediante Western Blott. A-E. Muestra la activación temprana de la autofagia e inhibición de p-mTOR. DoxMetOx fue capaz de inhibir p-mTOR a las $4 \mathrm{~h}$, y el efecto se mantuvo hasta $24 \mathrm{~h}$. Lo mismo ocurrió con la acumulación de LC3-II, a diferencia de las monoterapias o los duplets. 


\subsubsection{DoxMetOx promueve la inhibición de la expresión de la LDH-A a nivel de expresión de mensajero}

Para observar si LDH-A -marcador de la glucólisis- se encuentra inhibida a nivel de expresión de mensajero y de proteína, se realizaron experimentos de RT-PCR y Western Blot. Los resultados obtenidos muestran de manera importante que el empleo de Ox como inhibidor específico de LDH-A, muestra una respuesta de inhibición dependiente del tiempo a partir de las 12 horas de exposición del fármaco con las células tumorales de CaMa TN MDA-MB-231, efecto que permanece hasta la fase final del experimento, probablemente requiera de un tratamiento más prolongado o una concentración más alta ya que se observó una inhibición incompleta de la LDH-A (Figura 20 A). En lo que respecta a Dox se observa que no existe inhibición de la expresión de LDH-A en ninguno de los tiempos de la experimentación, lo que sustenta que el blanco de esta terapia no es incide sobre la glucólisis aerobia. En MetOx observamos que al adicionar Met a Ox probablemente se produjo un efecto sinérgico en esta combinación, pues moderadamente induce inhibición de la expresión de la LDH-A a partir de las 4 horas, efecto que se mantuvo hasta las 24 horas. Sin embargo, en la triple teraopia observamos que cuando se adicionó Dox al dúplex Met-Ox, de manera considerable la expresión y detección de la LDH-A no se detectó mediante RT-PCR de punto final ni en la transferencia de Western Blot desde las cuatro horas de tratamiento y el efecto persistió hasta las 24 horas. 

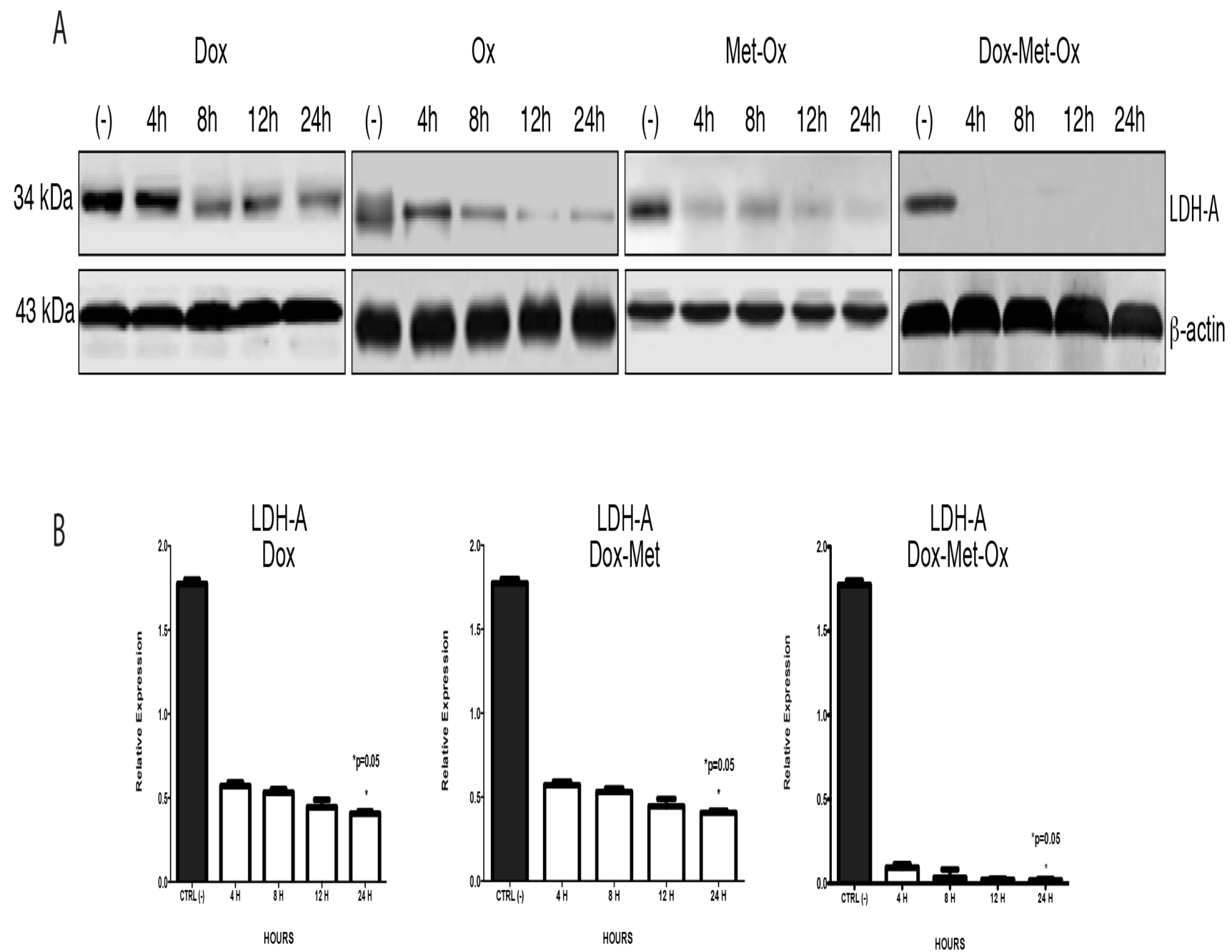

Figura 20. Inhibición de la LDH-A por la triple terapia. A-B). Muestra la inhibición de LDH-A por triple terapia. Los niveles de mRNA y proteína se analizaron por qRT-PCR y western blot, respectivamente. A) DoxMetOx inhibió los niveles de proteína de LDH-A. B) los niveles de ARNm fueron indetectables cuando se administró DoxMetOx. 


\subsubsection{Dox no promueve muerte celular programada y su efecto citotóxico induce daño celular masivo}

Con la finalidad de sustentar si los resultados en la detección de los marcadores de apoptosis y autofagia: PARP-1, Caspasa-3, LC3-II y activación de mTOR respectivamente corresponden con los cambios morfológicos en la integridad y/o patrón de distribución de los orgánulos celulares; los evaluamos a nivel de ultra estructura en la línea celular de CaMa TN expuesta a Dox y DoxMetOx. Este experimento permitió observar la inducción de morfologías características de apoptosis como son la formación de evaginaciones o de autofagia a través de la formación de vesículas o autofagosomas que envuelven los orgánulos, que como se sabe, ambas estructuras juegan un papel importante en la fase final de ambos tipos de muerte. En la Figura 21, las líneas celulares de CaMa TN MDA-MB-231 (panel A), MDA-MB-668 (panel B) y BT-20 (panel C) mostraron morfología alterada en toda la célula como consecuencia de la terapia adyuvante Dox; de manera considerable y sin excepción en ninguna de las 3 líneas (Figura 21 A, B y C). Se observaron cambios en toda su estructura, resultando daño celular masivo a la exposición de la terapia en las primeras 4 horas, efecto que se mantuvo hasta el final de la fase experimental que fue de 24 horas, se muestra que las células sufrieron una importante reducción citoplasmática, mostrando contenido celular amorfo, asi como perdida de mantenimiento de la integridad de la membrana celular y de los orgánulos, además de escapatoria de elementos citoplasmáticos, autolisis y excesivos restos celulares. Todo lo anterior promovido por el estrés al que fue 
sometida la línea celular con la exposición a Dox, lo que se sugiere muerte celular de tipo III (necrosis), probablemente la estructura celular se vio alterada por la exposición de Dox a $5 \mu \mathrm{M}$ en las 3 líneas celulares, aunque la más susceptible de éstos cambios morfológicos fue la linea cellular BT20, a diferencia de MDA-MB-231 Y MDA-MB-468. Por su parte, las células no tratadas (control) presentaron una ultraestructura normal con cromatina laxa y orgánulos bien conservados y con claridad del núcleo. Estos datos coinciden con lo que obtuvimos en los ensayos de a nivel de proteína, donde no se observa en ninguno de los tiempos la inducción de apoptosis ni autofagia con Dox, si bien existe una ligera activación de LC3-II y PARP1 a las 24 horas probablemente es atribuible a un efecto a nivel basal en un cierto porcentaje de la población celular. 


\section{DOXO CaMa TN}

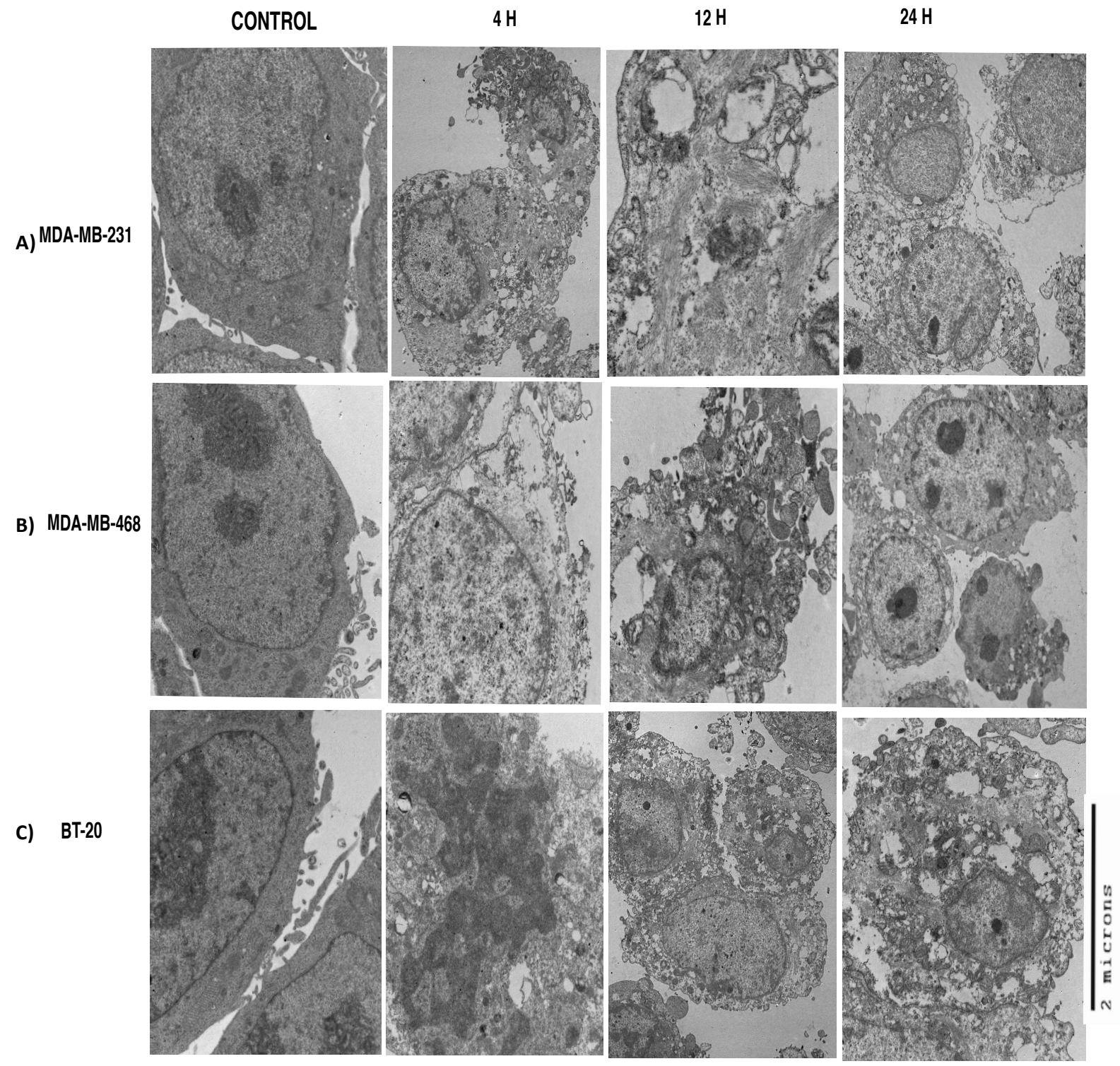

Figura 21. Análisis de 3 lineas de CaMa TN mediante TEM. A, B y C. Muestra análisis a nivel de ultraestructura en Microscopia de Transmisión de Electrones (TEM) en 3 líneas celulares de CaMa TN. La exposición de 5uM de Dox en las líneas celulares durante 3 tiempos de exposición (4, 12 y 24 horas), indujo daño celular masivo; se observan orgánulos amorfos y perdida del mantenimiento de la integridad de la pared celular, lo que suguiere tipo de muerte III (necrosis) debido a los efectos citotoxicos que Dox induce. 


\subsubsection{El empleo de DoxMetOx promueve formación de autofagolisosomas por activación de Autofagia}

Para sustentar si los resultados en la detección de los marcadores de autofagia: LC3Il y activación de mTOR a nivel de proteína coinciden con los cambios estructurales que la célula presenta con la exposición de Dox y DoxMetOx analizamos por microscopía de fluoresencia la formación de los autofagosomas ya que juegan un papel importante en la fase final de éste tipo de muerte.

En la Figura 22 las líneas celulares de CaMa TN MDA-MB-231 (panel A), MDA-MB668 (panel B) y BT-20 (panel C); tratadas con la triple terapia DoxMetOx mostraron de manera considerable cambios importantes en su estructura durante las primeras 4 horas, resultando inducción de apoptosis y autofagia (indicado con flehas). Este efecto aumentó hasta el final de la fase experimental de 24 horas, como se puede observar en los 3 paneles A, B y C. ; se observó la formación de vesículas de doble membrana que secuestra orgánulos dañados y en algunos casos se observaron evaginaciones en la superficie de la membrana celular que muy probablemente se generaron debido a la deprivación de nutrientes o la baja energética que la triple terapia ocasionó. Al mismo tiempo, también se observó integridad de las membranas y del ambiente celular, algo similar a lo que se muestra en los controles sin tratamiento. Se suguiere muerte celular de tipo I y II (apoptosis y autofagia respectivamente). 


\section{F CaMa TN}

A) MDA-MB-231

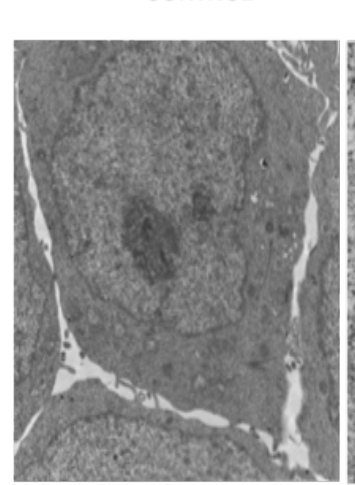

$4 \mathrm{H}$

$12 \mathrm{H}$
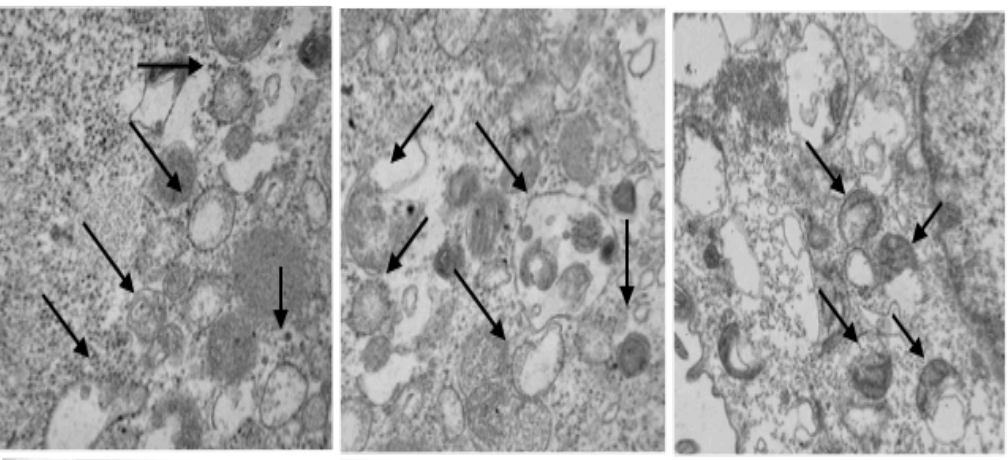

B)
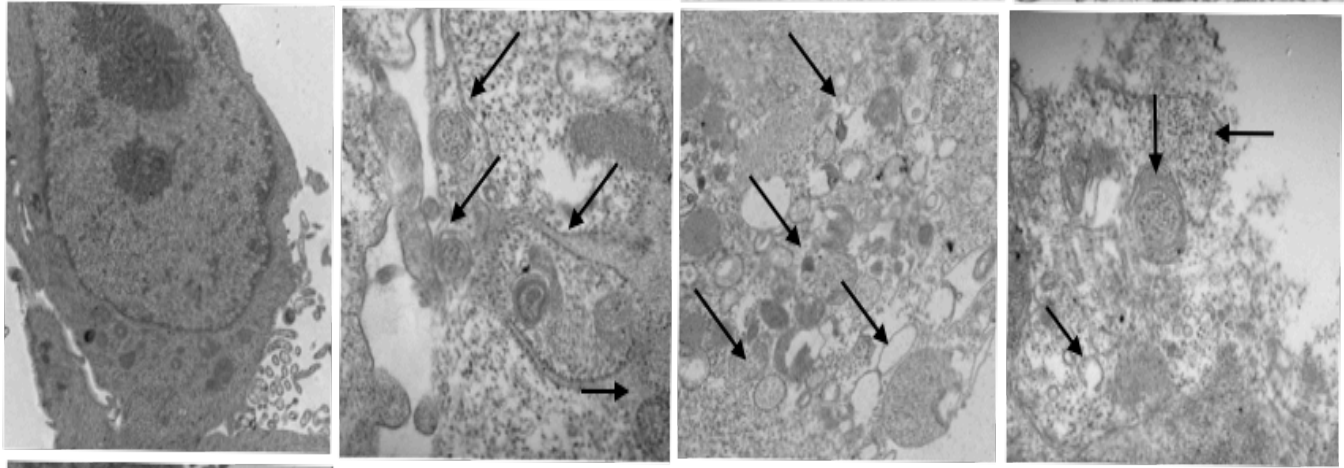

C) $\mathrm{BT}-20$
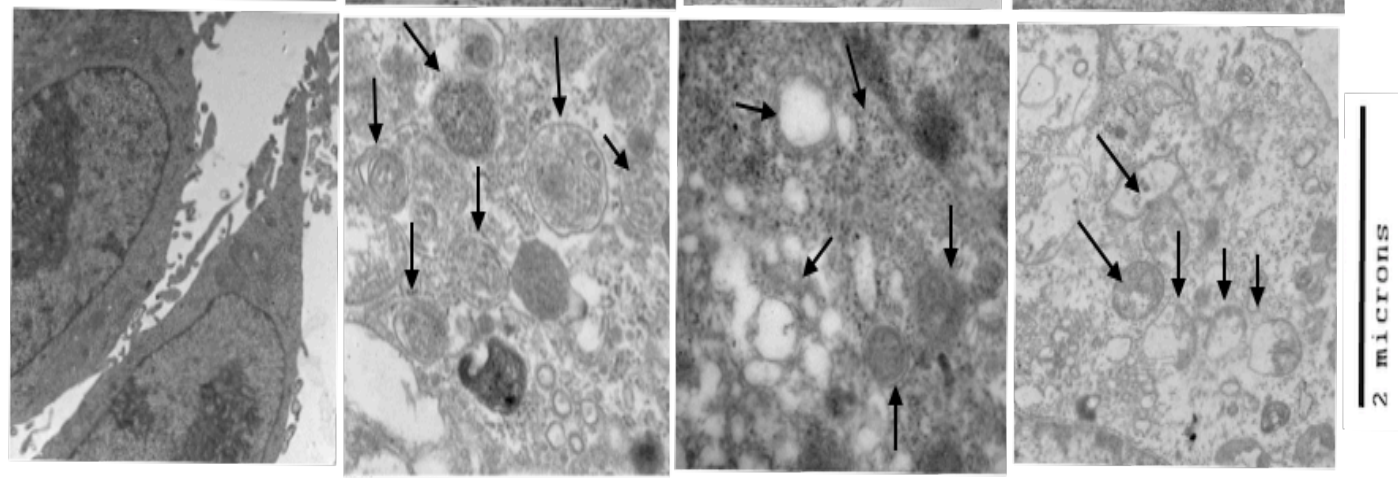

Figura 22. Análisis de ultraestructura mediante TEM de la terpia DoxMetOx. A, B y C. Muestra análisis a nivel de ultraestructura en Microscopia de Transmisión de Electrones (TEM) en 3 líneas celulares de CaMa TN. A, B y C) MADMB-231, MDA-MB-468 y BT20. La exposición DoxMetOx en las líneas celulares durante 3 tiempos de exposición (4, 12 y 24 horas), indujo dos importantes mecanismos de muerte celular: Apoptosis y Autofagia; las flechas señalan vesículas de doble membrana con desechos de orgánulos lo que indica promoción de autofagia y también envaginaciones en membrana celular, lo que suguiere promoción de apoptosis. 


\subsubsection{Detección de autofagia mediante la localización intracelular de autofagosomas a través de GFP-LC3 inducida por DoxMetOx}

El sistema de marcador fluorescente de autofagia, el GFP-LC3, nos permite determinar de manera contundete la inducción de autofagia promovida por la triple terapia (DoxMetOx). El marcador más utilizado para el autofagosoma es el LC3, un homólogo de mamífero de Atg8 (Tanida et al., 2008). El conjugado LC3 (un homólogo de mamífero de Atg8) y fosfatidil inositol-3P (por sus siglas en inglés, PE) son marcadores que permiten la identificación de las estructuras autofágicas mediante microscopía de fluorescencia y la localización de GFP-LC3 representa la formación del autofagosoma; la emisión verde más intensa representa la funcionalidad del sistema GFP-LC3 en la inducción de autofagia.

Como era de esperarse, en las imágenes obtenidas en el microscopio confocal de las lineas celulares de CaMa expuestas en Dox nuevamente muestra su efecto citotoxico en las células expuestas a ésta terapia, pues no se observa efecto en la inducción de la conjugación de LC3-PE, por tanto no existieron células punteadas positivas para LC3, sino que por el contrario se produjo el mismo efecto que se observó en la TEM, severo daño celular masivo (Figura 23 D). Esto comprueba lo que ya se sabe a cerca del mecanismo de acción de Dox, que no es una terapia efectiva para incidir sobre el metabolismo de la célula tumoral. En lo que respecta a la triple terapia (DoxMetOx), podemos observar aumento de la actividad autofágica en las 3 líneas celulares expuestas a la terapia, debido a que existe mayor número de células 
punteadas positivas para LC3 endógeno a las 24 horas de transfección (Figura 23 A1, 2 y 3). Con base en esto, nuestros resultados son consistentes con los ensayos a nivel de proteína y las TEM; pues a partir de las 4 horas de exposición se vió detección considerable de LC3-I y II asi como, efecto que perm,aneció hasta las 24 horas. Al igual que en las TEM con las células tratadas con la triple terapia observamos formación de vesículas que envolvían algunos orgánulos. Con base en lo anterior podemos sustentar fuertemente que DoxMetOx participa en la promoción de autofagia, lo que probablemente conduzca a la célula tumoral a morir a través de éste mecanismo debido al estrés que se genera en el microambiente por la falta de nutrientes. 
A)

1)

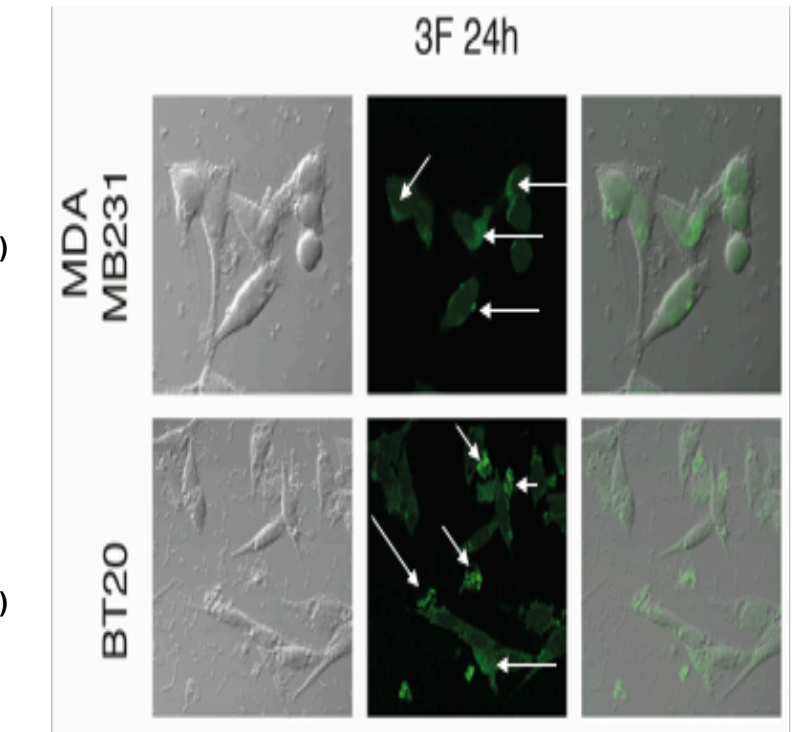

3)

B)

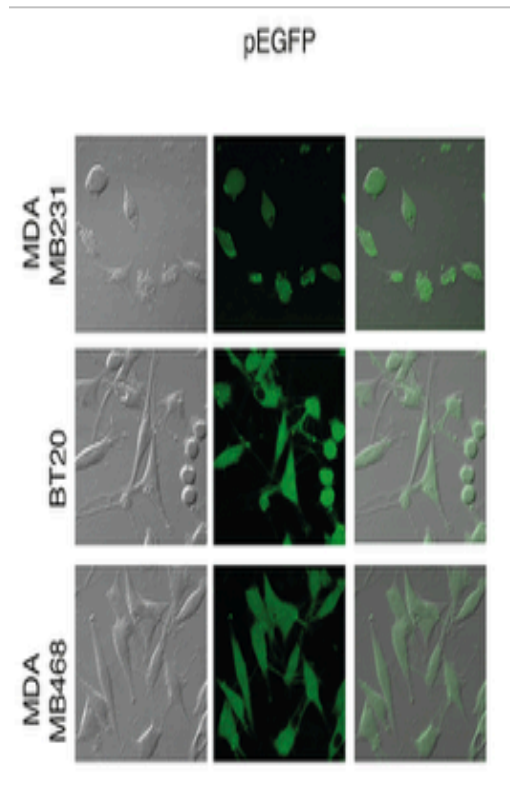

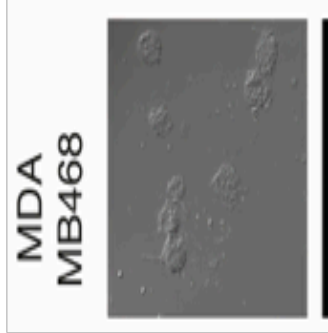

C)
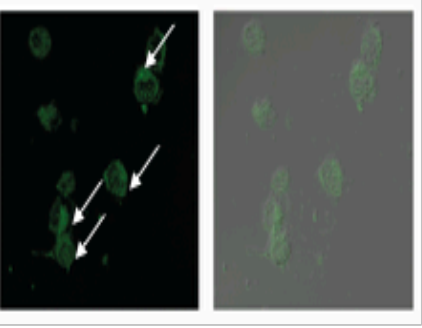

D)

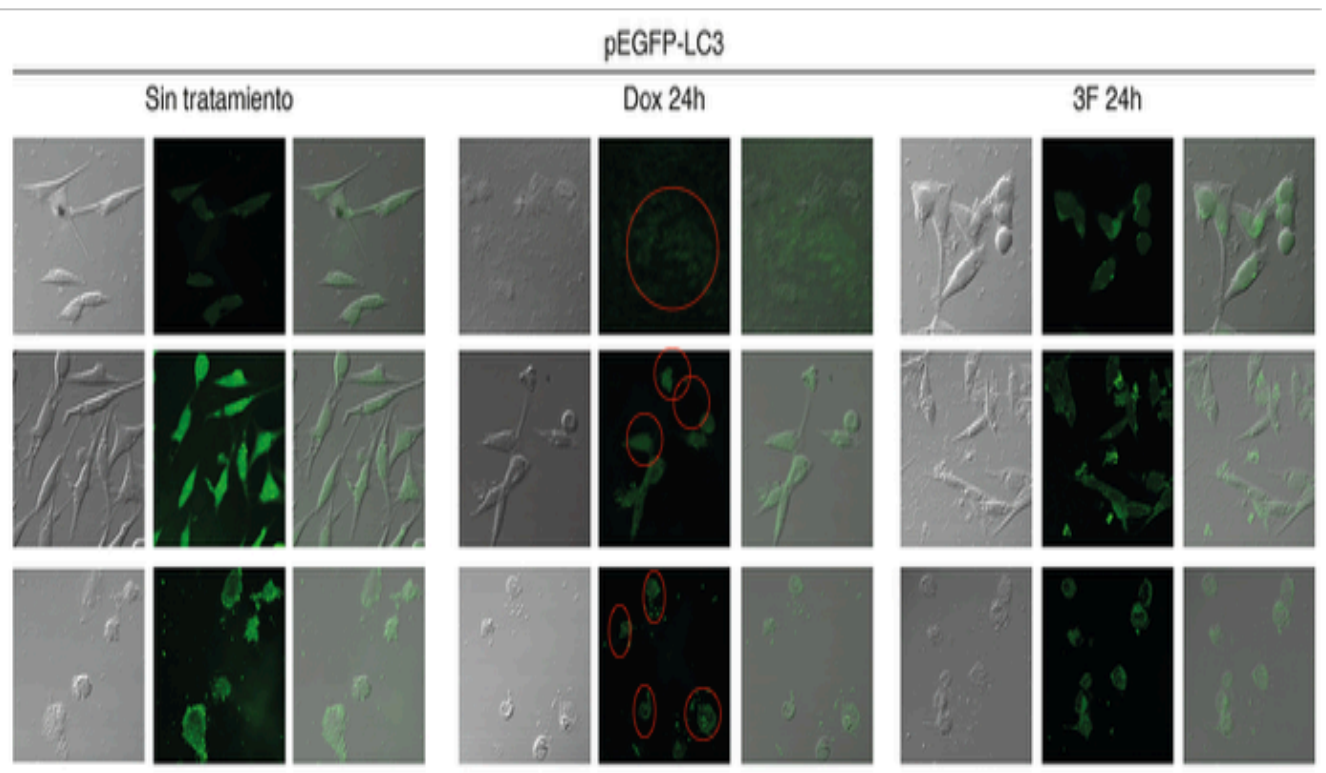

Figura 23. Expresión de GFP-LC3 en 3 líneas celulares de CaMa TN con las terapias Dox y DoxMetOx. A1,2,3-D. Muestra la expresión transitoria de GFP-LC3 en líneas celulares de CaMa TN: A1) MDA-MB-231, A2) MDA-MB-468 y A3) BT20 expuestas a DoxMetOx y D) expuestas a Dox. La triple terapia promueve formación de autofagolisosomas (flechas), estructuras contundentes en la promoción de la autofagia; mientras que Dox nuevamente induce daño celular masivo (círculos) a las 24 horas de transfección respectivamente. 


\section{DISCUSIÓN}

El CaMa es un problema de salud publica a nivel mundial y es considerado como una de las principales causas de muertes relacionadas con el cáncer en mujeres (Jemal et al., 2011). En México desde el 2006 la mortalidad por este tipo de cáncer ha ido en aumento, pasando de ocupar el segundo lugar en incidencia y mortalidad a ocupar el primer lugar (Chávarri-Guerra et al., 2012). El fenotipo clínicamente referido como TN o Basal-like representa el de peor pronóstico en términos de sobrevivencia y periodo libre de enfermedad y actualmente no existe una terapia exitosa (Mc Carthy et al; 2012)(Creighton, 2012). Recientemente se ha centrado el interés de estudiar al cáncer desde una perspectiva metabólica, a través de la desregulación energética de la celula tumoral. (DeBerardinis \& Chandel, 2016). Una de las enzimas que se ve modificada de manera importante en esta alteración metabólica es la sobre expresión de la LDH-A, la cual juega un papel importante como marcador pronóstico para la detección de diversos tipos de cáncer (Yu et al., 2017). De manera importante observamos que con el empleo de MetOxDox se promueve el bloqueo de la LDH-A y la FOSOX, inhibendo la glucólisis aerobia y la vía mTOR en las células tumorales, mientras que la mayoría de las células no tumorales no se ven afectadas con el uso de esta terapia. Con base en lo anterior consideramos que la inhibición del metabolismo de la célula tumoral es un blanco terapéutico prometedor para el tratamiento del CaMa y de otros tipos de cáncer. En este trabajo se demostró en ensayos in vitro a nivel molecular que la combinación farmacológica de DoxMetOx induce la inhibición de la fosforilación de mTOR, de la expresión de la LDH-A y de 
manera simultánea la inhibición de la síntesis de ácidos nucléicos; promoviendo la reactivación de la muerte celular por apoptosis e inducción del flujo autofágico. Estos eventos biológicos también se vieron reflejados en el modelo animal que se estableció previo a éste trabajo, donde se observó a través de microPET la dramática reducción de la masa tumoral en el grupo de animales tratado con la combinación de fármacos inhibidores del metabolismo tumoral: DoxMetOx (García-Castillo et al., 2017). Los resultados in vitro alcanzados en este proyecto coincidieron con diversos trabajos publicados que demuestran en algunos tipos de cáncer las implicaciones del empleo de Met, Ox y Dox sobre el efecto antiproliferativo a través de la inhibición de la LDH-A, la inducción de apoptosis dependiente de casapasas y la activación de autofagia (Xie et al., 2009) (Reddy, 2011) (Bernier J, 2016). Lo anterior sustenta que la depleción del metabolismo energético de la célula tumoral a través de sus moléculas conocidas como marcadores pronóstico son una herramienta prometedora en el tratamiento del CaMa TN. Una de las moléculas con gran potencial en ésta área es la LDH-A, numerosos estudios documentan que su sobreexpresión en cáncer se asocia a un pobre pronóstico (Ward et al., 2012) (Fiume, Manerba, Vettraino, \& Di Stefano, 2010), y se ha demostrado que su inhibición reduce los niveles de ATP e induce apoptosis por medio de la acumulación de ROS en células tumorales de linfoma, riñón, mama, hígado y páncreas (Yang Yang et al., 2014).

En nuestros resultados a nivel de proteína, observamos de manera importante la dramática inhibición de la LDH-A en la línea celular MDA-MB-231 con DoxMetOx, sin embargo con las terapias solas Dox y Ox y la combinación de MetOx no se 
obtuvieron efectos significativos en la disminución de la enzima. Lo anterior sugiere que el efecto no es dependiente del tiempo y probablemente tampoco de la dosis, sino de la sinergia que promueve la Dox al potenciar el efecto de Met y Ox para la promoción de la inhibición de la LDH-A. Por otra parte, DoxMetOx también inhibió de manera importante la expresión de la LDH-A a nivel de mRNA, sugiriendo la inhibición de la transcripción del gen. En este contexto proponemos en primer lugar que aunque Dox no incide sobre la inhibición de la LDH-A si es clave en la potenciación de la sinergia entre Met y Ox, lo que hace que ésta terapia sea efectiva tanto por su especificidad como por su eficacia en tiempos cortos y por otro lado, la combinación de las tres drogas actúan en sinergia provocando una crisis energética en la célula tumoral a consecuencia del bloqueo de la glucólisis aerobia al inhibir simultáneamente a la LDH-A y la vía mTOR, lo cual eventualmente genera la reactivación de la apoptosis junto con el proceso de inducción de autofagia. Lo anterior se sustenta con lo publicado por Fantin y colaboradores en el 2006, quienes con base en diversos ensayos suguieren que la glucólisis y la respiración mitocondrial son procesos estrechamente relacionados, demostrando que la supresión de la producción de lactato incide directamente en la respiración mitocondrial. Ellos observaron que al inhibir la actividad de la LDH-A, el consumo de oxígeno y la actividad de la OXFOS y F16 (un compuesto mitocondrotóxico) se acumuló en los orgánulos; sin embargo, el potencial de membrana mitocondrial disminuyó y la tasa de producción de ATP se redujo, especialmente bajo hipoxia (Fantin, St-Pierre, \& Leder, 2006). Otro grupo de trabajo demostró que la inhibición de la LDH-A por siRNA en células P493 dió como resultado un aumento de ROS y 
del estrés oxidativo, lo que conduce a una mayor necrosis o muerte celular tardía. Sin embargo cuando se añadió el antioxidante N-acetilcisteína (NAC) a las células tratadas con siLDHA, los niveles de ROS y la muerte celular se redujeron significativamente y se observó un rescate parcial de la proliferación celular, posiblemente debido a que los ROS son subproductos naturales de la respiración mitocondrial (Miao et al., 2013). El papel de la LDH-A en la OXFOS está relacionado con la actividad de la fumarato hidratasa (FH). Esta enzima convierte el fumarato en malato y su inhibición puede conducir a una disminución en OXPHOS y un aumento de la glucólisis. En comparación con las células deficientes en FH o de LDH-A, exhiben proliferación disminuida, agotamiento de ATP, aumento de la apoptosis y aumento en el consumo de oxígeno y niveles de ROS. Esto sugiere que la inhibición de la LDH-A en un entorno deficiente en FH puede inducir a las células a aumentar OXFOS. Una posible explicación es que la deficiencia de FH produce una regulación positiva de HIF-1a que induce la expresión de LDHA (Xie et al., 2009) (Ashrafian et al., 2010).

En lo que respecta a los marcadores moleculares de caspasa-3, PARP-1, mTOR, pmTOR, LC3-I y II evaluados, a nivel de proteína con Met observamos una ligera detección de caspasa-3 cleaved, efecto contrario en Dox y Ox donde no se observa detección significactiva de inducción de apoptosis. Sin embargo, con el empleo de MetOx sólo existió una ligera promoción de caspa-3 cleaved. De manera conjunta se detectó PARP-1 cleaved con la exposición a la doble terapia (MetOx). Posiblemente la presencia de Ox en esta combinación no tuvo un papel importante en potenciar el 
mecanismo de acción de Met. Sin embargo, con el empleo de DoxMetOx expuesta a las líneas celulares se observa de manera contundente la detección de dos moléculas importantes en la reparación del daño al DNA y la promoción de apoptosis: PARP-1 y caspasa-3 cleved, respectivamente. Promoviendo en las células la detección de la escición proteolítica de sustratos celulares específicos de la procaspasa en caspasa-3 cleaved que funciona como una de las caspasas ejecutoras en la vía de la apoptosis intrínseca y en cosecuencia la muerte celular. Observamos que el efecto permaneció y se fue intensificando hasta la fase final del experimento, atribuimos lo anterior a la adición de la Dox, que como en los demás ensayos probablemente potenció el efecto de Met y Ox e intensificó la promoción de apoptosis dependiente de caspasas y la reparación del daño al DNA. Con nuestros datos también mostramos que DoxMetOx actúa como agente proapoptótico a través de las vías dependientes de caspasas y PARP-1. Este efecto en la activación de caspasa-3 cleaved se le atribuye a la posible acción de la Met que actúa inhibiendo el complejo I en la mitocondria para inducir apoptosis y reparar daño a DNA a través de PARP-1. La acción de la Met en la triple terapia se sustenta con ensayos realizados en el 2009 por Liu y colaboradores, los cuales demuestran de manera importante a través de WB, ELISA, citometria de flujo y un modelo de xenotransplantes en ratones desnudos, que la Met tiene efectos significativos en 4 lineas celulares de CaMa TN entre ellas MDA-MB-231. Este grupo de trabajo observó tanto in vitro como in vivo la inhibición de la proliferación celular con detención parcial en la fase $S$, apoptosis mediante la activación de las vías de señalización intrínseca (activación de caspasa-3) y extrínseca (activación de 
caspasas 8 y 9). Concluyendo que a nivel molecular la Met aumenta la p-AMPK, reduce p-EGFR, EGFR, p-MAPK, p-Src, ciclina E1 y D1, e induce la escisión proteolítica de PARP-1 en una manera dependiente de la dosis y del tiempo asi como también sustentan que in vivo, Met induce cambios importantes en el metabolismo de la glucosa y los ácidos grasos, que incluyen: mejora en la utilización de glucosa, reducción de la producción de glucosa hepática, aumento de la sensibilidad a la insulina, reducción de la utilización de ácidos grasos libres y modificación del perfil lipídico sérico. En lo que respecta a la detección de PARP-1 en nuestros resultados también se le atribuye al empleo de Met en nuestra combinación farmacológica, los cuales se sustentan con lo reportado por Zhuang y Miskimins. Ellos demostraron que $\mathrm{NAD}^{+}$se requiere como substrato para la generación de los monómeros de ADPribosa. Por lo tanto la sobreactivación de PARP-1 probablemente agota la disponibilidad celular de $\mathrm{NAD}^{+}$e induce un progresivo agotamiento de ATP, lo que conlleva a la activación de la apoptosis debido a la oxidación de la glucosa (Zhuang \& Miskimins, 2011). Otros estudios recientes coinciden en que Met actúa como agente anticancerígeno al inhibir la cadena de transpote de electrones mitocondrial, disminuyendo de manera específica la producción de ATP mitocondrial, lo que conlleva a la muerte de las células tumorales cuando los niveles de ATP glucolíticos disminuyen como resultado de la limitada disponibilidad de glucosa. Asi como también inducir la muerte célular por inhibición de la capacidad biosintética de las mitocondrias para generar macromoléculas tales como lípidos, aminoácidos y nucleótidos (DeBerardinis \& Chandel, 2016). Otro efecto atribuible a Dox es su probable efecto dual al promover apoptosis y autofagia o viceversa. Éste efecto se 
observa en nuestros resultados a nivel de proteína con la triple terapia, que en los mismos tiempo se detectó caspasa-3 cleaved, PARP-1 cleaved, inactivación de pmTOR e hiperlipidación de LC3-II. Lo anterior se sustenta con lo reportado por Gross y Katz, quienes de manera importante revelaron que tanto la apoptosis como la autofagia comparten reguladores moleculares comunes, como lo son el complejo Beclina-1/Bcl-2 que resultaron ser un objetivo potencial para la autofagia inducida por Dox. Este grupo de trabajo en estudios con fibroblastos embrionarios de ratón (MEF) doble knockout $\left(\mathrm{Bax}^{-1-} \mathrm{Bak}^{-1-}\right.$ ) demostró resistencia a un rango de inductores de apoptosis. De manera importante, cuando se trataron con fármacos que dañan el ADN similares a Dox, los MEF $\left(\mathrm{Bax}^{-1-} \mathrm{Bak}^{-1-}\right)$ no lograron apoptosis y en su lugar dieron lugar a una autofagia considerable; con esto se sustenta la teoría de que la supresión de la apoptosis provoca autofagia y viceversa (Gross \& Katz, 2017). Sin embargo sugerimos que la promoción de apoptosis y la inhibición de la LDH-A observadas en nuestros resultados se le atribuyen en mayor grado a Met, la cual es considerada un inhibidor general de crecimiento mediante la activación de la AMP cinasa y la inactivación de mTOR y la disminución de la S6K (Libby et al., 2009) en las líneas celulares de CaMa TN.

En cuanto a los marcadores para glucólisis y autofagia (mTOR y LC3-I yll, respectivamente), a nivel de proteína observamos que con las terapias solas: Dox, Met, Ox y con la terapia coadyuvante MetOx no hubo promoción significativa en la inhibición de glucólisis ni de autofagia en ninguno de los tiempos experimentales. A pesar de que se sabe que Met y Ox participan en la inducción de ambos 
mecanismos, en nuestros resultados obtenidos con la línea celular MDA-MB-231 no se observó este efecto. Posiblemente la discrepancia con nuestros resultados en cuanto al efecto de las terapias solas y en duplets sugieren que tanto la inhibición de la LDH-A como la activación de la fosforilación de mTOR ya sea por Dox, Met y Ox pueden variar según el tipo celular y que por lo tanto su uso de éste modo (adyuvante o en monoterapia) no es generalizado para todas las células tumorales adyacentes (Arora et al., 2015) (Gibson, 2010). Sin embargo, la combinación de DoxMetOx a partir de las 4 horas de exposición a la terapia se incrementó el efecto autofágico medido por la degradación de la proteína LC3-I a LC3-II, marcador molecular contundente en la promoción de autofagia a través de la inhibición de la fosforilación de mTOR y la glucólisis. Éste fenómeno fue observado de manera permanente hasta la fase final de los experimentos. Cabe mencionar que de manera importante este patrón de inducción de LC3-II y de p-mTOR no solo se repitió a nivel de proteína, sino que también se observaron en los ensayos de TEM y GFP-LC3-II con el mismo fenotipo MDA-MB-231. La consistencia en la repetición de este patrón de inducción de autofagia en todos nuestros ensayos probablemente se debió a que DoxMetOx indujo la inhibición de mTOR y generó la depleción de todo el sistema metabolico de la célula, teniendo como consecuencia la inhibición de la síntesis de biomoleculas y el bloqueo de la LDH-A. Nuestros resultados son sustentados con una reciente publicación que demostró que en la línea celular de cáncer de pulmón A549 en presencia de Ox induce autofagia, observando la degradación de la proteína LC3, además de la inhibición de la vía Akt-mTOR (Yang Yang et al., 2014). En otro trabajo se reportó que debido el efecto sinérgico entre la combinación de Ox y la 
Fenformina se inhibe la proliferación de células cancerosas de mama, melanoma, colon, pulmón y próstata e in vivo reduce considerablemente el tamaño del tumor después de 21 días de tratamiento (Miskimins et al., 2014). Los autores sugieren que el éxito de esta combinación farmacológica se debe a que la Fenformina aumenta la apoptosis a través de la inhibición del complejo I en la mitocondria y simultáneamente, el Ox inside sobre la enzima LDH-A en el citosol. Sin embargo, a pesar de la similitud en la estructura química de la Met y la Fenformina, en nuestro trabajo previo, la combinación entre Met y $\mathrm{Ox}$ in vivo e in vitro no incide en la reducción del crecimiento del tumor, sólo se produce efecto favorable en presencia de los dos fármacos con la Dox. Sin dejar de lado la alta citotoxicidad que genera Dox, diversos estudios sustentan que independientemente del blanco terapéutico el efecto de Dox en combinación es más favorable que si se emplea de manera adyuvante; por ejemplo, Nath y colaboradores observaron que la lonidamina, un inhibidor de la HK2 en ensayos preclínicos y clínicos demostró que en combinación con Dox tiene una mejor eficacia terapéutica para el tratamiento de tumores de mama, próstata, melanoma, cerebro y ovario. Sin embargo durante el proceso de tratamiento, se observó alta toxicidad hepática relacionada con el empleo de ésta combinación (Nath et al., 2015). Con lo anterior podemos sustentar que probablemnte el mecanismo efector de Dox en esta combinación es potenciar el efecto de Met y Ox, que probablemente no inside sobre su blanco terapéutico, sino que se encuentra intensificando el efecto de los fármacos con los que se combine y su citotoxicidad posiblemente se vea atenuada por la Met. La baja citotoxicidad de Met se sustenta con lo reportado por Schaeffeler \& Schwab en el 2013, quienes 
sugieren que el notable perfil de seguridad de la metformina se debe a su absorción por transportadores de cationes orgánicos (OCT), que están presentes en órganos como el hígado y el riñón. Ciertas células tumorales también expresan OCT para permitir la absorción de metformina (Pollak, 2014) (Chandel et al., 2016).

En nuestros resultados de análisis de inducción de autofagia a través de la formación de autofagolisosomas empleando la TEM, sustentamos la promoción de este evento con el empleo de DoxMetOx. En las líneas celulares tratadas con la triple terapia se observó el envolvimiento de diversos orgánulos, entre ellos mitocondrias, en estructura de doble membrana (autofagolisosomas), este evento permaneció y se intensificó hasta la fase final del experimento. Es importante mencionar que la formación de los autofagolisosomas fue un patrón que se repitió no sólo en el fenotipo MDA-MB-231 sino también en MDA-MB-468 y BT-20. Sin embargo, con la terapia de primera línea, Dox, se observan dos eventos importantes; el primero que de ninguna manera favorece la autofagia y la segunda que debido a su alta citotoxicidad promueve de imediato, significativo daño celular masivo. Se observa ruptura de membranas y disociación de organelos en el citoplasma, lo que podria referir un tipo de muerte celular por necrosis. Para sustentar lo obtenido en las TEM, finalmente realizamos otro ensayo contundente de promociónn de autofagia: GFPLC3 en las líneas celulares de CaMa MDA-MB-231, MDA-MB-468 y BT-20. De manera importante se repitió el mismo evento con el empleo de MetOxDox, favoreciendo la inducción de la autofagia al detectar mayor número de áreas punteadas de LC3-II en las tres líneas celulares. Mientras que con el empleo de la 
terapia de primera línea, la Dox nuevamente se observa daño celular masivo debido a su alta citotoxicidad.

En nuestros resultados de TEM y GFP-LC3 con el empleo de DoxMetOx se observa la condundente inducción de autofagia, esto se puede sustentar con lo reportado por Keulers y colaboradores quienes observaron que debido a largos periodos de estrés por deprivación de nutrientes se promueve en las células tumorlales la eliminación selectiva de mitocondrias dañadas, las cuales reducen la carga de especies reactivas de oxígeno (ROS), homeostasis metabólica y degradación de proteínas sobreexpresadas (Keulers, Schaaf, \& Rouschop, 2016). La inducción de éste mecanismo como herrameinta terapéutica en el tratamiento del cáncer es controversial, debido a que existen diversos estudios que han implicado a la autofagia en la sobrevivencia y la progresión del tumor; de manera contraria, la sobreregulación de la autofagia e incluso la dependencia de la misma es característica de diversas malignidades (Qu et al., 2003). En cáncer de mama, próstata, hígado, colon y otros; se ha observado que la autofagia puede permitir a las células cancerosas sobrevivir al estrés metabólico y la hipoxia, evadir el sistema inmune, promover invasión y metastásis, secretar proteínas remodeladoras de la TME entre otras caracerististicas. Lo anterior representa el lado contrario de otra respuesta al estrés por deprivación de nutrientes. Lo que hace que la autofagia sea parte del proceso de promoción de la tumorigénesis, haciéndola responsable de la sobrevivencia del tumor (Mowers, Sharifi, \& Macleod, 2017). 
Nuevamente el efecto de la triple terapia suguiere la presencia de dos mecanismos de suma importancia y nos muestra que ambos están ocurriendo de manera conjunta, aunque sin poder determinar cual de los dos eventos sucede primero. Otra observación importante que suguieren estos resultados a la par de los ensayos funcionales de WB es que ésta terapia es capaz de inducir la reprogramación de la célula tumoral, al inhibir su crecimiento y proliferación de manera especifica sobre la vía mTOR y la glucólisis aerobia, importantes vías de generación de energética.

En todos nuestros ensayos in vitro con las terapias solas o en duplets podríamos inferir que las líneas celulares evadieron la apoptosis al presentar cierta resistencia a los fármacos (solos o coadyuvantes) induciendo el bloqueo de diversos estimulos proapototicos y la consecuente inhibición de la apoptosis. Los resultados mostraron que los estimulos que desencadenaron estas terapias la expresión de genes antiapoptóticos y de manera conjunta la disminución de la expresión de genes proapoptóticos (Vander Heiden, Cantley, \& Thompson, 2009), conduciendo a las células a escapar de la apoptosis. Con base en lo anterior podríamos inferir que la promoción del descontrolado crecimiento tumoral en nuestro modelo in vivo se debió a la resistencia ocasionada por las modificaciones antes mencionadas que los fármacos promovieron en los tumores.

De acuerdo con nuestros resultados, encontramos que DoxMetOx participa en el proceso de inducción de autofagia a través de la acumulación de LC3-II y de la inhibición de mTOR. A pesar de lo anterior se sabe que la promoción de la autofagia 
puede actuar como protumorigénico en los procesos de invasión y metástasis (Gump \& Thorburn, 2011) (Tschan \& Simon, 2010) o bien como supresor de tumor en etapas tempranas a través de la proteína Beclina-1; además las proteínas autofágicas específicas podrían regular la apoptosis a través de mecanismos no relacionados con su función canónica en la autofagia a través de Bcl-2 (Macintosh \& Ryan, 2013).

La capacidad de medir objetivamente la muerte celular a través de ensayos funcionales es esencial para comprender e investigar las causas y los tratamientos del cancer, donde la participación de la apoptosis o la autofagia puedan tener implicaciones en la progresión y el tratamiento de la enfermedad; por ejemplo, en las células tumorales donde la autofagia está bloqueada, la síntesis de proteínas predominará sobre la degradación de las proteínas induciendo la progresión del tumor. En etapas avanzadas del tumor la autofagia ejerce una función de prosupervivencia que es necesaria para proporcionar nutrientes esenciales a las células tumorales que no pueden acceder a la corriente sanguínea y es entonces que en estos casos la supresión de la autofagia inhibiría la progresión tumoral (Shen, Kepp, \& Kroemer, 2012).

Es importante mencionar que la efectividad de la combinación de DoxMetOx es superior a lo que ya existe en la fase clínica, pues de manera importante se pensaba que sólo la inhibición de mTOR funcionaba como un blanco terapéutico efectivo contra cualquier tipo de cáncer. Sin embargo el papel de la rapamicina, un fármaco inmunosupresor aprobado por la FDA y sus análogos sirolimus, temsirolimus y 
everolimus como inhibidores de mTORC1 se limitan a la actividad de éste complejo con minimo efecto sobre la la actividad de mTORC2. En estudios preclínicos, se informó que la rapamicina y sus análogos tienen actividad antiproliferativa en varios tipos de cáncer y ahora están siendo probados en la clínica para el tratamiento del linfoma y los cánceres neuroendocrino, endometrial y de mama; sin embargo existen diversos estudios clínicos e in vitro, que han demostrado que el efecto de éstos inhibidores sólo ralentizan la glucólisis a través de la señalización de Akt/mTORC1 pero no la inhiben por completo, lo que deja en duda su efectividad al observar la recurrencia de la enfermedad asi como la proliferación en células de mama y próstata respectivamente (G.-Q. Chen et al., 2015). El efecto contrario se promueve con DoxMetOx, al inhibir la glucólisis y la LDH-A a través de la activación de mTOR, sin recurrencia de la enfermadad post-tratamiento en nuestros ensayos in vivo. Además ésta terapia de combinación puede superar la resistencia a los medicamentos, tiene efectos antioxidantes y puede proporcionar un enfoque novedoso para el tratamiento del cáncer. Por ejemplo, la inhibición de la glucólisis combinada con fármacos que dañan el ADN o agentes quimioterapéuticos pueden ser estrategias anticancerígenas eficaces al debilitar la capacidad de reparación del daño celular y mejorar la citotoxicidad del fármaco.

Sin duda hacen falta más experimentos que nos lleven a elucidar sobre qué mecanismo desencadena el otro para que, como lo demuestran nuestros resultados, se expresen marcadores de apoptosis y autofagia simultáneamente. 
Actualmente existen pocos estudios publicados a cerca del empleo de ésta novedosa terapia, sin embargo, lo que se sabe hasta el momento con base en los estudios realizados en nuestro grupo de trabajo, sustenta la efectividad del empleo de DoxMetOx en diversos tipos de cáncer como el de mama (García-Castillo et al., 2017), colon (Figueroa-González et al., 2016) y cérvix (paper en preparación). Lo anterior muestra evidencia de que la depleción de marcadores moleculares clave del metabolismo de la célula tumoral como la LDH-A y mTOR y la síntesis de ácidos nucléicos podrían llegar a ser una herramienta terapéutica clave en el tratamiento no sólo del CaMa sino hasta el momento también de colon y cérvix.

Aunque la participación de la autofagia y la apoptosis en cáncer aún es parte de un importante debate entre diversos grupos de trabajo; en el nuestro es necesario continuar con múltiples estratégias experimentales in vitro e in vivo para seguir sustentando lo hasta ahora reportado y sobre todo para elucidar de manera más precisa el mecanismo de acción a nivel molecular de DoxMetOx, que promueve la reprogramación del metabolismo de la célula tumoral activando éstos dos mecanismos de muerte celular, los cuales en éste trabajo jugan un papel importante como mecanismos de defensa anti-tumorogénicos. 


\section{CONCLUSIONES}

Con base en nuestros resultados concluimos que:

1. El mecanismo de acción de la combinación de metformina y oxamato en el cáncer de mama triple negativo, indican que el oxamato de sodio incide específicamente sobre la inhibición de la LDHA, lo que resulta en un aumento de la fosforilación oxidativa.

2. El aumento en el estrés oxidativo ocasionado por la disminución de la LDH-A promueve retraso del crecimiento y la consiguiente inhibición de la glucólisis.

3. La metformina induce la activación de LKB1 y la fosforilación de AMPK, lo que induce la inactivación de mTORC1 y de las vías biosintéticas posteriores, como la biogénesis de ARNm, la biogénesis de ribosomas y la síntesis de lípidos.

4. El empleo de ésta teapia conduce drásticamente a la activación concurrente de la apoptosis, principalmente a la activación de la autofagia y al agotamiento de la energía Lo que conduece inevitablemente a la muerte de la célula tumoral. De manera importante, nuestros resultados muestran el mismo patrón de comportamiento no solo en líneas celulares de CaMa: MDA-MB-231 MDAMB-213, BT-20 sino que también en cáncer de colon y cérvix. Lo que la hace 
una terapia prometerdora, específica y efectiva no solo para el fenotipo de mama TN, sino también para otros tipos de cáncer.

5. Representación gráfica del probable mecanismo de acción que promueve la triple terapia en la linea cellular de CaMa (Figura 24).

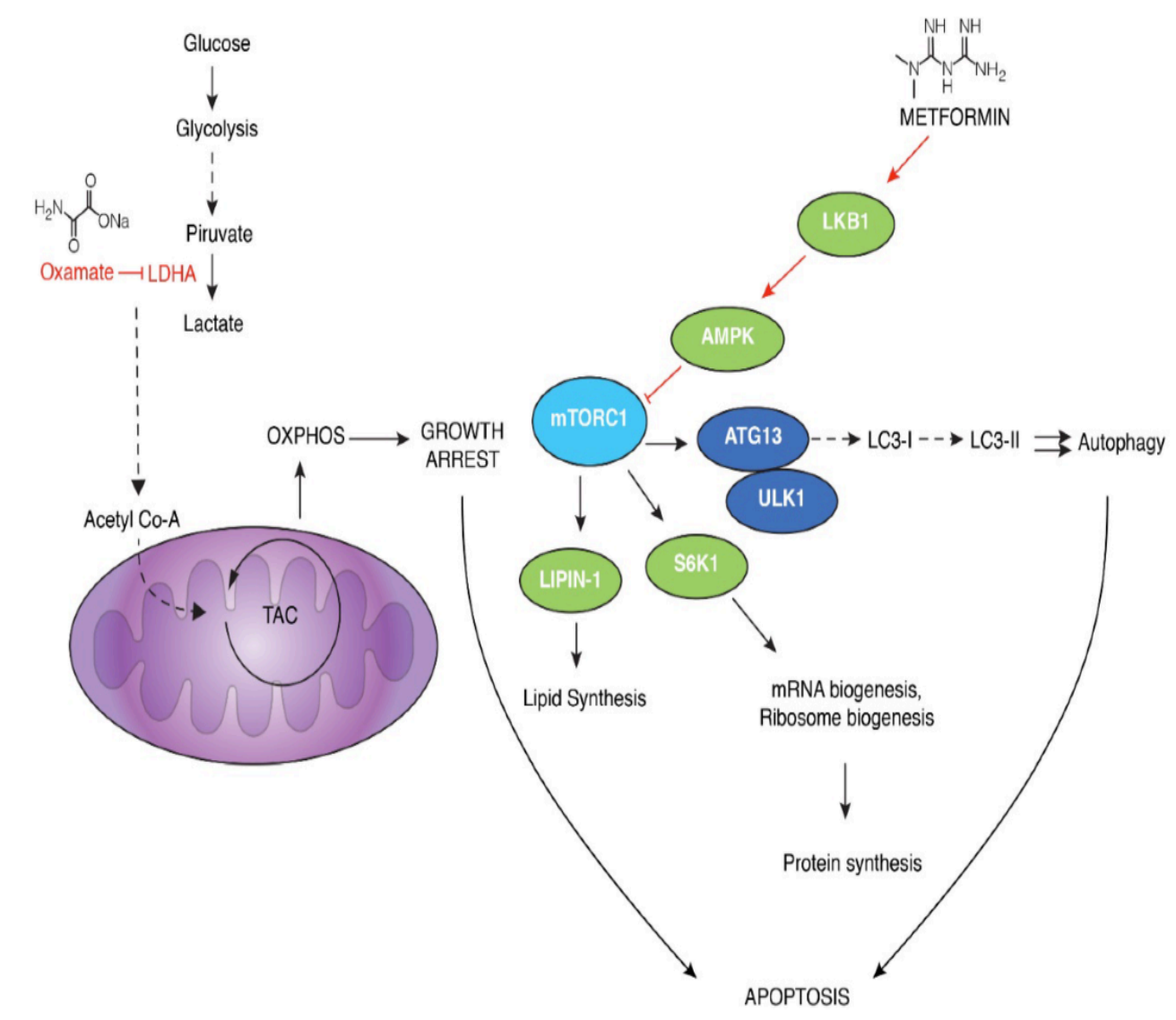

Figura 24. Papel que juega el mecanismo de acción de la terapia sobre la insidencia de blancos moleculares (GarcíaCastillo et al., 2017). 


\section{BIBLIOGRAFÍA}

Akar, U., Chaves-Reyez, A., Barria, M., Tari, A., Sanguino, A., Kondo, Y.,Ozpolat, B. (2008). Silencing of Bcl-2 expression by small interfering RNA induces autophagic cell death in MCF-7 breast cancer cells. Autophagy, 4(5), 669-679. https://doi.org/10.4161/auto.6083.

Akshata Desai, K. A. (2013). Triple Negative Breast Cancer - An Overview. Hereditary Genetics, 10-12. https://doi.org/10.4172/2161-1041.S2-001.

Alberobello, A. T., D'Esposito, V., Marasco, D., Doti, N., Ruvo, M., Bianco, R.,Formisano, P. (2010). Selective disruption of insulin-like growth factor-1 (IGF1) signaling via phosphoinositide-dependent kinase-1 prevents the protective effect of IGF-1 on human cancer cell death. Journal of Biological Chemistry, 285(9), 6563-6572. https://doi.org/10.1074/jbc.M109.097410.

Albert, S., Serova, M., Dreyer, C., Sablin, M.-P., Faivre, S., \& Raymond, E. (2010). New inhibitors of the mammalian target of rapamycin signaling pathway for cancer. Expert Opinion on Investigational Drugs, 19(8), 919-930. https://doi.org/10.1517/13543784.2010.499121.

Alcalá-Corona, S. A., de Anda-Jáuregui, G., Espinal-Enríquez, J., \& HernándezLemus, E. (2017). Network modularity in breast cancer molecular subtypes. Frontiers in Physiology, 8(NOV). https://doi.org/10.3389/fphys.2017.00915.

An, J., Zhang, Y., He, J., Zang, Z., Zhou, Z., Pei, X.,Li, S. (2017). Lactate dehydrogenase $A$ promotes the invasion and proliferation of pituitary adenoma. Scientific Reports, 7(1). https://doi.org/10.1038/s41598-017-04366-5.

Anand, P., Kunnumakara, A. B., Sundaram, C., Harikumar, K. B., Tharakan, S. T., Lai, O. S., ... Aggarwal, B. B. (2008). Cancer is a preventable disease that requires major lifestyle changes. Pharmaceutical Research. https://doi.org/10.1007/s11095-008-9661-9.

Anders, C. K., \& Carey, L. A. (2009). Biology, metastatic patterns, and treatment of patients with triple-negative breast cancer. Clinical Breast Cancer. https://doi.org/10.3816/CBC.2009.s.008.

Arora, R., Schmitt, D., Karanam, B., Tan, M., Yates, C., \& Dean-Colomb, W. (2015). Inhibition of the Warburg effect with a natural compound reveals a novel measurement for determining the metastatic potential of breast cancers. Oncotarget, 6(2), 662-678. https://doi.org/10.18632/oncotarget.2689

Ashkenazi, A. (2008). Targeting the extrinsic apoptosis pathway in cancer. Cytokine and Growth Factor Reviews, 19(3-4), 325-331. https://doi.org/10.1016/j.cytogfr.2008.04.001

Ashley, N., \& Poulton, J. (2009). Mitochondrial DNA is a direct target of anti-cancer anthracycline drugs. Biochemical and Biophysical Research Communications, 378(3), 450-455. https://doi.org/10.1016/j.bbrc.2008.11.059

Ashrafian, H., O'Flaherty, L., Adam, J., Steeples, V., Chung, Y. L., East, P., Pollard, P. J. (2010). Expression profiling in progressive stages of fumarate-hydratase deficiency: The contribution of metabolic changes to tumorigenesis. Cancer Research, 70(22), 9153-9165. https://doi.org/10.1158/0008-5472.CAN-10-1949 
Badve, S., Dabbs, D. J., Schnitt, S. J., Baehner, F. L., Decker, T., Eusebi, V., ReisFilho, J. S. (2011). Basal-like and triple-negative breast cancers: A critical review with an emphasis on the implications for pathologists and oncologists. Modern Pathology. https://doi.org/10.1038/modpathol.2010.200.

Bartkova, J., Hořejší, Z., Koed, K., Krämer, A., Tort, F., Zleger, K., Bartek, J. (2005). DNA damage response as a candidate anti-cancer barrier in early human tumorigenesis. Nature, 434(7035), 864-870. https://doi.org/10.1038/nature03482.

Baselga, J., Gómez, P., Greil, R., Braga, S., Climent, M. A., Wardley, A. M., Awada, A. (2013). Randomized phase II study of the anti-epidermal growth factor receptor monoclonal antibody cetuximab with cisplatin versus cisplatin alone in patients with metastatic triple-negative breast cancer. Journal of Clinical Oncology: Official Journal of the American Society of Clinical Oncology, 31(20), 2586-2592. https://doi.org/10.1200/JCO.2012.46.2408.

Basho, R. K., Gilcrease, M., Murthy, R. K., Helgason, T., Karp, D. D., MericBernstam, F., Moulder, S. L. (2017). Targeting the PI3K/AKT/mTOR pathway for the treatment of mesenchymal triple-negative breast cancer: Evidence from a phase 1 trial of mTOR inhibition in combination with liposomal doxorubicin and bevacizumab. JAMA Oncology, 3(4), 509-515. https://doi.org/10.1001/jamaoncol.2016.5281.

Beasley, J. M., Coronado, G. D., Livaudais, J., Angeles-Llerenas, A., Ortega-Olvera, C., Romieu, I.,Torres-Mejía, G. (2010). Alcohol and risk of breast cancer in Mexican women. Cancer Causes \& Control: CCC, 21(6), 863-70. https://doi.org/10.1007/s10552-010-9513-x.

Bensinger, S. J., \& Christofk, H. R. (2012). New aspects of the Warburg effect in cancer cell biology. Seminars in Cell \& Developmental Biology, 23(4), 352-361. https://doi.org/10.1016/j.semcdb.2012.02.003

Bernier J, P. P. (2016). Surgery and radiation therapy of triple-negative breast cancers: From biology to clinics. Breast., 28, 148-155. https://doi.org/10.1016/j.breast.2016.05.014

Bhutia, S. K., Dash, R., Das, S. K., Azab, B., Su, Z. Z., Lee, S. G., Fisher, P. B. (2010). Mechanism of autophagy to apoptosis switch triggered in prostate cancer cells by antitumor cytokine melanoma differentiation-associated gene 7/interleukin-24. Cancer Research, 70(9), 3667-3676. https://doi.org/10.1158/0008-5472.CAN-09-3647.

Bhutia, S. K., Kegelman, T. P., Das, S. K., Azab, B., Su, Z. -z., Lee, S.-G., Fisher, P. B. (2010). Astrocyte elevated gene-1 induces protective autophagy. Proceedings of the National Academy of Sciences, 107(51), 22243-22248. https://doi.org/10.1073/pnas.1009479107.

Bhutia, S. K., Mukhopadhyay, S., Sinha, N., Das, D. N., Panda, P. K., Patra, S. K., Fisher, P. B. (2013). Autophagy: Cancer's friend or foe? Advances in Cancer Research, 118, 61-95. https://doi.org/10.1016/B978-0-12-407173-5.00003-0.

Blagosklonny, M. V. (2010). Calorie restriction: Decelerating mTOR-driven aging from cells to organisms (including humans). Cell Cycle. https://doi.org/10.4161/cc.9.4.10766. 
Blagosklonny, M. V., \& Hall, M. N. (2009). Growth and aging: a common molecular mechanism. Aging. https://doi.org/10.18632/aging.100040.

Bodmer, M., Meier, C., Krahenbuhl, S., Jick, S. S., \& Meier, C. R. (2010). Long-term metformin use is associated with decreased risk of breast cancer. Diabetes Care, 33(6), 1304-1308. https://doi.org/10.2337/dc09-1791.

Brand, K. (1985). Glutamine and glucose metabolism during thymocyte proliferation. Pathways of glutamine and glutamate metabolism. Biochemical Journal, 228(2), 353-361. https://doi.org/10.1042/bj2280353.

Campisi, J. (2013). Aging, Cellular Senescence, and Cancer. Annual Review of Physiology, 75(1), 685-705. https://doi.org/10.1146/annurev-physiol-030212183653.

Cárdenas Sánchez, J., Sandoval Guerrero, F., Alatriste Martínez, S., Alvarado Cabrero, I., Barroso Bravo, S., Bargallo Rocha, J. E., Villaseñor Navarro, Y. (2010). Tercera revisión del Consenso Nacional sobre Diagnóstico y Tratamiento del Cáncer Mamario (Tercera de tres partes). In Ginecologia y Obstetricia de Mexico (Vol. 78, pp. 199-212).

Cardoso, S., Santos, R. X., Carvalho, C., Correia, S., Pereira, G. C., Pereira, S. S., Moreira, P. I. (2008). Doxorubicin increases the susceptibility of brain mitochondria to $\mathrm{Ca} 2+-$ induced permeability transition and oxidative damage. Free Radical Biology and Medicine, 45(10), 1395-1402. https://doi.org/10.1016/j.freeradbiomed.2008.08.008.

Carmeliet, P., \& Jain, R. K. (2011). Molecular mechanisms and clinical applications of angiogenesis. Nature. https://doi.org/10.1038/nature10144.

Chandel, N. S., Avizonis, D., Reczek, C. R., Weinberg, S. E., Menz, S., Neuhaus, R., ... Pollak, M. (2016). Are Metformin Doses Used in Murine Cancer Models Clinically Relevant? Cell Metabolism. https://doi.org/10.1016/j.cmet.2016.03.010.

Chavarri-Guerra, Y., St Louis, J., Liedke, P. E. R., Symecko, H., Villarreal-Garza, C., Mohar, A., Goss, P. E. (2014). Access to care issues adversely affect breast cancer patients in Mexico: Oncologists perspective. BMC Cancer, 14(1), 1-8. https://doi.org/10.1186/1471-2407-14-658.

Chávarri-Guerra, Y., Villarreal-Garza, C., Liedke, P. E. R., Knaul, F., Mohar, A., Finkelstein, D. M., \& Goss, P. E. (2012). Breast cancer in Mexico: A growing challenge to health and the health system. The Lancet Oncology, 13(8), e335e343. https://doi.org/10.1016/S1470-2045(12)70246-2.

Chen, G.-Q., Tang, C.-F., Shi, X.-K., Lin, C.-Y., Fatima, S., Pan, X.-H., Bian, Z.-X. (2015). Halofuginone inhibits colorectal cancer growth through suppression of Akt/mTORC1 signaling and glucose metabolism. Oncotarget, 6(27), 24148-62. https://doi.org/10.18632/oncotarget.4376.

Chen, M.-B., Wu, X.-Y., Gu, J.-H., Guo, Q.-T., Shen, W.-X., \& Lu, P.-H. (2011). Activation of AMP-activated protein kinase contributes to doxorubicin-induced cell death and apoptosis in cultured myocardial H9c2 cells. Cell Biochemistry and Biophysics, 60(3), 311-22. https://doi.org/10.1007/s12013-011-9153-0.

Cheng, Y., Ren, X., Hait, W. N., \& Yang, J.-M. (2013). Therapeutic Targeting of Autophagy in Disease: Biology and Pharmacology. Pharmacological Reviews, 65(4), 1162-1197. https://doi.org/10.1124/pr.112.007120. 
Chipuk, J. E., Moldoveanu, T., Llambi, F., Parsons, M. J., \& Green, D. R. (2010). The BCL-2 Family Reunion. Molecular Cell. https://doi.org/10.1016/j.molcel.2010.01.025.

Chowdhury, I., Tharakan, B., \& Bhat, G. K. (2008). Caspases - An update. Comparative Biochemistry and Physiology - B Biochemistry and Molecular Biology. https://doi.org/10.1016/j.cbpb.2008.05.010.

Cleland, M. M., Norris, K. L., Karbowski, M., Wang, C., Suen, D. F., Jiao, S., Youle, R. J. (2011). Bcl-2 family interaction with the mitochondrial morphogenesis machinery. Cell Death and Differentiation, 18(2), 235-247. https://doi.org/10.1038/cdd.2010.89.

Clem, B. F., O’Neal, J., Tapolsky, G., Clem, A. L., Imbert-Fernandez, Y., Kerr, D. A., ... Chesney, J. (2013). Targeting 6-Phosphofructo-2-Kinase (PFKFB3) as a Therapeutic Strategy against Cancer. Molecular Cancer Therapeutics, 12(8), 1461-1470. https://doi.org/10.1158/1535-7163.MCT-13-0097.

Colombi, M., Molle, K. D., Benjamin, D., Rattenbacher-Kiser, K., Schaefer, C., Betz, C., Moroni, C. (2011). Genome-wide shRNA screen reveals increased mitochondrial dependence upon mTORC2 addiction. Oncogene, 30(13), 15511565. https://doi.org/10.1038/onc.2010.539.

Cotter, T. G. (2009). Apoptosis and cancer: The genesis of a research field. Nature Reviews Cancer. https://doi.org/10.1038/nrc2663.

Creighton, C. J. (2012). The molecular profile of luminal B breast cancer. Biologics: Targets and Therapy, 6, 289-297. https://doi.org/10.2147/BTT.S29923.

Curtis, C., Shah, S. P., Chin, S., Turashvili, G., Rueda, O. M., Dunning, M. J., Purushotham, A. (2012). The genomic and transcriptomic architecture of 2,000 breast tumours reveals novel subgroups. https://doi.org/10.1038/nature10983.

Dallaglio, K., Bruno, A., Cantelmo, A. R., Esposito, A. I., Ruggiero, L., Orecchioni, S., ... Albini, A. (2014). Paradoxic effects of metformin on endothelial cells and angiogenesis. Carcinogenesis, 35(5), 1055-1066. https://doi.org/10.1093/carcin/bgu001.

Dazert, E., \& Hall, M. N. (2011). MTOR signaling in disease. Current Opinion in Cell Biology, 23(6), 744-755. https://doi.org/10.1016/j.ceb.2011.09.003.

DeBerardinis, R. J., \& Chandel, N. S. (2016). Fundamentals of cancer metabolism. Science Advances, 2(5), e1600200-e1600200. https://doi.org/10.1126/sciadv.1600200.

Decuypere, J.-P., Parys, J. B., \& Bultynck, G. (2012). Regulation of the Autophagic Bcl-2/Beclin 1 Interaction. Cells, 1(4), 284-312. https://doi.org/10.3390/cells1030284.

Denko, N. C. (2008). Hypoxia, HIF1 and glucose metabolism in the solid tumour. Nature Reviews Cancer. https://doi.org/10.1038/nrc2468.

Dent, R., Trudeau, M., Pritchard, K. I., Hanna, W. M., Kahn, H. K., Sawka, C. A., Narod, S. A. (2007). Triple-negative breast cancer: Clinical features and patterns of recurrence. Clinical Cancer Research. https://doi.org/10.1158/10780432.CCR-06-3045.

DeSantis, C. E., Fedewa, S. A., Goding Sauer, A., Kramer, J. L., Smith, R. A., \& Jemal, A. (2016). Breast Cancer Statistics, 2015: Convergence of Incidence 
Rates Between Black and White Women. CA Cancer J Clin, 66, 31-42. https://doi.org/10.3322/caac.21320.

Dewar, R., Fadare, O., Gilmore, H., \& Gown, A. M. (2011). Best practices in diagnostic immunohistochemistry: Myoepithelial markers in breast pathology. Archives of Pathology and Laboratory Medicine. https://doi.org/10.1043/20100336-CP.1.

Dick, F. A., \& Rubin, S. M. (2013). Molecular mechanisms underlying RB protein function. Nature Reviews Molecular Cell Biology. https://doi.org/10.1038/nrm3567.

Duffy, M. J., McGowan, P. M., \& Crown, J. (2012). Targeted therapy for triplenegative breast cancer: Where are we? International Journal of Cancer, 131(11), 2471-2477. https://doi.org/10.1002/ijc.27632.

Düvel, K., Yecies, J. L., Menon, S., Raman, P., Lipovsky, A. I., Souza, A. L., Manning, B. D. (2010). Activation of a metabolic gene regulatory network downstream of mTOR complex 1. Molecular Cell, 39(2), 171-183. https://doi.org/10.1016/j.molcel.2010.06.022.

Eisenberg-Lerner, A., Bialik, S., Simon, H. U., \& Kimchi, A. (2009). Life and death partners: Apoptosis, autophagy and the cross-talk between them. Cell Death and Differentiation. https://doi.org/10.1038/cdd.2009.33.

Ellis, H., \& Mahadevan, V. (2013). Anatomy and physiology of the breast. Surgery Oxford International Edition, 31(1), 11-14. https://doi.org/10.1016/j.mpsur.2012.10.018.

Eom, Y. W., Kim, M. A., Park, S. S., Goo, M. J., Kwon, H. J., Sohn, S., Choi, K. S. (2005). Two distinct modes of cell death induced by doxorubicin: Apoptosis and cell death through mitotic catastrophe accompanied by senescence-like phenotype. Oncogene, 24(30), 4765-4777. https://doi.org/10.1038/sj.onc.1208627.

Ersoy, C., Kiyici, S., Budak, F., Oral, B., Guclu, M., Duran, C., ... Imamoglu, S. (2008). The effect of metformin treatment on VEGF and PAI-1 levels in obese type 2 diabetic patients. Diabetes Research and Clinical Practice, 81(1), 56-60. https://doi.org/10.1016/j.diabres.2008.02.006.

Facchinetti, V., Ouyang, W., Wei, H., Soto, N., Lazorchak, A., Gould, C., Jacinto, E. (2008). The mammalian target of rapamycin complex 2 controls folding and stability of Akt and protein kinase C. The EMBO Journal, 27(14), 1932-43. https://doi.org/10.1038/emboj.2008.120.

Fahlén, M., Fornander, T., Johansson, H., Johansson, U., Rutqvist, L. E., Wilking, N., \& Von Schoultz, E. (2013). Hormone replacement therapy after breast cancer: 10 year follow up of the Stockholm randomised trial. European Journal of Cancer, 49(1), 52-59. https://doi.org/10.1016/j.ejca.2012.07.003.

Fantin, V. R., St-Pierre, J., \& Leder, P. (2006). Attenuation of LDH-A expression uncovers a link between glycolysis, mitochondrial physiology, and tumor maintenance. Cancer Cell, 9(6), 425-434. https://doi.org/10.1016/j.ccr.2006.04.023.

Farshid, G. (2014). The Normal Breast and Risk Factors for Breast Cancer A2 McManus, Linda M. In R. N. Mitchell (Ed.), Pathobiology of Human Disease (pp. 
899-919). San Diego: Academic Press.

Faubert, B., Vincent, E. E., Poffenberger, M. C., \& Jones, R. G. (2015). The AMPactivated protein kinase (AMPK) and cancer: Many faces of a metabolic regulator. Cancer Letters. https://doi.org/10.1016/j.canlet.2014.01.018

Ferlay, J., Shin, H. R., Bray, F., Forman, D., Mathers, C., \& Parkin, D. M. (2010). Estimates of worldwide burden of cancer in 2008: GLOBOCAN 2008. International Journal of Cancer, 127(12), 2893-2917. https://doi.org/10.1002/ijc.25516.

Ferlay, J., Soerjomataram, I., Dikshit, R., Eser, S., Mathers, C., Rebelo, M., ... Bray, F. (2015). Cancer incidence and mortality worldwide: Sources, methods and major patterns in GLOBOCAN 2012. International Journal of Cancer, 136(5), E359-E386. https://doi.org/10.1002/ijc.29210.

Ferrara, N., Gerber, H. P., \& LeCouter, J. (2003). The biology of VEGF and its receptors. Nature Medicine. https://doi.org/10.1038/nm0603-669

Figueroa-González, G., García-Castillo, V., Coronel-Hernández, J., López-Urrutia, E., León-Cabrera, S., Arias-Romero, L. E., Pérez-Plasencia, C. (2016). Antiinflammatory and Antitumor Activity of a Triple Therapy for a Colitis-Related Colorectal Cancer. Journal of Cancer, 7(712). https://doi.org/10.7150/jca.13123

Fiume, L., Manerba, M., Vettraino, M., \& Di Stefano, G. (2010). Impairment of aerobic glycolysis by inhibitors of lactic dehydrogenase hinders the growth of human hepatocellular carcinoma cell lines. Pharmacology. https://doi.org/10.1159/000317519.

Floor, L., Dumont, J. E., Maenhaut, C., \& Raspe, E. (2012). Hallmarks of cancer : of all cancer cells, all the time? Trends in Mol Med, 18(9), 509-515.

Freedman, R. A., \& Partridge, A. H. (2011). Adjuvant therapies for very young women with early stage breast cancer. Breast (Edinburgh, Scotland), 20 Supp/ 3, S1469. https://doi.org/10.1016/S0960-9776(11)70313-7.

Froissart, R., Piraud, M., Boudjemline, A. M., Vianey-Saban, C., Petit, F., HubertBuron, A., Labrune, P. (2011). Glucose-6-phosphatase deficiency. Orphanet Journal of Rare Diseases. https://doi.org/10.1186/1750-1172-6-27.

Fu, L., Wen, X., Bao, J., \& Liu, B. (2012). MicroRNA-modulated autophagic signaling networks in cancer. The International Journal of Biochemistry \& Cell Biology, 44(5), 733-736. https://doi.org/10.1016/j.biocel.2012.02.004.

Fujioka, Y., Suzuki, S. W., Yamamoto, H., Kondo-Kakuta, C., Kimura, Y., Hirano, H., ... Noda, N. N. (2014). Structural basis of starvation-induced assembly of the autophagy initiation complex. Nature Structural and Molecular Biology, 21(6), 513-521. https://doi.org/10.1038/nsmb.2822.

Funderburk, S. F., Wang, Q. J., \& Yue, Z. (2010). The Beclin 1-VPS34 complex - at the crossroads of autophagy and beyond. Trends in Cell Biology. https://doi.org/10.1016/j.tcb.2010.03.002.

Galluzzi, L., Kepp, O., \& Kroemer, G. (2012). Mitochondria: Master regulators of danger signalling. Nature Reviews Molecular Cell Biology. https://doi.org/10.1038/nrm3479.

Ganapathy, V., Thangaraju, M., \& Prasad, P. D. (2009). Nutrient transporters in cancer: Relevance to Warburg hypothesis and beyond. Pharmacology and 
Therapeutics. https://doi.org/10.1016/j.pharmthera.2008.09.005.

García-Castillo, V., López-Urrutia, E., Villanueva-Sánchez, O., Á Ávila-Rodríguez, M., Zentella-Dehesa, A., Cortés-González, C., Pérez-Plasencia, C. (2017). Targeting Metabolic Remodeling in Triple Negative Breast Cancer in a Murine Model. Journal of Cancer, 8(7), 178-189. https://doi.org/10.7150/jca.16387.

Gatenby, R. A., \& Gillies, R. J. (2008). A microenvironmental model of carcinogenesis. Nature Reviews Cancer. https://doi.org/10.1038/nrc2255

Gibson, S. B. (2010). A matter of balance between life and death: Targeting reactive oxygen species (ROS)-induced autophagy for cancer therapy. Autophagy. https://doi.org/10.4161/auto.6.7.13335.

Gilmore, J. H. (2008). An efficient and reproducible process for transmission electron microscopy (TEM) of rare cell populations. North, 29(10), 1883-1889. https://doi.org/10.3174/ajnr.A1256.Functional

Gjorevski, N., \& Nelson, C. M. (2011). Integrated morphodynamic signalling of the mammary gland. Nature Reviews Molecular Cell Biology, 12(9), 581-593. https://doi.org/10.1038/nrm3168.

Glick, D., Barth, S., \& Macleod, K. F. (2010, May). Autophagy: Cellular and molecular mechanisms. Journal of Pathology. https://doi.org/10.1002/path.2697

Gonzalez, C. D., Alvarez, S., Ropolo, A., Rosenzvit, C., Gonzalez Bagnes, M. F., \& Vaccaro, M. I. (2014). Autophagy, warburg, and warburg reverse effects in human cancer. BioMed Research International, 2014. https://doi.org/10.1155/2014/926729.

Goode, E. L., Ulrich, C. M., \& Potter, J. D. (2002). Polymorphisms in DNA repair genes and associations with cancer risk. Cancer Epidemiology, Biomarkers \& Prevention: A Publication of the American Association for Cancer Research, Cosponsored by the American Society of Preventive Oncology, 11(12), 15131530.

Greenwood, H. I., Heller, S. L., Kim, S., Sigmund, E. E., Shaylor, S. D., \& Moy, L. (2013). Ductal Carcinoma in Situ of the Breasts: Review of MR Imaging Features. Radiographics: A Review Publication of the Radiological Society of North America, Inc, 33(6), 1569-1588. https://doi.org/10.1148/rg.336125055.

Gross, A., \& Katz, S. G. (2017). Non-apoptotic functions of BCL-2 family proteins. Cell Death and Differentiation. https://doi.org/10.1038/cdd.2017.22.

Gudjonsson, T., Adriance, M. C., Sternlicht, M. D., Petersen, O. W., \& Bissell, M. J. (2005). Myoepithelial Cells: Their Origin and Function in Breast Morphogenesis and Neoplasia. Journal of Mammary Gland Biology and Neoplasia, 10(3), 261272. https://doi.org/10.1007/s10911-005-9586-4.

Gump, J. M., \& Thorburn, A. (2011). Autophagy and apoptosis: What is the connection? Trends in Cell Biology, 21(7), 387-392. https://doi.org/10.1016/j.tcb.2011.03.007.

Gupta, V., \& Bamezai, R. N. K. (2010). Human pyruvate kinase M2: A multifunctional protein. Protein Science, 19(11), 2031-2044. https://doi.org/10.1002/pro.505.

Hanahan, D., \& Weinberg, R. A. (2011). Hallmarks of cancer: The next generation. Cell, 144(5), 646-674. https://doi.org/10.1016/j.cell.2011.02.013.

Hatoum, D., \& Mcgowan, E. M. (2015). Review Article Recent Advances in the Use of 
Metformin : Can Treating Diabetes Prevent Breast Cancer ?, 2015.

Held-Warmkessel, J., \& Dell, D. D. (2014). Lactic Acidosis in Patients With Cancer. Clinical Journal of Oncology Nursing, 18(5), 592-594 3p. https://doi.org/10.1188/14.CJON.592-594.

Hill, R., Song, Y., Cardiff, R. D., \& Van Dyke, T. (2005). Selective evolution of stromal mesenchyme with p53 loss in response to epithelial tumorigenesis. Cell, 123(6), 1001-1011. https://doi.org/10.1016/j.cell.2005.09.030.

Honrado, E., Benítez, J., \& Palacios, J. (2005). The molecular pathology of hereditary breast cancer: genetic testing and therapeutic implications. Modern Pathology: An Official Journal of the United States and Canadian Academy of Pathology, Inc, 18(10), 1305-20. https://doi.org/10.1038/modpathol.3800453.

Hoogeveen-Westerveld, M., Van Unen, L., Van Den Ouweland, A., Halley, D., Hoogeveen, A., \& Nellist, M. (2012). The TSC1-TSC2 complex consists of multiple TSC1 and TSC2 subunits. BMC Biochemistry, 13(1). https://doi.org/10.1186/1471-2091-13-18.

Horn, J., Åsvold, B. O., Opdahl, S., Tretli, S., \& Vatten, L. J. (2013). Reproductive factors and the risk of breast cancer in old age: A Norwegian cohort study. Breast Cancer Research and Treatment, 139(1), 237-243. https://doi.org/10.1007/s10549-013-2531-0.

Høyer-Hansen, M., Bastholm, L., Szyniarowski, P., Campanella, M., Szabadkai, G., Farkas, T., ... Jäättelä, M. (2007). Control of Macroautophagy by Calcium, Calmodulin-Dependent Kinase Kinase- $\beta$, and Bcl-2. Molecular Cell, 25(2), 193205. https://doi.org/10.1016/j.molcel.2006.12.009.

Huang, J., Dibble, C. C., Matsuzaki, M., \& Manning, B. D. (2008). The TSC1-TSC2 complex is required for proper activation of mTOR complex 2. Molecular and Cellular Biology, 28(12), 4104-15. https://doi.org/10.1128/MCB.00289-08.

Ignatiadis, M., Singhal, S. K., Desmedt, C., Haibe-Kains, B., Criscitiello, C., Andre, F., ... Sotiriou, C. (2012). Gene modules and response to neoadjuvant chemotherapy in breast cancer subtypes: A pooled analysis. Journal of Clinical Oncology, 30(16), 1996-2004. https://doi.org/10.1200/JCO.2011.39.5624.

INEGI., I. N. de gepgrafía y E. . (2013). Estadísticas a propósito del día mundial contra el cáncer. Retrieved from www.inegi.org. $\mathrm{mx} /$ inegi/contenidos/espanol/prensa/Co?.

Inzucchi, S. E., Bergenstal, R. M., Buse, J. B., Diamant, M., Ferrannini, E., Nauck, M., European Association for the Study of Diabetes (EASD). (2012). Management of hyperglycemia in type 2 diabetes: a patient-centered approach: position statement of the American Diabetes Association (ADA) and the European Association for the Study of Diabetes (EASD). Diabetes Care, 35(6), 1364-1379. https://doi.org/10.2337/dc12-0413.

Jalving, M., Gietema, J. A., Lefrandt, J. D., Jong, S. De, Reyners, A. K. L., Gans, R. O. B., \& Vries, E. G. E. D. (2010). Metformin: Taking away the candy for cancer? European Journal of Cancer, 46(13), 2369-2380. https://doi.org/10.1016/j.ejca.2010.06.012.

Jemal, A., Bray, F., Center, M. M., Ferlay, J., Ward, E., \& Forman, D. (2011). Global Cancer Statistics. CA Cancer J Clin, 61, 69-90. 
https://doi.org/10.3322/caac.20107.

Jung, S., Wang, M., Anderson, K., Baglietto, L., Bergkvist, L., Bernstein, L., ... Gapstur, S. M. (2015). Alcohol consumption and breast cancer risk by estrogen receptor status: in a pooled analysis of 20 studies. International Journal of Epidemiology, 1-13. https://doi.org/10.1093/ije/dyv156.

Kalender, A., Selvaraj, A., Kim, S. Y., Gulati, P., Brûlé, S., Viollet, B., Thomas, G. (2010). Metformin, independent of AMPK, inhibits mTORC1 in a rag GTPasedependent manner. Cell Metabolism, 11(5), 390-401. https://doi.org/10.1016/j.cmet.2010.03.014.

Kang, R., Zeh, H. J., Lotze, M. T., \& Tang, D. (2011). The Beclin 1 network regulates autophagy and apoptosis. Cell Death and Differentiation. https://doi.org/10.1038/cdd.2010.191.

Kapahi, P., Chen, D., Rogers, A. N., Katewa, S. D., Li, P. W. L., Thomas, E. L., \& Kockel, L. (2010). With TOR, less is more: A key role for the conserved nutrientsensing TOR pathway in aging. Cell Metabolism. https://doi.org/10.1016/j.cmet.2010.05.001.

Kelley, M. R., Logsdon, D., \& Fishel, M. L. (2014). Targeting DNA repair pathways for cancer treatment: what's new? Future Oncology, 10(7), 1215-1237. https://doi.org/10.2217/fon.14.60.

Kenific, C., \& Debnath, J. (2015). Cellular and metabolic functions for autophagy in cancer cells. Trends in Cell Biology, 25(1), 37-45. https://doi.org/10.1016/j.tcb.2014.09.001.

Keulers, T. G., Schaaf, M. B. E., \& Rouschop, K. M. A. (2016). Autophagy-Dependent Secretion: Contribution to Tumor Progression. Frontiers in Oncology, 6(November). https://doi.org/10.3389/fonc.2016.00251.

Key, T. (2013). Sex hormones and risk of breast cancer in premenopausal women: A collaborative reanalysis of individual participant data from seven prospective studies. The Lancet Oncology, 14(10), 1009-1019. https://doi.org/10.1016/S1470-2045(13)70301-2.

Kieran, M. W., Kalluri, R., \& Cho, Y.-J. (2012). The VEGF pathway in cancer and disease: responses, resistance, and the path forward. Cold Spring Harbor Perspectives in Medicine, 2(12), a006593. https://doi.org/10.1101/cshperspect.a006593.

Kim, M. K., Suh, D. H., Seoung, J., Kim, H. S., Chung, H. H., \& Song, Y. S. (2012). Autophagy as a target for anticancer therapy and its modulation by phytochemicals. In Journal of Food and Drug Analysis (Vol. 20, pp. 241-245). https://doi.org/10.1038/nrclinonc.2011.71.

Kim, M. P., Zhang, Y., \& Lozano, G. (2015). Mutant p53: Multiple Mechanisms Define Biologic Activity in Cancer. Frontiers in Oncology, 5. https://doi.org/10.3389/fonc.2015.00249.

Kispert, S., \& McHowat, J. (2017). Recent insights into cigarette smoking as a lifestyle risk factor for breast cancer. Breast Cancer (Dove Medical Press), 9, 127-132. https://doi.org/10.2147/BCTT.S129746.

Kiyomiya, K. I., Matsuo, S., \& Kurebe, M. (2001). Mechanism of specific nuclear transport of adriamycin: The mode of nuclear translocation of adriamycin- 
proteasome complex. Cancer Research, 61(6), 2467-2471.

Lal, S., Mahajan, A., Chen, W. N., \& Chowbay, B. (2010). Pharmacogenetics of target genes across doxorubicin disposition pathway: a review. Current Drug Metabolism, 11(1), 115-28. https://doi.org/10.2174/138920010791110890.

Lamanna, C., Monami, M., Marchionni, N., \& Mannucci, E. (2011). Effect of metformin on cardiovascular events and mortality: a meta-analysis of randomized clinical trials. Diabetes, Obesity \& Metabolism, 13(3), 221-228. https://doi.org/10.1111/j.1463-1326.2010.01349.x.

Lane, A. N., Fan, T. W. M., \& Higashi, R. M. (2009). Metabolic acidosis and the importance of balanced equations. Metabolomics, 5(2), 163-165. https://doi.org/10.1007/s11306-008-0142-2.

Laplante, M., \& Sabatini, D. M. (2012). mTOR signaling. Cold Spring Harbor Perspectives in Biology, 4(2). https://doi.org/10.1101/cshperspect.a011593

Le, A., Cooper, C. R., Gouw, A. M., Dinavahi, R., Maitra, A., Deck, L. M., Dang, C. V. (2010). Inhibition of lactate dehydrogenase A induces oxidative stress and inhibits tumor progression. Proceedings of the National Academy of Sciences of the United States of America, 107(5), 2037-2042. https://doi.org/10.1073/pnas.0914433107.

Lee, E. W., Seo, J., Jeong, M., Lee, S., \& Song, J. (2012). The roles of FADD in extrinsic apoptosis and necroptosis. BMB Reports. https://doi.org/10.5483/BMBRep.2012.45.9.186.

Levine, A. J., \& Puzio-Kuter, A. M. (2010). The control of the metabolic switch in cancers by oncogenes and tumor suppressor genes. Science (New York, N.Y.), 330(6009), 1340-1344. https://doi.org/10.1126/science.1193494.

Levine, B., \& Klionsky, D. J. (2004). Development by self-digestion: Molecular mechanisms and biological functions of autophagy. Developmental Cell. https://doi.org/10.1016/S1534-5807(04)00099-1.

Levine, B., \& Kroemer, G. (2008). Autophagy in the Pathogenesis of Disease. Cell, 132(1), 27-42. https://doi.org/10.1016/j.cell.2007.12.018.

Libby, G., Donnelly, L. A., Donnan, P. T., Alessi, D. R., Morris, A. D., \& Evans, J. M. M. (2009). New users of metformin are at low risk of incident cancer: A cohort study among people with type 2 diabetes. Diabetes Care. https://doi.org/10.2337/dc08-2175.

Liu, E. Y., \& Ryan, K. M. (2012). Autophagy and cancer--issues we need to digest. Journal of Cell Science, 125(Pt 10), 2349-58. https://doi.org/10.1242/jcs.093708.

Ljungman, M. (2009). Targeting the DNA damage response in cancer. Chemical Reviews, 109(7), 2929-2950. https://doi.org/10.1021/cr900047g.

Loos, B., Engelbrecht, A. M., Lockshin, R. A., Klionsky, D. J., \& Zakeri, Z. (2013). The variability of autophagy and cell death susceptibility: Unanswered questions. Autophagy, 9(9), 1270-1285. https://doi.org/10.4161/auto.25560.

Lorusso, G., \& Rüegg, C. (2008). The tumor microenvironment and its contribution to tumor evolution toward metastasis. Histochemistry and Cell Biology. https://doi.org/10.1007/s00418-008-0530-8.

Lukong, K. E. (2017). Understanding Breast Cancer - The long and winding road. $B B A$

Clinical, 7 ,

64-77. 
https://doi.org/http://dx.doi.org/10.1016/j.bbacli.2017.01.001.

Lunt, S. Y., \& Vander Heiden, M. G. (2011). Aerobic Glycolysis: Meeting the Metabolic Requirements of Cell Proliferation. Annual Review of Cell and Developmental Biology, 27(1), 441-464. https://doi.org/10.1146/annurev-cellbio$092910-154237$.

MacFarlane, L.-A., \& R. Murphy, P. (2010). MicroRNA: Biogenesis, Function and Role in Cancer. Current Genomics, 11(7), 537-561. https://doi.org/10.2174/138920210793175895.

Macintosh, R. L., \& Ryan, K. M. (2013). Autophagy in tumour cell death. Seminars in Cancer Biology, $23(5)$

344-351. https://doi.org/10.1016/j.semcancer.2013.05.006.

Maida, A., Lamont, B. J., Cao, X., \& Drucker, D. J. (2011). Metformin regulates the incretin receptor axis via a pathway dependent on peroxisome proliferatoractivated receptor- $\alpha$ in mice. Diabetologia, 54(2), 339-349. https://doi.org/10.1007/s00125-010-1937-z.

Maiese, K. (2015). Programming Apoptosis and Autophagy with Novel Approaches for Diabetes Mellitus, 12(2), 173-188.

Maiuri, M. C., Zalckvar, E., Kimchi, A., \& Kroemer, G. (2007). Self-eating and selfkilling: Crosstalk between autophagy and apoptosis. Nature Reviews Molecular Cell Biology. https://doi.org/10.1038/nrm2239.

Majeed, W., Aslam, B., Javed, I., Khaliq, T., Muhammad, F., Ali, A., \& Raza, A. (2014). Breast cancer: major risk factors and recent developments in treatment. Asian Pacific Journal of Cancer Prevention: APJCP, 15, 3353-3358. https://doi.org/10.7314/APJCP.2014.15.8.3353.

Makki, J. (2015). Diversity of breast carcinoma: Histological subtypes and clinical relevance. Clinical Medicine Insights: Pathology, 8(1), 23-31. https://doi.org/10.4137/CPath.s31563.

Martínez-Montañez, O. G., Uribe-Zúñiga, P., \& Hernández-Avila, M. (2009). [Public policies for the detection of breast cancer in Mexico]. Salud Pública De México, 51 Suppl 2, s350-s360.

Martinou, J. C., \& Youle, R. J. (2011). Mitochondria in Apoptosis: Bcl-2 Family Members and Mitochondrial Dynamics. Developmental Cell. https://doi.org/10.1016/j.devcel.2011.06.017.

Masood, S. (2016). Breast Cancer Subtypes: Morphologic and Biologic Characterization. Women's Health, 12(1), 103-119. https://doi.org/10.2217/whe.15.99.

Massagué, J., \& Obenauf, A. C. (2016). Metastatic colonization by circulating tumour cells. Nature. https://doi.org/10.1038/nature17038.

Massihnia, D., Galvano, A., Fanale, D., Perez, A., Castiglia, M., Incorvaia, L., Russo, A. (2016). Triple negative breast cancer: shedding light onto the role of pi3k/akt/mtor pathway. Oncotarget, 7(37), 60712-60722. https://doi.org/10.18632/oncotarget.10858.

Mathe, A., Scott, R. J., \& Avery-Kiejda, K. A. (2015). MiRNAs and other epigenetic changes as biomarkers in triple negative breast cancer. International Journal of Molecular Sciences. https://doi.org/10.3390/ijms161226090. 
Mediani, L., Gibellini, F., Bertacchini, J., Frasson, C., Bosco, R., Accordi, B., ... Marmiroli, S. (2016). Reversal of the glycolytic phenotype of primary effusion lymphoma cells by combined targeting of cellular metabolism and PI3K/Akt/ mTOR signaling. Oncotarget, https://doi.org/10.18632/oncotarget.6315.

Miao, P., Sheng, S., Sun, X., Liu, J., \& Huang, G. (2013). Lactate dehydrogenase a in cancer: A promising target for diagnosis and therapy. IUBMB Life. https://doi.org/10.1002/iub.1216.

Miskimins, W. K., Ahn, H. J., Kim, J. Y., Ryu, S., Jung, Y. S., \& Choi, J. Y. (2014). Synergistic anti-cancer effect of phenformin and oxamate. PLOS ONE, 9(1). https://doi.org/10.1371/journal.pone.0085576.

Mizushima, N., Levine, B., Cuervo, A. M., \& Klionsky, D. J. (2008). Autophagy fights disease through cellular self-digestion. Nature. https://doi.org/10.1038/nature06639.

Morrow, M., Waters, J., \& Morris, E. (2011). MRI for breast cancer screening, diagnosis, and treatment. The Lancet, 378(9805), 1804-1811. https://doi.org/10.1016/S0140-6736(11)61350-0.

Morselli, E., Galluzzi, L., Kepp, O., Vicencio, J.-M., Criollo, A., Maiuri, M. C., \& Kroemer, G. (2009). Anti- and pro-tumor functions of autophagy. Biochimica et Biophysica Acta (BBA) - Molecular Cell Research, 1793(9), 1524-1532. https://doi.org/10.1016/j.bbamcr.2009.01.006.

Moumen, M., Chiche, A., Cagnet, S., Petit, V., Raymond, K., Faraldo, M. M., ... Glukhova, M. A. (2011). The mammary myoepithelial cell. The International Journal of Developmental Biology, 55(7-8-9), 763-771. https://doi.org/10.1387/ijdb.113385mm.

Mowers, E. E., Sharifi, M. N., \& Macleod, K. F. (2017). Autophagy in cancer metastasis. Oncogene, 36(12), 1619-1630. https://doi.org/10.1038/onc.2016.333

Nagini, S. (2017). Breast Cancer: Current Molecular Therapeutic Targets and New Players. Anti-Cancer Agents in Medicinal Chemistry, 17(2), 152-163. https://doi.org/10.2174/1871520616666160502122724.

Nakatogawa, H. (2013). Two ubiquitin-like conjugation systems that mediate membrane formation during autophagy. Essays In Biochemistry, 55, 39-50. https://doi.org/10.1042/bse0550039.

Nakatogawa, H., \& Ohsumi, Y. (2014). Autophagy: Close contact keeps out the uninvited. Current Biology, 24(12), 560-562. https://doi.org/10.1016/j.cub.2014.05.013.

Nath, K., Nelson, D. S., Heitjan, D. F., Leeper, D. B., Zhou, R., \& Glickson, J. D. (2015). Lonidamine induces intracellular tumor acidification and ATP depletion in breast, prostate and ovarian cancer xenografts and potentiates response to doxorubicin. NMR in Biomedicine, 28(3), 281-290. https://doi.org/10.1002/nbm.3240.

Naudé, P. J. W., den Boer, J. a, Luiten, P. G. M., \& Eisel, U. L. M. (2011). Tumor necrosis factor receptor cross-talk. The FEBS Journal, 278(6), 888-98. https://doi.org/10.1111/j.1742-4658.2011.08017.x.

O'Shaughnessy, J., Schwartzberg, L., Danso, M. A., Miller, K. D., Rugo, H. S., 
Neubauer, M., Winer, E. P. (2014). Phase III study of iniparib plus gemcitabine and carboplatin versus gemcitabine and carboplatin in patients with metastatic triple-negative breast cancer. Journal of Clinical Oncology: Official Journal of the American Society of Clinical Oncology, 32(34), 3840-7. https://doi.org/10.1200/JCO.2014.55.2984.

Okoshi, R., Ozaki, T., Yamamoto, H., Ando, K., Koida, N., Ono, S., Kizaki, H. (2008). Activation of AMP-activated protein kinase induces p53-dependent apoptotic cell death in response to energetic stress. The Journal of Biological Chemistry, 283(7), 3979-87. https://doi.org/10.1074/jbc.M705232200.

Ouyang, L., Shi, Z., Zhao, S., Wang, F. T., Zhou, T. T., Liu, B., \& Bao, J. K. (2012). Programmed cell death pathways in cancer: A review of apoptosis, autophagy and programmed necrosis. Cell Proliferation, 45(6), 487-498. https://doi.org/10.1111/j.1365-2184.2012.00845.x.

Paluch-Shimon, S., Cardoso, F., Sessa, C., Balmana, J., Cardoso, M. J., Gilbert, F., on behalf of the ESMO Guidelines Committee. (2016). Prevention and screening in BRCA mutation carriers and other breast/ovarian hereditary cancer syndromes: ESMO clinical practice guidelines for cancer prevention and screening. Annals of Oncology, 27, v103-v110. https://doi.org/10.1093/annonc/mdw327.

Paulmurugan, R. (2012). Introduction to Cancer Biology. In Molecular Imaging Probes for Cancer Research (pp. 3-27). https://doi.org/10.1142/9789814293686_0001

Peláez-García, A., Yébenes, L., Berjón, A., Angulo, A., Zamora, P., Ignacio, J., Hardisson. (2017). Comparison of risk classification between EndoPredict and MammaPrint in ER-positive / HER2-negative primary invasive breast cancer. PLOS ONE, 1-12.

Pennarun, B., Meijer, A., de Vries, E. G. E., Kleibeuker, J. H., Kruyt, F., \& de Jong, S. (2010). Playing the DISC: Turning on TRAIL death receptor-mediated apoptosis in cancer. Biochimica et Biophysica Acta - Reviews on Cancer. https://doi.org/10.1016/j.bbcan.2009.11.004.

Perl, A. (2015). MTOR activation is a biomarker and a central pathway to autoimmune disorders, cancer, obesity, and aging. Annals of the New York Academy of Sciences, 1346(1), 33-44. https://doi.org/10.1111/nyas.12756.

Perou, C. M. (2011). Molecular Stratification of Triple-Negative Breast Cancers. The Oncologist, 16(Supplement 1), 61-70. https://doi.org/10.1634/theoncologist.2011-S1-61.

Perou, C. M., Sørile, T., Eisen, M. B., Van De Rijn, M., Jeffrey, S. S., Ress, C. A., Botstein, D. (2000). Molecular portraits of human breast tumours. Nature, 406(6797), 747-752. https://doi.org/10.1038/35021093.

Pisano, E. D., Hendrick, R. E., Yaffe, M. J., Baum, J. K., Acharyya, S., Cormack, J. B., Gatsonis, C. A. (2008). Diagnostic Accuracy of Digital versus Film Mammography: Exploratory Analysis of Selected Population Subgroups in DMIST. Radiology, 246(2), 376-383. https://doi.org/10.1148/radiol.2461070200.

Plate, K. H., Scholz, A., \& Dumont, D. J. (2012). Tumor angiogenesis and antiangiogenic therapy in malignant gliomas revisited. Acta Neuropathologica, 124(6), 763-775. https://doi.org/10.1007/s00401-012-1066-5. 
Pollak, M. (2014). Repurposing biguanides to target energy metabolism for cancer treatment. Nature Medicine. https://doi.org/10.1038/nm.3596.

Prat, A., \& Perou, C. M. (2010). Deconstructing the molecular portraits of breast cancer, 5, 5-23. https://doi.org/10.1016/j.molonc.2010.11.003

Pyo, J. O., Jang, M. H., Kwon, Y. K., Lee, H. J., Jun, J. II, Woo, H. N., Jung, Y. K. (2005). Essential roles of Atg5 and FADD in autophagic cell death: Dissection of autophagic cell death into vacuole formation and cell death. Journal of Biological Chemistry, 280(21), 20722-20729. https://doi.org/10.1074/jbc.M413934200.

Qu, X., Yu, J., Bhagat, G., Furuya, N., Hibshoosh, H., Troxel, A., Levine, B. (2003). Promotion of tumorigenesis by heterozygous disruption of the beclin 1 autophagy gene. Journal of Clinical Investigation, 112(12), 1809-1820. https://doi.org/10.1172/JCl200320039.

Quennet, V., Yaromina, A., Zips, D., Rosner, A., Walenta, S., Baumann, M., \& Mueller-Klieser, W. (2006). Tumor lactate content predicts for response to fractionated irradiation of human squamous cell carcinomas in nude mice. Radiotherapy and Oncology, 81(2), 130-135. https://doi.org/10.1016/j.radonc.2006.08.012.

Radoshevich, L., Murrow, L., Chen, N., Fernandez, E., Roy, S., Fung, C., \& Debnath, J. (2010). ATG12 conjugation to ATG3 regulates mitochondrial homeostasis and cell death. Cell, 142(4), 590-600. https://doi.org/10.1016/j.cell.2010.07.018.

Reddy, K. B. (2011). Triple-negative breast cancers: an updated review on treatment options. Current Oncology (Toronto, Ont.), 18(4), e173-9. Retrieved from http://www.pubmedcentral.nih.gov/articlerender.fcgi?artid=3149549\&tool=pmcent rez\&rendertype $=$ abstract.

Release, P. (2013). Latest world cancer statistics Global cancer burden rises to 14 . 1 million new cases in 2012: Marked increase in breast cancers must be addressed. International Agency for Research on Cancer, World Health Organization, (December), 2012-2014. https://doi.org/223.

Rimawi, M. F., Schiff, R., \& Osborne, C. K. (2015). Targeting HER2 for the Treatment of Breast Cancer. Annual Review of Medicine, 66(1), 111-128. https://doi.org/10.1146/annurev-med-042513-015127.

Rivera-Franco Monica M, \& Leon-Rodriguez Eucario. (2017). Delays in Breast Cancer Detection and Treatment in Developing Countries. Breast Cancer: Basic and Clinical Research, 12, 1-5. https://doi.org/10.1177/1178223417752677.

Rohn, T. T., Wirawan, E., Brown, R. J., Harris, J. R., Masliah, E., \& Vandenabeele, P. (2011). Depletion of Beclin-1 due to proteolytic cleavage by caspases in the Alzheimer's disease brain. Neurobiology of Disease, 43(1), 68-78. https://doi.org/10.1016/j.nbd.2010.11.003.

Ropka, M. E., Keim, J., \& Philbrick, J. T. (2010). Patient decisions about breast cancer chemoprevention: a systematic review and meta-analysis. Journal of Clinical Oncology: Official Journal of the American Society of Clinical Oncology, 28(18), 3090-5. https://doi.org/10.1200/JCO.2009.27.8077.

Rosenfeldt, M. T., \& Ryan, K. M. (2011). The multiple roles of autophagy in cancer. Carcinogenesis. https://doi.org/10.1093/carcin/bgr031.

Safe, S. (2015). Targeting apoptosis pathways in cancer - Letter. Cancer Prevention 
Research. https://doi.org/10.1158/1940-6207.CAPR-14-0405.

Sakurai, T., \& Kudo, M. (2011). Signaling pathways governing tumor angiogenesis. Oncology. https://doi.org/10.1159/000333256.

Sambrook, J., \& Russell, D. W. (2001). Molecular Cloning - Sambrook \& Russel - Vol. 1, 2, 3.pdf. Human Mutation. https://doi.org/10.1002/humu.1186.abs.

Sánchez-Forgacha, E. R., Carpinteyro-Espínb, U., Alemán-Ávilesc, J. A., \& SánchezBasurto, C. (2017). Validación y aplicación clínica de MammaPrint en pacientes con cáncer de mama, 85(4), 320-324.

Sceneay, J., Smyth, M. J., \& Möller, A. (2013). The pre-metastatic niche: Finding common ground. Cancer and Metastasis Reviews. https://doi.org/10.1007/s10555-013-9420-1.

Schieke, S. M., Phillips, D., McCoy, J. P., Aponte, A. M., Shen, R.-F., Balaban, R. S., \& Finkel, T. (2006). The mammalian target of rapamycin (mTOR) pathway regulates mitochondrial oxygen consumption and oxidative capacity. The Journal of Biological Chemistry, 281(37), 27643-52. https://doi.org/10.1074/jbc.M603536200.

Shen, S., Kepp, O., \& Kroemer, G. (2012). The end of autophagic cell death? Autophagy. https://doi.org/10.4161/auto.8.1.16618.

Shpilka, T., Weidberg, H., Pietrokovski, S., \& Elazar, Z. (2011). Atg8: An autophagyrelated ubiquitin-like protein family. Genome Biology, 12(7). https://doi.org/10.1186/gb-2011-12-7-226.

Siegel, R. L., Miller, K. D., \& Jemal, A. (2017). Cancer statistics, 2017. CA: A Cancer Journal for Clinicians, 67(1), 7-30. https://doi.org/10.3322/caac.21387

Simonsen, A., \& Tooze, S. A. (2009). Coordination of membrane events during autophagy by multiple class III PI3-kinase complexes. Journal of Cell Biology. https://doi.org/10.1083/jcb.200907014.

Soga, T. (2013). Cancer metabolism: Key players in metabolic reprogramming. Cancer Science, 104(3), 275-281. https://doi.org/10.1111/cas.12085.

Sotiriou, C., \& Pusztai, L. (2009). Gene-Expression Signatures in Breast Cancer. New England Journal of Medicine, 360(8), 790-800. https://doi.org/10.1056/NEJMra0801289.

Su, M., Mei, Y., \& Sinha, S. (2013). Role of the crosstalk between autophagy and apoptosis in cancer. Journal of Oncology. https://doi.org/10.1155/2013/102735

Sui, X., Xu, Y., Wang, X., Han, W., Pan, H., \& Xiao, M. (2015). Metformin: A Novel but Controversial Drug in Cancer Prevention and Treatment. Molecular Pharmaceutics, 12(11), 3783-3791. https://doi.org/10.1021/acs.molpharmaceut.5b00577.

Suman, S., Das, T., Reddy, R., Nyakeriga, A., Luevano, J., Konwar, D., Damodaran, C. (2014). The pro-apoptotic role of autophagy in breast cancer. British Journal of Cancer, 111(2), 309-317. https://doi.org/10.1038/bjc.2014.203.

Sun, Y., Liu, J. hua, Jin, L., Lin, S. mei, Yang, Y., Sui, Y. xia, \& Shi, H. (2010). Overexpression of the Beclin1 gene upregulates chemosensitivity to anti-cancer drugs by enhancing therapy-induced apoptosis in cervix squamous carcinoma CaSki cells. Cancer Letters, 294(2), 204-210. https://doi.org/10.1016/j.canlet.2010.02.001 
Svensson, R. U., \& Shaw, R. J. (2012). Cancer metabolism: Tumour friend or foe. Nature. https://doi.org/10.1038/485590a.

Swain, S. M., Baselga, J., Kim, S.-B., Ro, J., Semiglazov, V., Campone, M., ... Cortés, J. (2015). Pertuzumab, Trastuzumab, and Docetaxel in HER2-Positive Metastatic Breast Cancer. New England Journal of Medicine, 372(8), 724-734. https://doi.org/10.1056/NEJMoa1413513.

Swain, S. M., Kim, S. B., Cortés, J., Ro, J., Semiglazov, V., Campone, M., Baselga, J. (2013). Pertuzumab, trastuzumab, and docetaxel for HER2-positive metastatic breast cancer (CLEOPATRA study): Overall survival results from a randomised, double-blind, placebo-controlled, phase 3 study. The Lancet Oncology, 14(6), 461-471. https://doi.org/10.1016/S1470-2045(13)70130-X.

Tacar, O., Sriamornsak, P., \& Dass, C. R. (2013). Doxorubicin: An update on anticancer molecular action, toxicity and novel drug delivery systems. Journal of Pharmacy and Pharmacology. https://doi.org/10.1111/j.2042-7158.2012.01567.x.

Tanida, I., Ueno, T., \& Kominami, E. (2008). LC3 and autophagy. Methods in Molecular Biology, 445, 77-88. https://doi.org/10.1007/978-1-59745-157-4_4.

Tanos, T., Rojo, L., Echeverria, P., \& Brisken, C. (2012). ER and PR signaling nodes during mammary gland development. Breast Cancer Research: BCR, 14(4), 210. https://doi.org/10.1186/bcr3166.

Tekedereli, I., Alpay, S. N., Tavares, C. D. J., Cobanoglu, Z. E., Kaoud, T. S., Sahin, I., Ozpolat, B. (2012). Targeted silencing of elongation factor 2 kinase suppresses growth and sensitizes tumors to doxorubicin in an orthotopic model of breast cancer. PLoS ONE, 7(7). https://doi.org/10.1371/journal.pone.0041171.

Telang, S., Clem, B. F., Klarer, A. C., Clem, A. L., Trent, J. O., Bucala, R., \& Chesney, J. (2012). Small molecule inhibition of 6-phosphofructo-2-kinase suppresses $t$ cell activation. Journal of Translational Medicine, 10(1). https://doi.org/10.1186/1479-5876-10-95.

Teng, Y. H.-F., Tan, W.-J., Thike, A.-A., Cheok, P.-Y., Tse, G. M.-K., Wong, N.-S., ... Tan, P.-H. (2011). Mutations in the epidermal growth factor receptor (EGFR) gene in triple negative breast cancer: possible implications for targeted therapy. Breast Cancer Research, 13(2), R35. https://doi.org/10.1186/bcr2857.

Tennant, D. A., Durán, R. V., Boulahbel, H., \& Gottlieb, E. (2009). Metabolic transformation in cancer. Carcinogenesis, 30(8), 1269-1280. https://doi.org/10.1093/carcin/bgp070.

Thornburg, J. M., Nelson, K. K., Clem, B. F., Lane, A. N., Arumugam, S., Simmons, A., ... Chesney, J. (2008). Targeting aspartate aminotransferase in breast cancer. Breast Cancer Research, 10. https://doi.org/10.1186/bcr2154.

Tschan, M. P., \& Simon, H. U. (2010). The role of autophagy in anticancer therapy: Promises and uncertainties. In Journal of Internal Medicine (Vol. 268, pp. 410418). https://doi.org/10.1111/j.1365-2796.2010.02266.x.

Valentin, M. D., Da Silva, S. D., Privat, M., Alaoui-Jamali, M., \& Bignon, Y. J. (2012). Molecular insights on basal-like breast cancer. Breast Cancer Research and Treatment. https://doi.org/10.1007/s10549-011-1934-z.

Vander Heiden, M. G., Cantley, L. C., \& Thompson, C. B. (2009). Understanding the Warburg Effect: The Metabolic Requirements of Cell Proliferation. Science, 
324(5930), 1029-1033. https://doi.org/10.1126/science.1160809.

Vichai, V., \& Kirtikara, K. (2006). Sulforhodamine B colorimetric assay for cytotoxicity screening. Nature Protocols, 1(3), 1112-1116. https://doi.org/10.1038/nprot.2006.179.

Ward, R. A., Brassington, C., Breeze, A. L., Caputo, A., Critchlow, S., Davies, G., Hudson, K. (2012). Design and synthesis of novel lactate dehydrogenase a inhibitors by fragment-based lead generation. Journal of Medicinal Chemistry, 55(7), 3285-3306. https://doi.org/10.1021/jm201734r.

Wei, Y., Pattingre, S., Sinha, S., Bassik, M., \& Levine, B. (2008). JNK1-Mediated Phosphorylation of Bcl-2 Regulates Starvation-Induced Autophagy. Molecular Cell, 30(6), 678-688. https://doi.org/10.1016/j.molcel.2008.06.001.

Weinberg, R. a. (1995). The retinoblastoma protein and cell cycle control. Cell, 81(3), 323-330. https://doi.org/10.1016/0092-8674(95)90385-2.

Welti, J., Loges, S., Dimmeler, S., \& Carmeliet, P. (2013). Recent molecular discoveries in angiogenesis and antiangiogenic therapies in cancer. Journal of Clinical Investigation. https://doi.org/10.1172/JCl70212.

White, E. (2015). The role for autophagy in cancer. The Journal of Clinical Investigation, 125(1), 42-6. https://doi.org/10.1172/JCI73941.

Wirawan, E., Vande Walle, L., Kersse, K., Cornelis, S., Claerhout, S., Vanoverberghe, I., Vandenabeele, P. (2010). Caspase-mediated cleavage of Beclin-1 inactivates Beclin-1-induced autophagy and enhances apoptosis by promoting the release of proapoptotic factors from mitochondria. Cell Death and Disease. https://doi.org/10.1038/cddis.2009.16.

Wullschleger, S., Loewith, R., \& Hall, M. N. (2006). TOR signaling in growth and metabolism. Cell. https://doi.org/10.1016/j.cell.2006.01.016

Xia, H. G., Zhang, L., Chen, G., Zhang, T., Liu, J., Jin, M., Yuan, J. (2010). Control of basal autophagy by calpain1 mediated cleavage of ATG5. Autophagy, 6(1), 6166. https://doi.org/10.4161/auto.6.1.10326.

Xie, H., Hanai, J. I., Ren, J. G., Kats, L., Burgess, K., Bhargava, P., Seth, P. (2014). Targeting lactate dehydrogenase-A inhibits tumorigenesis and tumor progression in mouse models of lung cancer and impacts tumor-initiating cells. Cell Metabolism, 19(5). https://doi.org/10.1016/j.cmet.2014.03.003.

Xie, H., Valera, V. a, Merino, M. J., Amato, A. M., Signoretti, S., Linehan, W. M., Seth, P. (2009). LDH-A inhibition, a therapeutic strategy for treatment of hereditary leiomyomatosis and renal cell cancer. Molecular Cancer Therapeutics, 8(3), 626635. https://doi.org/10.1158/1535-7163.MCT-08-1049.

Xu, J., Ji, J., \& Yan, X. H. (2012). Cross-Talk between AMPK and mTOR in Regulating Energy Balance. Critical Reviews in Food Science and Nutrition. https://doi.org/10.1080/10408398.2010.500245.

Yadav, B. S., Sharma, S. C., Chanana, P., \& Jhamb, S. (2014). Systemic treatment strategies for triple-negative breast cancer. World Journal of Clinical Oncology, 5(2), 125-33. https://doi.org/10.5306/wjco.v5.i2.125.

Yang, Y., Su, D., Zhao, L., Zhang, D., Xu, J., Wan, J., Chen, M. (2014a). Different effects of LDH-A inhibition by oxamate in non-small cell lung cancer cells. Oncotarget, 5(23), 11886-96. https://doi.org/10.18632/oncotarget.2620. 
Yang, Y., Su, D., Zhao, L., Zhang, D., Xu, J., Wan, J., Chen, M. (2014b). Different effects of LDH-A inhibition by oxamate in non-small cell lung cancer cells. Oncotarget, 5(23), 11886-96. Retrieved from http://www.pubmedcentral.nih.gov/articlerender.fcgi?artid=4323009\&tool=pmcent rez\&rendertype $=$ abstract.

Yang, Y., Sun, M., Wang, L., \& Jiao, B. (2013). HIFs, angiogenesis, and cancer. Journal of Cellular Biochemistry, 114(5), 967-974. https://doi.org/10.1002/jcb.24438.

Yin, X., Cao, L., Peng, Y., Tan, Y., Xie, M., Kang, R., Tang, D. (2011). A critical role for UVRAG in apoptosis. Autophagy, 7(10), 1242-1244. https://doi.org/10.4161/auto.7.10.16507.

Yu, X., Mao, W., Zhai, Y., Tong, C., Liu, M., Ma, L., Li, S. (2017). Anti-tumor activity of metformin: from metabolic and epigenetic perspectives. Oncotarget, 8(3), 56195628. https://doi.org/10.18632/oncotarget.13639.

Zhou, F., Yang, Y., \& Xing, D. (2011). Bcl-2 and Bcl-xL play important roles in the crosstalk between autophagy and apoptosis. FEBS Journal, 278(3), 403-413. https://doi.org/10.1111/j.1742-4658.2010.07965.x.

Zhuang, Y., \& Miskimins, W. K. (2011). Metformin Induces Both Caspase-Dependent and Poly(ADP-ribose) Polymerase-Dependent Cell Death in Breast Cancer Cells. Molecular Cancer Research, 9(5), 603-615. https://doi.org/10.1158/15417786.MCR-10-0343 
13. A N EXOS 
Research Paper

\title{
Targeting Metabolic Remodeling in Triple Negative Breast Cancer in a Murine Model
}

\author{
Verónica García-Castillo1,2, Eduardo López-Urrutia1, Octavio Villanueva-Sánchez³, Miguel Á. \\ Ávila-Rodríguez ${ }^{4}$, Alejandro Zentella-Dehesa ${ }^{3}$, Carlo Cortés-González ${ }^{6}$, César López-Camarillo5, Nadia J \\ Jacobo-Herrera $^{3 凶}$, Carlos Pérez-Plasencia ${ }^{2,6 \bowtie}$ \\ 1. Posgrade in Experimental Biology, Metropolitan University of Mexico; \\ 2. FES-Iztacala, UBIMED, National Autonomous University of Mexico, UNAM, Tlalnepantla, Mexico; \\ 3. Biochemistry Unit, National Nutrition Institute of Mexico "Salvador Zubirán", Mexico; \\ 4. PET/CT Unit, Faculty of Medicine, UNAM; \\ 5. Posgrade in Genomic Sciences, Autonomous University of México City, Mexico; \\ 6. Genomics Lab, National Cancer Institute of Mexico, Mexico. \\ $\triangle$ Corresponding authors: Carlos Pérez-Plasencia, e-mail: carlos.pplas@gmail; Tel.: +52-55-5623-1333 (ext. 39807). Or Nadia J Jacobo-Herrera, e-mail: \\ nadia.jacobo@gmail.com. Tel.: +52-55-54870900 (ext. 2608). \\ (C) Ivyspring International Publisher. This is an open access article distributed under the terms of the Creative Commons Attribution (CC BY-NC) license \\ (https://creativecommons.org/licenses/by-nc/4.0/). See http://ivyspring.com/terms for full terms and conditions.
}

Received: 2016.06.05; Accepted: 2016.10.12; Published: 2017.01.13

\begin{abstract}
Background: Chemotherapy is the backbone of systemic treatment for triple negative breast cancer (TNBC), which is one of the most relevant breast cancers molecular types due to the ability of tumor cells to develop drug resistance, highlighting the urgent need to design newer and safer drug combinations for treatment. In this context, to overcome tumor cell drug resistance, we employed a novel combinatorial treatment including Doxorubicin, Metformin, and Sodium Oxamate (DoxMetOx). Such pharmacological combination targets indispensable hallmarks of cancer-related to aerobic glycolysis and DNA synthesis.

Materials and Methods: Thirty-five female nude mice were transplanted subcutaneously with MDA-MB-231 triple negative human cancer cell line. Once tumors were visible, mice were treated with doxorubicin, metformin, oxamate or all possible pharmacologic combinations. Treatments were administered daily for 15 days and tumors were measured by calipers every day. MicroPET images were taken in three different occasions, basal state, in the middle of the treatment, and at the end of treatment. Western blot analyses, qRT-PCR, flow cytometry, and cytotoxicity assays were performed to elucidate the mechanism of cell death promoted by the drugs in vitro.

Results: In this work we assessed the proof of concept of metabolic correction in solid tumors as an effective drug treatment; hence, mice bearing tumors treated with the DoxMetOx therapy showed a complete inhibition of the tumor mass growing in 15 days of treatment depicted by the micro PET images. In vitro studies displayed that the three drugs together act by inhibiting both, mTOR-phosphorylation and expression of LDH-A gene, promoting apoptosis via dependent on the caspase-3 pathway, accompanied by cleavage of PARP. Moreover, induction of autophagy process was observed by the accumulation of LC3-II, a primordial protein implicated in the conformation and elongation of the autophagolysosome.

Conclusions: The lack of effective drugs to inhibit TNBC growth is the main cause of therapy failure and tumor relapse. We have showed that targeting crucial molecular pathways in cancer by the combination of Doxorubicin, Metformin, and Oxamate resulted as an efficient and rapid tumor growth inhibitor in a triple negative xenograft model. Our findings are promising for patients diagnosed with TNBC tumors, for which unfortunately there are no reliable drug therapies.
\end{abstract}

Key words: Triple Negative Breast Cancer (TNBC), metformin, oxamate, doxorubicin, mTOR, aerobic glycolysis, xenograft, micro PET. 


\section{Introduction}

Breast cancer (BC) is a global health problem as a leading cause of cancer-related deaths in women (1). Only in 2012, nearly to 1.7 million new cases of BC were registered around the world, which represented close to $12 \%$ of all cancers in that year (2). About half the breast cancer cases and $60 \%$ of deaths are estimated to occur in economically developing countries. Currently, BC is classified into five major groups based on molecular profiling. Triple negative breast cancer (TNBC) is defined clinically as negative for estrogen and progesterone receptors (ER-negative, PR-negative) as well as negative for human epidermal growth factor receptor type 2 (HER2-negative) (3).

Worldwide, approximately $15 \%$ of breast tumors correspond to $\operatorname{TNBC}(4,5)$. At present, there is no specific therapy for these patients; however, the standard treatment consists of surgery, radiation and co-adjuvant treatments based on anthracyclines (doxorubicin, gemcitabine, capecitabine, vinorelbine, ixabepilone) and taxanes (6). The main consequences of current chemotherapy agents are cardiotoxicity, and both neuro- and hemato-toxicity in patients with prolonged treatments (6).

Solid tumors present a disturbed metabolism, i.e. glycolytic rate, and glucose absorption increments that in consequence produce high lactate concentrations, known as the Warburg effect or aerobic glycolysis (7). Thus, cancer cells require glucose as a primary source of energy to supply ATP to maintain their active metabolism and proliferation (8). A key enzyme regulating this process is the isoform $\mathrm{A}$ of the lactate dehydrogenase (LDH-A), which catalyzes the reversible conversion of lactate to pyruvate (9). Released lactate into the extracellular matrix increase cancer cell motility and invasion through the activation of metalloproteases (10). Besides can inhibit activation, differentiation and expression of antigens in dendritic cells (11). Hence, lactate has been proposed as an onco-metabolite (12). Tumor lactate content has been considered as a prognostic parameter in the clinic for cervical and head-and-neck cancers after observed that patients with high lactate concentration are likely to develop metastasis and to present lower survival probabilities $(13,14)$. All these distinctive attributes of tumor cells promise therapeutic targets. Hence, it is feasible to use selective drugs to inhibit directly glycolysis and ATP generation, promoting apoptosis in tumor cells with reduced cytotoxicity in normal cells.

Several findings support the use of oxamate (Ox)- a competitive inhibitor of LDH-A and aspartate aminotransferase (AAT)- as a glycolysis and cellular growth inhibitor in vitro and in vivo studies with HeLa cells, cervical, breast and astrocytoma cancer $(15,16,17,18,19,20)$. Moreover, since its chemical structure is very similar to pyruvate, it is likely to be safe for humans (20). It is known that once LDH-A is inhibited, levels of ATP diminish and mitochondrial reactive oxygen species (ROS) production increases, accelerating tumoral cell death through apoptosis $(20,21,22,23)$. Therefore, it is rational to assume that LDH-A inhibition blocks glycolysis and potentially provokes deleterious changes in the tumor metabolism.

Recently, evidence of Metformin -the most commonly prescribed antidiabetic drug for type II diabetes- as an anticancer drug has been gathering (24). Metformin inhibits proliferation in different cancer cell lines including breast, glial, prostate, and gastric cancer $(25,26,27,28)$ through the inhibition of the respiratory chain -complex 1-, decreasing ATP synthesis and thus producing an increment in the activity of the AMP-promoted kinase (AMPK) $(29,30)$. AMPK is a crucial regulator of lipids and glucose in response to metabolic alterations and intracellular levels of ATP (31). When AMPK is active, Mammalian Target of Rapamycin (mTOR) is inhibited and so are ATP-dependent processes such as protein, fatty acid, and cholesterol biosynthesis, as well as gluconeogenesis (32). A very new investigation demonstrated that the use of phenformin (a biguanide antidiabetic drug) together with oxamate is a potent anticancer formulation that leads to cell death by apoptosis in vitro, and reduces tumor growth in vivo (20).

With the previous evidence in mind, we hypothesize that drug-targeting molecular and metabolic pathways that are aberrantly-activated in tumor cells, we could inhibit tumor growth cell by inhibiting Warburg effect, and nucleic acid synthesis; activating apoptosis and autophagy. For that purpose, we used a combination of Doxorubicin, Metformin, and Sodium Oxamate (DoxMetOx). As a result, the pharmacological combination was able to dramatically reduce the tumor growth since the first administration. Moreover, in vitro analyses showed that apoptosis was activated and caspase- 3 and PARP were cleaved in cells treated with DoxMetOx. In addition, inhibition of mTOR phosphorylation occurred at the same time that LDH-A was inhibited, both at mRNA and protein levels. Such data suggest that both processes (mTOR phosphorylation and transcriptional activation of LDH-A) could be connected. Finally, treated cells with DoxMetOx also activated LC3-II, a molecular marker of autophagy. Taken together these results, strengthen the hypothesis that concurrent inhibition of mTOR and LDH-A leads tumor cells to activate apoptosis and 
autophagy. Our investigation sheds light to patients diagnosed with TNBC, a tumor with lower survival expectation than other breast cancer phenotypes.

\section{Methods}

\section{Drugs}

Doxorubicin (Doxolem) (Dox); Metformin (1-1dimethylbiguanidine hydrochloride, Santa Cruz ${ }^{\circledR}$ sc-202000A) (Met); Sodium Oxamate (Ox) (Santa Cruz sc-215880). Concentrations in vitro: as indicated. Dose in vivo: Met $200 \mathrm{mg} / \mathrm{Kg}$, Ox $15 \mathrm{mg} / \mathrm{Kg}$, and Dox 1 $\mathrm{mg} / \mathrm{Kg}$.

\section{Cell culture}

The MDA-MB-231 human mammary adenocarcinoma cells, with mutation in p53 and negative expression of epidermal growth factor receptor type 2 (HER2) receptor, they express low levels of androgen receptors, and are highly invasive, were purchased from the American Type Culture Collection (ATCC). Cells were cultured in GIBCO® RPMI-1640 media supplemented with 10\% FBS (Biowest ${ }^{\circledR}$ ), $5 \mathrm{~mL} / \mathrm{L}$ penicillin/streptomycin (GIBCO $\left.{ }^{\circledR}\right)$, and maintained at $37^{\circ} \mathrm{C}, 5 \% \mathrm{CO}_{2}$ in air and 95\% humidity.

\section{Cytotoxicity Assay by Sulforhodamine B (SRB) assay}

MDA-MB-231 cells were incubated in 96-well plates at a density of 7000 cells/well. The cells were treated with different concentrations of Dox, Met or Ox for 4, 24, 48 and $72 \mathrm{~h}$. In a separate plate (day 0), 7000 cells/well were seeded, incubated and allowed to attach for 4 hours. At the end of every incubation time, either with or without treatment, cells were fixed with cold trichloroacetic acid $10 \%$ (TCA) at $4^{\circ} \mathrm{C}$ for one h. TCA was removed, and plates washed with tap water and air dried. Finally, $100 \mu \mathrm{L}$ of SFR-B were added to each well and incubated at room temperature for $30 \mathrm{~min}$, wells were washed with $1 \%$ acetic acid to remove unbound dye. The dye was dissolved in $10 \mathrm{mM}$ Tris base solution ( $\mathrm{pH}$ 10.5) and stirred over $5 \mathrm{~min}$. Optical density (OD) was measured in an Epoch Microplate Spectrophotometer (Bio-Tek) at $510 \mathrm{~nm}$. Results are expressed as the concentration that inhibits $50 \%$ of control growth after the incubation period $\left(\mathrm{IC}_{50}\right)$. The values were estimated from a semi-log plot of the drug concentration $(\mathrm{mM} / \mathrm{mL}$ and $\mu \mathrm{M} / \mathrm{mL})$ against the percentage of growth inhibition (33).

\section{MDA-MB-231 subcutaneous xenograft model}

All in vivo experiments were performed following animal care guidelines approved by the Committee for Animal Research and Procedures of the National Nutrition Institute of Mexico "Salvador Zubirán" (Project No. 768). Thirty-five female nude mice (nu/nu) were used when they were 4-week-old, food and water were provided ad libitum, and animals were housed in cages with microisolators in a 12-h light and dark cycle. MDA-MB-231 cells $\left(10 \times 10^{6}\right.$ in $100 \mu \mathrm{L}$ of $0.9 \%$ saline solution) were implanted subcutaneously into the right flank of all mice and allowed to grow up to the subcutaneous xenografts tumors became visible (approximately $50 \mathrm{~mm}^{3}$ in size), mice were random assigned to be treated intraperitoneally for 15 days with all possible combination of drugs (as single treatment and combined drugs). Tumor sizes were measured by calipers every day and their volumes were calculated according to the formula of (width ${ }^{2} \times$ length) $/ 2$ (34). Hence, seven different groups of five mice each were treated as follows: 1) positive control, Dox $(1 \mathrm{mg} / \mathrm{Kg})$; 2) Met (200 mg/Kg); 3) Ox (15 mg/Kg); 4) Dox/Met (1 $\mathrm{mg} / \mathrm{Kg} / 200 \mathrm{mg} / \mathrm{kg}$ ); 5) Dox/Ox (1 mg/Kg/15 $\mathrm{mg} / \mathrm{Kg})$; 6) Met/Ox (200 mg/Kg/15 mg/Kg); and 7) Dox/Met/Ox (1/200/15 mg/Kg). All animals were humanely euthanized. At the end of the model development, a representative sample of three animals from group seven was kept for three months for disease recurrence monitoring.

\section{(18F)-FDG micro PET}

Micro PET imaging was performed at Faculty of Medicine, National Autonomous University of Mexico (UNAM), by using the Micro PET Focus 120 Concorde Microsystem, Siemens equipment and the OSEM 3D Siemens software. This technique was employed to follow disease progress in the animal model. Briefly, mice were anesthetized with an isoflurane/oxygen $(0.5 \mathrm{~L} / \mathrm{min})$ induction chamber during $5 \mathrm{~min} ; 200 \mu \mathrm{L}$ of $\left({ }^{18} \mathrm{~F}\right)-\mathrm{FDG}$ were injected via caudal vein, with a bio-distribution time of $45 \mathrm{~min}$; static images were acquired during $30 \mathrm{~min}$. Micro PET images were taken on three different occasions: 1 ) basal state before treatment started, 2) in the middle of the treatment, and 3) at the end of treatment.

\section{Primary Culture}

A primary culture was grown from tumors of the xenograft. Cultures were maintained in RPMI-1640 medium supplemented with SFB 10\% under incubation conditions and treated with Dox, Ox or Met and their combinations during 4, 8, 12 and $24 \mathrm{~h}$, keeping the same concentrations used in the others in vitro experiments. These cells were harvested for Western blotting and qRT-PCR assays.

\section{qRT-PCR}

Total RNA was purified from MDA-MB-231 cell 
line using RNeasy Mini Kit (Qiagen, Valencia, CA). The quality and concentration of RNA in samples was determined using gel electrophoresis and Epoch Microplate Spectrophotometer (Bio-Tek). $500 \mathrm{ng}$ from the different treatments conditions were used for cDNA synthesis using iScript cDNA synthesis kit (Bio-Rad Laboratories, Hercules, CA), according to the manufacturer's instructions. The LDH-A primer set employed to analyze gene expression levels was designed by an experimentally verified computer algorithm, and tested in a quality control assay to guarantee a yield of a single band of $165 \mathrm{bp}$ by agarose gel electrophoresis. The sequence of primers was as follows: forward 5' TTGCAACCGCTTCC ATAACACGG 3' and reverse 3' TGGTCCAGCGTAA CGTGAACATCT 5'. Real-time PCR was performed using FastStart SYBR Green master. In Light Cycler 480 instrument II (Roche, Mannheim, Germany) according to manufacturer's protocol. Triplicate RT samples were utilized in each assay; data were normalized with $\mathrm{B}$-actin housekeeping gene and in a parallel way was used GAPDH. The comparative $\mathrm{Ct}$ method $(\Delta \Delta \mathrm{Ct})$ was employed to quantify gene expression, and the relative quantification was calculated as $2^{-\Delta \Delta C t}$.

\section{Western blotting}

After pharmacological treatments, total protein from primary cultured cells was extracted using RIPA buffer (Santa Cruz Biotechnology sc-24948). From these extracts, $50 \mu \mathrm{g}$ of protein were separated by SDS-polyacrylamide gel electrophoresis and transferred to a polyvinylidene difluoride (PVDF) membrane (GE Healthcare, USA) in a semi-dry chamber Trans Blot Turbo (Bio-Rad) at $25 \mathrm{~V} 1 \mathrm{~mA}$ for $30 \mathrm{~min}$. After blocking with $5 \%$ of non-fat milk for $2 \mathrm{~h}$, the membrane was incubated with the specific antibody overnight at $4^{\circ} \mathrm{C}$ on a rocking platform, washed, and then incubated with the corresponding secondary antibody for $2 \mathrm{~h}$ at room temperature. The blot was visualized using the SuperSignal West Femto chemiluminescent substrate (Pierce) in a C-Digit scanner $(\mathrm{LI}-\mathrm{COR})^{\mathrm{TM}}$ employing the IMAGE STUDIO (LI-COR) software.

The primary antibodies for apoptosis were purchased from Santa Cruz Biotechnology (Santa Cruz, CA): anti-PARP-1 (1:3000, sc-8007) and anti-Caspase-3 (H2777) (1:3000, sc-7148). Antibodies for autophagy: anti-LC3 from Cell Signaling Technology (1:2000, \#2775), mTOR (1:3000, Cat. 2983), Phosphorylated-mTOR from Invitrogen (1:3000, Cat. 2971); and, for glycolysis anti-LDH-A (1:1000, sc-27230) from Santa Cruz Biotechnology. All secondary antibodies were obtained from Santa Cruz Biotechnology: anti-mouse (1:5000, sc-23719), anti-rabbit (1:5000, sc-2370) and anti-goat (1:3000, sc-2020). The positive control for apoptosis was UV (10 min of exposure). $\beta$-actin (1:3000, Santa Cruz Biotechnology sc-4778) was used as an internal control.

\section{Statistics}

All experiments were carried out in triplicate unless mentioned. Differences among treatments were evaluated by ANOVA using the Dunnett method for multiple comparisons. For all statistical analyzes, we used the GraphPad PRISM version 5.0 software with an acceptable significance of $p<0.05$.

\section{Results}

\section{Cytotoxic effect of the DoxMetOx therapy in the MDA-MB-231 cells}

MDA-MB-231 cells were treated with Met, Ox, or Dox, or all possible combinations as described in Materials and Methods. The IC $_{50}$ 's were obtained by the SRB assay. The $\mathrm{IC}_{50}$ values for single drugs were of rapid achievement $(4 \mathrm{~h})$ and were also stable along time (maintaining the same effect from 4 to $48 \mathrm{~h}$ ). Figure 1A-C displays IC $_{50}$ values (Dox $0.5 \mu \mathrm{M}$, Met 25 $\mathrm{mM}$, and Ox $15 \mathrm{mM})$. As depicted in Figure 1D, DoxMetOx keeps the same $\mathrm{IC}_{50}$ values as for monotherapy and respect rules of persistent-time-action and initiating point. Even more, the $\mathrm{IC}_{50}$ values when tested as duplets, the concentrations stayed the same (data not shown). The $\mathrm{IC}_{50}$ values used were the same in all in vitro studies.

\section{DoxMetOx reduced tumor growth in vivo tracked by ( ${ }^{18}$ F) FDG micro PET}

Progression of disease and response to treatment was monitored by micro PET image acquisition employing $\left({ }^{18} \mathrm{~F}\right)$-FDG as a metabolic radionuclide tracer as described in material and methods, following the timetable illustrated in Figure 2A. In Figure 2B-D, are shown the last images of the evolution of tumor growth after treatments. The 18F-deoxiglucose accumulates in the brain, heart and bladder, zones of the body that are in bright red in the image. Tumor cells, due to their high proliferation rate, have a greater intake of deoxyglucose, thus coloring the tumor in red as occur in the other organs. As it can be noticed in Figure 2D when tumors treated with DoxMetOx, there is no deoxyglucose intake in the area where the MDA-MB-231 cells were transplanted. All pictures were taken from a representative sample of each group.

The tumors were measured daily to generate a graph of the tumor response to treatments. As depicted in Figure 2E and 2F, monotherapies had no significant reduction in tumor size except for Dox 
$\left({ }^{*} p=0.05\right)$. Also, none of the duplets tested (Met/Ox, Dox/Ox, or Met/Dox) enhanced the effect of Dox alone. On the contrary, when tumors treated with DoxMetOx they stop growing in $48 \mathrm{~h}$, maintaining the same volume until day eight, to finally lead to an absence of measurable tumor mass $\left({ }^{*} \mathrm{p}=0.05\right)$. Furthermore, in a gross external examination, the animals that belonged to DoxMetOx did not experiment toxic effects during the treatment, and moreover, three animals were kept in the vivarium for five months and no disease recurrence was observed.

\section{Activation of Apoptosis by DoxMetOx treatment}

To evaluate apoptosis cell death in MDA-MB-231 cells by the different treatments, we next carried out an assay of Western blot using PARP-1 and caspase 3 as apoptosis markers. When drugs were administrated as monotherapy (Figure 3A-C), both, Dox and Ox, slightly increased the expression of the full-length procaspase 3 or cleavage of PARP-1 in comparison to Met, who presented a major expression of both proteins and in shorter times. Single treatments had a time-dependent pro-apoptotic effect. Whereas the DoxMetOx therapy showed a substantial

A
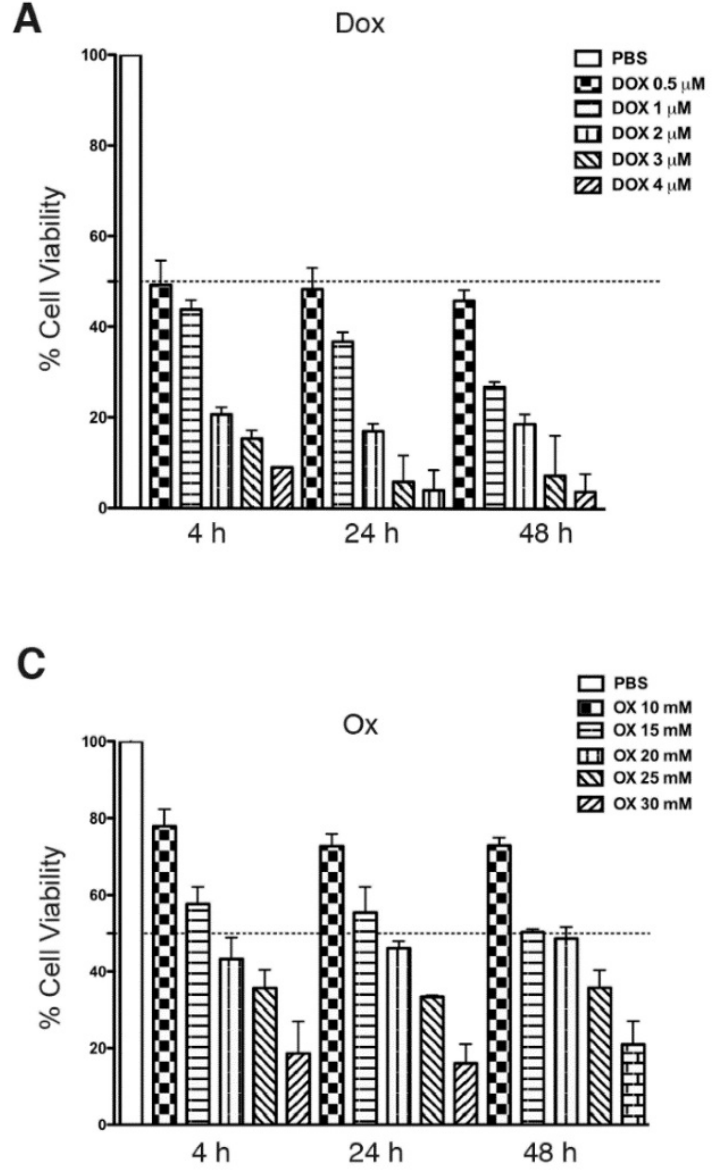

up-regulation of cleaved PARP-1 from the $4 \mathrm{~h}$ time point, which corresponds to the detection of cleaved effector caspase 3, maintaining the effect along tested times. The duplet Met/Ox had similar result since 12 $\mathrm{h}$ with cleaved PARP-1.

Western blot results, proved the induction of apoptosis in MDA-MB-231 breast cancer cell line by DoxMetOx, by both caspase-dependent and PARP-dependent apoptosis cell death, enhancing the Met proapoptotic activity

Moreover, the annexin $\mathrm{V}$ assays provided support for the pro-apoptotic effect of the combination DoxMetOx. As depicted in Figure 3F, when the three drugs are together, after $48 \mathrm{~h}$ of treatment $87 \%$ of the cells enter into apoptosis, effect that remains for $72 \mathrm{~h}$. In comparison, when cells are treated with the drugs individually, doxorubicin is highly toxic after $72 \mathrm{~h}$ (Figure 3F). On the other side, metformin and oxamate are less aggressive but also time-dependent (Figure 3F). Metformin and Oxamate after $48 \mathrm{~h}$ induced early apoptosis in $31 \%$ and $11 \%$, respectively. Interestingly, the proapoptotic effect of the oxamate increases in time to $47 \%$ (Figure $3 \mathrm{~F}$ ).
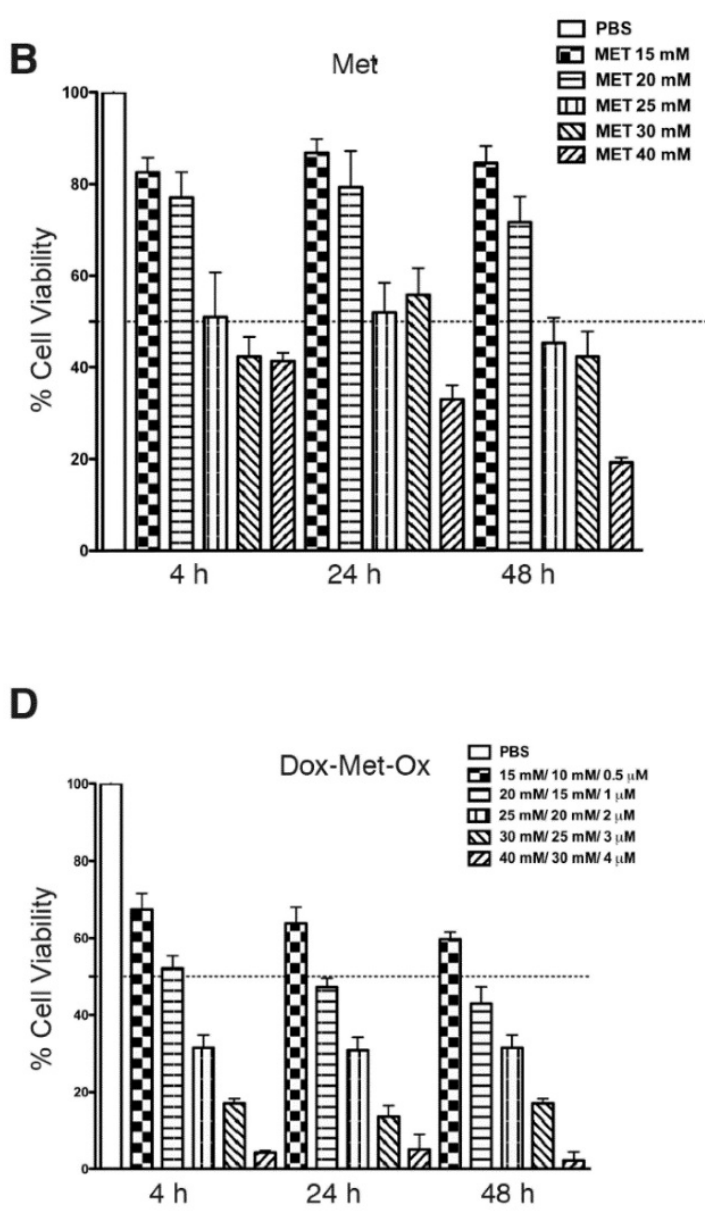

Figure 1. Cytotoxic effect of Metformin, Oxamate or Doxorubicin, and their combinations against MDA-MB-231 cells in the SRB assay. MDA-MB-231 cells were treated with Met, Ox, or Dox alone, and all possible combinations for 4, 24, 48 and 72 hours at different concentrations. Estimated IC 50 values are Dox $0.5 \mu$ M, Met $25 \mathrm{mM}$, and Ox $15 \mathrm{mM}$. 
A
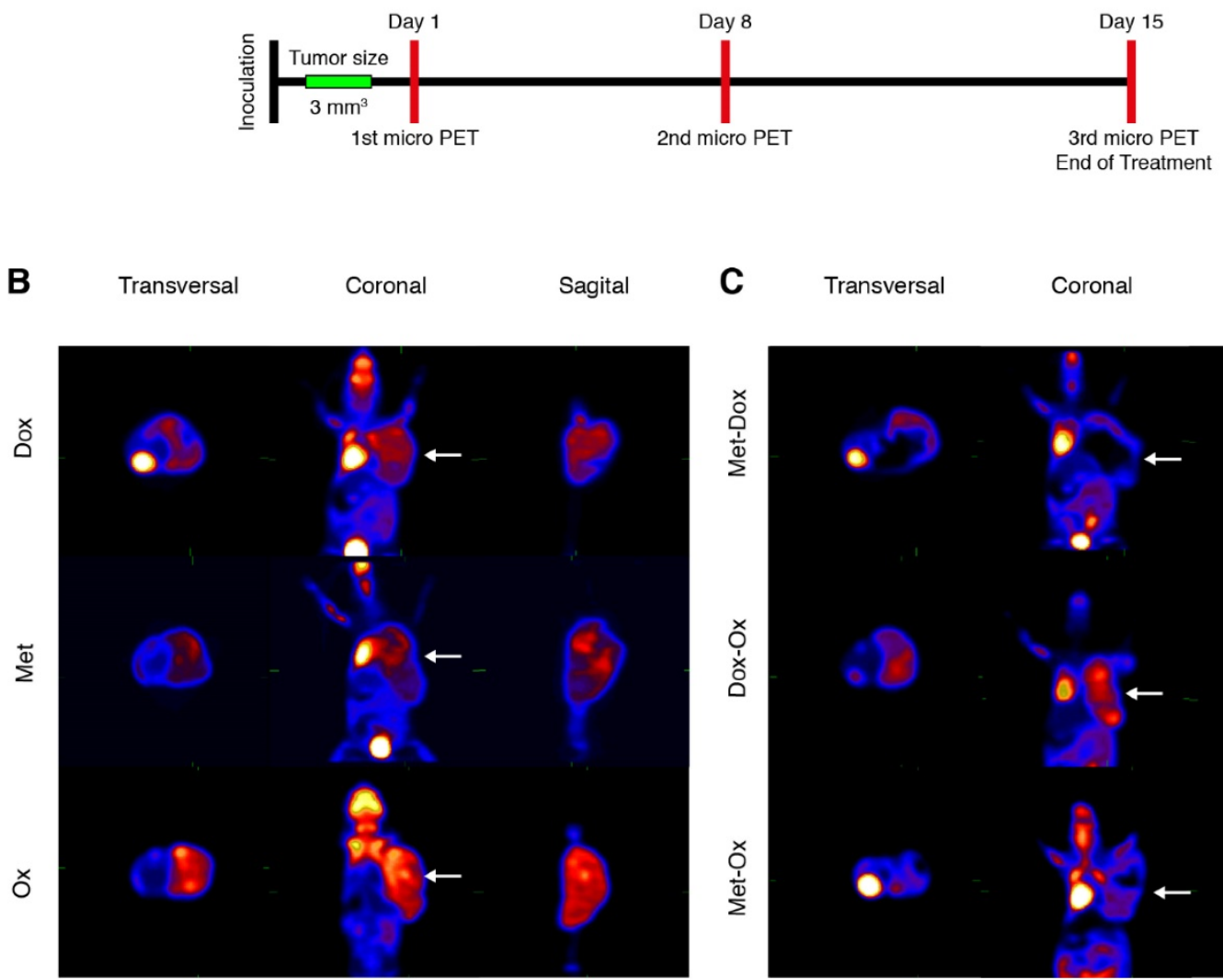

C Transversal Coronal Sagital

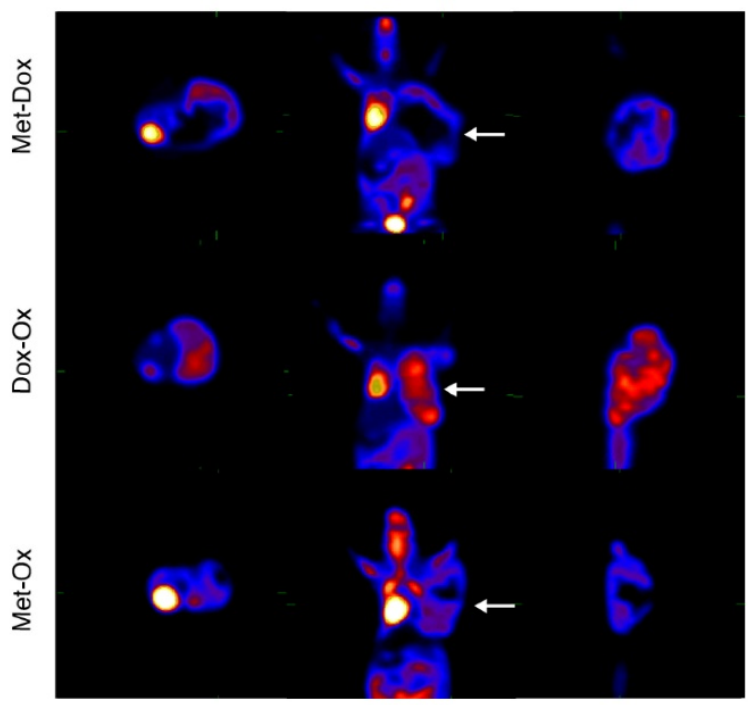

D Transversal Coronal Sagital

E

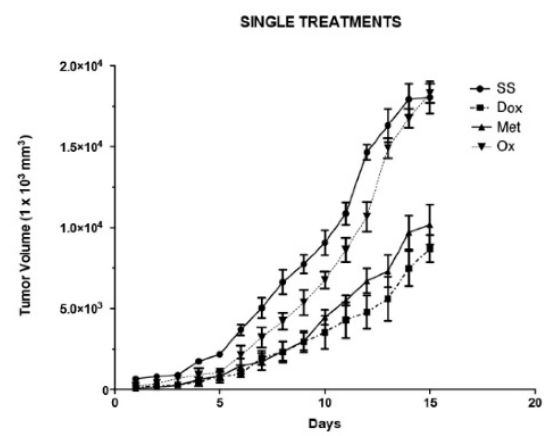

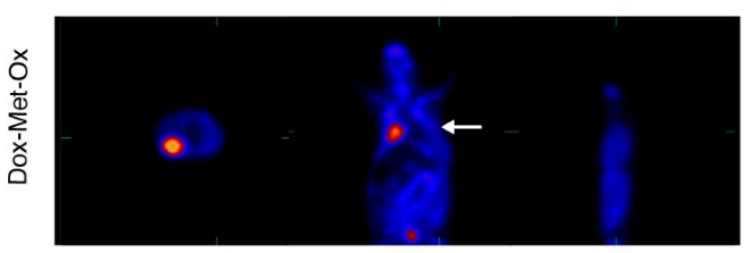

$\mathbf{F}$

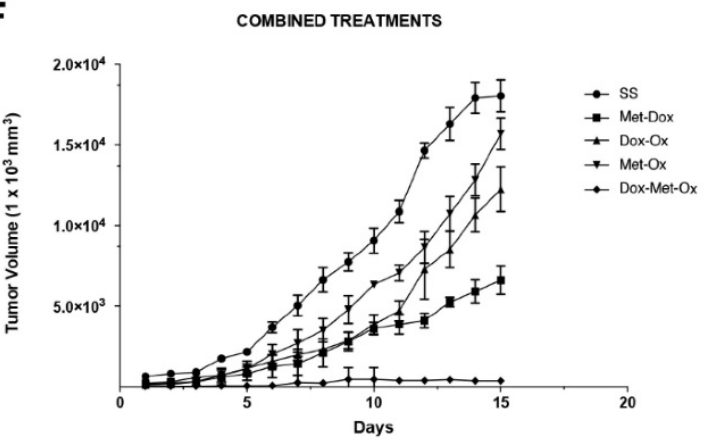

Figure 2. Tumor growth of MDA-MB-23I xenotransplant in nude mice after different treatments. A) The schedule followed for drug administration and microPET monitoring. B-D) Results of the third micro PET imaging acquisition. The disease progression was monitored by the molecular imaging technique micro PET using the radionuclide (18F)FDG on three different occasions: basal state, day eight and day 15 (end of treatment). The acquisitions were performed in transverse and coronal cuts. Animals were euthanized at the end of the treatments. B) Monotherapies: Dox, Met, and Ox; C) Duplets: Met/Dox; Dox/Ox and Met/Ox; and D) DoxMetOx (*p<0.05). In all cases were used the same doses: Dox $1 \mathrm{mg} / \mathrm{Kg}$, Met $200 \mathrm{mg} / \mathrm{Kg}$, and Ox $15 \mathrm{mg} / \mathrm{Kg}$. The ( $\left.{ }^{18} \mathrm{~F}\right) \mathrm{FDG}$ is accumulated in the brain, heart and bladder, colored in bright red in the picture. Tumors are also colored in red in the right flank of the animals. The DoxMetOx group showed a complete remission of the tumor mass at the end of treatment, no presence of the radionuclide accumulation or disease recurrence were detected. Assays were performed at least on three independent occasions with three animals in each experiment. E) Nude mice were inoculated with $10 \times 10^{6}$ MDA-MB-231 cells on the right flank. Once the tumor reached a volume of $50 \mathrm{~mm}^{3}$, treatments started. Drugs were administered daily via i.p. for 15 days and tumor masses were measured and graphed \pm S.E. The response of the animals to monotherapies Doxorubicin $(1 \mathrm{mg} / \mathrm{Kg})(\mathrm{p}=0.05)$, Metformin $(200 \mathrm{mg} / \mathrm{Kg})$ and Oxamate $(15 \mathrm{mg} / \mathrm{Kg}$ ). F) Effect of duplets (Dox/Met; Dox/Ox; Met/Ox) and DoxMetOx against tumors. DoxMetOx reduced tumor mass growth (*p<0.005) in comparison to the other possible drugs' combinations. 
A

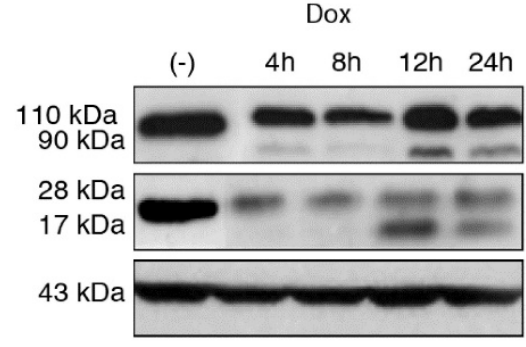

D
B

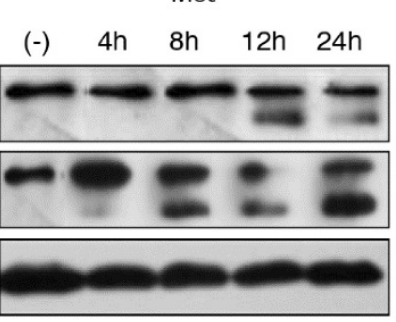

C

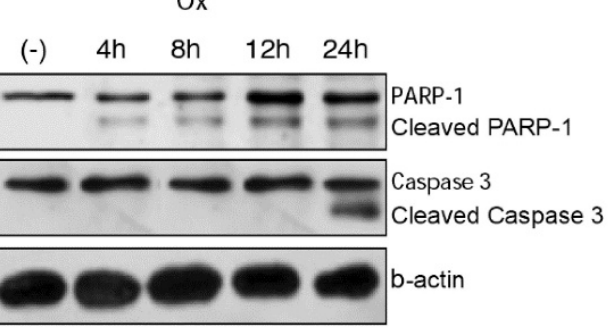

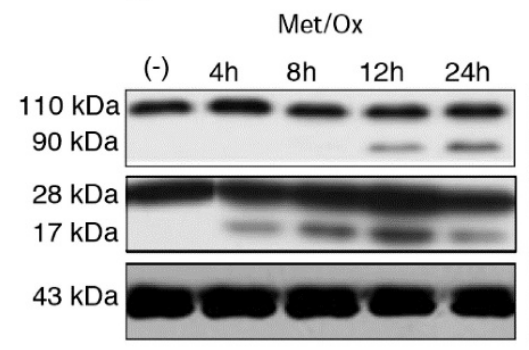

E

\author{
Dox/Met/Ox
}

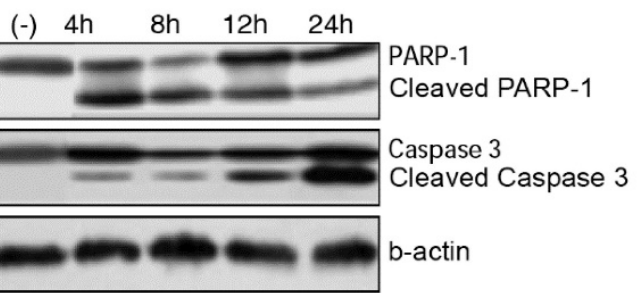

$\mathrm{F}$
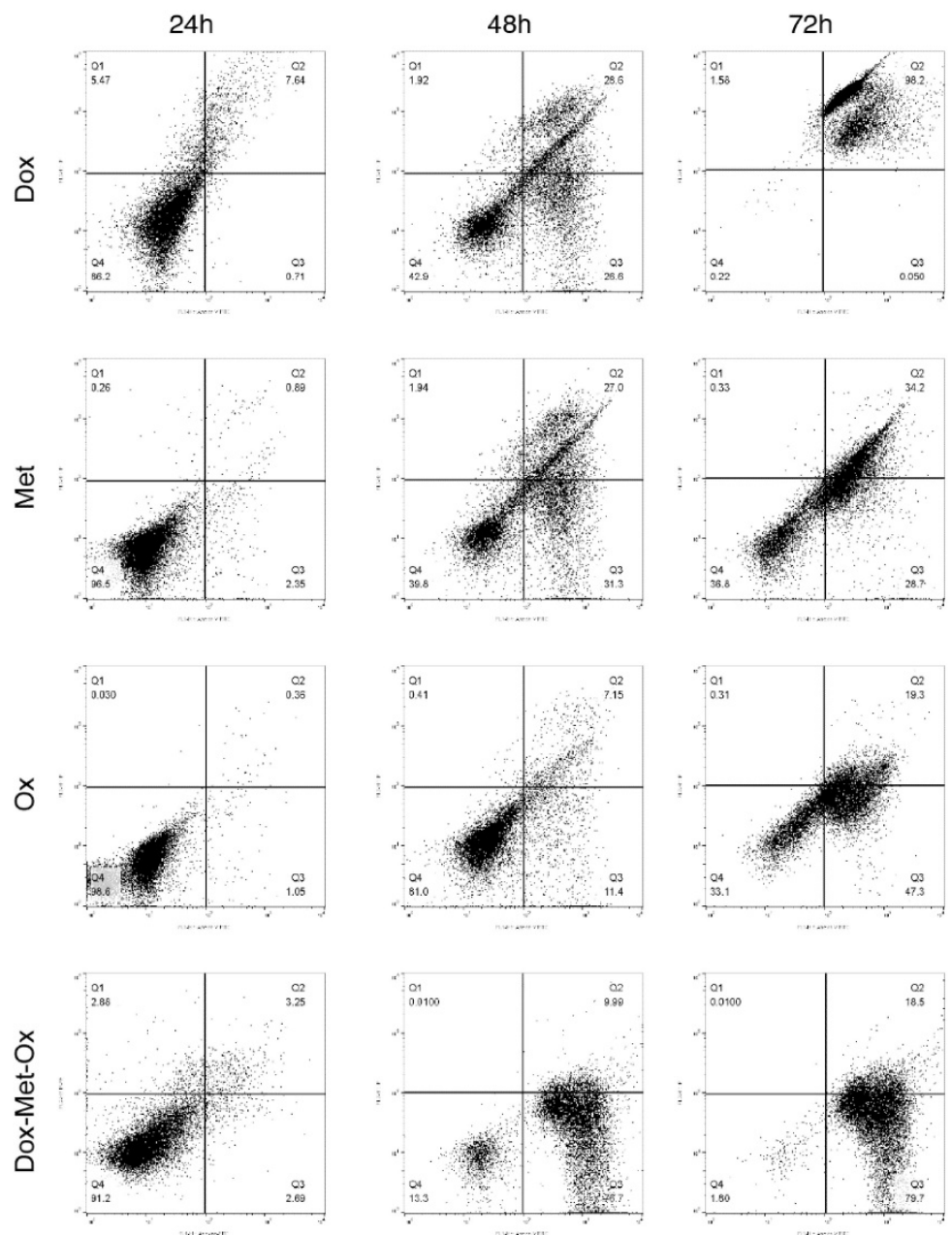

Figure 3. Apoptosis activated by DoxMetOx. A) Apoptosis induction identified by Western blot detection of PARP-1 and caspase 3. We searched for the effect of tested drugs or combinations at short times. As can be clearly observed (E) DoxMetOx could activate both, PARP-1 and caspase 3 at $4 \mathrm{~h}$ point time, as a continuous process along 24 hours. F) Finally, to corroborate our results we assayed apoptosis by means of flow cytometry after staining with Annexin V-FITC/propidium iodide. As can be observed in representative scatter plots of $\mathrm{PI}$ (y-axis) vs. Annexin $\mathrm{V}$ (x-axis), DoxMetOx therapy induced early apoptosis (lower right quadrant) since $48 \mathrm{~h}$ and at $72 \mathrm{~h}$ the induction of apoptosis was in $99 \%$ of tumoral cells. 


\section{DoxMetOx is likely to induce autophagy through LC3 protein activation and $m$ TOR inhibition}

The induction of autophagy was evaluated through LC3 protein activation and inhibition of phosphorylated-mTOR (p-mTOR) by Western Blotting (Figure 4A-E). As single treatments, Met and Ox moderately favored the inhibition of $\mathrm{p}$-mTOR and increased LC3-II accumulation (Figure 4B and C); on the contrary, such effect was not observed with Dox, which unexpectedly increased the p-mTOR signal (Figure 4A). The duplet Met-Ox inhibited p-mTOR after $12 \mathrm{~h}$ of treatment, and it does fairly increment the conversion of LC3-I to LC3-II (Figure 4D). In contrast, DoxMetOx promotes the inhibition of phosphorylated mTOR and a significant increment in the conversion of LC3-I to LC3-II at $4 \mathrm{~h}$ (Figure 4E). These data suggest that the DoxMetOx therapy could also induce tumor cell autophagy in early stages even more efficiently than Met alone, which in our results seem to require longer time to inhibit p-mTOR (Figure 4B).

\section{DoxMetOx inhibits LDH-A expression}

RT-PCR and Western blot experiments were performed to assess expression levels of LDH-A as a marker of glycolysis. As depicted in Figure 5, Oxamate -the specific inhibitor of LDH-A- had a time-dependent inhibition response; it could require a longer treatment or a higher concentration since incomplete LDH-A inhibition was observed. Dox did

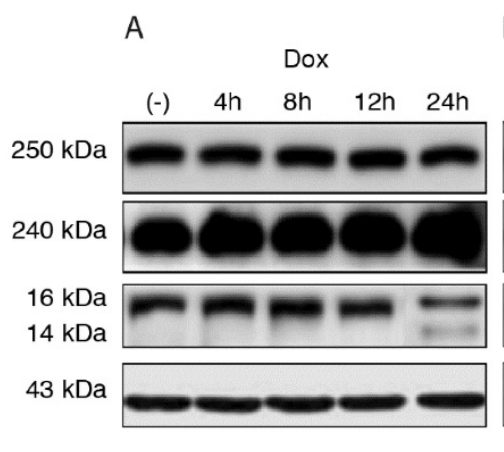

B
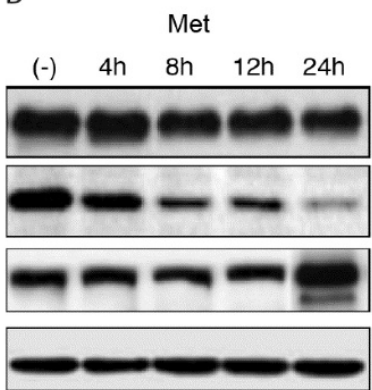

ox

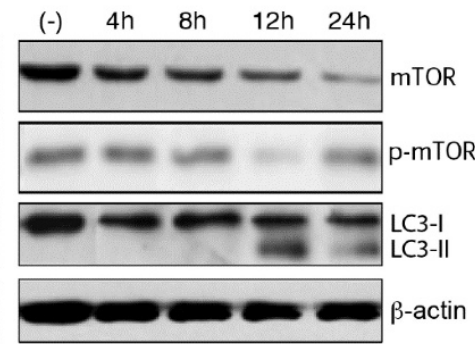

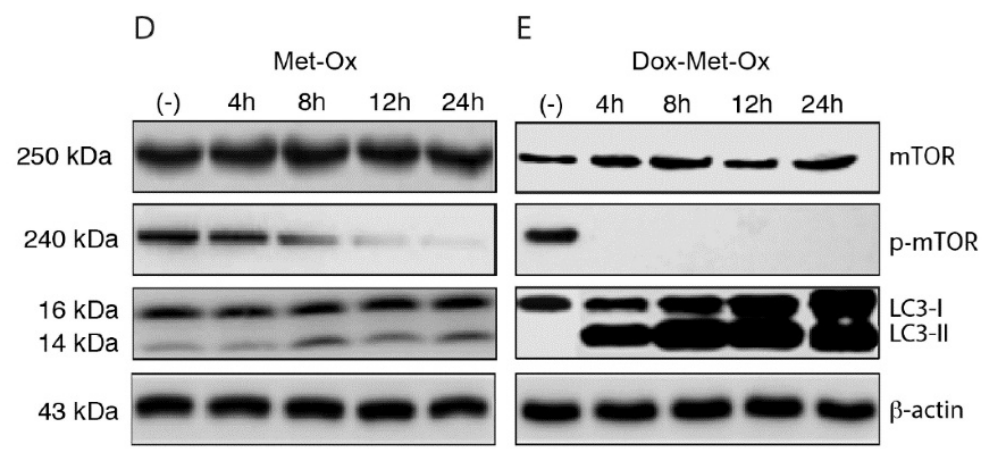

Figure 4. Early autophagy activation and inhibition of p-mTOR. DoxMetOx was able to inhibit p-mTOR at $4 \mathrm{~h}$, and the effect was maintained up to $24 \mathrm{~h}$. The same occurred with LC3-II accumulation, in contrast to monotherapies or duplets. 

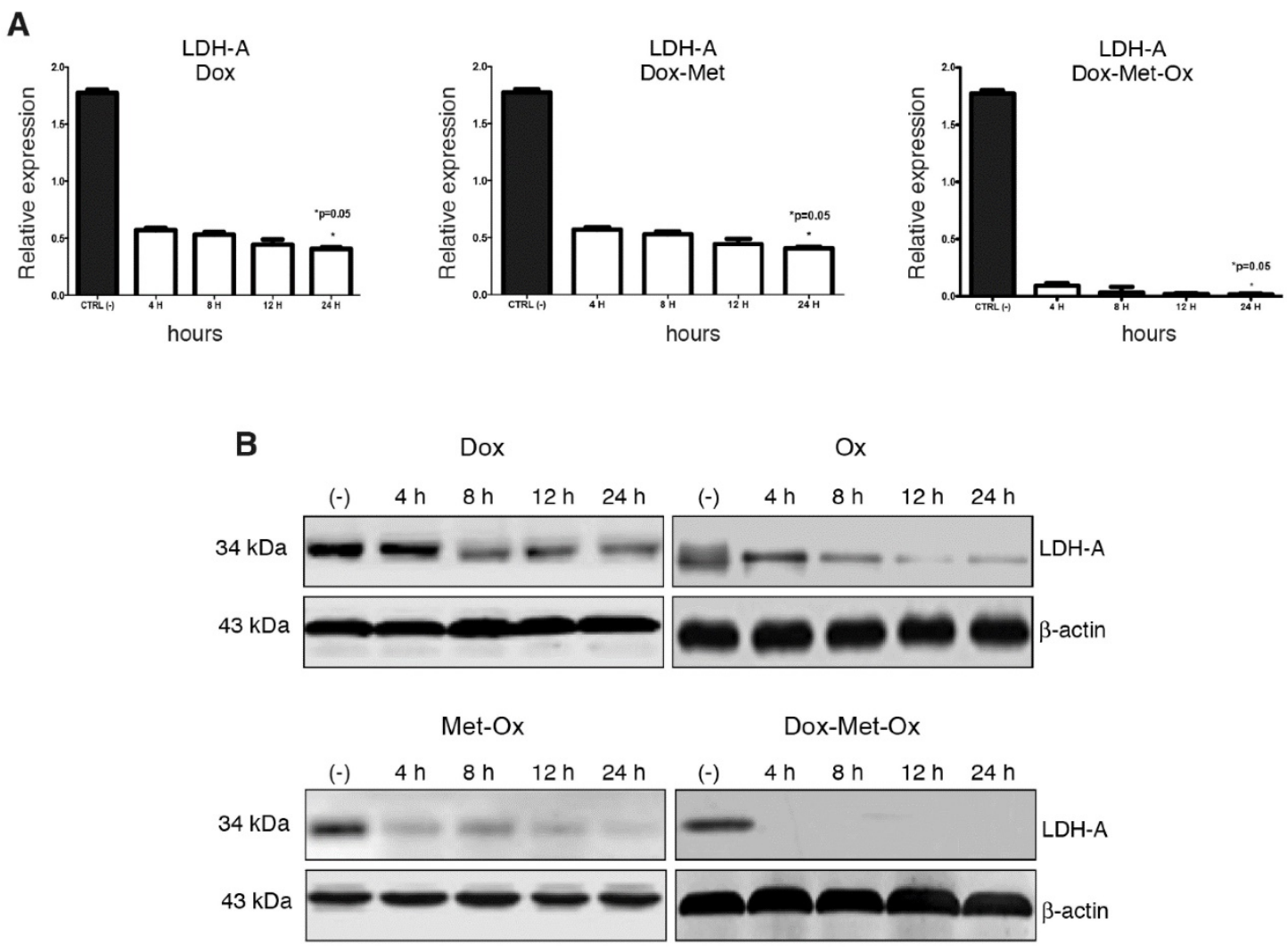

Figure 5. LDH-A inhibition by triple therapy. mRNA and protein levels were analyzed by qRT-PCR and western blot, respectively. A) DoxMetOx inhibited the protein levels of LDH-A. B) mRNA levels were undetectable when DoxMetOx was administered.

Anticancer therapies have been developed through the years, but the deregulation of cellular energetics has been approached less frequently. Our work shows the striking effect of a novel combined therapy comprising Metformin, Oxamate, and Doxorubicin, which target key hallmarks of cancer: nucleic acid synthesis, mTOR and LDH-A inhibition leading to apoptosis and autophagy activation. The experimental group of mice that received DoxMetOx therapy exhibited complete tumor growth suppression and in vitro results showed evidence of enhanced apoptosis and autophagy, which is consistent with an energetic metabolism reprogramming. Metformin is not limited to its function as the preferred drug for diabetes, as it has been demonstrated that it has antineoplastic activity as well. In vitro, the Metformin inhibits cell proliferation (32), and induces caspase- and PARP-dependent apoptotic cell death in several breast cancer cell lines $(26,39)$. In vivo, it has been a successful tumor growth inhibitor in colon, breast, pancreatic, and lung cancers $(25,26,27,40,41,42,43)$. Nevertheless, it is known that its use as an anticancer monotherapy drug is not effective.

Oxamate has been associated with antimetabolic effect, the inhibition of TCA cycle mediator production, and reduction of the glycolytic flux and the electron chain transport activity (17). Moreover, in vivo it has shown tumor growth reduction in two hepatocellular cancer cell lines (44). Additionally, Oxamate significantly arrests lung cells in G0/G1 phase (45), and Metformin induces cell cycle arrest in G1 phase in TNBC cell lines (26). Finally, Doxorubicin is a well-known antineoplastic drug, which is a DNA intercalator that acts as a nucleic acid synthesis inhibitor (46).

The $\mathrm{IC}_{50}$ values obtained for the tested drugs are consistent with values reported somewhere else $(45,47)$, and the doses used in vivo of the three drugs were in the lower end of the recommended clinical dosage range for humans in the case of metformin and doxorubicin (48), and for animals in the event of oxamate (21). Therefore, the doses employed in our work are in agreement with other findings both in vitro and in vivo related to the toxicity range of the drugs.

In the murine model, mice carrying tumors subjected to the DoxMetOx therapy stopped growing after $24 \mathrm{~h}$ of the first drug administration and tumor volume kept stable for six days. Nevertheless, on day 11 tumor mass was complete eradicated, analyzed by both FDG-microPET and tumor volume measure. Indeed, the action of the DoxMetOx therapy was surprisingly fast; in the murine model it took only 24 
$\mathrm{h}$ to stop tumor growth, followed by a complete elimination of the xenograft. Furthermore, animals of the DoxMetOx group were free of disease five months after finishing therapy, which confirms tumor elimination; these animals did not present obvious toxicity signs during the 15 days of the DoxMetOx therapy.

Recently, Miskimins and colleagues (20) published that the combination of oxamate and phenformin, act in synergy inhibiting proliferation in the breast, melanoma, colon, lung and prostate cancer cells. Also, in vivo this drugs combination showed a considerable reduction of the tumor size after 21 days of treatment. They suggested that the phenformin-oxamate combination increases apoptosis through the inhibition of complex $\mathrm{I}$ in the mitochondria by phenformin and simultaneously targeting the LDH in the cytosol by oxamate. Even though phenformin is a chemical analog of metformin, we did not observe any significant inhibition of tumor growth when metformin and oxamate were co-administered in vivo in our study.

According to data presented here, none of the three drugs used as monotherapy favored apoptosis or autophagy (Figures 3A-B and 4A-C). However, when the combination DoxMetOx was tested in vitro, they had an enhanced proapoptotic effect and showed the initiation of autophagy. Our results demonstrated that DoxMetOx leads to apoptosis by two mechanisms, the caspase- and PARP-dependent pathways. Such findings are supported by the flow cytometry results, where DoxMetOx showed a rising effect of apoptosis since the first $48 \mathrm{~h}$ after treatment keeping the same activity until $72 \mathrm{~h}$. It is notable that the combination of the three drugs diminished the cytotoxic effect of the doxorubicin and restored the apoptosis death capacity of cells in short times.

Respecting to LDH-A expression a surprising result was observed, DoxMetOx was capable to inhibit LDH-A completely both at mRNA and protein level; suggesting an inhibition of transcription of the gene; however, more experiments are needed to clarify this point. Such effect was unexpected since neither oxamate as monotherapy nor the duplets that included it, had substantial effects on LDH-A inhibition or apoptosis death, as the previously reported for lung cancer cells (45). The LDH-A enzyme is known to be overexpressed in breast cancer $(49,50)$, and its inhibition blocks aerobic glycolysis in tumor cells without harming normal cells that do not require LDH-A in the presence of oxygen; this protective effect to non-malignant cells could explain the non-toxic effect of the DoxMetOx to the surrounding tissue in the animals or even toxic systemic visible symptoms in nude mice.

The role of autophagy in cancer is part of an important debate. It has been documented that autophagy has a pro-tumorigenic function in the invasion and metastasis processes $(51,52)$. Whereas there is also evidence, that supports tumor suppressor function in early stages through the protein Beclin-1 (53). Our results provide insight into the crosstalk between apoptosis and autophagy generated by anticancer therapies. A key step involved in this event is the inhibition of mTOR, the target of new drugs, which currently are under clinical trials for lung, blood, breast, and kidney cancers (54).

Phosphorylated-mTOR was inhibited in vitro by the DoxMetOx therapy in four hours. At the same time point, the drugs lead to accumulation of LC3-II that is an essential protein in the formation of the phagophore, initial step of autophagy efflux that lately leads to its elongation and closure to form the autophagosome, that when fused with lysosomes initiate the degradation of the different cellular contents in the autophagolysosome (55). Thus, the detection of LC3-II is significant to identify the autophagy process or even autophagic death.

The evidence provided by our group so far suggest that the DoxMetOx therapy kills the tumor cell in a very effective way and in short times $(4 \mathrm{~h})$. However, it is important for further investigation to describe cellular effects within a shorter period to unravel the cellular mechanisms switched on implicated in cell death and tumor mass suppression. In this context, we propose that when drugs are in combination, tumor cells fall into an energetic crisis and, as a consequence, apoptotic death is reactivated, either initiated or followed by autophagy, suggesting that all events are possibly derived mainly from the inhibition of glycolysis via the LDH-A inhibition.

Simultaneously, our research group found that in an associated inflammatory model of colorectal cancer in Balb/c mice, the administration of the combined treatment at the same dose, accomplished a reduction in the number and size of tumors in comparison to Dox used as positive control. These results correspond to our findings in mice carrying tumors of the TNBC cell line MDA-MB-231. Interestingly, after $4 \mathrm{~h}$ of treatment with the DoxMetOx therapy, three biological events were recorded: apoptosis cell death, induction of autophagy, and glycolysis inhibition in both murine models. 


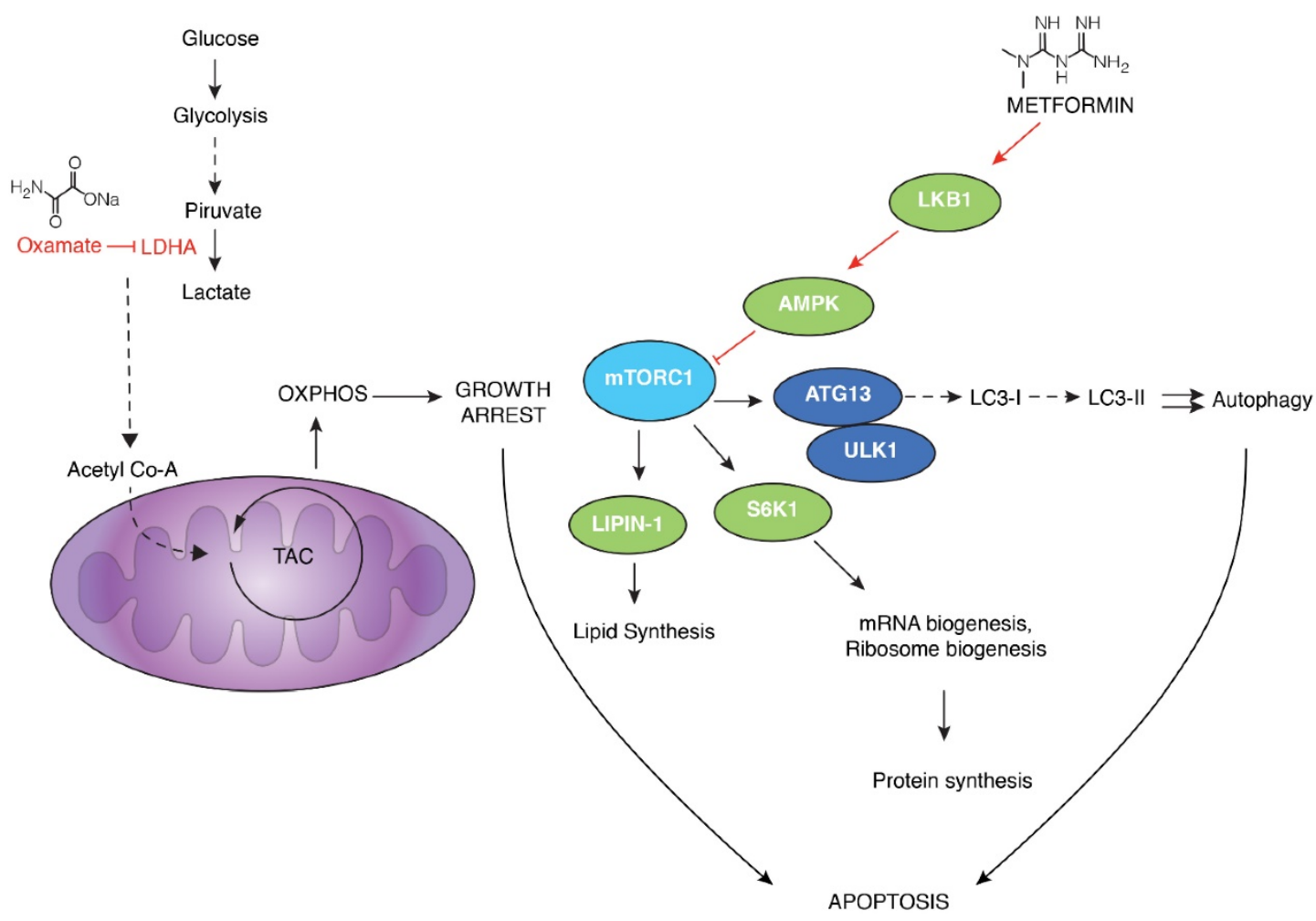

Figure 6. Proposed mechanism of action by the combination of metformin and oxamate treatment in triple negative breast cancer. Sodium oxamate targets lactate dehydrogenase A (LDHA) results in the increase of oxidative phosphorylation which in turn increase oxidative stress and subsequent growth arrest; ensuing inhibition of glycolysis. Metformin induces the activation of LKBI and phosphorylation of AMPK, leading to inactivation of $\mathrm{mTORCl}$ and subsequent biosynthetic pathways such as mRNA biogenesis, ribosome biogenesis, and lipid synthesis, among others. This is a crucial step conducting to concurrent activation of apoptosis, mainly due to activation of autophagy and energy depletion.

\section{Conclusions}

Currently, therapeutic explorations in cancer are focused on disease metabolism considering, on one hand, a specific action on cancer cells, and on the other, procuring no-side effects on normal cells. Understanding the biology and behavior of cancer cells is fundamental towards these aims.

Present work shows a new therapeutic strategy for triple negative breast cancer that dramatically reduced the tumor growth in mice in a short time, where the effectiveness was preserved for five months after finishing the therapy. The chosen drugs seem to act directly on tumor cells by inhibiting glycolysis and mTOR signaling, and activating mechanisms that lead eventually to apoptosis. Moreover, our therapy enriches with molecular evidence, the link between autophagy and apoptosis mechanisms of death. These findings are highly promising for future clinical trials on humans.

\section{Acknowledgments}

This manuscript complies in partial fulfillments author requirements for Ph.D. degree for V.G.-C. at Posgrado en Biología Experimental, Universidad Autónoma Metropolitana (UAM), Mexico. V.G.-C. is grateful to CONACyT for a graduate student scholarship (Grant 307249). We thank M. en C. Mallely C. Ávila-García and M. en C. Victor M. Lara-Camacho (PET Cyclotron Unit, Faculty of Medicine, National Autonomous University) for their help in micro PET assays. Authors are grateful to Dr. Alberto Huberman for his contribution to the improvement of the manuscript.

\section{Authors' contributions}

JHNJ and PPC conceived and designed the study. VSO performed and coordinated the mouse xenograft study. GCV and LUE performed the cytotoxicity evaluation, Western blots, and RT-PCR assays. GCV and ARMA performed the microPET imaging acquisition. LUE participated in the data analysis and figures editing. ZDA contributed to the discussion and data analysis. JHNJ and PPS carried out the literature search and wrote the manuscript. All authors read and approved the final manuscript.

\section{Competing interests} interests.

The authors declare that they have no competing

\section{References}

1. Jemal A, Bray F, Center MM, Ferlay J, Ward E, Forman D. Global Cancer Statistis. CA Cancer J Clin. 2011;61:69-90. 
2. Ferlay J, Soerjomataram I, Ervik M, Dikshit R,Eser S, Mathers C, Rebelo M, Parkin DM, Forman D, Bray F. GLOBOCAN 2012 v1.0, Cancer Incidence and Mortality Worldwide: IARC CancerBase No. 11 (Internet).

3. Irvin WJ, Carey LA. What is triple negative breast cancer? Eur J Cancer. 2008;44:2799-2805.

4. Dent R, Trudeau M, Pritchard KI, Hanna WM, Kahn HK, Sawka CA, Lickley LA, Rawlinson E, Sun P, Narod SA. Triple negative breast cancer: clinical features and patterns of recurrence. Clin Cancer Res. 2007;13:4429-4434.

5. Lara-Medina, F, Pérez-Sánchez V, Saavedra-Pérez D, Blake-Cerda M, Arce C, Motola-Kuba D, Villarreal-Garza C, González-Angulo AM, Bargalló E, Aguilar JL, Mohar A, Arrieta O. Triple-Negative Breast Cancer in Hispanic Patients. Cancer. 2011;3658-3669.

6. Cárdenas-Sánchez J, Bargalló-Rocha E, Erazo-Valle A, Maafs-Molina E, Poitevin-Chacón A. Consenso Mexicano sobre diagnóstico y tratamiento del cáncer mamario. 5th Edition. Elsevier. 2013; 125. http://consensocancermamario.com

7. Warburg O. On the origin of cancer cells. Science. 1956;123(3191):309-314

8. Pelicano, H, Martin DS, Xu R-H, Huang P. Glycolysis inhibition for anticancer treatment. Oncogene. 2006;25:4633-4646.

9. Miao P, Sheng S, Sun X, Liu J, Huang G. Lactate dehydrogenase A in cancer: a promising target for diagnosis and therapy. IUBMB Life. 2013;65:904-910.

10. Lee GH, Yan C, Shin SJ, Hong SC, Ahn T, Moon A, Park SJ, Lee YC, Yoo WH, Kim HT, Kim DS, Chae SW, Kim HR, Chae HJ. BAX inhibitor-1 enhances cancer metastasis by altering glucose metabolism and activating the sodium-hydrogen exchanger: the alteration of mitochondrial function. Oncogene. 2010;29(14):2130-41.

11. Gottfried E, Kunz-Schughart LA, Ebner S, Mueller-Klieser W, Hoves S, Andreesen R, Mackensen A, Kreutz M. Tumor-derived lactic acid modulates dendritic cell activation and antigen expression. Blood. 2006;107(5):2013-2021.

12. Avena P, Anselmo W, Wang Ch, Pestell RG, Lamb RS, Casaburi I, Andò S, Martinez-Outschoorn UE, Lisanti MP. Compartment-specific activation of PPARY governs breast cancer tumor growth, via metabolic reprogramming and symbiosis. Cell Cycle. 2013;12(9):1360-70.

13. Walenta S, Wetterling M, Lehrke M, Schwickert G, Sundfør K, Rofstad EK, Mueller-Klieser W. High lactate levels predict likelihood of metastases, tumor recurrence, and restricted patient survival in human cervical cancers. Cancer Res. 2000;60(4):916-921.

14. Brizel DM, Schroeder T, Scher RL, Walenta S, Clough RW, Dewhirst MW, Mueller-Klieser W. Elevated tumor lactate concentrations predict for an increased risk of metastases in head-and-neck cancer. Int J Radiat Oncol Biol Phys. 2001;51(2):349-353.

15. Beckner ME, Stracke ML, Liotta LA, Schiffmann E. Glycolysis as primary energy source in tumor cell chemotaxis. J Natl Cancer Inst. 1990;82(23):1836-1840

16. Liu H, Hu YP, Savaraj N, Priebe W, Lampidis TJ. Hypersensitization of tumor cells to glycolytic inhibitors. Biochemistry. 2001;40(18):5542-5547.

17. Liu H, Savaraj N, Priebe W, Lampidis TJ. Hypoxia increases tumor cell sensitivity to glycolytic inhibitors: a strategy for solid tumor therapy (Model C). Biochem Pharmacol. 2002;64(12):1745-1751.

18. Thornburg JM, Nelson KK, Clem BF, Lane AN, Arumugam S, Simmons A, Eaton JW, Telang S, Chesney J. Targeting aspartate aminotransferase in breast cancer. Breast Cancer Res. 2008;10(5):R84.

19. Zhao YH, Zhou M, Liu H, Ding Y, Khong HT, Yu D, Fodstad O, Tan M. Upregulation of lactate dehydrogenase A by ErbB2 through heat shock factor 1 promotes breast cancer cell glycolysis and growth. Oncogene. 2009;28(42):3689-3701.

20. Miskimins WK, Ahn HJ, Kim JY, Ryu S, Jung Y-S, Choi JY. Synergistic anti-cancer effect of phenformin and oxamate. Plos One. 2014;9(1):e85576.

21. Papaconstantinou J, Colowick SP. The role of glycolysis in the growth of tumor cells. II. The effect of oxamic acid on the growth of HeLa cells in tissue culture. J Biol Chem. 1961;236:285-288.

22. Fantin VR, St-Pierre J, Leder P. Attenuation of LDH-A expression uncovers a link between glycolysis, mitochondrial physiology, and tumor maintenance. Cancer Cell. 2006;9:425-434

23. Xie H, Valera VA, Merino MJ, Amato AM, Signoretti S, Linehan WM, Sukhatme VP, Seth P. LDH-A inhibition, a therapeutic strategy for treatment of hereditary leiomyomatosis and renal cell cancer. Mol Cancer Ther. 2009;8:626-635.

24. Libby G, Donnelly LA, Donnan PT, Alessi DR, Morris AD, Evans JM. New users of metformin are at low risk of incident cancer: a cohort study among people with type 2 diabetes. Diabetes Care. 2009;32(9):1620-1625.

25. Ben Sahra I, Laurent K, Loubat A, Giorgetti-Peraldi S, Colosetti P, Auberger P, Tanti JF, Le Marchand-Brustel Y, Bost F. Antidiabetic drug metformin exerts an antitumor effect in vitro and in vivo through a decrease of cyclin D1 level. Oncogene 2008;27:3576-86.

26. Liu B, Fan Z, Edgerton SM, Deng XS, Alimova IN, Lind SE, Thor AD. Metformin induces unique biological and molecular responses in triple negative breast cancer cells. Cell Cycle. 2009;8:2031-2040.

27. Hirsch HA, Iliopoulos D, Tsichlis PN, Struhl K. Metformin selectively targets cancer stem cells, and acts together with chemotherapy to block tumor growth and prolong remission. Cancer Res. 2009;69:7507-7511.

28. Kato K, Gong J, Iwama H, Kitanaka A, Tani J, Miyoshi H, Nomura K, Mimura S, Kobayashi M, Aritomo Y, Kobara H, Mori H, Himoto T, Okano K, Suzuki Y, Murao K, Masaki T. The antidiabetic drug metformin inhibits gastric cancer cell proliferation in vitro and in vivo. Mol Cancer Ther. 2012;11(3):549-560.
29. Hardie DG. Role of AMP-activated protein kinase in the metabolic syndrome and in heart disease. FEBS Lett. 2008;582(1):81-89.

30. Poels J, Spasic MR, Callaerts P, Norga KK. Expanding roles for AMP-activated protein kinase in neuronal survival and autophagy. Bioessays. 2009;31(9): 944-952.

31. Shackelford DB, Shaw RJ. The LKB1-AMPK pathway: metabolism and growth control in tumour suppression. Nat Rev Cancer. 2009:9(8):563-575.

32. González-Angulo, AM, and Meric-Bernstam, F. Metformin: a therapeutic opportunity in breast cancer. Clin Cancer Res. 2010;16(6):1695-1700.

33. Vichai V, Kirtikara K. Sulforhodamine B colorimetric assay for cytotoxicity screening. Nat Protoc. 2006;1(3):1112-1116.

34. Hedley BJ, Chu JE, Ormond DG, Beausoleil MS, Boasie A, Alan AL, Xeno Costas A. Recombinant human erythropoietin in combination with chemotherapy increases breast cancer metastasis in preclinical models. Clin Cancer Res. 2011;17(19):6151-6162.

35. Couch FJ, Hart SN, Sharma P, Toland AE, Wang X, Miron P, Olson JE, Godwin AK, Pankratz VS, Olswold C, Slettedahl S, Halberg E, Guidugli L, Davila JI, Beckmann MW, Janni W, Rack B, Ekici AB, Slamon DJ, Konstantopoulou I, Fostira F, Vratimos A, Fountzilas G, Pelttari LM, Tapper WJ, Durcan L, Cross SS, Pilarski R, Shapiro CL, Kemp J, Yao S, Garber J, Cox A, Brauch H, Ambrosone C, Nevanlinna H, Yannoukakos D, Slager SL, Vachon CM, Eccles DM, Fasching PA. Inherited mutations in 17 breast cancer susceptibility genes among a large triple-negative breast cancer cohort unselected for family history of breast cancer. J Clin Oncol. 2015;33(4):304-311.

36. Bernier J, Poortmans PMP. Surgery and radiation therapy of triple-negative breast cancers: from biology to clinics. Breast. 2016;28:148-155.

37. Reddy KB. Triple-negative breast cancer: an updated review on treatment options. Current Oncology 2011;18(4):e173-e179.

38. Baselga J. Why the epidermal growth factor receptor? The rationale for cancer therapy. Oncologist; 2002;7(suppl 4):2-8

39. Anisimov VN, Berstein LM, Egormin PA, Piskunova TS, Popovich IG, Zabezhinski MA, Kovalenko IG, Poroshina TE, Semenchenko AV, Provinciali M, Re F, Franceschi C. Effect of metformin on life span and on the development of spontaneous mammary tumors in HER-2/neu transgenic mice. Exp Gerontol. 2005;40:685-693.

40. Buzzai M, Jones RG, Amaravadi RK, Lum JJ, DeBerardinis RJ, Zhao F, Viollet $B$, Thompson CB. Systemic treatment with the antidiabetic drug metformin selectively impairs p53-deficient tumor cell growth. Cancer Res. 2007;67:6745-6752.

41. Algire C, Zakikhani M, Blouin MJ, Shuai JH, Pollak M. Metformin attenuates the stimulatory effect of a high-energy diet on in vivo LLC1 carcinoma growth. Endocr Relat Cancer. 2008;15:833-839.

42. Kisfalvi K, Eibl G, Sinnett-Smith J, Rozengurt E. Metformin disrupts crosstalk between $\mathrm{G}$ protein-coupled receptor and insulin receptor signaling systems and inhibits pancreatic cancer growth. Cancer Res. 2009;69:6539-6545.

43. Ward RA, Brassington C, Breeze AL, Caputo A, Critchlow S, Davies G, Goodwin L, Hassall G, Greenwood R, Holdgate GA, Mrosek M, Norman RA, Pearson S, Tart J, Tucker JA, Vogtherr M, Whittaker D, Wingfield J, Winter J, Hudson K. Design and synthesis of novel lactate dehydrogenase A inhibitors by fragment-based lead generation. J Med Chem. 2012;55(7):3285-3306.

44. Fiume L, Manerba M, Vettraino M, Di Stefano G. Impairment of aerobic glycolysis by inhibitors of lactic dehydrogenase hinders the growth of human hepatocellular carcinoma cell lines. Pharmacology. 2010;86(3):157-162.

45. Yang Y, Su D, Zhao L, Zhang D, Xu J, Wan J, Fan S, Chen M. Different effects of LDH-A inhibition by oxamate in non-small cell lung cancer cells. Oncotarget. 2014;5(23):11886-11896.

46. Escudero-Ortiz V, Ramón-López A, Duart MA, Pérez-Ruixo JJ, Valenzuela B. Populational pharmacokinetics of doxorubicin applied to personalised its dosing in cancer patients. Farm Hosp. 2012;36(4):282-291.

47. Spallarossa P, Altieri P, Aloi C, Garibaldi S, Barisione C, Ghigliotti G, Fugazza G, Barsotti A, Brunelli C. Doxorubicin induces senescence or apoptosis in rat neonatal cardiomyocytes by regulating the expression levels of the telomere binding factors 1 and 2. Am J Physiol Heart Cir Physiol. 2009;297:H2169-H2181.

48. Drug information database. http://www.drugs.com/pro/metformin.html. Accessed 25th of November, 2014

49. Koukourakis MI, Kontomanolis E, Giatromanolaki A, Sivridis E, Liberis V. Serum and tissue LDH levels in patients with breast/gynaecological cancer and benign diseases. Gynecol Obstet Invest. 2009;67:162-168.

50. Arora R, Schmitt D, Karanam B, Tan M, Yates C, Dean-Colomb W. Inhibition of the Warburg effect with a natural compound reveals a novel measurement for determining the metastatic potential of breast cancers. Oncotarget. 2015;6(2):662-78

51. Hait WN, Jin S, Yang JM. A matter of life or death (or both): understanding autophagy in cancer. Clin Cancer Res. 2006;12(7):1961-1965.

52. Gump JM, Thorburn A. Autophagy and apoptosis: what is the connection? Trends Cell Biol. 2011;21(7):387-392.

53. Tschan MP, Simon HU. The role of autophagy in anticancer therapy: promises and uncertainties. J Intern Med. 2010;268(5):410-418.

54. Macintosh RL, Ryan KM. Autophagy in tumour cell death. Semin Cancer Biol. 2013;23(5):344-351.

55. Tanida I, Ueno T, Kominami E. LC3 and autophagy. Methods Mol Biol. 2008;445:77-88. 


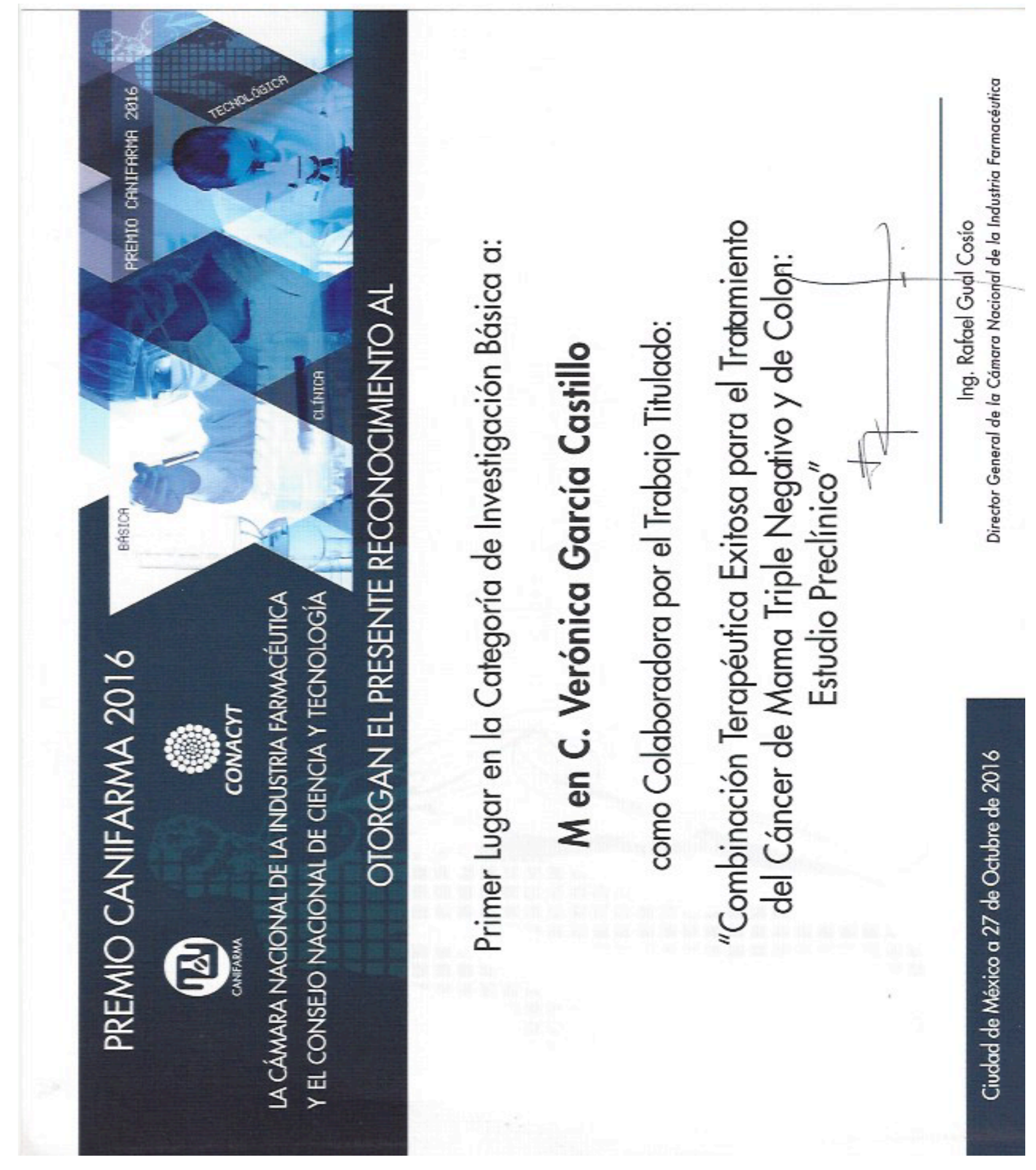




\section{Premio Nacional de Investigación}

\section{5}

gsk

GlaxoSmithKline y Fundación Mexicana para la Salud

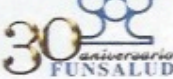
otorgan el presente

\section{Reconocimiento \\ 1er. Lugar \\ Básica}

Título del trabajo:

Fármacos Inhibidores de mTOR Y LDH-A para el tratamiento de cáncer de mama triple negativo: Estudio Preclínico

Investigador principal:

Nadia Judith Zacobo Aerrera

Coinvestigadores:

Carlos Guadalupe Pérez Plasencia

Verónica García Castillo

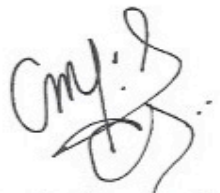

Dra. Ma. Yolanda Cervantes Apolinar

Presidenta Ejecutiva

Premio Nacional de Investigación GSK

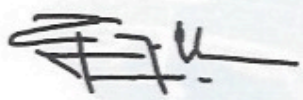

Lic. José Campillo García Presidente Ejecutivo Fundación Mexicana para la Salud 
